UNIVERSIDADE DE SÃO PAULO

INSTITUTO DE FÍSICA, INSTITUTO DE QUÍMICA, INSTITUTO DE BIOCIÊNCIAS E FACULDADE DE EDUCAÇÃO

LUANA DALMASCHIO BIASUTTI

O ENGAJAMENTO MÚTUO COMO ELEMENTO FORMATIVO

DE MEDIADORES EM ESPAÇOS DE EDUCAÇÃO NÃO FORMAL

São Paulo

2014 


\section{O ENGAJAMENTO MÚTUO COMO ELEMENTO FORMATIVO DE MEDIADORES EM ESPAÇOS DE EDUCAÇÃO NÃO FORMAL}

Dissertação de mestrado apresentada ao Instituto de Física, Instituto de Química, Instituto de Biociências e Faculdade de Educação da Universidade de São Paulo para a obtenção do título de Mestre em Ensino de Ciências.

Área de Concentração: Ensino de Biologia

Orientador (a): Alessandra Bizerra

Co-orientador: Mikiya Muramatsu

São Paulo

2014 
Autorizo a reprodução total ou parcial deste trabalho, por qualquer meio convencional ou eletrônico, para fins de estudo e pesquisa, desde que citada a fonte.

FICHA CATALOGRÁFICA

Preparada pelo Serviço de Biblioteca e Informação do Instituto de Física da Universidade de São Paulo

Biasutti, Luana Dalmaschio

O engajamento mútuo como elemento formativo de mediadores em espaços de Educação Não Formal. São Paulo, 2014.

Dissertação (Mestrado) - Universidade de São Paulo. Faculdade de Educação, Instituto de Física, Instituto de Química e Instituto de Biociências.

Orientador: Profa. Dra. Alessandra Bizerra

Área de Concentração: Ensino de Biologia

Unitermos: 1.Biologia ( Estudo e ensino); 2. Educação Não Formal; 3. Comunidades

(Prática); 4. Formação de mediadores; 5. Formação inicial.

USP/IF/SBI-079/2014 
Dedico a meus pais, exemplo de luta e determinação. 


\section{AGRADECIMENTOS}

A Deus pelo dom da vida. A minha mãe a ao meu pai pelo apoio incondicional. Nessa estadia em São Paulo, uma das coisas que mais aprendi a valorizar foram os princípios que meus pais me deram. Sem os meus princípios não conseguiria chegar a lugar algum.

À Prof ${ }^{\mathrm{a}}$. Dr ${ }^{\mathrm{a}}$. Alessandra Bizerra por ter sido muito mais do que uma orientadora, por ter tido paciência, por me guiar nas escolhas, pelas puxadas de orelha, pelos conselhos e por ser fonte de inspiração, pois todos que a conhecem querem ser pelo menos um pouquinho como essa mulher "Bombril"- mãe, esposa, professora, pesquisadora, dentre tantas outras funções que desempenha tão bem.

As minhas irmãs Luziene e Letícia pelo companheirismo e pelo ombro que sempre teve lugar para minhas lamúrias. Aos meus sobrinhos Aline, Roney e Wellington por me trazerem tanta alegria. Ao meu cunhado Roney pelas conversas inspiradoras.

Ao Allan, por ter ficado ao meu lado, acreditando em mim e me motivando para conseguir as coisas que almejo e à sua família, Dona Rosa, Yolanda, Neném, Dalva, Renato, Dona Dirce e Seu Alcir por me receberem tão bem e sempre me incentivarem a prosseguir com minhas escolhas.

Aos meus colegas de trabalho e alunos da ETEC Profa. Dra. Doroti Quiomi Kanashiro Toyohara, pois sem eles não teria sobrevivido à vida em São Paulo e por toda experiência aprendida.

A minha roommate Lorena pelas risadas, pelos choros e por, com certeza, ter tornado minha estadia em São Paulo muito mais fácil.

Ao meu primo Ítalo pelos momentos de apoio em São Paulo.

Ao meu co-orientador Prof. Dr. Mikiya Muramatsu por ter sido o primeiro a abrir as portas para mim em São Paulo e por me tratar como filha.

A Profa. Dra. Cecil Chow Robilotta por me ajudar com algumas partes do texto.

A Profa. Dra. Martha Marandino pelo apoio e conversas.

A todos do grupo Arte e Ciência no Parque e da Coc Licenciatura pela amizade e momentos inesquecíveis.

Aos amigos que fiz no mestrado Maria Clara, Natalia Leporo, Leticia Tenório, Bruna Pozzi, Pércia, Natália Ferreira, Danilo Zanardi, Joaquim, Alisson, Thiago Del Corso, Caio de Castro e aos amigos do Zooenbio que tornaram essa caminhada mais suave. 
E por fim, mas não menos importante, ao Prof. Dr. Laércio Ferracioli que mesmo de longe continua ajudando seus pupilos, seja com conselhos, seja como fonte de inspiração. 
"Quem se arrisca a andar por ares nunca antes respirados ou pensar fora da curva tem grandes chances de encontrar pedras no caminho. No entanto, ninguém é digno de contribuir para a ciência se não usar suas dores e insônias nesse processo." (Augusto Cury, 2014). 


\section{RESUMO}

BIASUTTI, Luana Dalmaschio. O engajamento mútuo como elemento formativo de mediadores em espaços de Educação Não Formal. 2014. 185 f. Dissertação (Mestrado em Ensino de Ciências - Ensino de Biologia) Instituto de Biociências, Instituto de Física, Instituto de Química e Faculdade de Educação da Universidade de São Paulo. São Paulo, 2014.

Nota-se um crescimento constante da importância dos espaços de Educação Não Formal frente ao Ensino de Ciências. Com isso, passa a ser imprescindível a presença de profissionais que promovam a interação da ciência com o público e, consequentemente, a formação dos mesmos para que possam atuar de maneira efetiva no desenvolvimento de atividades educativas nesses locais. Nesta perspectiva, este estudo de caso teve por finalidade analisar o processo de formação de mediadores de um espaço de Educação Não Formal de ciências, utilizando a perspectiva da teoria de Comunidades de Prática, elaborada por Jean Lave e Etienne Wenger. Mais especificamente, teve como objetivo analisar como o elemento engajamento mútuo, proposto pelos autores como um dos pontos fundamentais da participação dos membros de uma comunidade de prática, pode contribuir para a formação inicial de mediadores. Para realização dessa investigação, foi necessário, primeiramente, averiguar se o local de estudo escolhido - Estação Biologia (EB), projeto de extensão universitária vinculado ao Instituto de Biociências da Universidade de São Paulo, poderia ser considerado uma comunidade de prática, sendo necessária, para isso, a identificação de três elementos básicos: o repertório compartilhado, o engajamento mútuo e o empreendimento conjunto. Os dados coletados a partir de análises documentais, entrevistas gravadas semiestruturadas, filmagens e observações de visitas evidenciam que os três elementos básicos coexistem na EB, podendo, assim, ser considerada uma comunidade de prática. Nessa comunidade, às possibilidades de flexibilização de funções e o estabelecimento de negociações internas promovem o aumento do engajamento mútuo que está diretamente envolvido com a transformação de um mediador periférico em um mediador central, e consequentemente, com a sua formação tanto para atuar como mediador, quanto para atuar profissionalmente, seja na carreira de bacharelado ou de licenciatura. Isso pode ser afirmado visto que, ao aumentar o engajamento na prática da comunidade, esse mediador se apropria de conhecimentos que poderão ser usados dentro e fora da EB.

Palavras-chave: comunidade de prática, engajamento mútuo, formação de mediador, Educação Não Formal. 


\begin{abstract}
BIASUTTI, Luana Dalmaschio. The mutual engagement as a formative element of mediators in spaces of non-formal education. 2014. 185 f. Dissertation (Master of Science Education - Biology Education) Institute of Biosciences, Institute of Physics, Institute of Chemistry and School of Education of University of São Paulo. São Paulo, 2014.
\end{abstract}

There has been a steadily growing role of non-formal education within science teaching. Thus, the presence of professionals is crucial for promoting the interaction of science with the public. Consequently, the formation of these professionals is essential to enable them to act effectively in the development of activities at educational sites. Accordingly, this case study aims at examining the process of formation of mediators in the area of non-formal education in science, using the Theory of Community of Practice, coined by Jean Lave and Etienne Wenger. More specifically, the analysis of the mutual engagement element, as proposed by the authors as one of the key points in the participation of members in a community of practice, may contribute to the initial training of mediators. To undertake this study, it was necessary to first determine whether the chosen place of study, Estação Biologia (EB) of the University of São Paulo, could be considered a community of practice. For this, the identification of three basic elements were required: shared repertoire, mutual engagement and joint enterprise. The data that were collected from documentary analysis, semi-structured registered interviews, recorded visits and personal observations, showed that all the three basic elements were present in EB, and thus it can be considered a community of practice. In this community, the flexibility of functions, and the establishment of internal negotiations, promote increased mutual engagement that is directly involved in the transformation of a peripheral into a central mediator, and consequently, their training both to act as a mediator and how to do so professionally. Considering that by increasing engagement in the practice of community, this mediator appropriates knowledge that can be used inside and outside the EB.

Keywords: community of practice, mutual engagement, mediator training, non-formal education. 


\section{LISTA DE FIGURAS}

Figura 01. Componentes da uma teoria social da aprendizagem ........................................ 25

Figura 02. Dimensões da prática como propriedade de uma comunidade .............................. 29

Figura 03. Sala da EB, auditório 4, do prédio Félix Kurt Rawitscher .................................... 39

Figura 04. Jardim do departamento de botânica - Sobre as Ondas ......................................... 39

Figura 05. Interações entre membros de uma COP ............................................................ 51

Figura 06. Gestos usados pelos mediadores como evidência do repertório compartilhado pela

$\mathrm{EB}$

\section{LISTA DE TABELAS}

Tabela 01. Critérios utilizados para definição dos contextos educacionais. ............................ 17

Tabela 02. Comparação entre COP e outras estruturas organizacionais ................................. 28

Tabela 03. Evidências encontradas nos dados coletados que justificam a EB ser considerada uma COP

\section{SUMÁRIO}

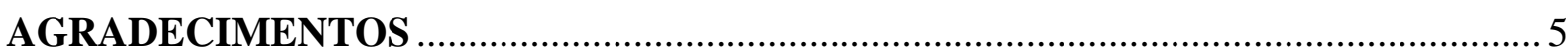

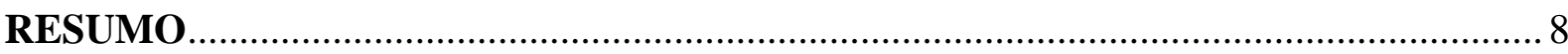

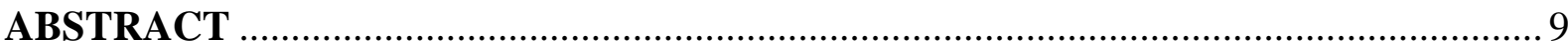

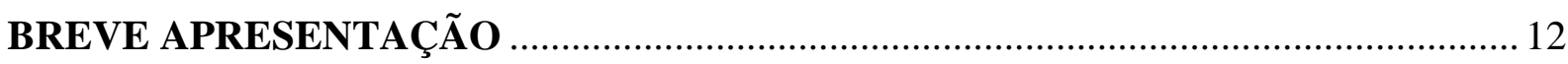

Capítulo 1. A formação de mediadores de espaços de Educação Não Formal ................. 15

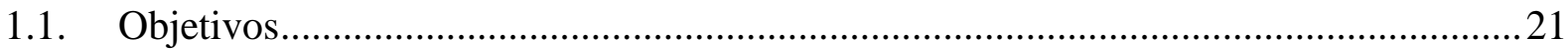

Capítulo 2. A Teoria de Comunidades de Prática: elementos e aplicações...................... 22

2.1. Teoria social de aprendizagem - Aprendizagem situada ............................................ 23

2.2. Participação Periférica Legitimada........................................................................... 25

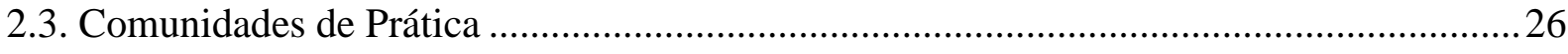

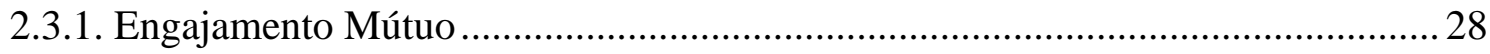

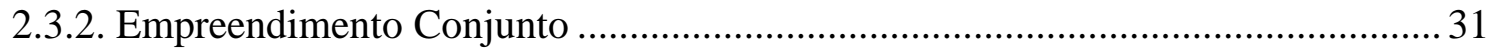

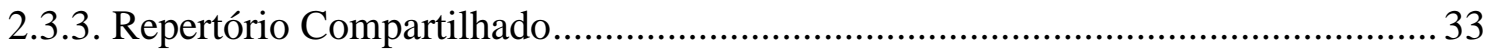

2.4. As Comunidades de Prática em Espaços de Educação Não Formal ................................. 33

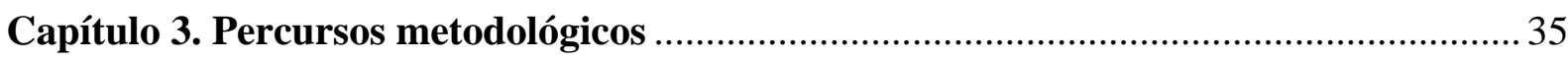




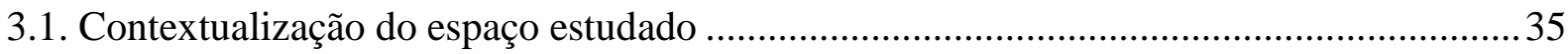

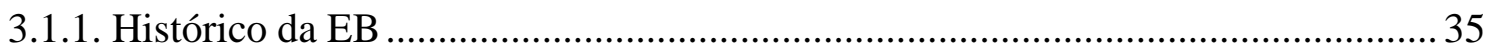

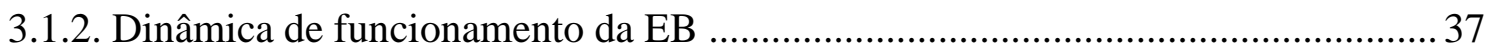

3.1.3. Caracterização da EB como espaço de Educação Não Formal ............................. 41

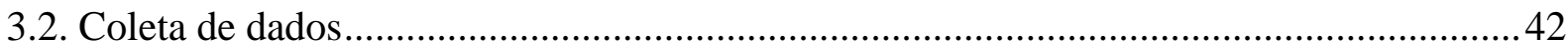

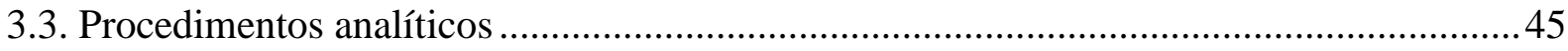

Capítulo 4. Caracterização da Estação Biologia como uma Comunidade de Prática...... 47

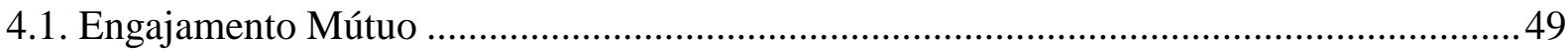

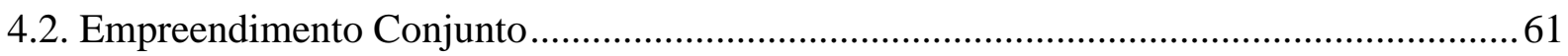

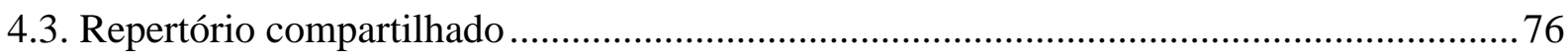

Capítulo 5. O Engajamento Mútuo como Elemento Formativo de Mediadores .............. 83

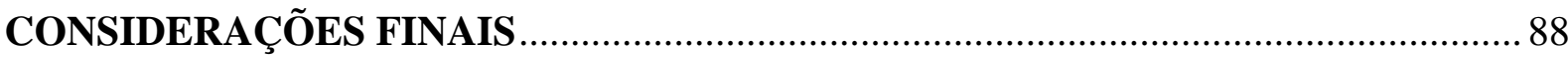

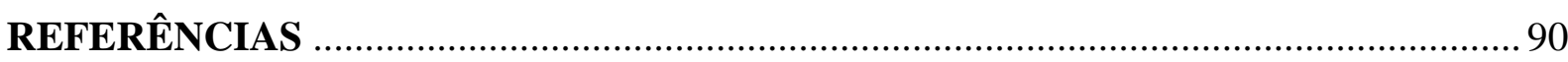

ANEXO A - Transcrições das Entrevistas com os Mediadores ........................................ 95

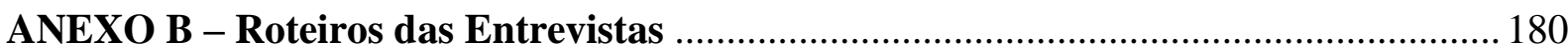

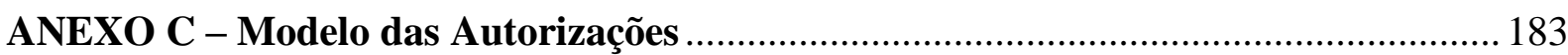




\section{BREVE APRESENTAÇÃO}

Sou formada em bacharelado e em licenciatura plena em Ciências Biológicas pela Universidade Federal do Espírito Santo (UFES), meu Estado natal. Sempre tive interesse por ciências e biologia e comecei minha graduação no segundo semestre de 2005. Antes de entrar na graduação, teci uma série de sonhos, como, por exemplo, trabalhar com grandes mamíferos ou virar geneticista, e não percebi a priori que a universidade me ofereceria muitos outros campos para pesquisar. Quando comecei a cursar as disciplinas, notei que me interessava mais pelas disciplinas de botânica do que pelas de zoologia.

No segundo semestre, tive uma disciplina, chamada Taxonomia de Plantas Avasculares, ministrada por uma excelente professora - $\operatorname{Prof}^{\mathrm{a}}$. Dr ${ }^{\mathrm{a}}$. Valéria Fernandes, que é ecóloga de algas continentais. Nesta disciplina, ela abordava grupos de plantas que não possuem vasos condutores e também grupos que nem são do reino das plantas, como alguns protistas e fungos. A matéria foi superinteressante, mas a parte que mais me chamou atenção foi a dos fungos. Os aspectos abordados sobre esse grupo de seres me entusiasmaram e me inspiraram de tal forma que quis me especializar nessa área. Viraria então uma micóloga (especialista que estuda fungos).

Acontece que nem tudo na vida de um pesquisador são flores e passei por vários empecilhos, como o fato de não existir um especialista em fungos de vida livre na UFES e ninguém disposto a me orientar nessa área. Para não dizer que não encontrei ninguém, tive ajuda e estímulo de um professor da Universidade de Taubaté, Prof. Dr. Júlio César Voltolini, o qual ficou sabendo desse meu interesse por fungos em um curso de ecologia de campo que ele ministrou na UFES e do qual eu participei. Ele se disponibilizou a me coorientar à distância, mas não deu certo, primeiro pela falta de um orientador vinculado a UFES para solicitar bolsa de iniciação científica a algum órgão de fomento para arcar com as despesas da pesquisa e, segundo, pela própria distância.

Depois do prof. Voltolini, tive uma experiência de trabalho com a $\operatorname{Prof}^{\mathrm{a}}$. $\operatorname{Dr}^{\mathrm{a}}$. Andrea Ghelfi, que é engenharia agrônoma e que estava como professora contratada de microbiologia na UFES. Desenvolvemos um projeto sobre isolamento de linhagens fúngicas do rio Aribiri, Vitória/ES, com potencial para biorremediação de metais pesados, o qual me rendeu uma apresentação de pôster no $24^{\circ}$ Congresso Brasileiro de Microbiologia, em Brasília. Este trabalho só durou um semestre e teve sua finalização motivada na falta de recursos para pagar as despesas da pesquisa e porque a prof ${ }^{\mathrm{a}}$. Andrea conseguiu uma bolsa de pós-doutorado que inviabilizou a continuação da pesquisa. 
Nesse meio tempo, fui cursando várias disciplinas interessantes, entre elas as de licenciatura. Dentro de mim já despontava certo interesse em dar aula, mas não o suficiente para retirar o preconceito que eu tinha em ser professora. Pensava que era uma profissão pouco valorizada e, como minha mãe tinha sido chefe de secretaria, já sabia de certa forma os problemas enfrentados por este profissional.

Em março de 2008, surgiu a oportunidade de trabalhar no ModeLab - Laboratório de Tecnologias Interativas Aplicadas à Modelagem Cognitiva, cujo professor responsável era Prof. Dr. Laércio Ferracioli. Eles precisavam de um graduando em biologia para trabalhar com utilização da modelagem computacional no ensino de ciências. No começo, fiquei um pouco apreensiva por se tratar de um laboratório do Departamento de Física, mas achei o projeto tão interessante que resolvi encarar o desafio.

Essa oportunidade foi o "pontapé inicial" para começar a me interessar realmente pela área de Ensino de Ciências. O prof. Laércio sempre me auxiliou nessas escolhas e sempre me deu ótimos conselhos referentes aos percursos de uma vida acadêmica. Além disso, participei de um curso de formação de professores oferecido pelo laboratório, também participei de alguns congressos, seminários e encontros relevantes para essa minha formação, como o XVIII Simpósio Nacional de Ensino de Física (SNEF), $1^{a}$ Conferência Estadual de Ciência, Tecnologia e Inovação, $4^{a}$ Conferência Regional Sudeste de Ciência, Tecnologia e Inovação, e o principal deles, a XI Reunião da RedPop - Rede de Popularização da Ciência e da Tecnologia na América Latina e Caribe, que aconteceu em maio de 2009, em Montevidéu, Uruguai. Digo que esse encontro foi o principal, porque foi a partir dele que decidi o que gostaria de pesquisar no mestrado: espaços de Educação Não Formal, mais especificamente Museus e Centros de Ciências. Fui para o Uruguai com minha amiga de laboratório que também ajudou muito na produção da minha monografia e em outros trabalhos produzidos na graduação, Mara Hombre Mulinari, para apresentarmos o trabalho Portal Sociedade das Águas: Popularização e Divulgação da Ciência Através da Formação Continuada de Professores.

O Sociedade das Águas (www.sociedadedasaguas.org) é um portal de Formação Continuada de Professores em Serviço e que, também, tem por finalidade divulgar e popularizar a ciência, tecnologia e inovação a partir do tema gerador Água e da utilização dos conceitos de modelos, modelagem e modelagem computacional e simulação. Na criação deste ambiente, colaborei produzindo materiais relacionados ao tema gerador, como o texto sobre o 
Aquífero Guarani e o Módulo Educacional sobre o Ciclo da Água, sendo este último fruto da minha monografia.

Em julho de 2009, comecei a trabalhar numa escola de reforço chamada Centro Individualizado de Aprendizagem (CIA), onde fui monitora de ciências e biologia por um ano. Neste local, tive a oportunidade de ver que realmente era professora o que queria ser. Ter contato com alunos do ensino médio e, principalmente, do ensino fundamental me fizeram enxergar a paixão pela área do ensino. Juntando essa experiência com a vivenciada na reunião da RedPop tive a certeza de que era com ensino de ciências que gostaria de lidar no meu mestrado e escolhi a USP por se tratar de uma universidade de renome e pela existência de uma linha de pesquisa cuja abordagem são os espaços não formais de educação. 


\section{Capítulo 1. A formação de mediadores de espaços de Educação Não Formal}

Devido às intensas mudanças científicas e tecnológicas do pós-guerra, estendidas até os dias de hoje e fortalecedoras da chamada Sociedade do Conhecimento, vê-se uma constante demanda para que os indivíduos se mantenham "atualizados". Nesta perspectiva, o ensino de ciências tem um papel fundamental. Mas, de fato, a função do ensino de ciências vai além da atualização e informação, abrangendo também a formação de cidadãos alfabetizados cientificamente, com habilidade de opinar de forma crítica sobre os procedimentos e resultados de pesquisas científicas e sobre as consequências que essas podem trazer para a população. Segundo Moreira (2004), o ensino de ciências tem por objetivo promover a compreensão de conceitos científicos a fim de que os sujeitos consigam interpretar o mundo pelo viés da ciência, manejando conceitos, leis e teorias científicas e identificando aspectos históricos, epistemológicos, sociais e culturais da ciência.

$\mathrm{O}$ ensino de ciências e, consequentemente, a alfabetização científica tem tido as escolas como contexto predominante (AFONSO et al., 2011; SASSERON, 2008; TEIXEIRA, 2007; KRASILCHIK, 2000), contudo, não estão restritos a estas. Existem vários trabalhos, como de Cascais e Terán (2011), Marandino (2008), Rocha (2008), Queiróz et al. (2002) e Valente (2005), entre tantos outros, que defendem os espaços de Educação Não Formal como locais significativos no processo de educação científica. Rocha (2008), inclusive, argumenta que a escola não é capaz de promover a alfabetização científica sozinha, já que a quantidade de informação é cada vez maior, sendo necessária uma parceria com outros espaços educativos, como os de Educação Não Formal.

A Educação Não Formal pode ser definida em perspectivas diversificadas, por diferentes autores ${ }^{1}$. Nesta investigação, serão emprestadas as visões de Gohn (2006) e Marandino et al. (2008) por se aproximarem das concepções aqui expostas. Assume-se a Educação Não Formal como aquela que ocorre "via os processos de compartilhamento de experiências, principalmente em espaços e ações coletivas cotidianas" (GOHN, 2006, p.28).

Neste sentido, Gohn (2006) defende a Educação Formal como aquela desenvolvida nas escolas, instituições organizadas por diretrizes e parâmetros curriculares nacionais, onde o educador é o professor. Nesses locais as regras e os padrões comportamentais são definidos previamente, assim como os conteúdos que serão ministrados. Os alunos são separados por

\footnotetext{
${ }^{1}$ A distinção e as definições de espaços de Educação Não Formal não são focos desta investigação. Sugere-se aos interessados neste tópico a leitura de Smith (1996).
} 
idade, classe de conhecimento e recebem uma certificação ou uma titulação ao final do processo.

Já a Educação Informal é aquela em que os indivíduos vivenciam durante o processo de socialização, no qual os agentes educadores são os familiares, amigos, vizinhos, entre outros. Sendo assim, ela acontece de maneira espontânea na residência do indivíduo, no bairro, na igreja, enfim, nos locais em que este frequenta.

A Educação Não Formal acontece em espaços como museus, centros de ciência, zoológicos, jardins botânicos, ONGs. Nesses locais, as atividades desenvolvidas possuem intencionalidade educativa e são realizáveis em um curto prazo; o público visitante não passa, necessariamente, por processo avaliativo ou recebe certificação; o controle é interno e democrático; a intencionalidade é centrada no aprendiz; as atividades são semiestruturadas e pode-se dizer que possui uma proposta curricular, porém, determinada internamente.

Uma definição complementar é apresentada na tabela 01 a seguir, elaborada por Marandino et al. (2008), que leva em consideração a ideia de continuum apresentada por Rogers (2004) e os diversos critérios utilizados por pesquisadores, educadores e outros profissionais ligados às áreas de Ensino de Ciências e divulgação científica para refletir sobre as definições dadas aos contextos de educação.

Tabela 01. Critérios utilizados para definição dos contextos educacionais.

Extraída de Marandino et al., 2008a, p.15.

\begin{tabular}{|ccc|}
\hline & Contextos Educacionais & \\
\hline Formal $\langle\langle\langle\langle\langle$ Não Formal $\rangle\rangle\rangle$ & \rangle Informal \\
\hline Propósitos & $\begin{array}{c}\text { Geral, com } \\
\text { certificação. }\end{array}$ & $\begin{array}{c}\text { Específico, sem necessidade } \\
\text { de certificação. }\end{array}$ \\
\hline $\begin{array}{c}\text { Organização do } \\
\text { Conhecimento }\end{array}$ & $\begin{array}{c}\text { Padronizada, } \\
\text { acadêmica. }\end{array}$ & Individualizada, prática. \\
\hline Tempo & $\begin{array}{c}\text { Longo prazo, contínuo, } \\
\text { sequencial. }\end{array}$ & Curto prazo, tempo parcial. \\
\hline Estrutura & $\begin{array}{c}\text { Altamente estruturada, } \\
\text { currículo definido, } \\
\text { atividade determina perfil } \\
\text { do aprendiz, baseada na } \\
\text { instituição, avaliativa. }\end{array}$ & $\begin{array}{c}\text { Flexível, ausência de } \\
\text { currículo, aprendiz } \\
\text { determina perfil da } \\
\text { atividade, relacionada à } \\
\text { comunidade, não avaliativa. }\end{array}$ \\
\hline Controle & Externo, hierárquico. & Interno, democrático. \\
\hline Intencionalidade & Centrada no educador. & Centrada no aprendiz. \\
\hline
\end{tabular}

A partir das reflexões apresentadas pelas autoras é possível perceber que as categorizações dos espaços educativos não deveriam ser consideradas estanques, haja vista a enormidade de inter-relações entre os diferentes contextos educacionais. Entretanto, apesar de 
ser possível entender esses diferentes contextos como processos educativos interligados/contínuos, observa-se que há características próprias de cada um deles.

Assim, definindo-se a intencionalidade educativa desses espaços de Educação Não Formal e evidenciando-os como locais significativos no processo de alfabetização científica, vale salientar o importante papel dos agentes educadores destes locais, os mediadores ${ }^{2}$. Esses profissionais possuem o importante papel de propiciadores da interação entre a ciência e o público visitante, nos seus aspectos científico, cultural e social (CAZELLI et al., 2003). Os mediadores se tornam fundamentais, portanto, na concretização da comunicação entre instituição e público, dando significado às questões presentes no local (MARANDINO et al., 2008).

Devido a essa importância e as características singulares dos espaços de Educação Não Formal, torna-se imprescindível refletir sobre a formação desses educadores. Referente a essa temática, sabe-se que alguns museus de ciência no Brasil, como o Museu da Vida (FIOCRUZ), a Estação Ciência (USP) e o Museu de Astronomia e Ciências Afins (MCTI), realizam cursos de formação de mediadores (MARANDINO, et al., 2003).

Apesar disso, poucos são os trabalhos que efetivamente abordam o processo de formação desses educadores, como o de Barros (2002), Queiróz et al. (2002) e Marandino (2008).

No trabalho de Barros (2002), a autora elucida a importância desse processo formativo, já que os mediadores são elo entre a exposição e o público, considerando-o uma tarefa árdua merecedora de constante aprimoramento. Barros chama a atenção para o complicado fato de os mediadores dos museus e centros de ciência serem pessoas com vínculo transitório, as quais muitas vezes são selecionadas para atuar em determinadas exposições temporárias ou itinerantes, sem uma devida continuidade. A autora questiona quem são os mediadores desses espaços e como eles são preparados. Além disso, aspectos que devem aparecer na preparação dos mediadores são citados, como ter um conhecimento bem fundamentado do conteúdo científico presente na exposição, saber fazer a adaptação entre a linguagem do cotidiano e a científica, compreender a operação dos aparelhos presentes na exposição, conhecer aspectos históricos, evolução de ideias, mitos referentes ao tema

\footnotetext{
${ }^{2}$ Sabendo-se dos diferentes termos que podem ser empregados ao profissional que promove a interação da exposição com o público em um espaço de Educação Não Formal, como guia, monitor, facilitador, entre outros (MASSARANI; ALMEIDA, 2008), faz-se necessário explicitar que nesse trabalho o termo utilizado será mediador.
} 
proposto na exposição, ter noção de psicodidática aplicada à aprendizagem da ciência, desenvolver sensibilidade para saber lidar com os diferentes públicos.

No trabalho de Queiróz e colaboradores (2002), é considerado que "a mediação requer um saber com dimensões peculiares: o saber da mediação" (QUEIRÓZ et al., 2002, p.2). Para explicar esse "saber da mediação", os autores aproximam a formação de professores de espaços formais com a formação de mediadores de espaços não formais, evidenciando a importância da prática, da experiência e do lado artístico desses profissionais para interagir com os diferentes públicos e com possíveis improvisações necessárias devido às diversas situações vivenciadas nesses locais. Duas mediadoras do Museu de Astronomia e Ciências Afins (MAST/MCTI) foram acompanhadas para se tentar identificar os saberes da mediação. Alguns desses saberes foram apontados, pelos autores, como saberes compartilhados com o ambiente escolar, como:

- Saber disciplinar: referente ao conhecimento do conteúdo de ciências pertinente à exposição;

- Saber da transposição didática: saber transformar o modelo pedagógico para torna-lo acessível ao público;

- Saber do diálogo: saber estabelecer relação com o público, valorizando suas concepções prévias, sabendo formular questões pertinentes à discussão do tema em questão e dando tempo para o visitante expor suas ideias;

- Saber da linguagem: saber adequar a linguagem aos diferentes públicos;

- Saber da história da ciência: conhecer o conteúdo da história da ciência, comparando-a e distinguindo-a do conteúdo da história vigente;

- Saber da visão de ciência: saber aspectos da ciência que dizem respeito à origem, aos processos de construção e ao status do conhecimento científico;

- Saber das concepções alternativas: conhecer concepções alternativas sobre determinados assuntos e saber explorá-las durante a visita.

Outros saberes foram identificados como saberes próprios da mediação museal, como:

- Saber da história da instituição: saber a história da instituição onde está localizada a exposição;

- Saber da interação com professores: saber lidar com os professores que acompanham os alunos durante a visita;

- Saber da conexão: saber conectar diferentes partes da exposição; 
- Saber da história da humanidade: saber situar a temática da exposição num contexto histórico-social mais amplo;

- Saber da expressão corporal: saber usar o próprio corpo e fazer os visitantes usarem os próprios corpos para explicar fenômenos científicos apresentados na exposição;

- Saber da manipulação: saber dar liberdade aos visitantes para usarem os aparatos da exposição e, quando necessário, propor formas de uso;

- Saber da ambientação: saber dos aspectos ambientais das exposições, tais como luz, cor, estilo do mobiliário, etc.;

- Saber da concepção da exposição: saber a tendência pedagógica das pessoas que idealizaram a exposição.

Apesar do trabalho de Queiróz et al. (2002) ressaltar a especificidade dos saberes que estão presentes no processo de mediação em espaços de Educação Não Formal, percebe-se que alguns daqueles elencados como próprios da mediação museal também são detectáveis em instituições formais, tais como saber da história da humanidade e saber da expressão corporal. Neste sentido, o professor também saberia situar a temática do conteúdo num contexto histórico-social mais amplo e usar o próprio corpo para explicar fenômenos científicos. Além disso, entende-se o saber dito como expressão corporal como algo mais amplo do que somente a utilização do corpo para explicar determinados fenômenos. A interpretação das expressões corporais do aluno pode ser uma estratégia utilizada pelo professor para identificar, por exemplo, o interesse do aluno sobre o conteúdo ministrado e se o aluno entendeu ou não tal assunto. Além disso, os gestos expressos em um processo interativo também são importantes para a construção de significados (PECCININNI; MARTINS, 2004).

Em suma, os estudos de Barros (2002) e de Queiróz et al. (2002) trazem saberes necessários de serem desenvolvidos no processo de formação dos mediadores. Em complemento a isso, o trabalho de Marandino (2008), elucida a importância da formação dos mediadores para que a mediação tenha características de uma discussão dirigida ou uma visita-descoberta ao invés de uma visita-palestra. Além disso, a formação é essencial para que o discurso real, elaborado pelos mediadores, se aproxime do discurso pretendido, idealizado pela instituição. A autora aponta diferentes tipos de modelos de formação de mediadores, ressaltando que tais modelos não são excludentes. Esses modelos podem ser:

- Centrado no conteúdo específico: nessa formação a ênfase é dada ao conteúdo específico relacionado à exposição. 
- Centrado na prática: não há formação prévia. A ação da mediação é aprendida durante a prática.

- Centrado na relação aprendiz-mestre: nesse tipo de formação, os mediadores novos aprendem observando os mediadores mais experientes.

- Centrado na auto formação: o mediador utiliza de suas experiências, leituras e de seu conhecimento para elaborar estratégias de ação.

- Centrado na educação e comunicação: a formação, neste caso, enfatiza aspectos teóricos e práticos da educação, aprendizagem e comunicação.

Observa-se que esses modelos são divididos de acordo com a estratégia de formação dos mediadores e que esta pode ou não determinar explicitamente quais saberes serão trabalhados durante o processo. Neste caso, por exemplo, no modelo centrado no conteúdo específico, provavelmente serão desenvolvidos saberes relacionados ao conteúdo, como o disciplinar, a história da ciência, entre outros. No modelo centrado na educação e comunicação, terão destaque os saberes relacionados com a parte pedagógica, como os saberes de interação com o público, o saber da transposição didática, entre outros. Já, nos modelos centrados na prática, na relação aprendiz-mestre e na auto formação não fica explícito quais saberes são enfatizados, podendo variar de acordo com a identidade da instituição que emprega tais modelos.

Nota-se assim, frente à literatura analisada, que a formação de mediadores é uma preocupação vigente. Nesse contexto, e como forma de contribuir para uma área de pesquisa em crescimento, este trabalho visa analisar o processo de formação de mediadores de um espaço de Educação Não Formal em ciências. Traz como elemento de contribuição o referencial da teoria de Comunidade de Prática, cunhada por Jean Lave e Etienne Wenger. Pretende-se investigar como o estudo do elemento engajamento mútuo, proposto pelos autores como um dos pontos fundamentais da participação e identidade dos membros de uma Comunidade de Prática, pode contribuir para a formação inicial de mediadores.

Entretanto, nesta perspectiva, primeiramente, é necessário averiguar se grupos de mediadores de espaços de Educação Não Formal podem se constituir como uma Comunidade de Prática, sendo necessária, para isso, a identificação de três elementos básicos: o repertório compartilhado, o engajamento mútuo e o empreendimento conjunto. 


\subsection{Objetivos}

Os objetivos desse estudo são:

- Verificar se a Estação Biologia pode ser considerada uma Comunidade de Prática, buscando identificar a presença dos elementos engajamento mútuo, empreendimento conjunto e repertório compartilhado.

- Compreender como o engajamento mútuo, um dos elementos constituintes das comunidades de prática relacionados à participação e à identidade dos respectivos membros, pode contribuir para a formação inicial de mediadores de espaços de Educação Não Formal.

Para responder às questões acima, essa dissertação foi organizada da seguinte maneira: Capítulo 2: A Teoria de Comunidades de Prática: elementos e aplicações. Neste capítulo, será apresentado o referencial teórico utilizado nessa pesquisa, falando-se um pouco dos criadores - Jean Lave e Etienne Wenger - e da teoria de aprendizagem social que deu início ao conceito de COP. Além disso, serão apresentados os elementos chaves e as dimensões que podem ser utilizados para definir uma COP. Capítulo 3. Percursos metodológicos. Neste capítulo, o local de estudo escolhido será contextualizado quanto ao seu histórico, à sua dinâmica de funcionamento e às características presentes neste espaço que permitem considerá-lo como um espaço de Educação Não Formal. Também serão apresentadas as técnicas escolhidas para coleta de dados e os procedimentos analíticos. Capítulo 4. Caracterização da EB como uma COP. Neste capítulo, serão mostradas as evidências encontradas para se considerar a EB como uma COP. Para isso, os dados que elucidam as dimensões - engajamento mútuo, empreendimento conjunto e repertório compartilhado serão analisados separadamente. E, por fim, no Capítulo 5. O Engajamento Mútuo como Elemento Formativo de Mediadores serão mostradas algumas situações que acontecem na EB que promovem o engajamento mútuo e como esse elemento ajuda na formação inicial do mediador para a sua atuação dentro e fora da EB. 


\section{Capítulo 2. A Teoria de Comunidades de Prática: elementos e aplicações}

Este capítulo aborda um breve histórico dos criadores do termo Comunidade de Prática (COP), a teoria de aprendizagem social que deu início ao conceito e os elementos constituintes que definem uma $\mathrm{COP}^{3}$.

A Teoria de Comunidade de Prática (COP), elaborada por Lave e Wenger (1991), tem sido muito utilizada em empresas, organizações, governos, associações, educação, setores filantrópicos, entre outros (WENGER, 2006).

Jean Lave é doutora em antropologia social pela Universidade de Harvard e professora de educação e geografia na Universidade da Califórnia, Berkeley. Defende a teoria da prática social, na qual acredita que a aprendizagem acontece pela socialização do indivíduo, chamada de aprendizagem situada. Autores como John Dewey, Vigotski, Piaget e Bandura influenciaram e influenciam o trabalho de Lave. Etienne Wenger é doutor em Informação e Ciência da Computação pela Universidade da Califórnia, em Irvine, e também investiga a teoria social da aprendizagem. Ultimamente, auxilia organizações a implementarem a ideia de Comunidades de Prática, ministrando palestras e workshops. Os dois trabalharam juntos na década de 1980, no grupo Prática do Trabalho e Tecnologia do Instituto de Pesquisa em Aprendizagem (IRL, sigla em inglês) do Centro de Pesquisa da Xerox Palo Alto, nos Estados Unidos. Juntos, também, publicaram o livro Situated Learning: Legitimate Peripheral Participation (1991), quando cunharam o termo Comunidades de Prática.

Comunidade de Prática é definida por esses autores como um grupo de pessoas que compartilha uma preocupação ou uma paixão por algo que fazem e juntos aprendem como fazer isso melhor (WENGER, 2006). Essa ideia tem sido aplicada em diversos domínios por ser visto como uma estratégia de gestão de conhecimento.

Para entender melhor as ideias desses autores, primeiramente será feita uma explanação da teoria social que deu origem ao termo Comunidades de Prática, a teoria da aprendizagem situada.

\footnotetext{
${ }^{3}$ Não foi intenção deste trabalho abordar todos os conceitos e conflitos relacionados à teoria de COP, apenas buscou-se explanar os elementos chaves que serão utilizados para responder os objetivos dessa pesquisa. Para tal sugerem-se as leituras da tese da Mônaco (2013) e do artigo de Cox (2005).
} 


\subsection{Teoria social de aprendizagem - Aprendizagem situada}

A teoria social de aprendizagem defendida por Lave e Wenger (1991) é baseada na ideia de que a aprendizagem não está limitada ao aspecto individual. Os autores argumentam que a aprendizagem ocorre no contexto das experiências vividas durante a participação no mundo, ou seja, é um fenômeno fundamentalmente social. Por ter contexto, essa teoria é chamada de aprendizagem situada.

Wenger (1998) propõe quatro premissas importantes sobre a aprendizagem:

1. Seres sociais: sermos seres sociais é um aspecto central da aprendizagem.

2. Competência: conhecimento é uma questão de competência no que se refere a executar coisas, como cantar em sintonia, descobrir um fato científico, escrever poesia, entre outros.

3. Engajamento ativo: o saber é uma questão de engajamento ativo no mundo, ou seja, é uma questão de busca pelas competências mencionadas na segunda premissa.

4. Busca de significados: a busca de significados refere-se à capacidade do ser humano de interagir com o mundo e ao seu engajamento para tornar essa experiência significativa, a ponto de produzir algo.

Essas premissas dão foco à teoria defendida por Wenger de que a aprendizagem tratase de participação social e acontece durante parte integral de nossas vidas, não somente nas escolas. Essa participação social que gera aprendizagem não é apenas o evento de se engajar em certas atividades com certas pessoas, mas é um processo no qual os participantes formam comunidades e constroem identidades em relação à mesma (WENGER, 1998). Ela não se limita ao fazer, abrange, também, quem são os participantes e como eles interpretam o que fazem.

Componentes como o significado, a prática, a comunidade e a identidade, representados na Figura 01, são necessários para caracterizar a participação social como processo de aprendizagem. 


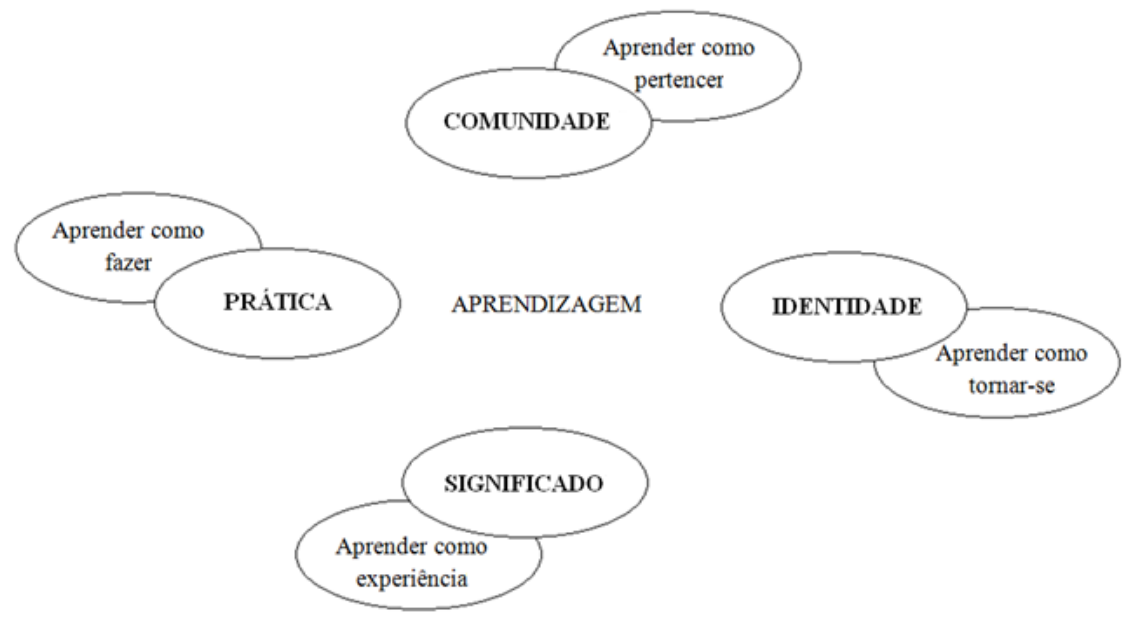

Figura 01. Componentes da uma teoria social da aprendizagem (WENGER, 1998, p.5).

Wenger (1998) analisa esses componentes da seguinte forma:

1. Significado é o aprender como experiência. Esse termo faz referência à capacidade humana, individual e coletiva, de experimentar a vida e o mundo de modo significativo.

2. Prática é o aprender como fazer. Trata-se do histórico compartilhado e dos recursos sociais, estruturas e perspectivas que podem sustentar o engajamento mútuo.

3. Comunidade é o aprender como pertencer. Caracteriza-se como uma configuração social na qual os empreendimentos são definidos e a participação é reconhecida como competência.

4. Identidade é o aprender como tornar-se. Refere-se a como a aprendizagem pode mudar os participantes e criar histórias pessoais que farão parte do contexto da comunidade.

Além dessa definição social para aprendizagem, Lave e Wenger (1991) tratam a relação da aprendizagem com a situação social onde ela acontece como "aprendizagem situada" (situated learning). Nessa perspectiva, eles não estão preocupados com os tipos de processos cognitivos e estruturas conceituais envolvidos no processo de aprendizagem, mas estão interessados nos tipos de engajamentos sociais que fornecem um contexto adequado para a ocorrência da aprendizagem.

Além disso, os autores consideram alunos como aprendizes e professores como mestres/expertises. Comparam, ainda, a aprendizagem que acontece nas escolas com aquela que ocorre, por exemplo, em comunidades de alfaiates, onde os mais novos/inexperientes aprendem uma habilidade com os mais velhos/experientes. A relação entre novatos e veteranos e os modos como esses novatos integram-se a uma Comunidade de Prática são 
explicados pela "participação periférica legitimada" (LPP - Legitimate Peripheral Participation).

\subsection{Participação Periférica Legitimada}

A LPP é um conceito central na teoria da aprendizagem situada de Lave e Wenger. Nesse processo, "as intenções de uma pessoa estão envolvidas e o significado da aprendizagem é configurado através do processo de se tornar um participante ativo na prática sociocultural.” (LAVE e WENGER ${ }^{4}, 1991$, p.29). A LPP é proposta como um descritor de engajamento na prática social que implica a aprendizagem como um constituinte integral (Ibid).

Lave e Wenger (1991) argumentam que cada componente desse termo - participação, periferia e legitimação - não pode ser considerado separadamente, evitando-se a decomposição em legitimado versus ilegitimado, periférico versus central e participação versus não participação. Os autores propõem que o termo seja visto como um todo.

Sendo assim, sugerem que a legitimidade da participação define as características do pertencimento a uma comunidade e, portanto, não se constitui somente como uma condição central para aprendizagem, como passa a ser um elemento constitutivo desta. A "periferialidade" (tradução nossa para peripherality) sugere que existem múltiplas formas de se estar localizado em áreas de participação definidas por uma comunidade e que as mudanças de posição fazem parte da trajetória de aprendizagem dos participantes de tais comunidades.

Além disso, a periferialidade legitimada envolve relações de poder. Em um lugar em que a participação é intensa, a periferialidade é uma posição de empoderamento, contudo, se o lugar impede uma participação mais completa, ela se torna uma posição de desempoderamento. Ela pode ser uma posição de articulação entre comunidades relacionadas e, nesse caso, pode ser fonte de poder ou de impotência, ao conceder ou impedir o intercâmbio entre as comunidades. A periferialidade sugere uma forma de ganhar acesso ao repertório da comunidade, através do envolvimento crescente do aprendiz.

De acordo com os autores, é de suma importância não limitar a participação da comunidade a um único centro ou a uma trajetória linear de aquisição de habilidades. "Não há um lugar na Comunidade de Prática designado "a periferia" e não há um único núcleo ou centro" (LAVE e WENGER, 1991, p.36).

\footnotetext{
${ }^{4}$ Os textos de Etienne Wenger e Jean Lave são todos em inglês, portanto, as citações diretas aqui são traduções.
} 
Assim, de acordo com Bizerra:

"A participação periférica legitimada é um termo usado para caracterizar o modo como um novato integra-se a uma Comunidade de Prática. Sua inserção inicialmente periférica transforma-se gradualmente, em um processo de aprendizagem coletiva, possibilitando sua legitimação como membro potencial. Evidências de aprendizagem nesse modelo de participação em comunidades envolveriam, portanto, transformações na participação dos sujeitos em atividades socioculturais ao assumirem mais responsabilidades em determinada atividade." (BIZERRA, 2009, p.59).

Nesta perspectiva, Wenger (1998) introduz a ideia de Comunidades de Prática (COPs), afirmando que estão em toda parte, que todos participam de pelo menos uma (seja no trabalho, na escola ou em casa) e que elas mudam ao longo da vida. Mas quais seriam os elementos principais que configurariam uma COP? Qualquer agrupamento de pessoas poderia ser considerado uma COP?

Para um aprofundamento nesta questão, a seguir, serão apresentados os elementos principais dessa perspectiva, considerando-se que representam os fundamentos teóricos centrais dessa investigação.

\subsection{Comunidades de Prática}

Como definido anteriormente, uma COP é um agrupamento de pessoas que possuem uma preocupação ou uma paixão por algo que fazem e juntos aprendem como fazer isso melhor. Mais ainda, uma COP é formada por pessoas que se envolvem em um processo de aprendizagem coletivo que pode ser intencional ou não (WENGER, 2006).

As COPs são comuns, fazem parte do cotidiano de todas as pessoas. Wenger (1998) cita como exemplo os grupos familiares:

"Famílias lutam para estabelecer uma maneira habitável de vida. Eles desenvolvem suas próprias práticas, rotinas, rituais, artefatos, símbolos, convenções e histórias. Os membros da família se odeiam e se amam, eles concordam e discordam. Eles fazem o que é preciso para continuar. Mesmo quando as famílias se desfazem, os membros criam maneiras de lidar com o outro. Sobreviver em conjunto é um importante empreendimento, se sobreviver consiste na busca de comida e abrigo ou na busca de uma identidade viável." (WENGER, 1998, p.6).

De acordo com Wenger e Snyder (2000, p.142; apud, GOUVÊA, et al., 2008, p. 50), uma COP se diferencia de outras estruturas organizacionais, como grupos de trabalho formal, equipes e redes de trabalho informal, quanto ao objetivo, à constituição dos membros participantes, ao que os mantém unidos e à duração, como é mostrado na tabela 02 a seguir: 
Tabela 02. Comparação entre COP e outras estruturas organizacionais (GOUVÊA et al., 2008, p.50).

\begin{tabular}{|c|c|c|c|c|}
\hline & $\begin{array}{c}\text { Qual é o } \\
\text { objetivo? }\end{array}$ & $\begin{array}{c}\text { Quem } \\
\text { participa? }\end{array}$ & $\begin{array}{l}\text { O que têm em } \\
\text { comum? }\end{array}$ & $\begin{array}{c}\text { Quanto tempo } \\
\text { dura? }\end{array}$ \\
\hline $\begin{array}{l}\text { Comunidade } \\
\text { de Prática }\end{array}$ & $\begin{array}{l}\text { Desenvolver as } \\
\text { competências dos } \\
\text { participantes; } \\
\text { gerar e } \\
\text { compartilhar } \\
\text { conhecimentos. }\end{array}$ & $\begin{array}{l}\text { Participantes } \\
\text { se auto } \\
\text { selecionam. }\end{array}$ & $\begin{array}{c}\text { Paixão, } \\
\text { compromisso e } \\
\text { identificação com } \\
\text { os conhecimentos } \\
\text { especializados do } \\
\text { grupo. }\end{array}$ & $\begin{array}{c}\text { Enquanto houver } \\
\text { interesse em } \\
\text { manter o grupo. }\end{array}$ \\
\hline $\begin{array}{l}\text { Grupo de } \\
\text { trabalho } \\
\text { formal }\end{array}$ & $\begin{array}{l}\text { Desenvolver um } \\
\text { produto ou prestar } \\
\text { um serviço. }\end{array}$ & $\begin{array}{l}\text { Qualquer um } \\
\text { que se } \\
\text { apresente ao } \\
\text { gerente do } \\
\text { grupo. } \\
\end{array}$ & $\begin{array}{l}\text { Requisitos do } \\
\text { trabalho e metas } \\
\text { comuns. }\end{array}$ & $\begin{array}{l}\text { Até a próxima } \\
\text { reorganização. }\end{array}$ \\
\hline Equipe & $\begin{array}{c}\text { Realizar } \\
\text { determinada } \\
\text { tarefa. }\end{array}$ & $\begin{array}{c}\text { Os } \\
\text { participantes } \\
\text { são escolhidos } \\
\text { pelos gerentes. }\end{array}$ & $\begin{array}{l}\text { As metas e pontos } \\
\text { importantes do } \\
\text { projeto. }\end{array}$ & $\begin{array}{c}\text { Até o final do } \\
\text { projeto. }\end{array}$ \\
\hline Rede Informal & $\begin{array}{c}\text { Coletar e } \\
\text { transmitir } \\
\text { informações } \\
\text { empresariais. }\end{array}$ & $\begin{array}{l}\text { Amigos e } \\
\text { conhecidos do } \\
\text { ambiente de } \\
\text { trabalho. }\end{array}$ & $\begin{array}{l}\text { Necessidades } \\
\text { mútuas. }\end{array}$ & $\begin{array}{c}\text { Enquanto houver } \\
\text { um motivo para } \\
\text { manterem } \\
\text { contato. }\end{array}$ \\
\hline
\end{tabular}

Wenger (Team BE, 2011) ainda argumenta que as COPs possuem como elementos chaves o domínio, a comunidade e a prática. O domínio refere-se à necessidade compartilhada, explícita ou não, de aprender algo. Essa necessidade define a identidade da COP e pode ser motivo para unir os membros participantes ou pode ser produto da união deles. O compromisso com o domínio caracteriza o membro participante de uma COP. A comunidade refere-se ao vínculo criado através do engajamento dos membros em torno de um domínio comum, gerando ambiente propício para troca de experiências. Os membros se envolvem em atividades conjuntas e discussões, ajudam uns aos outros e compartilham informações. Eles constroem relações que lhes permitem aprender uns com os outros. "Os impressionistas, por exemplo, costumavam se encontrar em cafeterias e estúdios para discutir o estilo de pintura que eles estavam inventando juntos. Essas interações foram essenciais para torná-los uma Comunidade de Prática, mesmo que, muitas vezes, eles pintassem sozinhos" (WENGER, 2006). E por fim, a prática refere-se ao desenvolvimento de um repertório compartilhado de recursos (documentos, experiências, histórias, vocabulário comum, ferramentas, métodos, entre outros) (GOUVÊA et al., 2008) que reifiquem ${ }^{5}$ a interação dos membros com o domínio em comum.

\footnotetext{
5 O termo reificado é usado por Wenger (1998) para se referir à concretização de ideias, por exemplo, a construção de artefatos, conceitos, métodos, entre outros, são formas de reificar ideias.
} 
A prática defendida por Wenger (1998) não é só o fazer em si, mas engloba também o contexto histórico e social que dá estrutura e sentido ao que é feito. "Nesse sentido, a prática é sempre uma prática social” (WENGER, 1998, p.47). A prática defendida por Wenger (1998) inclui o explícito, como imagens, ferramentas, documentos, linguagem, símbolos, regras bem definidas, mas também inclui o tácito, as relações implícitas, percepções específicas, sensibilidades bem sintonizadas. Ela também não é um antônimo para teoria, pois as COPs incluem os dois elementos, teoria e prática. As comunidades são locais ${ }^{6}$ onde se pode refletir sobre as teorias e visão de mundo dos participantes. Além disso, a prática não está imune à influência da teoria, é inclusive importante que a comunidade pratique a reflexão de suas ações (Ibid.).

Para relacionar a prática ao termo comunidade, ele analisa três dimensões básicas: engajamento mútuo, empreendimento conjunto e repertório compartilhado. Essas dimensões, representadas na Figura 02, podem ser utilizadas para distinguir uma COP de outras comunidades quaisquer, evitando-se assim uma banalização do uso do termo.

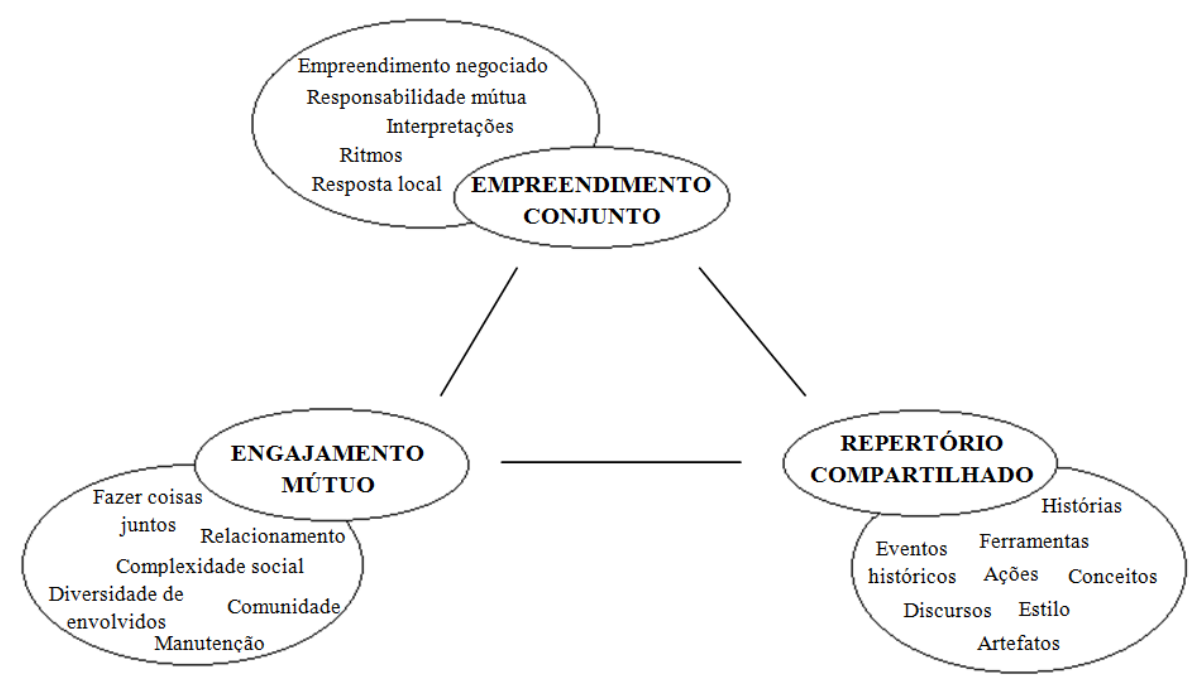

Figura 02. Dimensões da prática como propriedade de uma comunidade (WENGER, 1998, p. 73).

\subsubsection{Engajamento Mútuo}

De acordo com Wenger (1998), o engajamento mútuo é a primeira característica para definir uma COP e observando a Figura 02, pode-se notar que este elemento engloba fazer

\footnotetext{
${ }^{6}$ Entendem-se locais aqui não como algo físico, mas um espaço, indeterminado fisicamente, utilizado para discussões.
} 
coisas juntos, diversidade de envolvidos, relacionamento, complexidade social, comunidade e manutenção.

Para explicar esses itens, Wenger (1998) defende que o engajamento de pessoas em ações gera a prática, cujos significados são negociados entre os participantes. Isto é, em uma comunidade, a prática existe por causa das relações de engajamento mútuo - compromisso existente entre os membros da comunidade para que esses realizem um empreendimento conjunto, ou seja, para que façam algo juntos.

O engajamento mútuo é caracterizado pela filiação dos membros à comunidade e pelas relações de compromisso mútuo entre eles e com o que eles fazem. $\mathrm{O}$ autor ainda argumenta que uma COP não pode ser confundida com um agregado de pessoas, e nem ser sinônimo de grupo, ou time. Ressalta que filiação não é somente uma questão de categoria social e que a proximidade geográfica não é o que definirá a prática. Cita como exemplo, a relação entre funcionários de uma empresa, evidenciando que não basta estarem no mesmo escritório para que sejam considerados pertencentes a uma COP. Para serem considerados uma COP, os envolvidos precisam ter um engajamento mútuo organizado em torno de uma prática. Estar engajado na comunidade significa ser incluído em algo que é realmente necessário. E, indo além, um participante pleno sabe distinguir entre o que é necessário e o que não é (Ibid).

Apesar de o termo engajamento mútuo soar como sinônimo de homogeneização, Wenger atenta para a heterogeneidade das COPs. Cada pessoa tem sua identidade, o que torna uma COP heterogênea. O trabalho em conjunto gera tanto diversidades quanto similaridades. Para exemplificar, o autor cita os diferentes tipos de pessoas que podem ser contratadas em uma empresa: pessoas idosas, novas, conservadoras, liberais, introvertidas, extrovertidas. Como ressalta, "são diferentes um do outro e tem aspirações e problemas pessoais diferentes" (WENGER, 1998, p.75). Para Wenger, cada participante da COP adquire um lugar único, isto é, ganha uma identidade singular dentro da comunidade. E é essa identidade que irá definir o curso do engajamento na prática. Isso explica os diferentes níveis de engajamento em uma comunidade. Explica, por exemplo, a diferença hierárquica entre um supervisor e um assistente de supervisor. Ambos tiveram uma ascensão na carreira e continuam engajados na prática, contudo, eles adquiriram status diferentes tanto em relação à autoridade, quanto ao próprio trabalho diário e à relação com a corporação, devido à diferença de identidades, podendo um ter se especializado mais do que o outro. Contudo, essas pessoas estão ligadas pelo engajamento mútuo a uma prática. Ao mesmo tempo em que se especializam e se distinguem um do outro, desenvolvem maneiras comuns de fazer as coisas. 
Para completar, Wenger também defende que o engajamento mútuo não é constituído somente pela competência de uma pessoa, mas inclui as competências dos demais membros da comunidade. O engajamento mútuo pode envolver tanto contribuições complementares como sobreposição de competências. É nesse parâmetro que a comunidade deve saber negociar seus significados em favor de uma prática em comum. "Em uma Comunidade de Prática, onde as pessoas se ajudam mutuamente, é mais importante saber como dar e receber ajuda do que tentar saber tudo sozinho" (WENGER, 1998, p.76).

O engajamento mútuo definirá as relações estabelecidas entre os membros de uma COP, fazendo com que esses saibam identificar as próprias competências e as dos outros. Além disso, criará um espaço produtivo para o compartilhamento de conhecimentos. Isso é o que acontece, por exemplo, na relação entre membros veteranos e membros novatos de uma COP.

Sendo assim, a COP é sustentada por uma densa relação de engajamento mútuo organizado em torno de uma prática e, de acordo com essas competências, e consequentemente, com a identidade de cada membro é possível que o engajamento aconteça em vários níveis de participação, do centro à periferia (WENGER, 1998). Esses níveis podem ser utilizados para detectar o engajamento mútuo.

É importante mencionar aqui, que a participação não é um sinônimo de engajamento. Wenger (1998) argumenta que a participação pode envolver todos os tipos de relações, desde as conflitais até as harmônicas, da competitiva até a cooperativa e ela molda a experiência que o membro tem em sua prática. A participação é mais abrangente do que o engajamento, pois ela não acaba quando o membro vai para casa. Ele não está engajado na prática naquele momento, mas continua participando da Comunidade de Prática. “A participação não é algo que podemos ligar ou desligar" (WENGER, 1998, p. 57).

Nota-se que mesmo frente à diversidade de identidades presentes em uma COP, ela tem sua existência garantida graças ao engajamento mútuo. O nível de engajamento, por sua vez, é definido pelas identidades dos membros da comunidade, pela ideia de pertencimento ao grupo, pelos níveis de participação e pelas interações entre os membros. Estudos que pretendem analisar o engajamento mútuo em COPs deveriam, portanto, atentar para essas características. 


\subsubsection{Empreendimento Conjunto}

O empreendimento conjunto é o segundo aspecto utilizado por Wenger para identificar uma COP. De acordo com a Figura 02 (apresentada nesse trabalho, p.30), este elemento compreende o empreendimento negociado, responsabilidade mútua, interpretações, ritmos e resposta local. Wenger (1998) complementa essa figura, apontando três características desse termo:

"1. É o resultado do processo coletivo de negociação que reflete toda complexidade do engajamento mútuo.

2. É definido pelos participantes no próprio processo de construí-lo. É a resposta negociada para a situação e, portanto, pertence a eles em um sentido profundo, apesar de todas as forças e influências que estão além do controle deles.

3. Não é apenas um objetivo declarado, mas cria entre os participantes relações de responsabilidade mútua que se tornam parte integrante da prática” (WENGER, 1998, p.77).

O empreendimento reflete a complexidade da prática e inclui aspectos instrumentais, pessoais e interpessoais da vida de cada membro. Wenger (1998) cita, como exemplo, a prática dos processadores de sinistro de seguradoras "que envolve, entre outras coisas, ganhar dinheiro, ser um adulto, tornando-se proficiente em processamento de sinistros, se divertindo, fazendo bem, se sentindo bem, não sendo ingênuo, sendo apresentável, lidando com o tédio, pensando no futuro, mantendo o seu lugar" (WENGER, 1998, p.78).

Isto significa que o empreendimento conjunto de uma COP é definido pelo engajamento mútuo na prática. Como o engajamento mútuo não requer a homogeneidade, o empreendimento conjunto não reflete necessariamente que todos os membros concordem entre si. O autor destaca, inclusive, que em algumas COPs, a discrepância de pontos de vista pode ser produtiva para a comunidade. $\mathrm{O}$ empreendimento conjunto não é sinônimo de que os membros acreditem/pensem na mesma coisa, mas é fruto da negociação definida pelos participantes durante a sua constituição.

Dizer que os membros de uma COP compartilham um empreendimento não é simplesmente dizer que eles compartilham condições de trabalho, que eles têm dilemas em comum, ou que criam respostas similares. Mas entender que as respostas para essas condições e dilemas são interconectadas porque os membros estão engajados mutuamente no que fazem 
em conjunto - o empreendimento. Wenger (1998) completa que faz parte desse processo que os membros encontrem um caminho para realizar o empreendimento em conjunto, vivendo com as diferenças e coordenando suas próprias aspirações.

Wenger (1998) atenta para o fato de que as COPs não são entidades independentes e estão inseridas em contextos maiores, sejam eles, históricos, sociais, culturais e/ou institucionais, com recursos específicos e restrições. Contudo, mesmo que esses contextos modelem as condições de trabalho da comunidade, são os membros que produzem a sua realidade, de acordo com o seu cotidiano. Somente o que é negociado pela comunidade, molda a prática. Isso não quer dizer que a comunidade não pode ser influenciada ou ajudada por agentes externos, mas quer dizer que o poder que esses agentes têm sobre a prática de uma comunidade é sempre mediado pela própria comunidade, pois só ela pode negociar sua prática.

"A negociação de um empreendimento conjunto dá origem a relações de responsabilidade mútua entre os envolvidos” (WENGER, 1998, p.81). A definição dessa responsabilidade é um processo, e não um acordo estático. Ela envolve tanto o que é importante, quanto o que não é para a comunidade, envolve o desenvolvimento de sensibilidades especializadas e percepções refinadas para fazer julgamentos sobre a prática desenvolvida, permitindo aos participantes negociar a adequação do que eles fazem. Ela define em quais circunstâncias os membros de uma COP devem se preocupar ou não com o que estão fazendo, com o que acontece com eles e ao redor deles. Envolve, também, tornar o dia a dia do trabalho mais suportável, mais fácil.

A articulação da responsabilidade à prática não é algo fácil, porque, mesmo que algo seja reificado, ele será negociado na prática até tomar uma forma agradável aos membros da comunidade. De acordo com Wenger (1998), a responsabilidade mútua torna-se parte integrante da prática. A prática inclui o modo como os participantes interpretam os aspectos reificados de responsabilidade e os integram nas formas vividas de participação. Ser capaz de fazer distinções entre as normas reificadas e engajamento competente na prática é um aspecto importante para se tornar um membro experiente. Mesmo quando o empreendimento é reificado, a prática evolui para uma interpretação negociada.

O empreendimento conjunto faz parte da prática da mesma forma que o ritmo é parte da música (WENGER, 1998). Ele dá as coordenadas, dá sentido ao que os membros de uma COP fazem juntos. Sendo assim, um empreendimento passa a ser fonte de engajamento mútuo e dá sentido à prática da comunidade. 


\subsubsection{Repertório Compartilhado}

A terceira característica para identificação de uma COP é o desenvolvimento de um repertório compartilhado. O repertório de uma comunidade pode ser bem heterogêneo e inclui "rotinas, palavras, ferramentas, maneira de fazer as coisas, histórias, gestos, símbolos, gêneros, ações, ou conceitos que a comunidade tenha produzido ou adotado no curso de sua existência, e que se tornaram parte de sua prática" (WENGER, 1998, p.83).

Neste sentido, o repertório compartilhado, segundo Wenger (1998), reflete o histórico do engajamento mútuo. Esse histórico cria pontos compartilhados de referência, mas é importante evidenciar que isso não significa que há uma imposição de significados. Wenger coloca que "coisas como palavras, artefatos, gestos e rotinas são úteis não só porque eles são reconhecíveis em sua relação com um histórico de engajamento mútuo, mas também porque pode ser ligado novamente em situações novas" (WENGER, 1998, p.83). Contudo, não há um impedimento de que novos significados sejam criados de acordo com a necessidade da comunidade.

O estabelecimento do repertório de uma comunidade, então, pode ser visto como fonte de negociação de significados. Um participante experiente consegue diferenciar pontos que já são parte do histórico do engajamento mútuo da comunidade e pontos que necessitam ter o significado renegociado.

Sendo assim, os três aspectos elucidados - engajamento mútuo, empreendimento conjunto e repertório compartilhado - são utilizados para se caracterizar comunidades de práticas de diferentes campos de atuação humana. Mas como as COPs podem ser entendidas no campo da Educação Não Formal, foco do presente trabalho?

\subsection{As Comunidades de Prática em Espaços de Educação Não Formal}

A teoria sobre comunidades de prática tem sido muito empregada na área da formação de professores, como apresentado nos trabalhos de Baldini e Cyrino (2012); Beline (2012); Cyrino e Caldeira (2011); Moser (2010); Miskulin et al. (2009). Contudo, são poucos os trabalhos que relacionam comunidades de prática e espaços de Educação Não Formal.

O trabalho de Mônaco (2013) é um desses. Em sua pesquisa de doutorado, Mônaco defende que museus podem ser considerados comunidades de prática, não do ponto de vista do indivíduo, mas da instituição. Para a autora, as práticas desenvolvidas nos museus são 
partilhadas com outras comunidades que deles fazem parte, como a de mediadores, cientistas, educadores e a do núcleo educativo.

Nesta perspectiva, a autora tem por objetivo entender como elementos da identidade dessas comunidades podem explicar a visão delas sobre biodiversidade. Além disso, a autora pretendeu investigar se a participação de indivíduos nessas comunidades é o suficiente para que estes definam os seus significados sobre o termo biodiversidade ou se a identidade deles influencia de alguma forma a escolha.

Outro trabalho que aborda a teoria das COPs em museus é o da Bailey (2003). Bailey trabalha mais especificamente com os mediadores de museus e a construção do conhecimento para a prática de educação nesses locais. Ela fez entrevistas com 15 mediadores de museus de ciência de Massachusetts. Por meio da análise dessas entrevistas, Bailey (2003) argumenta que os mediadores de instituições museais compõem uma Comunidade de Prática. Sua pesquisa conclui que a construção de conhecimento desses profissionais acontece por meio de auto direcionamento na aprendizagem; motivação para participar e aprender; oportunidade de aprendizagem em pares; comunidade e cultura que valorizam e apoiam os aspectos social, contextual e colegial do aprendizado; estrutura organizacional e de liderança para apoiar o crescimento profissional; uma rede inter-relacionada de comunidades de prática que fornece apoio e acesso aos recursos.

Apesar dos dois estudos apresentarem o uso das COPs em museus de ciências, nenhum dos dois trabalhos enfatiza o processo de formação dos mediadores desses espaços. Neste sentido, este estudo pretende colaborar com esta área de pesquisa, adicionando o uso de COPs no processo formativo dos mediadores de espaços de Educação Não Formal.

Inicialmente, o Engajamento Mútuo, o Empreendimento Conjunto e o Repertório Compartilhado serão utilizados, neste trabalho, para tentar identificar se grupos de mediadores de espaços não formais de educação podem ser considerados como comunidades de prática, tendo como estudo de caso a Estação Biologia (EB) do Instituto de Biociências da Universidade de São Paulo. Em seguida, caso a EB seja considerada uma COP, será investigado o Engajamento Mútuo como elemento formativo de seus mediadores. Para isso, serão mostrados, no próximo capítulo, os percursos metodológicos escolhidos para se chegar a essas respostas. 


\section{Capítulo 3. Percursos metodológicos}

Neste capítulo, será apresentado o local de estudo escolhido, quanto ao seu histórico, à sua dinâmica de funcionamento e às características que este tem para ser considerado um espaço de Educação Não Formal. Além disso, será mostrado o método de coleta e de análise de dados utilizado.

\subsection{Contextualização do espaço estudado:}

O local de estudo escolhido foi a Estação Biologia - EB. Trata-se de um projeto de extensão universitária vinculada à Comissão de Cultura e Extensão (CCEx) do Instituto de Biociências da Universidade de São Paulo e coordenada pelas professoras Beatriz Pacheco Jordão e Alessandra Bizerra.

Nesta seção, serão apresentados o histórico e a dinâmica de funcionamento da EB, além da caracterização desta, como espaço de Educação Não Formal. As informações sobre a EB contidas aqui foram retiradas de documentos internos produzidos pelos próprios mediadores.

\subsubsection{Histórico da EB}

A EB, antiga Comissão de Visitas (CV), surgiu em 1986 com a função de receber grupos escolares de $1^{\circ}$ e $2^{\circ}$ graus das redes estadual e municipal de ensino, a pedido da extinta Coordenadoria de Divulgação de Atividades Culturais (CODAC). Contudo, nos dois primeiros anos não houve recepção de visitas, sendo essas iniciadas somente em 1988. Os registros de visitas e visitantes tiveram início em 1989. Em 1992, a CV torna-se vinculada à recém-criada Comissão de Cultura e Extensão (CCEx) e um professor coordenador passa a ser responsável pela gestão direta do projeto.

Primeiramente, o público visitante era recepcionado em auditórios e as principais atividades eram constituídas de apresentações de slides, vídeos e passeios pelo Instituto de Biociências. Os slides e vídeos abordavam temáticas de biologia, como zoologia e botânica e os passeios consistiam em visitar o jardim do IB, a exposição de zoologia e o apiário. Nessa época, a CV era composta por alguns docentes e dois mediadores remunerados. 
Depois, a CV passou a contar com um coordenador, seis mediadores bolsistas e mediadores voluntários. Suas atividades foram reformuladas, tendo como foco a educação ambiental e começaram a ser separadas de acordo com a formação escolar do visitante.

"Para as primeiras séries, aplicava-se o Jogo das Pegadas, Apiário e Passeio ao Jardim. Para as $7^{a}$ e $8^{a}$ séries aplicava-se Geoesterograma, o audiovisual $O$ Dia da Terra, Jogo do Lixo, Jardim e Roda do Equilíbrio. Para o colegial eram aplicadas as atividades Estudo do Meio e Fisiologia”. (Manual de Sobrevivência da Estação Biologia, 2011 ${ }^{7}$ )

Mais tarde, houve uma modificação nessas atividades para que elas não ficassem restritas à educação ambiental, abrangendo outros aspectos, como conceitos históricos e avanços tecnológicos.

Em 2002, uma sala do edifício Félix Kurt Rawitscher, conhecido como Minas, foi reformada e readequada para que a $\mathrm{CV}$ pudesse ter um ambiente próprio, dando suporte para uma maior atuação e autonomia dos mediadores no desenvolvimento de atividades com o público visitante.

Em 2010, por iniciativa dos mediadores em conjunto com a professora coordenadora, Beatriz Pacheco Jordão, o nome oficial da CV foi modificado para Estação Biologia, como parte de um conjunto de medidas para divulgação do projeto. A mudança do nome, porém, não alterou a dinâmica de funcionamento do grupo.

Atualmente, a EB continua recebendo alunos do ensino fundamental e médio, contudo, também, recebe visita de grupos de idosos, detentos e educação infantil. A visitação acontece somente mediante a marcação prévia. Além da visitação, o grupo participa de eventos como a Feira das Profissões, realizada pela USP, a Semana Nacional da Ciência e da Tecnologia, Bio na Rua, organizado pelo CA do curso de Ciências Biológicas e o Dia de Darwin, promovido pelo museu de Zoologia. Os temas abordados nas visitas são referentes à Biologia, como biodiversidade, fisiologia dos sentidos, genética, entre outros.

\footnotetext{
${ }^{7}$ Documento de uso interno, escrito pelos próprios mediadores da EB, contendo um resumo do histórico, a estrutura atual, definição das atividades realizadas interna e externamente pelos mediadores, procedimentos, apresentação de documentos necessários, como a ficha avaliativa pósvisita, termos de autorização, entre outros, estabelecimento de regras e posturas. Esse documento é utilizado como referência durante os encontros formativos dos mediadores novatos. Versão 2011. Documento não publicado.
} 


\subsubsection{Dinâmica de funcionamento da EB}

No início de cada ano letivo, os alunos veteranos do curso de Ciências Biológicas da USP fazem uma semana de boas findas aos calouros. Isso inclui apresentar todos os grupos com atividades extracurriculares, como o Centro Acadêmico, a Atlética, o grupo que organiza a Semana Temática de Biologia, a Estação Biologia, entre outros. Os alunos interessados nas atividades da EB passam por uma semana de treinamento, ministrado pelos mediadores veteranos, e se decidirem continuar, começam a atuar nas visitas.

Os mediadores são divididos em comissões, as quais são responsáveis pelo desenvolvimento das atividades de visitação em dias fixos da semana, como em um trabalho por escala. Isso acontece devido à grande quantidade de mediadores existentes na EB e para que haja uma maior disponibilidade/flexibilidade para marcação de visitas.

Podem ser bolsistas ou voluntários. Os bolsistas são mantidos pela CCEx do Instituto de Biociências e disponibilizam 12 horas semanais para as atividades da EB, enquanto os voluntários disponibilizam 6 horas. Essas horas são divididas entre visitas e manutenções.

Os mediadores da EB, além de atuar durante as visitas, têm várias funções, como, marcar e preparar as visitas, organizar, consertar e criar materiais para as atividades, criar atividades novas, fazer a manutenção dos animais vivos, manter a sala organizada e limpa, entrar em contato com a portaria do edifício Minas para avisar quando haverá visitas, entrar em contato com os setores responsáveis para repor materiais, participar de reuniões para ajustes internos, entre outras.

As visitas podem ocorrer em dois espaços, na sala da EB (Figura 03) - auditório 4, do prédio Félix Kurt Rawitscher (prédio Minas) - ou no Sobre as Ondas (Figura 03), jardim do departamento de botânica. 


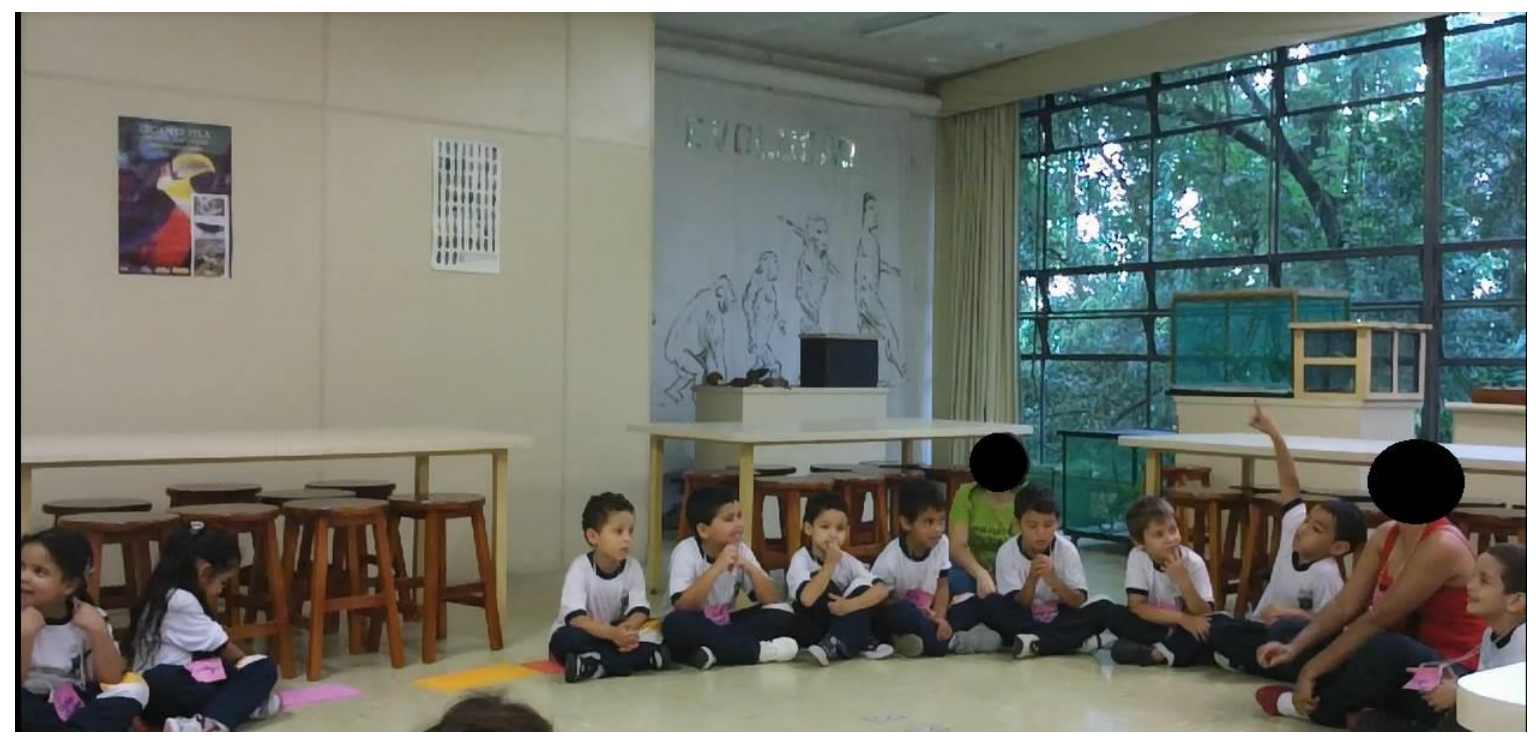

Figura 03. Sala da EB, auditório 4, do prédio Félix Kurt Rawitscher (prédio Minas).

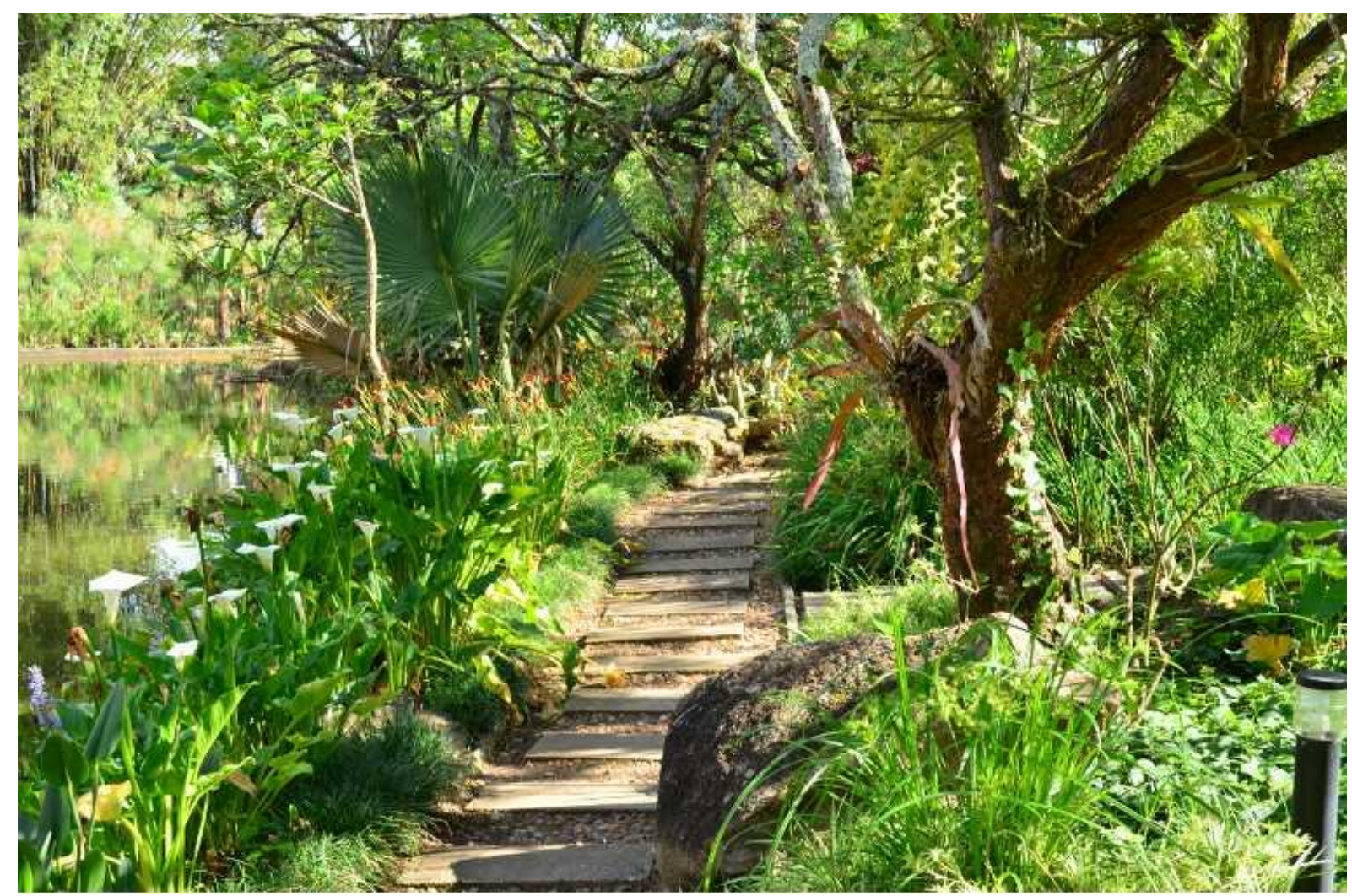

Figura 04. Jardim do departamento de botânica - Sobre as Ondas.

As visitas são agendadas por telefone ${ }^{8}$, por e-mail ${ }^{9}$ ou pelo próprio site $^{10}$, no qual estão disponíveis o calendário de disponibilidade do grupo e as descrições das atividades desenvolvidas. As atividades que podem ser escolhidas no momento da marcação são:

\footnotetext{
${ }^{8}$ Os agendamentos por telefone só podem ser feitos de segunda a sexta-feira, das 12 às 14 horas - horário de funcionamento da secretaria da EB.

9 estacaobiologia@ib.usp.br
} 
1. Educação Sexual: atividade recomendada para alunos acima do $8^{\circ}$ ano do Ensino Fundamental. Consiste em uma conversa sobre o tema, uma palestra sobre DST, estações $^{11}$ de discussão sobre métodos anticoncepcionais, anatomia dos sistemas reprodutores, período menstrual, gravidez e urna de dúvidas, na qual os alunos depositam perguntas que são lidas e respondidas pelos mediadores. Dura em média três horas.

2. Jogo dos Micos: atividade com duração de 30 minutos e recomendada para alunos de Educação Infantil à Ensino Fundamental. Nessa atividade, é simulado um desmatamento para sensibilizar as crianças sobre a importância da preservação ambiental.

3. Sentindo a Vida: essa atividade, que se destina a crianças de 5 a 10 anos, consiste em três jogos dos sentidos - tato: um objeto biológico é desenhado sem ser visto; audição: uma história é depreendida de sons, olfato: no jardim as crianças são levadas a sentir novos aromas. Tem duração de uma hora e quinze minutos.

4. Filho de Scoiso, Scoisinho é! (Laboratório da Genética): essa atividade foi desenvolvida por professores do departamento de Genética e Biologia Evolutiva e é recomendada para alunos do Ensino Médio. Tem duração de, aproximadamente, uma hora e quinze minutos e os alunos aprendem noções básicas de genética, formação de gametas através de meiose e de zigoto através da fecundação. Nessa atividade, os alunos montam um organismo (Scoiso) imaginário de acordo com as características herdadas e contam uma história de como os pais Scoisos se conheceram.

5. DNA da Banana: atividade de duração de aproximadamente 30 minutos, cujo público alvo são os alunos do Ensino Médio. Nessa atividade, os mediadores, com auxílio de um aluno, realizam a extração do DNA da banana, promovendo uma discussão sobre a localização do DNA na célula, sua função e o porquê de cada etapa feita nos procedimentos para extrair o DNA da banana.

6. Fisiologia: essa atividade é feita com alunos desde o Ensino Fundamental II ao Ensino Médio e, como a atividade Sentindo a Vida, trabalha com os sentidos, porém de forma diferenciada. Tem duração média de uma hora e quinze minutos e são feitos

\footnotetext{
${ }^{10}$ www.ib.usp.br/estacaobiologia

${ }^{11}$ Os mediadores da EB dividem os visitantes em grupos para determinadas partes do desenvolvimento da atividade. Em média, cada grupo é acompanhado por pelo menos dois mediadores que os auxiliam na tarefa a ser desenvolvida, ou explicam sobre o assunto que está sendo visto. Os mediadores referem-se a esses grupos com atendimento particular como estações.
} 
experimentos com os alunos para abordar a função dos cones e bastonetes (visão), a importância das terminações nervosas (tato) e a interdependência entre olfato e paladar. 7. Inter-Ações: essa atividade, cuja duração média é de uma hora e quinze minutos, é feita com alunos de Ensino Fundamental I e II. Ela aborda as interações entre os seres vivos e, para isso, é constituída de três etapas. A primeira é feita na sala da EB, onde se explica sobre interações ecológicas para os visitantes. Na segunda etapa, os alunos são levados ao jardim Sobre as Ondas e devem procurar exemplos de interações ecológicas. $\mathrm{Na}$ última etapa, de volta à sala, os alunos contam o que acharam no jardim e define-se a equipe vencedora (o grupo que achou mais exemplos de interações).

8. Teatro dos Abelhudos: essa atividade é feita com crianças de cinco e seis anos. Tem duração de uma hora e quinze minutos e consiste em explicar de forma divertida conceitos básicos sobre insetos sociais, como as abelhas.

9. Trilha da Biodiversidade: é recomendada a alunos de Ensino Fundamental e Médio. Nessa atividade, é apresentada uma noção geral sobre biodiversidade e seleção natural, utilizando-se diversos recursos, como esqueletos, animais vivos, animais taxidermizados, plantas do jardim Sobre as Ondas, entre outros. É uma das atividades mais solicitadas da EB. Dura em média uma hora e quinze minutos.

Após a marcação da visita, os mediadores se preparam para tal, estudando o protocolo de atividades ${ }^{12}$, verificando o material necessário para a atividade escolhida e se plotando para o desenvolvimento da mesma. Essa plotagem é feita de maneira virtual e consiste na escolha de como cada mediador irá atuar no dia da visita. Já o protocolo de atividades é utilizado como referência para preparação das visitas. Nele encontram-se descritos o objetivo de cada atividade, assim como, o público-alvo, os materiais utilizados, como preparar a visita, conceitos envolvidos, como é o desenvolvimento da atividade e bibliografias que podem ser consultadas. Esse protocolo é muito utilizado, principalmente, pelos mediadores novatos que ainda se sentem inseguros na hora de apresentar a atividade em uma visita. Apesar de ser um documento completo, os mediadores tem total autonomia para acrescentar ou omitir informações conforme preferência.

Ao final de cada visita, são aplicados questionários de avaliação a serem respondidos pelos alunos e professores. Esses questionários são utilizados para gerar relatórios enviados para a CCEx e são importantes para analisar o trabalho dos mediadores e a viabilidade de cada atividade ministrada. Além deste questionário, ao final de cada visita, os mediadores

\footnotetext{
${ }^{12}$ Também presente no Manual de Sobrevivência da Estação Biologia.
} 
participantes conversam sobre a visita, anotando tudo em um livro - Livro de Visitas. Neste livro, eles anotam:

"[...] o dia da visita (do mês e da semana), os dados da escola (Nome da Escola, pública ou particular, número de alunos, nomes dos acompanhantes - professores, estagiários, etc. -, série dos alunos), as atividades realizadas, os acontecimentos da visita, comentários dos monitores sobre a visita e o nome dos monitores presentes na visita". (Manual de Sobrevivência da Estação Biologia, 2011).

As manutenções são realizadas pelos mediadores fora dos horários de visita. Elas são feitas em relação ao espaço, aos materiais vivos presentes na sala e no jardim e aos demais materiais utilizados durante as visitas.

Em relação à manutenção do espaço, eles precisam manter o espaço limpo e organizado. Para manutenção dos seres vivos, existem protocolos contendo precauções que o mediador deve ter ao lidar com determinados animais, como proceder com a alimentação e a limpeza do local onde é mantido o animal. Na EB, existem Bichos-pau, aquários com peixes diversos, aranhas, baratas, tenébrios, escorpiões todos mantidos na sala da EB e plantas carnívoras e suculentas no jardim. A manutenção dos demais materiais consiste em conferilos e consertá-los se houver necessidade.

Para organização de todas essas atividades, a EB utiliza um canal de comunicação, um web site de uso interno - Gestão CV/EB, onde são feitas as plotagens para a realização das visitas e das manutenções e onde estão disponíveis versões online de protocolos de visitas e manutenção, de telefones úteis, da lista de pendências que devem ser realizadas e outras informações que podem ser acessadas por qualquer mediador.

\subsubsection{Caracterização da EB como espaço de Educação Não Formal}

A EB é um projeto de extensão universitária, contudo apresenta caráter de Educação Não Formal. Observando a Tabela 01 (apresentada na p.18 deste trabalho) mostrada na primeira seção, e tentando estabelecer uma correlação com a EB, tem-se que esse espaço realiza atividades com propósitos específicos, durante um curto prazo; o público visitante não passa por processo avaliativo ou recebe certificação após o término das mesmas; o controle é interno e democrático; a intencionalidade é centrada no aprendiz; a organização do conhecimento é acadêmica por estar vinculada a uma instituição de ensino superior; as atividades são semiestruturadas e pode-se dizer que possui um currículo, porém, determinado 
internamente. Sendo assim, as características apresentadas estão entre as categorias do continuum referido por Rogers (2004) e, por isso, pode-se definir a EB como um espaço de Educação Não Formal.

Todavia, a EB não pode ser considerada uma instituição museal por não possuir algumas características específicas dessas instituições. Sobre isso, Marandino (2005) traz elementos, apresentados por Van-Praet e Poucet (1989), presentes nas especificidades do museu, como o tempo, o lugar e o objeto. No museu, assim como na EB, o tempo gasto na visitação é curto quando comparado ao tempo gasto pelos alunos na instituição escolar. Contudo ao se falar do lugar e do objeto, a EB se distancia do conceito de museu. O lugar deve ser concebido como um trajeto aberto em detrimento ao espaço fechado da escola, onde o aluno não tem tanta escolha de caminhos a serem seguidos. Neste ponto de vista, o aluno também não possui essa flexibilidade na EB, isso porque as atividades a serem realizadas durante a visitação são pré-estabelecidas pela escola durante o agendamento, ou seja, o aluno possui um cronograma de atividades predeterminado, sem muita possibilidade de transitar livremente pela sala da EB. Mas o ponto fundamental que descaracteriza a EB como espaço museal está relacionado ao objeto. Os museus possuem acervos construídos historicamente, a partir de suas funções de recolher, conservar, estudar e expor objetos. Sabe-se que o discurso museal se apoia nesses artefatos, fonte de riqueza e interatividade. (ALLARD et al., 1996 apud MARANDINO, 2005).

Porém, quando se trata dos objetos da EB, nota-se que eles possuem uma característica mais próxima dos objetos utilizados em instituições de educação formal, onde o objeto tem o objetivo de instruir e educar o aluno, e é estruturado e utilizado em função da idade e da formação do público a ser atendido (Ibid.).

Assim, considera-se nesse trabalho que a EB possui características próprias as quais, ao mesmo tempo em que a coloca como um espaço de Educação Não Formal, também a distingue dos espaços não formais mais reconhecidos, como museus ou organizações não governamentais.

\subsection{Coleta de dados}

A investigação do processo de formação dos mediadores da Estação Biologia é um estudo de caso. De acordo com Yin (2001), esta é uma estratégia de pesquisa abrangente que “investiga um fenômeno contemporâneo dentro de seu contexto da vida real, especialmente 
quando os limites entre o fenômeno e o contexto não estão claramente definidos" (YIN, 2001, p. 32).

Para o autor, o estudo de caso deve ser utilizado quando o pesquisador não tem muito controle sobre as variáveis envolvidas, ou seja, quando se tratam de fenômenos sociais complexos. Isso condiz com o que está sendo abordado nessa pesquisa de mestrado que trata de um fenômeno social complexo: as relações e os elementos constituintes de uma Comunidade de Prática.

Além disso, o autor traz que o estudo de caso deve ser usado para responder perguntas do tipo "como" e "por que". Essas perguntas são mais explanatórias e lidam com processos, sendo necessário, assim, traçar procedimentos operacionais ao longo do tempo de estudo para que seja possível analisar o fenômeno em questão. No caso dessa pesquisa, a pergunta explanatória é "como o elemento engajamento mútuo pode contribuir para a formação inicial dos mediadores de espaços de Educação Não Formal?”. Essa questão está sendo analisada na Estação Biologia, lugar já definido anteriormente como espaço de Educação Não Formal, sendo os dados coletados ao longo de um ciclo completo ${ }^{13}$ de formação dos mediadores novatos.

Yin (2001) ainda argumenta que o “[...] o poder diferenciador do estudo é a sua capacidade de lidar com uma ampla variedade de evidências [...]” (YIN, 2001, p.27), sendo possível incluir diversas formas de coleta de dados. Nessa pesquisa, optou-se por análise de documentos, entrevistas e observações diretas como fontes de evidências, as quais serão descritas nos próximos itens.

\section{a) Análise documental}

A análise de documentos é indicada para buscar informações a partir de questões ou hipóteses de interesse e para quando se quer verificar ou validar informações obtidas por outras técnicas de coleta (YIN, 2001; LÜDKE E ANDRÉ,1986).

Os documentos são úteis para se verificar grafias corretas, cargos ou nomes de organizações, para fornecer detalhes específicos que vão ao encontro das informações obtidas a partir de outras fontes e para se encontrar novas questões sobre o caso estudado (YIN, 2001).

\footnotetext{
${ }^{13}$ Entende-se, aqui, o ciclo completo de formação como o período decorrido entre a entrada de mediadores novatos e o momento em que passam assumir a função de "veterano". No grupo analisado, esse período correspondeu a, aproximadamente, 18 meses.
} 
Em relação a essa técnica, foram coletados documentos internos da $\mathrm{EB}$, tais como histórico da instituição, materiais de divulgação, modelo de avaliação utilizado pós-visita, relatórios internos de visitas e de participação em eventos, materiais pedagógicos utilizados nas visitas e nos momentos de formação, guia da dinâmica de funcionamento do grupo produzido pelos próprios mediadores, atas de reunião, protocolos de conteúdos das atividades, entre outros.

\section{b) Entrevistas semiestruturadas}

De acordo com Yin (2001), "as entrevistas constituem uma fonte essencial de evidências para os estudos de caso, já que a maioria delas trata de questões humanas" (YIN, 2001, p.114).

Tendo isso em vista, foram realizadas duas etapas de entrevistas semiestruturadas gravadas (MINAYO, 2006), com perguntas abertas. Na primeira etapa, feita em maio de 2012, foram entrevistados onze mediadores, sendo cinco veteranos e seis novatos. Essa quantidade de mediadores foi escolhida de acordo com a dinâmica de funcionamento do projeto, já que existem muitos mediadores, sendo necessária a divisão em comissões ${ }^{14}$, as quais são responsáveis pelo desenvolvimento das atividades em dias fixos da semana. Além disso, a maioria dos integrantes atua de forma voluntária, tendo como consequência uma grande rotatividade. Sendo assim, a comissão de sexta-feira foi acompanhada e todos os mediadores que a compunham no primeiro semestre de 2012 foram entrevistados para garantir um mínimo de dados, caso uma parte dessa comissão se desfizesse. Apenas um mediador veterano não fazia parte dessa comissão. Ele foi entrevistado, porque os outros mediadores o identificaram como sendo o líder/centro administrativo da EB.

Dos seis mediadores novatos entrevistados na primeira etapa, somente três permaneceram na EB. Sendo assim, na segunda etapa, feita em setembro de 2013, aproximadamente três semestres depois das primeiras gravações, esses mediadores foram entrevistados novamente. Esse procedimento teve por objetivo analisar se as colocações feitas por esses mediadores teriam se modificado após algum tempo atuando na EB, dando indícios do processo formativo pelo qual passaram.

Além disso, os outros três mediadores que saíram da EB foram procurados para também serem entrevistados. Contudo, somente um demonstrou-se disponível para tal. Essa

\footnotetext{
${ }^{14}$ Essas comissões da EB são grupos de mediadores que atuam em determinados dias da semana, como em um trabalho por escala. Isso acontece devido à grande quantidade de mediadores existentes hoje na EB.
} 
entrevista teve por finalidade detectar os motivos de sua saída e sua percepção sobre seu engajamento na COP.

As entrevistas foram registradas com gravador de áudio Zoom HDQ3 e cada entrevista teve uma duração aproximada de 15 minutos.

c) Registro audiovisual e observações diretas de atividades

Os mediadores entrevistados foram filmados durante cinco visitas de aproximadamente três horas cada, totalizando cerca de 15 horas de gravação. Além disso, essas visitas, e outras atividades que não foram gravadas, foram observadas diretamente, obtendo-se anotações de campo (BOGDAN e BIKLEN, 1994).

O intuito dessas gravações e observações diretas foi analisar, na prática da mediação, as relações entre os membros da EB e a existência ou não dos elementos constituintes de uma Comunidade de Prática.

\subsection{Procedimentos analíticos}

A base de dados construída foi analisada separadamente para, em seguida, serem comparadas (BOGDAN e BIKLEN, 1994).

Para os documentos selecionados foi feita uma análise de conteúdo, definida por Berelson (1952, p.13, apud GIL, 2008) como "uma técnica de investigação que, através de uma descrição objetiva, sistemática e quantitativa do conteúdo manifesto das comunicações, tem por finalidade a interpretação destas mesmas comunicações" (BERELSON, 1952, apud GIL, 2008, p.152).

As entrevistas realizadas foram transcritas, utilizando-se o programa Transana. Os mediadores veteranos foram representados com a letra $V$ e os novatos pela letra $N$. As falas dos mediadores e do entrevistador foram divididas em turnos para facilitar a análise.

Depois de transcritas as entrevistas foram analisadas, utilizando-se como suporte o programa WebQDA, a partir de três categorias: engajamento mútuo, empreendimento conjunto e repertório compartilhado. Essas categorias foram criadas com a finalidade de identificar se a EB é uma Comunidade de Prática.

$\mathrm{Na}$ primeira categoria, foram consideradas falas envolvendo evidências do engajamento dos mediadores nas atividades da EB, tais como o nível de participação, a ideia de pertencimento, as interações entre os membros e a identidade dos mediadores. Na segunda 
categoria, foram levadas em consideração as falas que evidenciavam o empreendimento conjunto, como o objetivo em comum do grupo, a responsabilidade mútua e os significados negociados ou em negociação pelos membros da EB. Já a terceira categoria, contém falas sobre símbolos, rotinas, palavras, ações, artefatos, gestos, conceitos, normas, entre outros, utilizados pelos mediadores como repertório compartilhado.

As gravações e observações diretas foram analisadas, buscando-se indícios dos mesmos elementos: engajamento mútuo, repertório compartilhado e empreendimento conjunto. 


\section{Capítulo 4. Caracterização da Estação Biologia como uma Comunidade de Prática}

Neste capítulo, serão apresentadas as evidências encontradas nos dados coletados para argumentar que a EB pode ser considerada uma COP.

De acordo com Wenger (Team BE, 2011), uma COP possui como elementos chaves o domínio, a comunidade e a prática. O domínio é a necessidade compartilhada, explícita ou não, de aprender algo. Tendo como base os dados coletados na EB, pode-se notar que há necessidades compartilhadas pelos mediadores de aprender aspectos práticos de didática, como comunicar-se de maneira clara e fazer a transposição de conhecimento para o público visitante. Isso pode ser evidenciado em várias falas, como a do mediador $\mathrm{N} 1$ e do mediador N3:

Turno 19: [Entrevistador]: ...Por que você decidiu entrar na Estação Biologia?

Turno 20: [Mediador N1]: É, então. Primeiramente pra aprender a didática pra passar o conhecimento. Eu vejo pessoas que tem um conhecimento muito grande e não sabem repassar isso. E, também, pra eu entrar em alguma entidade da biologia, que não seja só as aulas ne. Eu queria fazer algum projeto fora das aulas. E, também, aprender a falar em público que é bem essencial e, às vezes, eu tenho um bloqueio pra isso. (Fala mediador N1 na primeira entrevista).

Turno 25: [Entrevistador]: E por que você escolheu entrar na Estação Biologia?

Turno 26: [Mediador N3]: Isso é porque eu tenho muita vergonha de falar em público. E eu achei que talvez fosse uma forma de eu começar a me soltar um pouco mais. Pra conseguir falar na frente das pessoas, explicar. (Fala mediador N3 na primeira entrevista).

Essa necessidade foi explicitada pelos mediadores, e esta vinculada à realidade dos graduandos do curso de Ciências Biológicas do IBUSP que enxergam a EB como uma oportunidade para se aproximar da prática da licenciatura. Apesar de muitos entrarem no curso com a intenção de permanecerem no bacharelado ${ }^{15}$, eles não descartam a ideia de exercer a docência e por isso, enxergam a EB como um local onde podem aprender "na

\footnotetext{
${ }^{15} \mathrm{O}$ curso de Ciências Biológicas do Instituto de Biociências da USP (IBUSP) é composto, inicialmente, por um núcleo básico que possui disciplinas comuns à Licenciatura e ao Bacharelado. Ao completar $85 \%$ desse núcleo, o aluno pode ingressar no núcleo avançado, optando por fazer disciplinas relacionadas à licenciatura ou ao bacharelado ou a ambas.
} 
prática" os saberes necessários para tal. Provavelmente, há outras necessidades partilhadas de se aprender algo na EB, porém não foram evidenciadas nas entrevistas ou visitas observadas.

É formada, então, uma comunidade - segundo elemento de uma COP - em torno dessa necessidade partilhada, na qual os membros da EB estabelecem um vínculo através do engajamento em torno de um domínio comum: aprender a se comunicar com o público. Os membros da EB se envolvem em atividades conjuntas, como a atuação em visitas, manutenção dos materiais vivos e não vivos da $\mathrm{EB}$, criação de novas atividades para visita, entre outras, gerando uma prática - terceiro elemento de uma COP - que culmina no desenvolvimento de um repertório compartilhado entre os membros da EB. Como exemplo de repertórios compartilhados por esses membros, tem-se o Manual de Sobrevivência, documento gerado pelos mediadores para reificar as práticas desenvolvidas na EB. Nesse documento, são encontradas diretrizes para atuação dos mediadores: conceitos, rotinas e ações pertencentes à EB.

Ainda para definir uma COP, Wenger e Snyder (2000) defendem que uma COP se diferencia de outras estruturas organizacionais quanto ao objetivo, à constituição dos membros participantes, ao que os mantém unidos e à duração. Pelo analisado, todas essas características atribuídas a uma COP são observáveis na EB. O objetivo da EB compreende desenvolver as competências dos participantes, gerar e compartilhar conhecimentos, como será mostrado posteriormente. Os participantes se auto selecionam, não há nenhuma intervenção da instituição para escolha dos membros da EB. Não possuem, tão pouco, um contrato. Os estudantes de Biologia escolhem participar da EB e permanecem lá até quando for necessário. Mantêm-se unidos pela paixão à biologia e ao compromisso existente por serem um grupo de extensão universitária e se identificam com os conhecimentos gerados na EB. E sua duração perdura desde 1986 até enquanto houver interesse em manter o grupo.

Além do exposto, outra forma de caracterizar a EB como uma COP foi verificar se os elementos engajamento mútuo, empreendimento conjunto e repertório compartilhado estão presentes, pois essas dimensões relacionam a prática ao termo comunidade (WENGER, 1998). Esses elementos serão analisados separadamente a seguir. 


\subsection{Engajamento Mútuo}

O engajamento mútuo compreende as ações realizadas em conjunto pelos membros da COP para desenvolverem a prática, o domínio, ou seja, o interesse em comum que os mantém unidos. Este elemento pode ser detectado através dos níveis de participação, das interações entre os membros, da ideia de pertencimento ao grupo e da identidade.

De acordo com Wenger (1998), participação está relacionada à filiação a uma comunidade, envolver-se, fazer parte de algo. Em uma COP existe uma diversidade de níveis de participação que variam da periferia até o centro, defendida por Lave e Wenger como a Participação Periférica Legitimada (LPP). A movimentação centrípeta (da periferia para o centro) dos participantes de uma comunidade acontece devido ao aumento do nível de participação e, consequentemente, do aumento da compreensão dos saberes necessários para o desenvolvimento da prática de tal comunidade.

Por meio da análise das entrevistas com os mediadores, foi possível detectar que a EB possui níveis de participação que variam do centro à periferia. Isso pode ser observado nas falas a seguir do mediador V1, o qual, também menciona a existência de dois centros na EB.

Turno 32: “... eu já tenho outra posição, já virei um membro velho, né (risos). Ele que é o elemento central (referindo-se a outro mediador). Administrativamente ele é central. Se pensar em termos de espírito do grupo, pode ser que eu ainda esteja nessa posição, mas administrativamente é ele. Coitado (risos)! É mais é essa coisa do velho, $n e ́ ”$. (Fala mediador V1).

Turno 138: "Mas tem veteranos assim que sempre foram periféricos ${ }^{16}$, mas se você perguntar alguma coisa ele vai saber responder. Mas ele nunca foi central”. (Fala mediador V1).

Apesar de não existir fisicamente um centro e uma periferia na COP, esses termos são utilizados para diferenciar o envolvimento dos membros ou o conhecimento desses sobre a prática desenvolvida na comunidade. Membros que não dominam a prática ou que tem um nível de envolvimento baixo ocupam a periferia (WENGER, 1998). Ao contrário, membros

\footnotetext{
${ }^{16}$ É necessário explicar que em nenhum momento foi comentado sobre a teoria de Comunidades de Prática com o mediador V1. O termo periférico utilizado nessa fala pode ter sido por conversas externas à pesquisa, como por exemplo, em leituras de textos e discussões nos Papos Pedagógicos (reuniões feitas pelos mediadores para discutir elementos teóricos e práticos do Ensino de Ciências).
} 
centrais são mais envolvidos e compreendem o cotidiano, as regras, os significados negociados e outras particularidades pertencentes à comunidade da qual fazem parte.

De acordo com Lave e Wenger (1991), uma participação plena pode sugerir um domínio fechado de conhecimento ou prática coletiva que pode fornecer degraus de aquisição de conhecimentos necessários para que os recém-chegados tornem-se membros centrais. Isso significa que participantes plenamente ativos (centrais) possuem conhecimentos que os novatos devem adquirir para se tornarem centrais também. Porém, isso acontece aos poucos, por isso a referência aos degraus. É importante salientar que nem todos os membros de uma COP precisam se tornar centrais, mas os membros centrais são essenciais para garantir a continuidade da COP, pois eles "facilitam os encontros entre gerações; jovens, recémchegados, intermediários e antigos" (MÔNACO, 2013).

Em relação à quantidade de centros existentes em uma COP, é plausível aparecerem vários. Inclusive, Lave e Wenger (1991) defendem a importância de a participação centrípeta não ser resumida a um único centro, já que pode haver mais de um expertise dentro de uma mesma comunidade. A própria diversidade dos níveis de participação pode gerar múltiplos centros para uma melhor organização da comunidade. Analogamente, se considerarmos uma família como uma COP, podemos ter o pai, a mãe e avós como vários centros desta comunidade. Na EB, o mediador V1 fala sobre dois polos centrais, um administrativo e outro relacionado às memórias e às referências do grupo ("Administrativamente ele é central. Se pensar em termos de espírito do grupo, pode ser que eu ainda esteja nessa posição...”).

A movimentação centrípeta nos níveis de participação também sofre influência da interação entre os membros de uma COP, pois a aprendizagem situada, defendida pelos criadores desse conceito é uma aprendizagem social, promovida pela troca de experiências (LAVE; WENGER, 1991). O esquema abaixo (Figura 05) foi baseado na ideia apresentada por Lave e Wenger (idem) e mostra as interações que podem ocorrer entre os membros de uma COP.

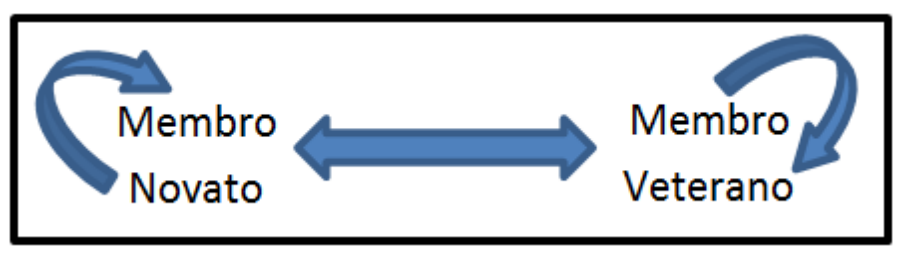

Figura 05. Interações entre membros de uma COP. 
De acordo com a figura 05, podem ocorrer interações entre membros veteranos e novatos, nas quais os primeiros auxiliam os segundos a aprenderem aspectos da prática da comunidade. Contudo, as interações dentro de uma COP não são limitadas a essa. Wenger (1998) defende que essa interação não é unidirecional, podendo acontecer de veteranos para novatos, de novatos para veteranos, de novatos para novatos e de veteranos para veteranos. Isso é possível, porque todos os membros, mesmo novatos, trazem experiências pertencentes à sua identidade, que podem ter sido aprendidas em outras comunidades de prática, e que serão úteis para o desenvolvimento da prática nas novas comunidades de que venham fazer parte.

Nessa perspectiva, o corpo de mediadores da EB é constituído por graduandos de biologia dos mais variados semestres e por uma diversidade de identidades, cada uma com histórico de vida e experiências diferenciadas que contribuem para as inúmeras possibilidades de interações mencionadas no parágrafo anterior. O interessante é que essa troca de experiências, possibilitada pela intensa interação entre os mediadores da EB, não ocorre de maneira forçada, não é algo programado. Pelo contrário, é algo que faz parte do cotidiano desses mediadores, pois eles mantêm uma relação de amizade e se ajudam em diversas situações, como na preparação e na execução das visitas, nas manutenções dos materiais da $\mathrm{EB}$, nos trabalhos e estudos para provas de disciplinas do curso de Ciências Biológicas, entre outras. Ao acompanhar à EB, foi possível detectar vários desses momentos. Durante a visita é comum presenciar, por exemplo, mediadores novatos prestando atenção na apresentação do veterano ou perguntando sobre alguma questão, ou ainda, algum veterano corrigindo alguma informação errada que o novato falou durante a apresentação. Além disso, durante as reuniões pós-visita, é feita uma avaliação pelos próprios mediadores e contribuições são levantadas, sugerindo como um determinado mediador deveria ter agido ou como deveria ter falado.

A fala a seguir do mediador N2 confirma que os veteranos orientam os novatos, sugerindo funções que eles possam ocupar nas primeiras visitas, por exemplo. No caso desse mediador, foi sugerido que ele ficasse controlando o tempo para observar como era o desenvolvimento da visita.

Turno 38: [Mediador N2]: Gostei. Foi legal participar. É... Eu fiquei numa coisa mais bastidores, mesmo. Eu fiquei contando o tempo. Ai, teve até aquela parte, acho que você tava na mesa comigo da parte da genética? Eu tava na mesa ali, dai eu falei um pouco com os alunos, expliquei algumas coisas e achei que foi, assim, um pouco... Ah... Qual a palavra? Foi divertido. 
Turno 39: [Entrevistador]: E o que você fez, foi escolha sua ou alguém colocou pra você fazer?

Turno 40: [Mediador N2]: O tempo?

Turno 41: [Entrevistador]: É.

Turno 42: [Mediador N2]: Então, foi escolha minha, mas foi sugestão também. Assim: "Ah, sua primeira visita, é mais legal você ficar observando". Tanto que eu fiquei, quando eu contei o tempo lá fora, eu fiquei ouvindo o que os outros monitores estavam falando pros grupos. Aí eu já tenho uma ideia do que eles costumam falar e como é a dinâmica. (Fala do mediador N1 na primeira entrevista).

Durante o acompanhamento que foi feito na EB para coleta de dados, verificou-se que alguns membros novatos, que inicialmente eram periféricos, depois de aproximadamente um ano e meio atuando como mediador da EB, passaram a ser centrais, tornando, a periferia, no caso desses mediadores, uma posição de empoderamento (LAVE; WENGER, 1991). Isso ficou evidenciado na comparação das duas entrevistas feitas com cada mediador novato. Os mediadores $\mathrm{N} 1$ e $\mathrm{N} 2$ passaram a se envolver mais nas atividades da EB e interagiram intensamente com outros mediadores, tornando-se centrais. Esse fato pode ser observado nas falas a seguir.

Turno 21: [Entrevistador]: Qual é a sua função lá na Estação Biologia? Você tem uma função específica ou... O que você fez até agora?

Turno 22: [Mediador N1]: Então, nas visitas eu tava controlando o tempo, pelo menos a última eu controlei o tempo em si. Só que pra projetos, por exemplo, eu tô me focando, juntamente com a... Aí eu não sei o nome dele, sei que é o mediador N2 o apelido dele... A gente tá fazendo um projeto pra poder passar o ensino de cantos de aves pra crianças. Estamos tentando fazer algum projeto assim, com teatro, fantoches. Ainda tá nebulosa a ideia, mas tá surgindo. E eu e outra integrante, a gente tá fazendo, montando uma atividade com... Pra ensinar abelhas pra crianças do ensino... Crianças não, pré adolescentes do Ensino Médio ou do Fundamental II. E também, tô no desafio e tá no começo também. E, o resto é tipo, as atividades do dia a dia, a gente vai preenchendo ne. Mas o principal tá sendo esse. [...]

Turno 33: [Entrevistador]: E, a sua função, você falou, foi de contar o tempo.

Turno 34: [Mediador N1]: Uhum. 
Turno 35: [Entrevistador]: Você que escolheu isso ou alguém sugeriu que você fizesse?

Turno 36: [Mediador N1]: Não, eu que escolhi, porque eu não queria me expor muito. Eu queria só observar mais e essa é uma função que você mais observa e atua menos. Turno 37: [Entrevistador]: Por que você queria só observar?

Turno 38: [Mediador N1]: Porque eu tô meio inseguro ainda, por eu estar começando agora. Mas mais pra frente eu vou querer fazer outras coisas. (Fala do mediador N1 na primeira entrevista).

Turno 26: [Entrevistador]: Entendi. E... Qual é a sua função na EB?

Turno 27: [Mediador N1]: Bom, como bolsista agora, eu tô na função de relações internas, um RH. Então, basicamente eu tento integrar todas as comissões. Integrar as pessoas internamente. Então, eu tô na comissão de quinta e sexta, tento integrar essas duas. Mas também, eu sempre tento estar presente nas outras comissões pra poder saber o que está acontecendo em cada uma, como tá o desenvolvimento pessoal de cada monitor e... Fazer o bate bola entre eles e ter a visão geral do que ocorre dentro da EB. É... Eu também organizo as reuniões, ne, que eu acho que tendo essa visão geral da EB, eu posso organizar as reuniões e, também, apontar os principais defeitos pra poder orientar a galera quais são os próximos passos internos da EB. Relações internas. (Fala do mediador N1 na segunda entrevista).

Turno 29: [Entrevistador]: No caso, qual é a sua função na estação biologia? O que você fez até então? Tem alguma função específica?

Turno 30: [Mediador N2]: Não, não tenho função específica ainda. Ainda não fiz nenhuma das manutenções. Eu tô marcada pra fazer isso no final do mês. Ai, eu não tenho uma função assim. Por enquanto, eu só pensei numa atividade aí, dei uma pincelada. (Fala do mediador N2 na primeira entrevista).

Turno 19: [Entrevistador]: Qual a sua função na EB agora?

Turno 20: [Mediador N2]: Então, agora eu tô como bolsista né, e ai eu fiquei com o departamento assim. É porque a gente dividiu mais ou menos assim. Não quer dizer que você só faz isso ou que outras pessoas não podem fazer a função do seu 
departamento também. É... Mas eu fiquei com o departamento de coordenadoria pedagógica assim. Então seria mais ou menos o que a pessoa que incentiva o pessoal a produzir novas atividades e ver onde que elas estão ne. Pra não acontecer de uma atividade ficar no limbo. É... Começar fazer e depois todo mundo desistir porque não era uma ideia tão boa assim. Então, saber encaminhar isso ne. (Fala do mediador N2 na segunda entrevista).

Pode-se analisar nessas falas que ambos mediadores viraram bolsistas e passaram a ocupar posições centrais. Vale mencionar que foi estabelecido, pelos membros da EB, que cada mediador pode ficar como bolsista no máximo dois anos. Quando acaba a vigência, os próprios bolsistas selecionam quem irá substituí-los, seja através de entrevista ou através de identificação de perfis, como indicam as falas abaixo dos mediadores V2 e N3.

Turno 85: [Mediador V2]: Então é uma coisa muito assim, por exemplo, tenho pessoas em vista sim que acho que tem potencial pra virar o centro e é muito informal assim, você chega na pessoa e "olha tá a fim de..." como a gente fala: de pegar essa parada (risos), de olha eu acho que tu leva jeito e tal e acontece, eu acho que não é por votação, não é assim alguém que vira e fala eu quero, pelo menos nunca aconteceu, olha eu gostaria de me inteirar mais nisso e tal, eu acho que acontece naturalmente é... Quando a gente tá trabalhando a gente percebe que tem algumas pessoas que se destacam também, nossa essa pessoa tem muito perfil assim pra firmar um esquema dá um role assim, vai dar certo. Daí, normalmente, você chega e fala "e ai?". Foi, por exemplo, que aconteceu comigo assim com o Mediador V1. Tipo, ele percebeu que eu levava jeito pra coisa dai meio que sempre foi assim: "tá a fim de me ajudar nisso que eu tô fazendo?" Eu ia lá e ajudava. Ah "tá a fim de me ajudar nisso?" E quando você vai ver você está envolvido e acho que sempre aconteceu assim e é o que estou fazendo agora com o Mediador C (risos). Tipo me ajuda nisso não sei o que, e eu acho que tenho esse potencial pra firmar isso também. É muito informal. (Fala do mediador V2).

Turno 39: [Entrevistador]: E por que você não quis tentar ser bolsista? Como isso funciona? 
Turno 40: [Mediador N4]: Então, num momento eu quis, mas eu não passei na entrevista e depois dessa primeira tentativa eu não tentei mais ser bolsista porque eu fiquei "ah, dane-se". Vou ficar aqui na minha.

Turno 41: [Entrevistador]: Quem faz a entrevista?

Turno 42: [Mediador N4]: Os bolsistas.

Turno 43: [Entrevistador]: Os bolsistas antigos entrevistam os novos?

Turno 44: [Mediador N4]: Isso. E ai, é... O pouco que eu sei de como isso acontece é que eles procuram... Eles têm perfis, ne, de pessoas. Por exemplo, precisa de uma pessoa sistemática pra ser a pessoa que vai cuidar do patrimônio, entendeu? Eles vão vindo por perfis de pessoa ai se sai uma pessoa de patrimônio, tem que ter uma pessoa com mesmo perfil que ela. Mas... Eu não sei direito (risos). (Fala do mediador N3 na segunda entrevista).

Pelo fato de existir uma bolsa, os mediadores que a recebem possuem a obrigatoriedade de participar de duas comissões, fazer o dobro de manutenções e resolver particularidades burocráticas da EB. Tendo isso em vista, a bolsa pode ser um fator importante na EB para gerar maior envolvimento. Esse maior envolvimento dos bolsistas, traz como consequência o domínio da prática desenvolvida pela $\mathrm{EB}$, tornando esses mediadores expertises, ou seja, centrais. Isso aparece nas falas dos mediadores N3 e N4, quando eles comentam que existe uma hierarquia em que os bolsistas estão em um patamar acima dos voluntários, tendo, inclusive, mais poder de decisão.

Turno 49: [Entrevistador]: E pra terminar, você enxerga algum centro da Estação Biologia? Alguma pessoa como centro ou algumas pessoas como centro da Estação Biologia?

Turno 50: [Mediador N3]: Bem, acho que os RDs sempre acabam sendo um centro assim, mesmo que eles tentem não ser, eles acabam sendo, porque são pessoas que estão mais inteiradas aqui dentro ne. Elas participam de duas comissões, elas fazem a parte burocrática daqui, então acaba ficando um pouco mais...

Turno 51: [Entrevistador]: Os RDs são os bolsistas?

Turno 52: [Mediador N3]: Isso. (Fala do mediador N3 na segunda entrevista). 
Turno 26: [Mediador N4]: [...] Agora, um ponto negativo. Eu não sei. Mas eu diria que, às vezes... É... Sei lá. A EB tem alguns vícios em que ela... Ao mesmo tempo em que ela se mostra é... Permissiva pra tentar coisas novas em relação às atividades, ela, às vezes, não quer mudar a estrutura dela. Por exemplo, um pouco antes de eu sair tinha... Teve reuniões gerais em que a gente propôs reinventar o sistema de manutenções e tal. E ai o pessoal não quis mudar. Simplesmente porque ah, não vai dar certo. Tipo, não quis nem tentar. E ai... Eu senti isso pô, mas se vocês querem experimentar nas atividades, não querem experimentar na estrutura do negócio ne? Então, tem uma certa rigidez assim. E isso em parte é porque, acho que o pessoal cria as hierarquias baseada em que é bolsista e quem não é. Tipo, as pessoas que são bolsistas são mais ouvidas na reunião. Eu percebi isso assim. Por mais que esse não tenha sido o intuito, inclusive os bolsistas vivem falando que isso não procede, $o$ pessoal não tá nem aí. Eles criam essa hierarquização na cabeça deles.

Turno 27: [Entrevistador]: Você acha que os bolsistas, então, eles estão num patamar acima do que aqueles que são voluntários?

Turno 28: [Mediador N4]: Então, não é que eles estão num patamar acima. O pessoal que não é bolsista bota eles lá, entendeu? Tipo, com o tempo, como eles vão fazendo mais coisas, eles estão mais por dentro, eu acho que acaba criando esse negócio de que, mesmo que eles não queiram, eles são botados como... Numa hierarquia, pra cima assim, entendeu? E ai, tipo exemplo, é... E também esse negócio também acontece com quem tá muito tempo. $\underline{O}$ mediador VI uma vez me comentou isso. Que só pelo fato de ele estar lá na EB há 4, 5 anos, ele era mais ouvido. E por mais que ele faça uma besteira, todo mundo ia ouvir ele. Só porque é velho. Entendeu? (risos). Então, claro que isso é meio que inerente a EB ne. Das pessoas, mas... Esse, eu acho que esse é o maior problema de lá. De ficar dando é... Hierarquizando demais as coisas, no fim a opinião pessoal de um acaba sobressaindo sobre o que a gente deveria ou não tentar. (Fala do mediador N4 na segunda entrevista).

Outra evidência de engajamento mútuo aparece nas falas referentes à identidade dos mediadores, como habilidades e competências frente às atividades desenvolvidas, o percurso histórico de cada mediador antes de entrar na EB, preferências de público visitante, de conteúdos, entre outros. 
Parágrafo 2: “É... por causa do meu vô. Olha só... o meu vô gostava muito de plantas, ele tinha quintal que eu cuidava dele, o quintal, e eu me interessei. Eu... gosto mais de plantas do que de biologia. (risos) E eu já tinha interesse em ser professor e eu precisava de alguma disciplina né, pra ser professor." (Fala do mediador V1).

Parágrafo102: “... eu acho que eu sou bom pra estruturar o negócio. Eu não sou bom pra fazer, mas (risos) pra estruturar, pra organizar "ó pessoal vamos pensar, sentar e pensar... Objetivos, tal”. Isso acho que é legal. E como é autogestão, o negócio precisa muito de estruturação cuidadosa. Isso ai acho que eu dou uma ajuda". (Fala mediador V1).

Parágrafo 77: “É... eu diria que assim, modéstia parte, eu tenho uma habilidade, que eu acredito ser bastante forte, de falar em público e eи acho que isso ajudou muito a passar pros outros monitores os objetivos da Estação Biologia. No treinamento pros meus bichos, acho que contribui bastante nesse sentido. Acho que é a eloquência que eu tenho, eles se identificaram bastante, eles conseguiram pegar bastante coisa. Eu sou uma pessoa que me considero bastante organizado com relações em... sei lá, com a burocracia, por exemplo. Então, eu acho que por isso eu acabei centralizando tanta coisa assim, porque eu me considero bastante organizado e eu gosto muito do envolvimento com o público. Isso é uma coisa que sempre gostei, sempre gostei de conversar, de falar, de... sempre fui muito expressivo. Então, acho que assim foi, talvez de longe, a principal característica que contribuiu pra que eu me desse tão bem aqui na Estação Biologia”. (Fala do mediador V2).

Parágrafo 63: Eu prefiro os maiores. Então assim, é... Ensino médio e ensino fundamental assim 2 (risos)... eu prefiro os maiores é...eu acho que sei lá eu julgo assim que eles tem maior facilidade de entender, ai às vezes até me questiono, será que não é uma deficiência minha não saber passar pros menores ou algo assim. É... E eu acho que por eles serem mais velhos me permite fazer aquilo que falei que eu gosto de ter tom da brincadeira, o tom da diversão, eu não sei muito bem como aplicar isso com crianças assim, entendeu? E com muitos muito novinhos. E acho que até é uma questão (risos)... Não tenho paciência com os “catatauzinhos", mas tem monitor, por exemplo, que adora sabe? Prefere mil vezes numa visita pra fazer abelhudo com 
criancinhas que às vezes usa chupeta, sabe, do que os mais velhos assim. Eu não sei eu gosto dos mais velhos eu acho que... nunca tive problemas com eles. (Fala do mediador V2)

A identidade é uma característica muito importante do engajamento mútuo, pois ela influencia a maneira como o indivíduo se engaja na comunidade. Wenger (1998) defende que a unidade para análise da identidade de uma COP deve ser a comunidade e cada membro participante, sem desvinculá-los, pois o processo de construção dessa identidade engloba aspectos sociais e individuais. Falar sobre identidade social não é negar a individualidade, mas ver a definição de individualidade como parte da prática de comunidades específicas (Ibid). O autor ainda completa informando a dificuldade em identificar a delimitação entre a esfera do individual e do coletivo.

De acordo com Wenger (1998), a construção da identidade social de uma COP inclui a interação entre os membros para que nesse processo as identidades individuais passem por um processo de negociação. Wenger (1998) atenta, porém, para o fato de que os membros de uma COP não precisam concordar com tudo o que é praticado ou reificado. E isso é importante, pois a identidade de cada indivíduo da COP torna-a heterogênea e, consequentemente, um local rico para compartilhamento de experiências e conhecimentos e é o engajamento mútuo o responsável por juntar essa diversidade numa mesma prática.

Para que um membro de uma COP consiga analisar como é sua experiência na prática da comunidade, como interpretar sua posição, o que entender sobre o que faz, sobre o que sabe e o que não sabe são necessárias escolhas individuais e coletivas (WENGER, 1998). De acordo com Mônaco (2013), a escolha entre participar ou não de atividades e de obter novos conhecimentos dependerá do quanto à identidade individual está aberta a experimentar uma nova visão de mundo. Dessa forma, a identidade individual é responsável pela maneira como a pessoa se dispõe para execução da prática. A identidade é uma das responsáveis pelo nível de participação que o membro desenvolverá na COP.

Isso explica, por exemplo, porque o mediador N3 não se tornou central como os mediadores N1 e N2. Na fala a seguir, o mediador N1 reconhece a competência do N3 e mostra quais os possíveis motivos de o mediador N3 não ser central.

Turno 66: [Entrevistador]: E o mediador N3, qual o ponto forte dele? 
Turno 67: [Mediador N1]: Ai caramba (risos). Ninguém tá vendo ne (risos). Ponto forte do mediador N3? (Pausa) É... Ele é comprometido.

Turno 68: [Entrevistador]: É comprometido?

Turno 69: [Mediador N1]: É... É o que fez ele tá até hoje com a gente ne. Ele é comprometido, bastante. Eu tenho pouca experiência de, de... Visitas com ele. Eu não sei como ele é na didática, na participação da didática. Mas ele tem... Ele é uma pessoa que eu posso contar, entendeu.

Turno 70: [Entrevistador]: E... Mas por que é... Por exemplo, vocês entraram juntos. Você, o mediador N2 e o mediador C viraram bolsistas. E por que o mediador N3 não virou bolsista?

Turno 71: [Mediador N1]: Humm... (Pausa). Ah, eu diria que ele... Que ele... Ele tem o comprometimento devido, adequado de todo monitor, mas eu acho que ele não queria muitas responsabilidades... Perante a EB. É... Eu acho que ele teria... Queria fazer outras coisas também ne. Não ficar tão, tão atolado em cargas ne. E ele também tá... É do integral. Tudo bem, o mediador N2 também é do integral, mas... Se eu fosse do integral, eu pensaria duas vezes antes de ser um bolsista. É... Eu sou do noturno no caso. Então, eu acho que ele tem as prioridades dele ne." (Fala do mediador N1 na segunda entrevista).

A ideia de pertencimento também é um elemento componente da identidade dos membros de uma COP que influenciará o engajamento de cada um. Um indivíduo que se considera pertencente a uma COP se sente familiarizado com as práticas e conceitos desenvolvidos na mesma e, por isso, consegue identificar as próprias competências/habilidades e a dos outros membros, os pontos fortes e fracos da comunidade, questionar e sugerir novas metodologias ou novos conceitos. "Genericamente pode-se dizer que ser um membro numa comunidade de prática se traduz em assumir uma identidade como uma forma de competência" (MÔNACO, 2013, p.45). Um membro que se enxerga pertencente a uma COP assumirá responsabilidades para o desenvolvimento do empreendimento conjunto. Isso pode ser mais um fator para promover o empoderamento deste membro, resultando na sua movimentação centrípeta. Exemplo disso é o que aconteceu 
com o mediador N2, o qual se tornou um membro central e cuja ideia de pertencimento ${ }^{17}$ à EB pode ser detectada na fala abaixo.

Turno 5: [Entrevistador]: E por que você decidiu continuar na EB?

Turno 6: [Mediador N2]: Então, porque eu fui me envolvendo muito, assim, e eu senti que eu estava fazendo parte daquilo e que eu estava gostando do resultado. Eu gosto de ver a EB andar. Eu gosto de ver as coisas acontecendo e você pegar um projeto novo pra fazer e montar atividade e aplicar e ver que ela dá certo, sabe? Acho que é... É por isso, assim. É por ver que você investe o seu tempo e sua energia e o negócio dá certo assim. O negócio sai. (Fala do mediador N2 na segunda entrevista).

Do contrário, aquele que não se sente pertencente, que não consegue harmonizar sua identidade individual à identidade coletiva da comunidade, tende sair dela. É o que pode ter acontecido com o mediador N4, cuja fala a seguir mostra que ele queria estabelecer outras prioridades e que não é de acordo com o papel hierárquico atribuído aos bolsistas pelos próprios mediadores voluntários, característica essa pertencente à EB.

Turno 37: [Entrevistador]: Legal. Por que você saiu da EB?

Turno 38: [Mediador N4]: Sai por duas coisas. Uma porque... Ia começar a apertar meu horário. Eu decidi, por isso, "ah, eu vou ficar mais no estudo em... No que eu quero, que é seguir em ciência mesmo. Por mais que eu tenha adorado a EB, eu gosto muito de educação, eu gosto de ciência (risos). Ai, eu decidi focar mais nisso a partir de agora e eu no fundo eu tinha refletido que se eu fizesse um bom esforço eu conseguiria continuar na EB, só que ai eu saia fazendo isso em detrimento do que eu poderia fazer, largando a EB e ao mesmo tempo eu tava já naquele negócio de... Eu tava meio crica já com esse negócio que eu apontei de que a EB tem essas rigidezes ai e eu já tava começando a ficar cansado disso. De pô, fulano... (Fala do mediador N4 na segunda entrevista).

Ainda analisando o caso do mediador N4, foi mencionado anteriormente que a existência de uma bolsa financiadora pode ser uma geradora de maior envolvimento e,

\footnotetext{
${ }^{17}$ É importante ressaltar que essa ideia de pertencimento do mediador N2 foi um dos fatores que pode ter contribuído para sua movimentação da periferia ao centro. Isso porque, para que essa movimentação ocorra são necessários outros quesitos como envolvimento, compreensão de conceitos e práticas da comunidade e identidade do mediador.
} 
consequentemente, de maior engajamento. Contudo, esse fato apresenta outro viés: o da desmotivação. De acordo com a entrevista feita com o mediador N4, ele tentou ser bolsista, mas não passou no processo seletivo feito pelos bolsistas vigentes. Isso pode ter colaborado para o estabelecimento de novas prioridades pelo mediador N4, ou ainda, pode ter influenciado a ideia de pertencimento desse mediador, ocasionando sua saída.

Turno 39: [Entrevistador]: E por que você não quis tentar ser bolsista? Como isso funciona?

Turno 40: [Mediador N4]: Então, num momento eu quis, mas eu não passei na entrevista e depois dessa primeira tentativa eu não tentei mais ser bolsista porque eu fiquei "ah, vou ficar aqui na minha".

Turno 41: [Entrevistador]: Quem faz a entrevista?

Turno 42: [Mediador N4]: Os bolsistas.

Turno 43: [Entrevistador]: Os bolsistas antigos entrevistam os novos?

Turno 44: [Mediador N4]: Isso. E ai, é... O pouco que eu sei de como isso acontece é que eles procuram... Eles têm perfis, ne, de pessoas. Por exemplo, precisa de uma pessoa sistemática pra ser a pessoa que vai cuidar do patrimônio, entendeu? Eles vão vindo por perfis de pessoa ai se sai uma pessoa de patrimônio, tem que ter uma pessoa com mesmo perfil que ela. Mas... Eu não sei direito (risos).

Turno 45: [Entrevistador]: Entendi.

Turno 46: [Mediador N4]: Afinal quem faz os critérios são eles (risos). (Fala do mediador N4 na segunda entrevista).

Em resumo, o engajamento é o resultado da movimentação centrípeta nos níveis de participação, da identificação do membro como pertencente a tal comunidade, da intensa interação entre os membros e da identidade individual e coletiva voltadas à prática da COP. Sem esses itens, os membros tendem a elencar outras prioridades e não estabelecem vínculo suficientemente forte para se manter atuantes na comunidade.

\subsection{Empreendimento Conjunto}

O empreendimento conjunto é resultado de um processo de negociação de significados que reflete a complexidade do engajamento mútuo (WENGER, 1998). Para se identificar tal 
elemento nas falas dos mediadores, procurou-se encontrar características como o objetivo em comum do grupo, responsabilidade mútua, significados negociados ou em negociação pelos membros da EB.

Através do objetivo comum podemos identificar o que os membros da EB fazem ou entendem o que fazem juntos, caracterizando o empreendimento conjunto da EB. A partir das falas dos mediadores entrevistados, nota-se que a forma como os mediadores centrais e os periféricos enxergam esse objetivo é diferente.

Os mediadores periféricos identificam que a $\mathrm{EB}$, por ser um projeto de extensão universitária, tem por objetivo disponibilizar para a sociedade uma forma prática e lúdica de se aprender biologia.

Turno 54: [Mediador V3]: Acho que é uma forma diferente de ensinar. Você foge... A gente usa a lousa, mas de uma forma diferente. Não fica aquele... Copia da lousa, com o professor o tempo todo. E também a própria didática é assim mais visual. Você pega o bonequinho, você monta o bonequinho, você vê acontecer. É diferente de falar vai pra lá, vai pra lá e pronto, chega disso daqui. Acho que faz diferença assim, por ser visual, por ter o contato. Tanto que eu não gosto de atividades que usam muito a lousa, acho que mais entediante e lembra muito mais o colégio do que uma atividade paralela. (Fala do mediador V3)

Turno 44: [Mediador N3]: Humm... Meio que mostrar pras crianças e adolescentes que vem aqui mais como é a profissão de um biólogo. Porque tem aquela visão muito: mexer só em bicho, ficar se metendo no meio do mato. E não é só isso, ne. Acho que é também, ensinar coisas diferentes com outros meios. (Fala do mediador N3 na primeira entrevista)

Turno 68: [Mediador N4]: Educar de forma lúdica (risos) a biologia, assim. Ensinar uma forma diferente do que as crianças aprenderiam em sala de aula. (Fala do mediador N4 na primeira entrevista)

Já os mediadores centrais, enxergam mais que isso. Eles concordam com o papel de divulgação científica da EB evidenciado pelos periféricos, mas também compreendem que a EB é um local de formação de mediadores. 
Turno 76: [Mediador V1]: [...] Eu cheguei nisso ne, objetivo da EB, o primeiro seria atender crianças ne, ou seja, atender alunos e com muitas aspas promover crescimento neles, com muitas aspas. O segundo objetivo ne, menos importante, tão importante, mas menos do que o primeiro, segundo seria formar monitores, e acho isso...E o terceiro objetivo que é bem obscuro e esse é bem pessoal é ser um núcleo da licenciatura na biologia. Oh que maluco (risos). Mas isso é porque eu gosto de licenciatura né. (Fala do mediador V1)

Turno 69: [Mediador V2]: Hum... Essa é uma boa pergunta, por muito tempo eu achava que o objetivo da Estação Biologia era principalmente receber visitas e fazer extensão é... Passar conteúdo, mas hoje eu acho que o principal pra mim que eu considero mais importante é formar monitores. (Fala do mediador V2).

O mediador N1 que, na primeira entrevista, ocupava a periferia da EB por ser novato, possuía uma definição do objetivo da EB que foi alterada, provavelmente, pelo seu crescente nível de engajamento. Isso pode ter sido um dos fatores que contribuiu para que ele assumisse uma posição central, pois o seu nível de engajamento permitiu que ele compreendesse que a $\mathrm{EB}$, além de ser um espaço de extensão universitária e, consequentemente, de divulgação científica, é também um local para gerar e compartilhar conhecimentos relativos à formação de mediadores, aproximando-se, assim, das respostas dadas pelos mediadores V1 e V2.

Turno 42: [Mediador N1]: Essencialmente é repassar tudo aquilo que a gente tem obrigação de repassar para a sociedade, que elas pagam pra gente todo dia. É, eu acho que todo aluno da USP tem que ter essa noção. Você tá aqui não é simplesmente pra você fazer sua carreira e ganhar seu dinheiro. É você repassar isso de alguma forma pra sociedade. Eu tô fazendo biologia não é simplesmente pra ganhar dinheiro, mas sim porque é uma área que eu adoro e eu posso repassar para as pessoas de certa forma. Dinheiro é consequência. Mas eu já me conformei, não serei rico (risos). (Fala do mediador N1 na primeira entrevista)

Turno 53: [Mediador N1]: Tá. São basicamente três objetivos que eu vejo que a EB tem. Eu já esqueci um, mas tá. Primeiramente, é... Formar monitores, fazer futuros 
educadores. Então, os monitores, os graduandos daqui eles perdem... Aquela questão de perder mais a vergonha de falar em público, ter mais clareza na didática, é... Ser futuros professores, mesmo. Eu diria o segundo objetivo da EB é... Fazer materiais, materiais didáticos. Então, se a gente não tá fazendo visita, a gente tá fazendo comissão. Então, na comissão é... Eu acho que a gente tem que trabalhar na criação de atividades e metodologias de ensinar uma coisa que já tem no currículo básico da escola, só que de maneiras diferentes, de maneiras mais práticas, mais divertidas, mais didática. Criação de atividades e materiais de atividades. E o terceiro objetivo seria... A transformação do próprio aluno que vem visitar. Ele ganhar não só uma carga de conteúdo quando vem aqui, mas também ganhar uma carga emocional. É... Fazer ele... Criar esses momentos de, de... De visita. Fazer com que eles se vislumbrem com a visita e assim, não, necessariamente, formar novos biólogos ne, a partir dessas crianças, desses adolescentes. Mas formar pessoas que tem noção disso que... Que não ignorem a biologia como uma coisa a parte, como uma coisa chata, uma coisa reservada só para os biólogos né. E plantar um pouco de biologia neles. (Fala do mediador N1 na segunda entrevista)

O mediador N2, por sua vez, apresentou falas semelhantes em relação ao objetivo da $\mathrm{EB}$, tanto na primeira, quanto na segunda entrevista e essas falas são próximas ao elucidado pelos mediadores $\mathrm{V} 1, \mathrm{~V} 2$ e N1. Isso pode ter ocorrido pelo fato de este mediador ter um grau de envolvimento elevado desde o início.

Turno 44: [Mediador N2]: Hum... Acho que... Tanto fazer uma coisa para a comunidade, porque as escolas vêm e todos os visitantes vão levar alguma coisa daqui ou pelo menos é o que a gente espera ne. Então uma coisa de divulgar mesmo, mais cultura assim, mais informação. Mas eu acho que é um aprendizado pra todo mundo que participa. Pra todos os monitores. Eu diria que talvez mais do que trazer uma coisa pra sociedade, eu vejo como se fosse um laboratório, fosse um aprendizado pro pessoal que tá aqui. Porque tudo isso que a gente tá fazendo é ganhar experiência. E depois quando sair daqui isso vamos levar com a gente e lógico que tem um retorno pra sociedade. É então eu acho que é meio mútuo (risos). (Fala do mediador N2 na primeira entrevista) 
Turno 14: [Mediador N2]: [...] No final das contas não dá pra fugir muito dos objetivos da EB, sabe, porque é isso assim. Tá ali na raiz da coisa. Então, é... Criar, como fala? Formar monitores, ne. Afinal de contas, a gente muda muito assim. Eu vejo que eu mudei muito desde que eu entrei até agora. E... Sei lá. Formar... Trocar com o público assim, sabe. Através dessas atividades ne, e bolar atividades novas, passar esse conhecimento. Eu lembro que quando você me perguntou, você até falou assim: "você acha que o objetivo principal da EB é qual? É formar os monitores ou é receber visitas?" E eu acho, eu continuo achando assim, que é formar monitores, entendeu. Porque... Claro que é muito importante uma criança que tá na escola pública e nunca tem laboratório, nunca viu nada. Ai ela vem aqui vê um bicho vivo, um bicho no álcool. Pode pegar. É uma experiência pra vida e tudo mais. Acho que é muito importante, mas... Você entende o que eu quero dizer?

Turno 15: [Entrevistador]: Sim

Turno 16: [Mediador N2]: Tipo, a gente tá aqui, daí a gente vai pra fora, algum dia. Turno 17: [Entrevistador]: Claro.

Turno 18: [Mediador N2]: E com isso, a gente vai levar essa experiência com a gente. Pelo menos, é isso que eu gostaria. Então, acho que é isso. É um espaço de formação, espaço de troca e... É... (risos). (Fala do mediador N2 na segunda entrevista)

As definições do objetivo da EB dos mediadores N3 e N4 não se alteraram na segunda entrevista, em relação à primeira, e não se aproximam das falas dos mediadores V1, V2, N1 e N2. Isso pode ter ocorrido porque esses mediadores (N3 e N4) mantiveram um nível de participação mais periférico, ou pode evidenciar uma limitação de interação entre os membros da EB para negociação desse significado.

Turno 24: [Mediador N3]: É retribuir um pouco daquilo que a gente recebe da sociedade. Como a gente sempre diz aqui. A gente recebe os impostos, então é uma forma de retribuir, além de mostrar um... Um lado diferente da biologia pros alunos ne. Porque na sala de aula eles têm muito daquela coisa de só matéria, só matéria e lousa ne. Às vezes, passa pro vídeo, mas é muito rara às vezes. E aqui você tem uma forma mais lúdica ne. Uma forma mais pegável assim da biologia. E... Geralmente, eles acabam gostando mais. Alunos que tem desempenho muitas vezes ruim na sala, as professoras falam que aqui eles mostram um conhecimento que elas não esperavam 
que eles tivessem. Devido ao... À forma como eles se comportam na sala de aula. (Fala do mediador N3 na segunda entrevista)

Turno 24: [Mediador N4]: Objetivo da EB? É... Ensinar de uma maneira... Ensinar as mesmas coisas que eles poderiam aprender na sala de aula só que de uma maneira diferente. E, portanto, essa... Esse diferencial, de não estar na sala lendo livro, isso torna eles mais propensos a aprender ou a... Principalmente, acho que isso se enquadra mais no caso de criança mais nova. Eles divertindo, enquanto eles aprendem, eles podem associar essa parte boa de brincar onde... Ou de mexer com as coisas com o aprender. Isso pode fazer com que no futuro eles estejam mais é... Abertos a aprender. Isso é o que eu acho que é o objetivo da EB. Propiciar essa diferença e, ao mesmo tempo, essa... É... Criar esse sentimento bom de aprender algo. Acho que esse é o objetivo. (Fala do mediador N4 na segunda entrevista)

Apesar de as falas dos mediadores V1, V2, N1 e N2 terem pontos similares quanto ao objetivo da EB, podem ser observados dois momentos. No primeiro momento, no qual os mediadores V1 e V2 ainda ocupam uma posição central na EB, a definição do principal objetivo encontra-se em processo de negociação.

Turno 76: [Mediador V1]: Olha só (risos). É... Essa é uma boa pergunta. Ano passado eu tava em crise com relação a isso e até convoquei os veteranos de 2006, chamei um de 2004 e... Só os veteranos né, bicho não são a fim de ir. Mas teve uma reunião assim, que eu falei: galera, qual que é o objetivo da EB né? Eu não sei o objetivo, eu to aqui um tempo e não sei. E eu falei: vocês sabem? Eu perguntei pra eles. E foi uma dia que nossa, sai de lá arrepiado. Foi bonito. Eu senti que os veteranos tinham esse objetivo na cabeça. Eu que não tinha né. Eles sempre me passaram, mas não me convenciam. Eu perguntei, pô, qual é o público preferencial da EB? A forma que a gente se organiza, ela é boa? Ou seja, entre alunos e tal. A estrutura da EB tipo, é válida para os alunos? Não seria mais fácil fechar a EB $e$ destinar a verba que a gente ganha pra Estação Ciência? Eu perguntei isso, na cara assim ne. Qualé que é né? E eu peguei também... Isso foi uma madrugada que eu não dormi. Eu peguei um papel e, eu sou muito cartesiano ne, então eu gosto de estabelecer prioridades, se a gente fosse pensar em três objetivos ne, da EB, qual 
seriam eles e tipo ranquear. E depois eu fiz e discuti com o pessoal. (Fala do mediador V1)

Turno 82: [Mediador V1]: E quando a gente estava discutindo objetivos ne, é...eu cheguei lá na EB com esse papelzinho e falei: oh galera, eu acho que o objetivo primordial é a formação de monitores, e o role dos alunos é secundário. Eles me convenceram que eu tava errado.

Turno 83: [Entrevistador]: De que primeiro é essa parte dos alunos.

Turno 84: [Mediador V1]: Exato. (Fala do mediador V1)

Turno 69: [Mediador V2]: Hum... Essa é uma boa pergunta, por muito tempo eu achava que o objetivo da Estação Biologia era principalmente receber visitas e fazer extensão é... Passar conteúdo, mas hoje eu acho que o principal pra mim que eu considero mais importante é formar monitores. (Fala do mediador V2)

Sobre essa dualidade em relação ao objetivo da EB, Wenger (1998) defende que o empreendimento conjunto é definido pelos participantes no próprio processo de construí-lo. Ele é o resultado da negociação de significados.

No segundo momento, no qual os mediadores N1 e N2 passam a ocupar uma posição central na EB, a definição do objetivo principal parece estar estabelecida, parece ter passado para o estágio de significado negociado pelos membros da EB, pois os dois enxergam a formação de mediadores como objetivo primordial.

Turno 53: [Mediador N1]: Tá. São basicamente três objetivos que eu vejo que a EB tem. Eu já esqueci um, mas tá. Primeiramente, é... Formar monitores, fazer futuros educadores. Então, os monitores, os graduandos daqui eles perdem... Aquela questão de perder mais a vergonha de falar em público, ter mais clareza na didática, é... Ser futuros professores, mesmo. (Fala do mediador N1 na segunda entrevista)

Turno 14: [Mediador N2]: [...] No final das contas não dá pra fugir muito dos objetivos da EB, sabe, porque é isso assim. Tá ali na raiz da coisa. Então, é... Criar, como fala? Formar monitores, ne. Afinal de contas, a gente muda muito assim. Eu 
vejo que eu mudei muito desde que eu entrei até agora. [...] E eu acho, eu continuo achando assim, que é formar monitores, entendeu. [...]

Turno 18: [Mediador N2]: E com isso, a gente vai levar essa experiência com a gente. Pelo menos, é isso que eu gostaria. Então, acho que é isso. É um espaço de formação, espaco de troca e... É... (risos). (Fala do mediador N2 na segunda entrevista)

Esse processo de formação de mediadores da EB elucidado pelos mediadores V1, V2, N1 e N2, pode ser analisado, de acordo com o estudo da Marandino (2008, descrito no primeiro capítulo desta dissertação, p. 21), como sendo centrado na prática, na relação aprendiz-mestre e na auto formação, já que a ação de mediar é aprendida durante a prática, os mediadores novatos aprendem observando os veteranos e o mediador utiliza de suas experiências, leituras e de seu conhecimento para elaborar estratégias de ação. Isso fica evidenciado na fala do mediador V2.

Turno 52: [Entrevistador]: Então! E no caso você, tenta pensar e lembrar um pouquinho como foi a sua... A construção da sua fala? Na sua visita, lá que você tá lá na frente. Como é que você construiu essa fala?

Turno 53: [Mediador V2]: Tá! A princípio é... Quando a gente apresenta uma primeira vez, eu já tinha muitas atividades, já vi os monitores apresentando né? Antes. Então... Eu prestava atenção neles apresentando, eventualmente dependo da atividade no meio de uma visita que eu participei é... Um monitor virou e "falou vai agora tenta aí apresentar". Aí você tenta dá, às vezes, dá aquela gaguejada né enfim. Mas assim pessoalmente eu nunca tive muito problema pra falar em público então... Esse problema pelo menos eu não passei, mas obviamente eu tive muitos ganhos na questão de elaborar uma linha de raciocínio e a minha construção assim no começo eu usava protocolo, lia o protocolo e... Eu acho que antes de vir pra EB eu vinha vindo no caminho de casa assim pensando "ah eu vou falar sobre isso" e ficava pensando como se eu estivesse explicando pra alguém, pra uma única pessoa. Eu pensava assim "ah se eu fosse explicar isso pra alguém como faria". Então ficava na minha mente que nem que martelando aquilo cerca de uma hora antes da visita pensando ah vou fazer assim assado, falo isso ai chegava aqui eu fazia, acho que eu... Não sei é difícil pensar de como se constrói né? Isso ao longo do tempo. 
Turno 54: [Entrevistador]: Você acha que você foi influenciado por algum... Monitor antigo tipo...?

Turno 55: [Mediado C]: Sim.

Turno 56: [Entrevistador]: Sabe me citar algum assim ah eu gostava do jeito que ele falava ou...

Turno 57: [Mediador V2]: Olha, eu gostava muito do... Fui influenciado muito pelo mediador V1 isso sem dúvida, agora quanto ao jeito de... De falar da apresentação em si... Ah, tinha um monitor que me chamava bastante atenção era o J, também 09, eu gostava muito da apresentação dele, achava impecável assim, ele tocava em todos os pontos, ele era muito claro e eu acho que me inspirei bastante nele assim, na questão de... Eu gostaria de ser tão claro quanto ele durante uma apresentação... Agora tinha uma coisa assim que ele não tinha muito aí eu acho que eu tinha necessidade de colocar é a questão da... Como posso dizer... Da desinibição assim, eu não gosto de uma coisa muito sisuda sabe? Uma apresentação sisuda, tipo séria então eu gosto sei lá, às vezes solto uma piada no meio... Eu gosto de provocar o riso, provocar eu acho que é mais gostoso aprender assim. E durante a apresentação eu tenho um retorno assim que eu percebo que quando um aluno ele se diverte com aquilo ele tende a prestar mais atenção, obviamente bem dosado né? Você não vai também ser um comediante (risos) lá na frente, um palhaço porque daí vira farra e ninguém leva a sério, mas eu acho que assim em certos momentos assim se você dosar um pouco de humor de, de sei lá de diversão ajuda bastante, isso eu acho que ele, por exemplo, não tinha muito, ele sabia muito bem, talvez isso, então isso foi uma coisa que eu incorporei assim, não isso eu acho que é uma coisa que tem que ter, mas eu me espelhei muito nele na questão da clareza, do jeito de apresentar, eu falei "nossa quero ser tão claro quanto ele" porque eu via que o pessoal entendia mesmo assim quando ele falava.

Turno 58: [Entrevistador]: Legal! E o conteúdo da tua fala vinha só do protocolo?

Turno 59: [Mediador V2]: Não. Não vinha só do protocolo, no... Nas primeiras é... O protocolo na verdade eu nunca li muito assim, só li cada atividade mais de três vezes foi muito, mas era uma coisa assim a primeira vez eu li o protocolo e daí sei lá na noite anterior da visita eu dava uma olhada na internet pra ver se eu achava alguma coisa, por uma questão assim, é eu notei isso acho que até hoje é muito claro surgem coisas que não estão no protocolo, sempre, na visita. Você está interagindo com 
pessoas, as pessoas pensam, elas não são (risos)... Elas fazem umas perguntas assim, que deixa você assim: "gente! Nem tinha pensado nisso." E daí sempre antes de uma atividade, por exemplo, de apresentar sei lá... Fisiologia da visão a primeira vez, a segunda vez que apresentei eu lembro deu sentar em frente do computador sei lá, não precisava ir muito longe assim, Wikipédia mesmo "ou deixa eu dar uma lida assim ver o que tem", às vezes aparece uma curiosidade alguma coisa assim que é interessante você falar e que o pessoal curtir né? Querendo ou não eles te escutam um pouco assim dá... Momento Discovery sabe? (Fala do mediador V2)

Ao mesmo tempo em que o objetivo principal aparece claramente nas falas dos mediadores $\mathrm{N} 1$ e N2, os demais objetivos não aparecem de maneira uniforme. Na fala do mediador N1, aparecem três objetivos: formar mediadores, produzir materiais e transformar o visitante. Já na fala do mediador N2, aparecem dois objetivos: formar mediadores e passar conhecimento para os visitantes. Isso pode indicar que a definição completa dos objetivos da EB ainda encontra-se em fase de negociação.

Turno 53: [Mediador N1]: [...] Eu diria o segundo objetivo da EB é... Fazer materiais, materiais didáticos. Então, se a gente não tá fazendo visita, a gente tá fazendo comissão. Então, na comissão é... Eu acho que a gente tem que trabalhar na criação de atividades e metodologias de ensinar uma coisa que já tem no currículo básico da escola, só que de maneiras diferentes, de maneiras mais práticas, mais divertidas, mais didática. Criação de atividades e materiais de atividades. E o terceiro objetivo seria... A transformação do próprio aluno que vem visitar. Ele ganhar não só uma carga de conteúdo quando vem aqui, mas também ganhar uma carga emocional. É... Fazer ele... Criar esses momentos de, de... De visita. Fazer com que eles se vislumbrem com a visita e assim, não, necessariamente, formar novos biólogos ne, a partir dessas crianças, desses adolescentes. Mas formar pessoas que tem noção disso que... Que não ignorem a biologia como uma coisa a parte, como uma coisa chata, uma coisa reservada só para os biólogos ne. E plantar um pouco de biologia neles. (Fala do mediador N1 na segunda entrevista)

Turno 14: [Mediador N2]: [...] E... Sei lá. Formar... Trocar com o público assim, sabe. Através dessas atividades ne, e bolar atividades novas, passar esse 
conhecimento. [...] Claro que é muito importante uma criança que tá na escola pública e nunca tem laboratório, nunca viu nada. Ai ela vem aqui vê um bicho vivo, um bicho no álcool. Pode pegar. É uma experiência pra vida e tudo mais. Acho que é muito importante... (Fala do mediador N2 na segunda entrevista)

Outro significado negociado pelos membros da EB é a dinâmica de trabalho envolvendo os mediadores bolsistas e voluntários. Foi acordado entre eles que o mediador só pode permanecer como bolsista por, no máximo, dois anos e que o bolsista deve trabalhar o dobro do tempo que o mediador voluntário trabalha.

Turno 57: [Entrevistador]: Você já é bolsista há quanto tempo lá?

Turno 58: [Mediador V1]: Há dois anos e meio. Inclusive a gente estabelece um regulamento interno, no máximo fica dois anos, né. E eu to... (risos)...

Turno 59: [Entrevistador]: No limiar...

Turno 60: [Mediador V1]: É. O bolsista né, eu né, basicamente eu faço, é..., mas isso é meio pela minha personalidade. A gente nunca chegou a um consenso muito grande sobre o que um bolsista faz ne. E os nossos veteranos, ne, não passaram uma definição muito clara, também. Então, eu acho assim, que algumas dessas definições do que é ser bolsista, meio que eu que inventei e passei pro resto do pessoal (risos). Porque nunca ficou muito claro pra gente ne. A gente sabia que o bolsista era o cara que trabalhava mais ne, em termos bem simples assim. Ele trabalha quatro horas a mais. Se o voluntário se compromete em fazer um período de visita, o bolsista se compromete a dois, basicamente ne. E se um voluntário tem que fazer um determinado número de manutenções de animais, que a gente faz em escala ne, num mês a gente tem uma escala, por exemplo, precisa cuidar do bicho pau, sei lá é..., dá quinze vezes por mês ne, pra cuidar do bicho pau. Se a gente tiver quinze monitores, uma vez por mês um monitor tem que ir lá cuidar do bicho pau. Isso é um acordo comum. $\underline{O}$ bolsista tem que fazer, a gente entrou em acordo, mais ou menos o dobro, em termos temporais ne, termos oficiais o bolsista tem que trabalhar o dobro do tempo. (Fala do mediador V1)

Ainda sobre negociação de significados, Wenger (1998) defende que mesmo que algo seja reificado, ele será negociado na prática até tomar uma forma agradável aos membros da 
comunidade. Como há uma rotatividade de mediadores na EB, essa negociação de algo já reificado pode acontecer cada vez que houver uma mudança na composição e, consequentemente, na identidade da EB. Isso pode ser observado nas falas a seguir dos mediadores N1 e N2 sobre a necessidade de mudanças ou criação de atividades apresentadas nas visitas. O mediador N2 evidencia, inclusive, que essas mudanças são necessárias, porque essas atividades já existiam quando eles entraram na EB e, por isso, não participaram da construção das mesmas.

Turno 90: [Entrevistador]: E pra terminar, você participa ou pretende participar da elaboração das atividades da EB?

Turno 91: [Mediador N1]: Participo bastante e... Se eu participo, então, quer dizer que eu pretendo (risos). Participo bastante. A gente tá fazendo uma fisio agora de três horas ne. A gente faz, normalmente, uma hora e meia.

Turno 92: [Entrevistador]: Uma hora e meia.

Turno 93: [Mediador N1]: Que vai ter audição que a gente não tem, por exemplo. E tô participando de uma de lixo também, de... Dessa do descarte e de repensar sobre o consumo de lixo. Lixo orgânico e inorgânico, reciclagem e... Eu pretendo sim, fazer novas atividades e eu quero encher aquele site de atividades e atividades boas, ne. Porque, às vezes, a gente sempre fica naquelas: trilha da biodiversidade, escoisos e fisiologia. Meu vamos além. Vamos colocar ecologia também. Fazer umas coisas diferentes. Falta... Faltam algumas áreas da biologia que tem carros chefes ne, na $\underline{E B}$. Então, eu acho que eu pretendo fazer isso. (Fala do mediador N1 na segunda entrevista)

Turno 36: [Mediador N2]: [...] Mas, acho que a atividade que eu mais gosto, que eu acho mais redondinha, assim, a mais legal é a dos escoisos né. Do de genética. Inclusive agora mudou de nome viu? No nosso site tá chamando laboratório da genética.

Turno 37: [Entrevistador]: Ah, eu vi.

Turno 38: [Mediador N2]: É então. É porque a gente tava achando esse nome meio estranho (risos). [...]

Turno 40: [Mediador N2]: [...] Mas ai, tem aquela coisa. Tem uma angustia assim. $\underline{\text { Porque eu acho que a EB tá muito tempo sem atividades novas, entendeu? } \underline{E} \text { ai você }}$ 
acaba ficando naquela, naquela angustia mesmo de fazer sempre essa mesma coisa e ficar muito atrelado aquilo que já tá pronto há muito tempo. Você não fez parte da construção daquela atividade. Eu cheguei aqui, as três atividades que mais saem que é fisiologia, os escoisos e biodiversidade, desde que eu entrei já existe. Já existe há muito tempo, então, eu acho que, às vezes, você não tá pegando com as duas mãos assim. Agora a gente tá editando ne, a atividade de fisiologia, o mediador N1 que tá encabeçando isso. Então, tem uma porção de coisas novas lá, eu acho que isso vai ser bom pra dar uma... Uma refrescada na coisa. [...] (Fala do mediador N2 na segunda entrevista)

De acordo com Wenger (1998), a negociação de significados cria entre os participantes uma relação de responsabilidade mútua que envolve o desenvolvimento de percepções para fazer julgamentos sobre a prática desenvolvida, permitindo aos participantes negociar a adequação do que eles fazem.

Como elucidado na seção sobre engajamento mútuo, houve uma mudança de mediadores bolsistas durante a coleta de dados dessa pesquisa e os bolsistas que assumiram se organizaram em departamentos divididos em relações internas, relações externas, parte financeira, parte de compras, divulgação, coordenadoria pedagógica e manutenção. Nota-se que esses mediadores negociaram a adequação do que eles fazem.

Turno 59: [Entrevistador]: Foi você quem quis ou te colocaram nessa função?

Turno 60: [Mediador N2]: Então, foi mais ou menos assim, a gente sentou todo mundo e falou "acho que são essas as principais funções dos bolsistas". A gente ficou discutindo quais eram as funções. E ai, foi meio por interesse. Quem tem interesse de fazer isso, quem tem interesse de fazer aquilo. É... E assim eu gosto muito dessa parte e tinha interesse em outras áreas também, mas foi assim por combinado mesmo. (Fala do mediador N2 na segunda entrevista)

Turno 28: [Entrevistador]: Legal. E... Você falou pra mim também que agora a turma de vocês organizou os bolsistas em departamentos.

Turno 29: [Mediador N1]: Sim.

Turno 30: [Entrevistador]: E quais são esses departamentos mesmo? 
Turno 31: [Mediador N1]: Bom, vamos lá. Tem esse, relações internas, que eu estou.

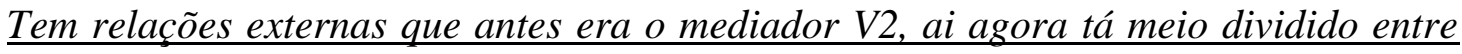
eu, o mediador C e o mediador N2. A gente tem a parte financeira, que é o mediador $M$, que é bichete. A gente tem a parte de compras, que é o mediador T. Ele organiza $O$ que deve ser comprado, a gente se reporta a ele o que precisa comprar. Tem a parte de divulgação, que é a o mediador To, que também é bichete. E tem... Esqueci de algum.

Turno 32: [Entrevistador]: Tem o mediador $C$.

Turno 33: [Mediador N1]: E tem o mediador C, que é uma coordenação pedagógica. Então, nesse caso, por exemplo, nesse passo a passo de criação de atividades eu acho que caberia a ele fazer ne. E ele avalia também as visitas e... Vê como pode melhorar as visitas, as atividades. E tá faltando o mediador N2. Eu não lembro o que ele faz (risos). Ai. Eu falei.

Turno 34: [Entrevistador]: Relações internas, externas, coordenador pedagógico, compra, divulgação, manutenção...

Turno 35: [Mediador N1]: Ah, manutenção, mas não é o mediador N2. Manutenção, que é o mediador $\mathrm{Tr}$, que é um bicho. O mediador $\mathrm{N} 2$ tá... Ai (risos). Ele sempre tá. (Fala do mediador N1 na segunda entrevista)

Uma prática observada na EB é que enquanto alguns significados são negociados pelos seus respectivos membros, como visto anteriormente, outros significados parecem ser pensados por apenas alguns mediadores e aceito pelos demais, principalmente, quando a ideia surge de um mediador que está muito tempo na EB. Alguns mediadores, inclusive, reportam que está tendência acontece com certa frequência na $\mathrm{EB}$, uma vez que os mediadores novatos aceitam sem reivindicar o que é dito pelos mediadores veteranos.

Turno 46: [Mediador N2]: [...] E, eu acho que por isso também é muito importante que os monitores estejam super articulados, porque, uma das discussões que a gente tava tendo no começo da semana com o mediador V2 e com alguns bolsistas enfim, alguns monitores, é essa coisa assim: o monitor vai ficando mais velho, ele vai ficando mais por dentro de tudo, ele já sabe tudo como ele resolve e... Ninguém mais começa a contestar isso, entendeu? Porque ele é... Afinal de contas ele tá lá há cinco anos, sei lá há quatro, cinco anos, então ele deve tá falando coisa que é real, mas no 
final das contas é... Quem faz esse projeto são os... O pessoal que acabou de entrar, o pessoal do segundo ano, do terceiro, enfim, mas começa a se afastar e querendo ou não a graduação te puxa a atenção pra algumas coisas e muita gente sai nessa fase ne. [...] (Fala do mediador N2 na segunda entrevista)

Turno 26: [Mediador N4]: [...] Agora, um ponto negativo. Eu não sei. Mas eu diria que, às vezes... É... sei lá. A EB tem alguns vícios em que ela... Ao mesmo tempo em que ela se mostra é... Permissiva pra tentar coisas novas em relação as atividades, ela, às vezes, não quer mudar a estrutura dela. Por exemplo, um pouco antes de eu sair tinha... Teve reuniões gerais em que a gente propôs reinventar o sistema de manutenções e tal. E ai o pessoal não quis mudar. Simplesmente porque ah, não vai dar certo. Tipo, não quis nem tentar. E ai... Eu senti isso pô, mas se vocês querem experimentar nas atividades, não querem experimentar na estrutura do negócio né? Então, tem uma certa rigidez assim. E isso em parte é porque, acho que o pessoal cria as hierarquias baseada em que é bolsista e quem não é. Tipo, as pessoas que são bolsistas são mais ouvidas na reunião. Eu percebi isso assim. Por mais que esse não tenha sido o intuito, inclusive os bolsistas vivem falando que isso não procede, o pessoal não tá nem aí. Eles criam essa hierarquização na cabeça deles. (Fala do mediador N4 na segunda entrevista)

Turno 60: [Mediador V1]: É. O bolsista né, eu né, basicamente eu faço, é..., mas isso é meio pela minha personalidade. A gente nunca chegou a um consenso muito grande o que um bolsista faz né. E os nossos veteranos, né, não passaram uma definição muito clara, também. Então, eu acho assim, que algumas dessas definições do que é ser bolsista, meio que eu que inventei e passei pro resto do pessoal (risos). [...] (Fala do mediador V1).

Essa diferença existente na EB entre o mediador bolsista e o voluntário já tinha sido observado na sessão sobre engajamento mútuo. Sobre isso, somente os membros que tiverem um engajamento efetivo, que se sentirem parte da comunidade de prática Estação Biologia conseguirão concordar ou não com o que é proposto e sugerir soluções para tais situações, gerando um ambiente rico para negociação de significados. Mas para isso, é necessário que, na EB, seja criado um espaço para identificação de tensões e conflitos para que eles sejam 
resolvidos (ou não), mas para que haja, sobretudo, oportunidade de todos os membros contribuírem de forma democrática, sem que a hierarquia bolsista-voluntário, influa nas decisões tomadas pela e para a EB. Os mediadores da EB precisam, por exemplo, identificar se a existência da bolsa é um fator motivador ou desmotivador e gerar soluções para que a bolsa não seja a única e exclusiva forma de garantir um maior envolvimento dos mediadores.

Mesmo que haja essa diferença na EB, é possível encontrar objetivo em comum, responsabilidade mútua, significados negociados ou em negociação, itens esses que resultam em um empreendimento conjunto.

\subsection{Repertório compartilhado}

Símbolos, palavras, gestos, artefatos, documentos, rotinas, ações, conceitos e normas que a comunidade tenha produzido ou adotado ao longo de sua existência e que se tornaram parte de sua prática são características que compõem o elemento repertório compartilhado (WENGER, 1998).

Foi possível detectar vários desses componentes na EB. Faz parte da rotina desta COP, por exemplo, planejar e executar as visitas, fazer as manutenções dos materiais vivos e não vivos, fazer reuniões pós-visitas como método avaliativo das mesmas, apresentar a EB todo ano aos calouros do curso de Ciências Biológicas do IBUSP, fornecer treinamento para os mediadores novatos. Essas ações desenvolvidas rotineiramente estão descritas no "Manual de Sobrevivência da Estação Biologia”, documento escrito pelos próprios mediadores, demonstrando que essas ações já estão reificadas, pertencendo ao repertório compartilhado da EB. A elaboração deste documento careceu da negociação de significados, pois somente o que é negociado pela comunidade molda a prática (WENGER, 1998). Só assim os elementos do repertório compartilhado em uma COP vão ser coerentes com a sua prática.

Além de rotinas, algumas normas estabelecidas e que já fazem parte do repertório compartilhado da EB apareceram nas falas dos mediadores. Nesta fala do mediador V1, ele comenta que a permanência de um monitor como bolsista é de no máximo dois anos, norma estabelecida pelos próprios mediadores.

Turno 57: [Entrevistador]: Você já é bolsista há quanto tempo lá?

Turno 58: [Mediador V1]: Há dois anos e meio. Inclusive a gente estabelece um regulamento interno, no máximo fica dois anos ne. E eu to... (risos)... 
Turno 59: [Entrevistador]: No limiar... (Fala do mediador V1)

O fato de o mediador bolsista trabalhar o dobro do tempo que o mediador voluntário trabalha é outra norma que faz parte do repertório compartilhado da EB.

Turno 60: [Mediador V1]: [...] A gente sabia que o bolsista era o cara que trabalhava mais né, em termos bem simples assim. Ele trabalha quatro horas a mais. Se o voluntário se compromete em fazer um período de visita, o bolsista se compromete a dois, basicamente né. E se um voluntário tem que fazer um determinado número de manutenções de animais, que a gente faz em escala né, num mês a gente tem uma escala, por exemplo, precisa cuidar do bicho pau, sei lá é..., dá quinze vezes por mês né, pra cuidar do bicho pau. Se a gente tiver quinze monitores, uma vez por mês um monitor tem que ir lá cuidar do bicho pau. Isso é um acordo comum. O bolsista tem que fazer, a gente entrou em acordo, mais ou menos o dobro, em termos temporais né, termos oficiais o bolsista tem que trabalhar o dobro do tempo. (Fala do mediador V1)

Outra norma estabelecida como repertório compartilhado da EB é que os mediadores que entraram recentemente irão formar os mediadores do próximo ano.

Turno 51: [Mediador V2]: Tá. Ó, quanto ao treinamento é uma coisa muito assim, a gente tem preocupação que faça parte do treinamento que você treine outros monitores, então o ano que acabou de entrar, por exemplo, 2012 obrigatoriamente eles vão treinar 2013, a gente deixa o treinamento na mão deles. Obviamente a gente ajuda, com qualquer dúvida, qualquer problema a gente esta lá pra dar opinião, sugestão, fala como foi no passado, como pode ser, mas a gente gosta de deixar na mão deles assim... (Fala mediador V2)

Gestos também podem fazer parte do repertório compartilhado de uma COP e, no caso da EB, um gesto feito por vários mediadores de estalar os dedos com as duas mãos levantadas acima da cabeça para solicitar silêncio aos visitantes (Figura 06) pôde ser observado em várias visitas, evidenciando que esse gesto faz parte do repertório compartilhado da EB. 


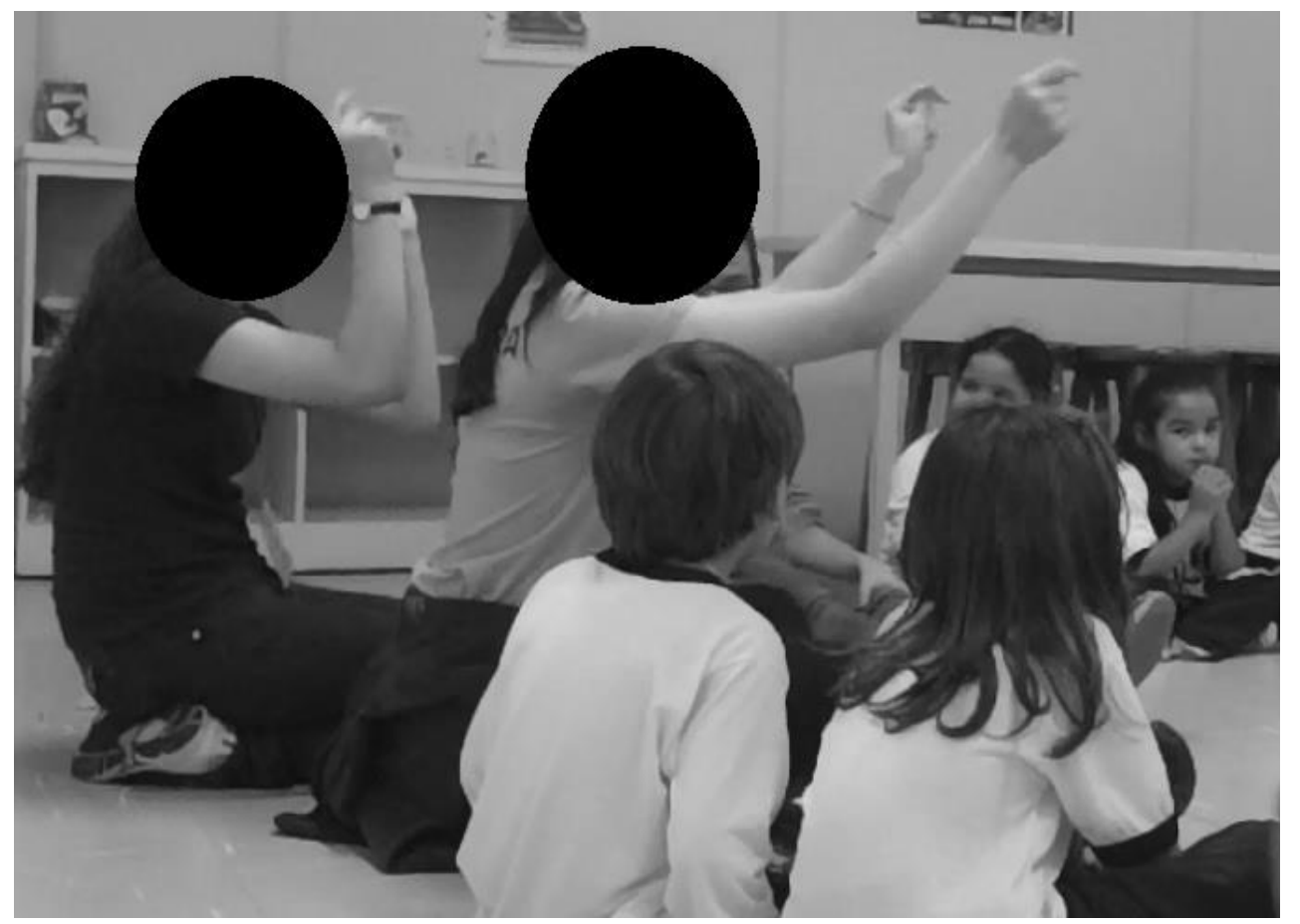

Figura 06. Gestos usados pelos mediadores como evidência do repertório compartilhado pela EB.

Tendo em vista tudo o que foi apresentado nesse capítulo, pode-se afirmar que a EB pode ser considerada uma comunidade de prática. Para ficar mais claro, a tabela abaixo faz um resumo sobre as evidências encontradas na EB que justificam essa afirmação.

Tabela 03. Evidências encontradas nos dados coletados que justificam a EB ser considerada uma COP.

\begin{tabular}{|c|c|c|}
\hline $\begin{array}{c}\text { Elementos de uma } \\
\text { COP }\end{array}$ & Evidências Encontradas & Exemplos \\
\hline Domínio & $\begin{array}{l}\text { Os membros da EB visam aprender } \\
\text { aspectos teóricos e práticos de didática, } \\
\text { como comunicar-se de maneira clara e } \\
\text { fazer a transposição de conhecimento } \\
\text { para o público visitante. }\end{array}$ & $\begin{array}{l}\text { Turno 20: [Mediador N1]: "[...] Primeiramente pra } \\
\text { aprender a didática pra passar o conhecimento. Eu vejo } \\
\text { pessoas que tem um conhecimento muito grande e não } \\
\text { sabem repassar isso". (Fala mediador N1 na primeira } \\
\text { entrevista). } \\
\text { Turno 26: [Mediador N3]: "Isso é porque eu tenho muita } \\
\text { vergonha de falar em público. E eu achei que talvez fosse } \\
\text { uma forma de eu começar a me soltar um pouco mais. Pra } \\
\text { conseguir falar na frente das pessoas, explicar". (Fala } \\
\text { mediador N3 na primeira entrevista). }\end{array}$ \\
\hline Comunidade & $\begin{array}{l}\text { Os membros da EB estabelecem um } \\
\text { vínculo através do engajamento em torno } \\
\text { da necessidade partilhada de se aprender } \\
\text { aspectos teóricos e práticos de didática. }\end{array}$ & $\begin{array}{l}\text { Membros da EB envolvidos em atividades conjuntas, } \\
\text { como a atuação em visitas, manutenção dos materiais } \\
\text { vivos e não vivos da EB, criação de novas atividades para } \\
\text { visita, entre outras. }\end{array}$ \\
\hline
\end{tabular}




\begin{tabular}{|c|c|c|}
\hline Prática & $\begin{array}{l}\text { Membros da EB envolvidos em } \\
\text { atividades conjuntas, gerando um } \\
\text { repertório compartilhado. }\end{array}$ & $\begin{array}{l}\text { Manual de Sobrevivência: documento gerado pelos } \\
\text { mediadores onde são encontradas diretrizes para atuação } \\
\text { dos mediadores: conceitos, rotinas e ações pertencentes à } \\
\text { EB. }\end{array}$ \\
\hline Qual é o objetivo? & $\begin{array}{l}\text { O objetivo da EB é formar mediadores e } \\
\text { disponibilizar para a sociedade uma } \\
\text { forma prática e lúdica de se aprender } \\
\text { biologia. }\end{array}$ & $\begin{array}{l}\text { Turno 14: [Mediador N2]: “[...] No final das contas não } \\
\text { dá pra fugir muito dos objetivos da EB [...] Criar, como } \\
\text { fala? Formar monitores, ne. Afinal de contas, a gente } \\
\text { muda muito assim. Eu vejo que eu mudei muito desde que } \\
\text { eu entrei até agora”. (Fala do mediador N2 na segunda } \\
\text { entrevista). } \\
\text { Turno 68: [Mediador N4]: "Educar de forma lúdica } \\
\text { (risos) a biologia, assim. Ensinar uma forma diferente do } \\
\text { que as crianças aprenderiam em sala de aula”. (Fala do } \\
\text { mediador N4 na primeira entrevista) }\end{array}$ \\
\hline Quem participa? & $\begin{array}{l}\text { Participantes se auto selecionam, não há } \\
\text { nenhuma intervenção da instituição para } \\
\text { escolha dos membros da EB. Não } \\
\text { possuem contrato. Os estudantes de } \\
\text { Biologia escolhem participar da EB e } \\
\text { permanecem lá até quando for } \\
\text { necessário. }\end{array}$ & $\begin{array}{l}\text { No início de cada ano letivo, os alunos veteranos do curso } \\
\text { de Ciências Biológicas da USP fazem uma semana de boas } \\
\text { findas aos calouros. Isso inclui apresentar todos os grupos } \\
\text { com atividades extracurriculares, como o Centro } \\
\text { Acadêmico, a Atlética, o grupo que organiza a Semana } \\
\text { Temática de Biologia, a Estação Biologia, entre outros. Os } \\
\text { alunos interessados nas atividades da EB passam por uma } \\
\text { semana de treinamento, ministrado pelos mediadores } \\
\text { veteranos, e se decidirem continuar, começam a atuar nas } \\
\text { visitas. (Informação retirada do Manual de Sobrevivência e } \\
\text { de observações diretas de campo). }\end{array}$ \\
\hline $\begin{array}{l}\text { O que têm em } \\
\text { comum? }\end{array}$ & $\begin{array}{l}\text { Através de observações diretas de campo } \\
\text { e de falas como as dos mediadores } \mathrm{N} 2 \mathrm{e} \\
\mathrm{N} 1 \text { mostradas na coluna ao lado, foi } \\
\text { possível identificar a paixão e o } \\
\text { compromisso que os mediadores têm } \\
\text { com a biologia e com a EB. Além disso, } \\
\text { eles se identificam com os } \\
\text { conhecimentos gerados pela EB e } \\
\text { acreditam que isso possa auxiliá-los de } \\
\text { alguma forma na formação profissional. }\end{array}$ & $\begin{array}{l}\text { Turno 6: [Mediador N1]: "Primeiramente, porque eu } \\
\text { adoro a área da zoologia e também tive professores muito } \\
\text { especiais, assim, de biologia. Tanto que eu queria dar aula } \\
\text { também. Me inspirou muito ter professores assim. Por isso } \\
\text { que eu estou na EB também para aprender didática". } \\
\text { (Fala do mediador N1 na primeira entrevista). } \\
\text { Turno 44: [Mediador N2]: "[...] Tanto fazer uma coisa } \\
\text { para a comunidade, porque as escolas vem e todos os } \\
\text { visitantes vão levar alguma coisa daqui ou pelo menos éo } \\
\text { que a gente espera, né? Então uma coisa de divulgar } \\
\text { mesmo, mais cultura assim, mais informação. Mas eu acho } \\
\text { que é um aprendizado pra todo mundo que participa. Pra } \\
\text { todos os monitores. Eu diria que talvez mais do que trazer } \\
\text { uma coisa pra sociedade, eu vejo como se fosse um } \\
\text { laboratório, fosse um aprendizado pro pessoal que tá aqui. } \\
\text { Porque tudo isso que a gente tá fazendo é ganhar } \\
\text { experiência. E depois quando sair daqui, isso vamos levar }\end{array}$ \\
\hline
\end{tabular}


com a gente e lógico que tem um retorno pra sociedade. É então eu acho que é meio mútuo (risos)". (Fala do mediador N2 na primeira entrevista).

A EB, antiga Comissão de Visitas (CV), surgiu em 1986 com a função de receber grupos escolares de $1^{\circ}$ e $2^{\circ}$ graus das redes estadual e municipal de ensino, a pedido da

Quanto tempo dura? A EB existe desde 1986 e durará enquanto houver interesse em manter o grupo. extinta Coordenadoria de Divulgação de Atividades Culturais (CODAC). (Informação retirada do Manual de Sobrevivência).

Não há indícios que afirmem que a EB tem uma data limite para deixar de existir.

Turno 32: "[...] Ele que é o elemento central (referindo-se a outro mediador). Administrativamente ele é central. Se pensar em termos de espírito do grupo, pode ser que eu ainda esteja nessa posição, mas administrativamente é A EB possui níveis de participação que ele." (Fala mediador V1).

variam do centro à periferia.

Observações diretas de campo também permitiram verificar que existem mediadores da EB que não dominam a prática ou que tem um nível de envolvimento baixo e por isso são periféricos.

Durante a visita é comum presenciar mediadores novatos prestando atenção na apresentação do veterano ou perguntando sobre alguma questão, ou ainda, algum veterano corrigindo alguma informação errada que o novato falou durante a apresentação. Além disso, durante as reuniões pós-visita, é feita uma avaliação pelos próprios mediadores e contribuições são levantadas, sugerindo como um determinado mediador deveria ter agido ou como deveria ter falado.

Turno 42: [Mediador N2]: "Então, foi escolha minha, mas foi sugestão também. Assim: "Ah, sua primeira visita, é mais legal você ficar observando". Tanto que eu fiquei, quando eu contei o tempo lá fora, eu fiquei ouvindo o que os outros monitores estavam falando pros grupos. Ai eu já tenho uma ideia do que eles costumam falar e como é a dinâmica". (Fala do mediador N1 na primeira entrevista).

A EB é formada pelas identidades de cada mediador, as quais são unidas pelo engajamento para formar uma identidade coletiva.
Turno 71: [Mediador N1]: [...] "Ele tem o comprometimento devido, adequado de todo monitor, mas eu acho que ele não queria muitas responsabilidades... Perante a EB. É... Eu acho que ele teria... Queria fazer outras coisas também, né? Não ficar tão, tão atolado em 
cargas, né?" (Fala do mediador N1 na segunda entrevista).

Mediadores possuem a ideia de

pertencimento à $\mathrm{EB}$, o que pode auxiliar na movimentação centrípeta nos níveis de participação.
Turno 6: [Mediador N2]: "[...] porque eu fui me

envolvendo muito, assim, e eu senti que eu estava fazendo parte daquilo e que eu estava gostando do resultado. Eu gosto de ver a EB andar. Eu gosto de ver as coisas acontecendo [...]" (Fala do mediador N2 na segunda entrevista).

Turno 14: [Mediador N2]: "[...] Formar monitores, né? Afinal de contas, a gente muda muito assim. Eu vejo que eu mudei muito desde que eu entrei até agora”. (Fala do mediador N2 na segunda entrevista).

Turno 53: [Mediador N1]: [...] E o terceiro objetivo

\section{Empreendimento}

\section{Conjunto} A EB possui pelo menos dois objetivos em comum identificados pelos seus participantes: formar mediadores e promover visitas para divulgar conceitos biológicos

Existem significados negociados como objetivo principal da EB e o tempo de vigência de cada bolsista e significados em negociação como os demais objetivos da EB.

seria... A transformação do próprio aluno que vem visitar. Ele ganhar não só uma carga de conteúdo quando vem aqui, mas também ganhar uma carga emocional. É... Fazer ele... Criar esses momentos de, de... De visita. Fazer com que eles se vislumbrem com a visita e assim, não, necessariamente, formar novos biólogos né? A partir dessas crianças, desses adolescentes. Mas formar pessoas que tem noção disso que... Que não ignorem a biologia como uma coisa a parte, como uma coisa chata, uma coisa reservada só para os biólogos né? E plantar um pouco de biologia neles. (Fala do mediador N1 na segunda entrevista).

Turno 58: [Mediador V1]: Inclusive a gente estabelece um regulamento interno, no máximo fica dois anos, né? (Fala do mediador V1 se referindo ao tempo máximo de permanência de um mediador como bolsista.).

Na segunda entrevista, feita com os mediadores N1 e N2, aparecem falas em que o primeiro mediador aponta três objetivos: formar mediadores, produzir materiais e transformar o visitante; enquanto o segundo aponta dois objetivos: formar mediadores e passar conhecimento para os visitantes, indicando que a definição completa dos objetivos da EB ainda encontra-se em fase de negociação.

Turno 60: [Mediador N2]: Então, foi mais ou menos

Os mediadores da EB possuem assim, a gente sentou todo mundo e falou "acho que são responsabilidade mútua sobre a prática realizada, promovendo percepções e adequações a essa prática. essas as principais funções dos bolsistas". A gente ficou discutindo quais eram as funções. $E$ ai, foi meio por interesse. Quem tem interesse de fazer isso, quem tem interesse de fazer aquilo. É... E assim eu gosto muito dessa 


\begin{tabular}{|c|c|c|}
\hline & & $\begin{array}{l}\text { parte e tinha interesse em outras áreas também, mas foi } \\
\text { assim por combinado mesmo. (Fala do mediador N2 na } \\
\text { segunda entrevista) }\end{array}$ \\
\hline $\begin{array}{c}\text { Repertório } \\
\text { Compartilhado }\end{array}$ & $\begin{array}{l}\text { Foram observadas rotinas, ações, } \\
\text { normas, documentos e gestos que fazem } \\
\text { parte do repertório compartilhado da EB. }\end{array}$ & $\begin{array}{l}\text { Manual de Sobrevivência é um documento gerado pelos } \\
\text { mediadores que faz parte do repertório compartilhado da } \\
\text { EB. } \\
\text { Gesto feito por vários mediadores de estalar os dedos com } \\
\text { as duas mãos levantadas acima da cabeça para solicitar } \\
\text { silêncio aos visitantes. }\end{array}$ \\
\hline
\end{tabular}




\section{Capítulo 5. O Engajamento Mútuo como Elemento Formativo de Mediadores}

No capítulo anterior, foi considerado que a EB, além de ser um projeto de extensão universitária com caráter de Educação Não Formal, possui os elementos necessários para ser considerada uma comunidade de prática, questão pertencente ao primeiro objetivo dessa pesquisa. Respondido o primeiro quesito, neste quinto capítulo será abordada a segunda parte desse trabalho que compreende a análise de como o elemento engajamento mútuo pode contribuir para a formação inicial de mediadores, não só da EB, como de outros espaços de Educação Não Formal ou Formal.

Este trabalho dá enfoque ao engajamento mútuo como elemento formativo, pois esse foi identificado como central, visto que promove o empreendimento conjunto e o repertório compartilhado. Sem o engajamento mútuo não seria possível desenvolver um empreendimento em conjunto e muito menos compartilhar um repertório. Contudo, sabe-se que em uma COP os elementos engajamento mútuo, empreendimento conjunto e repertório compartilhado devem ser analisados em conjunto, já que um é complementar ao outro, se influenciam e se determinam mutuamente. O engajamento mútuo gera a prática e o compromisso existente entre os membros da comunidade, permitindo que esses realizem um empreendimento conjunto. O histórico do engajamento mútuo resulta em um repertório compartilhado que é a reificação do empreendimento conjunto da comunidade. É possível afirmar que o engajamento mútuo, ao mesmo tempo em que se constitui como gerador da prática da comunidade é, em contra partida, abastecido e influenciado por essa prática.

Assim, justifica-se o foco de análise no engajamento mútuo, pois - além de este ser interpretado aqui como central frente aos outros dois - pautando-se nesse elemento, é possível destacar o indivíduo pertencente à comunidade para interpretar suas falas e ações e, a partir desse indivíduo, visualizar a comunidade como um todo. Torna-se importante relembrar, portanto, que o engajamento mútuo é resultado da movimentação centrípeta pelos níveis de participação, da interação entre os membros, da ideia de pertencimento e da identidade individual e coletiva de uma COP. A partir disso, acredita-se que processos formativos de mediadores que se proponham a desenvolver esses itens, possam promover maior engajamento dos membros participantes.

Utilizando o estudo de caso feito na EB, podem-se elencar situações que acontecem nesse espaço que ajudam a aumentar o engajamento mútuo e que seriam passíveis de serem utilizadas em outras instituições. Uma delas é a flexibilidade frente às funções desempenhadas 
pelos mediadores. Na Estação Biologia, existem funções bem definidas, como fazer as manutenções dos materiais vivos e não vivos, criar novas atividades, agendar as visitas, se $\operatorname{plotar}^{18}$ em determinadas apresentações na visita, entre outras. Apesar das funções serem bem definidas, qualquer mediador pode desempenhá-las, garantindo que todos possam experimentar diferentes papéis dentro da EB. Isso ajuda o mediador a identificar suas competências e habilidades, fazendo-o compreender melhor sua identidade e como relacionála à identidade da comunidade. Isso significa que ele consegue enxergar onde conseguirá contribuir de modo mais eficaz naquela comunidade. Além disso, a possibilidade de experimentar todos os papéis da EB promove uma maior compreensão do que é esse programa, quais regras e conceitos são envolvidos, como é a dinâmica de funcionamento, como ser um membro participante, ou seja, conhecimentos necessários para que um membro se torne mais engajado e, consequentemente, central. $\mathrm{O}$ aumento da compreensão sobre o que é a comunidade EB e como esta funciona, também desenvolve o sentimento de pertencimento, pois assim os mediadores tornam-se familiarizados com o que acontece ali e sentem-se parte dessa comunidade.

Outra situação é o ambiente rico para troca de experiências, tanto relacionadas à como proceder em uma visita, como aos conceitos biológicos envolvidos. Isso é possível porque existe interação entre os membros, seja uma interação entre mediadores veteranos e novatos, ou porque dentro da EB existem graduandos de ciências biológicas cursando disciplinas de semestres variados, ou ainda porque eles recebem ajuda externa ${ }^{19}$ para elaborar atividades. Essa troca de experiências aumenta a compreensão dos conceitos necessários na $\mathrm{EB}$, o que promove um maior engajamento.

$\mathrm{Na}$ realidade, alguns aspectos nesse ambiente de trocas da EB precisam ser melhorados para potencializá-lo. Como sugestões, poderiam ser feitos encontros permanentes, como o Papo Pedagógico ${ }^{20}$, em que fossem discutidos, com embasamento teórico, temas de licenciatura e de biologia que ajudassem no desenvolvimento da prática da EB. Além disso, esses mesmos encontros poderiam ser utilizados para detectar conflitos e tensões da COP, para que os significados fossem negociados por todos os mediadores, independentes de serem bolsistas ou voluntários, veteranos ou novatos. Outro quesito é melhorar as relações externas

\footnotetext{
${ }^{18}$ Esse termo plotar é utilizado pelos mediadores da EB para definir o que cada mediador irá apresentar durante a visita.

${ }^{19}$ Quando a EB cria uma atividade nova, os mediadores pesquisam sobre o tema e pedem ajuda a professores especialistas da área a qual a atividade pertença. Por exemplo, a atividade de genética, chamada anteriormente de Escoiso, foi formulada com ajuda de professores da área de genética do IBUSP.

${ }^{20}$ Papo pedagógico foram encontros promovidos pelo mediador V1 para discutir temas da licenciatura, como Educação Não Formal, transposição didática, entre outros.
} 
da EB. Isso pode ser feito por meio dos brokers, termo utilizado por Wenger (1998) para designar aquela pessoa que participa de mais de uma COP e que tem facilidade em transitar por elas, aliando as experiências vivenciadas em cada uma e fazendo o intercâmbio entre elas. Mônaco (2013), afirma que a atuação desses membros "amplia a oportunidade de aprendizado a todos os implicados na prática". Todas essas sugestões mencionadas podem aumentar o engajamento dos mediadores, ocasionando maior compreensão do que é feito na EB.

A flexibilidade dos papéis exercidos e o ambiente rico para troca de experiências são algumas situações presentes na EB que promovem o aumento do engajamento mútuo dos seus mediadores. Como consequência, esses membros desenvolvem conhecimentos que poderão ser utilizados dentro e fora da comunidade. Se isso for generalizado para outros espaços de Educação Não Formal, o aumento do engajamento mútuo associado a discussões teóricas podem auxiliar esses profissionais na apropriação de saberes necessários para mediação defendidos por Queiróz et al. (2002) e por Barros (2002), por exemplo.

Além disso, existem pesquisas, como os de Mello et al. (2013), Song et al. (2012), que analisam o engajamento dentro de ambientes empresariais e defendem que funcionários bem engajados têm um efeito positivo para a empresa, pois possuem maior nível de criatividade, de produtividade e mais vontade de ir além do simples cumprimento de tarefas. Apesar de o conceito de engajamento utilizado por esses autores ser desvinculado da teoria de comunidades de prática, esses benefícios também podem ser enxergados em uma COP. Sendo assim, mediadores bem engajados podem ser mais criativos, produtivos e dispensar mais energia para a prática exercida naquela instituição. Conseguem criar um ambiente rico para negociação de significados, propondo sugestões para resolver conflitos e tensões existentes na comunidade. Tornam-se familiarizados, por exemplo, com as ações educativas das quais fazem parte e conseguem comunicar com elementos próprios aquilo que pode ter sido elaborado somente pelo curador ou pelo coordenador do setor educativo. Também, pode-se perceber que mediadores bem engajados tendem a ser membros mais duradouros, minimizando o problema elucidado por Barros (2002) relacionado ao vínculo transitório de mediadores de espaços de Educação Não Formal. Mediadores bem engajados proporcionam uma continuidade importante para a instituição da qual fazem parte.

O engajamento mútuo é necessário para que a aprendizagem social defendida por Lave e Wenger (1991) aconteça. Os mediadores que se engajam na prática da EB, por exemplo, conseguem aprender tanto conceitos biológicos, quanto conceitos voltados à didática e ao 
trabalho em equipe. Esses conhecimentos podem ser usados tanto dentro da comunidade da $\mathrm{EB}$, como em outras comunidades que os mediadores participem ou venham a participar.

Com essa perspectiva, a Estação Biologia ultrapassa os limites de um projeto de extensão universitária com caráter de Educação Não Formal que visa formar mediadores para atuar dentro dela e passa a ser um espaço que auxilia na formação profissional desses mediadores que, antes disso, são graduandos de biologia.

Nas entrevistas realizadas com os mediadores, é possível detectar que eles próprios identificam a EB como um local que auxilia em sua formação profissional, independentemente de sua escolha posterior pela área do bacharelado ou da licenciatura.

Turno 51: [Entrevistador]: E você acredita... Você já falou algumas coisas disso, mas você acredita que a Estação Biologia vai te ajudar na sua formação profissional?

Turno 52: [Mediador N1]: Uhum. Bastante.

Turno 53: [Entrevistador]: Em que?

Turno 54: [Mediador N1]: Pra dar aula. É... Se eu for escrever algum tipo de livro didático, também, pra eu poder passar a linguagem para as crianças, também. Crianças e outros tipos de alunos. Hum... Na área de pesquisa... Ah, eu não sei! Eu tô aprendendo bastante quando eu pesquiso sobre abelhas, eu tô aprendendo bastante sobre isso. Acho que é uma carga a mais, fora das aulas ne. Basicamente é isso.

Turno 55: [Entrevistador]: Na área, você falou pra dar aula, no caso, seria o que assim pra dar aula? O que você acha que ajudaria?

Turno 56: [Mediador N1]: Adaptar a linguagem. A linguagem e os métodos de como passar o conhecimento. Entendeu? (Fala do mediador N1 na primeira entrevista).

Projetos de extensão universitária como a EB são importantes para complementar a formação inicial dos alunos de Ensino Superior. Inclusive, o Plano Nacional de Educação de 2014, estabelece como estratégia 12.7 “assegurar, no mínimo, $10 \%$ (dez por cento) do total de créditos curriculares exigidos para a graduação em programas e projetos de extensão universitária, orientando sua ação, prioritariamente, para áreas de grande pertinência social”; (PNE, Lei N¹3.005, de 25 de junho de 2014). Essa estratégia do PNE só confirma a necessidade de as instituições de Ensino Superior estimularem e investirem em projetos de extensão universitária. Primeiro, porque se trata de um componente do tripé das universidades públicas (ensino - pesquisa - extensão). Segundo, porque são espaços que podem promover 
conhecimentos que serão utilizados na vida profissional dos graduandos que deles fazem parte.

Tendo isso em vista, pensar em um processo de formação que desenvolva os itens do engajamento mútuo com os mediadores desses espaços ajudaria tanto a instituição onde esses mediadores atuam, como na atuação em comunidades que viessem participar futuramente. 


\section{CONSIDERAÇÕES FINAIS}

Foram encontradas várias evidências que confirmam que a EB pode ser considerada uma comunidade de prática. A primeira delas é a EB possuir um domínio, uma comunidade e uma prática. Como domínio existe uma necessidade, compartilhada pelos mediadores da EB, de aprender aspectos práticos de didática, como comunicar-se de maneira clara e fazer a transposição de conhecimento para o público visitante. Em torno dessa necessidade é formada uma comunidade, na qual os membros da EB se engajam em atividades conjuntas, como a atuação em visitas, manutenção dos materiais vivos e não vivos da $\mathrm{EB}$, criação de novas atividades para visita, entre outras, gerando uma prática que culmina no desenvolvimento de um repertório compartilhado entre os membros da EB, como o Manual de Sobrevivência.

A segunda evidência é a EB ter por objetivo o desenvolvimento das competências dos participantes, a geração e o compartilhamento de conhecimentos. Os participantes se auto selecionam, não há nenhuma intervenção da instituição para escolha dos membros da EB. Os estudantes de Biologia escolhem participar da EB e permanecem lá até quando for necessário. Mantêm-se unidos pela paixão à biologia e ao compromisso existente por serem um grupo de extensão universitária e se identificam com os conhecimentos gerados na EB. E sua duração perdura desde 1986 até enquanto houver interesse em manter o grupo. Todas essas características estão presentes em uma COP.

A terceira evidência é a identificação, nas falas dos mediadores da $\mathrm{EB}$, dos elementos que caracterizam uma COP:

- engajamento mútuo: níveis de participação, da ideia de pertencimento ao grupo, das interações entre os membros e da identidade que caracterizam o engajamento mútuo;

- empreendimento conjunto: o objetivo em comum do grupo, responsabilidade mútua, significados negociados ou em negociação pelos membros da EB;

- repertório compartilhado: símbolos, palavras, gestos, artefatos, documentos, rotinas, ações, conceitos e normas que a comunidade tenha produzido ou adotado ao longo de sua existência e que se tornaram parte de sua prática.

Além do apontamento e da justificativa em relação aos elementos que tornaram possível considerar a Estação Biologia como uma COP, foram encontrados indícios de que o aumento do nível de engajamento está envolvido com a transformação de um mediador periférico em um mediador central, e consequentemente, com a sua formação. Foi percebido que esse aumento de engajamento promove diretamente um aumento de domínio da prática e 
de conhecimentos desenvolvidos na EB, principalmente devido às possibilidades de flexibilização de funções e do estabelecimento de negociações internas.

Considera-se que este trabalho avança na compreensão da estruturação de comunidades de práticas em ambientes de Educação Não Formal e abre caminho para um maior entendimento de como os elementos centrais de uma COP podem contribuir para o processo formativo de educadores atuantes em diferentes espaços. Estudos posteriores são necessários para entender, por exemplo, como o engajamento mútuo pode ser estimulado entre mediadores de espaços de Educação Não Formal, bem como para analisar o desenvolvimento potencial de brokers que possam atuar em outros contextos profissionais.

A Teoria de Comunidade de Prática mostra-se, assim, como um referencial promissor para o entendimento e a promoção do processo formativo de educadores, bem como para o desenvolvimento de relações e vínculos mais estáveis entre os diferentes contextos de formação inicial do licenciando em Ciências. 


\section{REFERÊNCIAS ${ }^{21}$}

AFONSO, A. M.; CARVALHO, A. M. P. de; SASSERON, L. H. Alfabetização científica dos alunos em diferentes contextos escolares. In: XIX Simpósio Nacional de Ensino de Física - SNEF, Manaus, AM, 2001.

ALLARD M., LAROUCHE. M. C.; LEFEBVRE, B.; MEUNIER,A.; VADEBONCOEUR, G. La visite au Musée. In: Réseau. Canadá, p. 14-19, 1996.

BAILEY, E. B. How Museum Educators Build and Carry out Their Profession: An Examination of Situated Learning within Practice. Tese de doutorado em Filosofia, Lesley University, Cambridge, MA. 2003.

BALDINI, L. A. F.; CYRINO M. C. de C. T. Formação de professores de matemática em uma Comunidade de Prática ao utilizar o software GeoGebra. In: Actas de la Conferencia Latinoamericana de Geogebra. Uruguai, 2012.

BARROS, S. S. Metodologias da observação e da pergunta nas exposições. Caderno do Museu da Vida: O formal e o não-formal na dimensão educativa do museu. Museu da Vida FIOCRUZ e Museu de Astronomia e Ciências Afins - MCT, Rio de Janeiro, p. 36-45. 2002.

BELINE, W. Formação de professores de matemática em comunidades de prática: um estudo sobre identidades. Tese de doutorado em Ensino de Ciências e Educação Matemática do Centro de Ciências Exatas da Universidade Estadual de Londrina, Londrina, 2012.

BERELSON, B. Content analysis. In: Communication Research. New York: University Press, 1952.

BIZERRA, A. F. Atividade de aprendizagem em museu de ciência. Tese de doutorado em Educação, Universidade de São Paulo, São Paulo, 2009.

BOGDAN, R. C. e BIKLEN, S. K. Investigação Qualitativa em Educação. Porto Editora, LDA. Porto - Portugal. 1994.

BRASIL. Lei $N^{\circ} 13.005$, de 25 de junho de 2014. Aprova o Plano Nacional de Educação PNE. Congresso Nacional, Brasília, 2014. Disponível em: http://fne.mec.gov.br/images/doc/pne-2014-20241.pdf. Acessado em: 22 de set. de 2014.

\footnotetext{
${ }^{21}$ De acordo com a Associação Brasileira de Normas Técnicas.
} 
CAISCAIS, M. G. A; TERÁN, A. F. Educação formal, informal e não formal em ciências: contribuições dos diversos espaços educativos. In: XX Encontro de Pesquisa Educacional Norte Nordeste (XX EPENN), UFAM, Manaus, AM. 2011.

CAZELLI, S.; MARANDINO, M. STUDART, D. Educação e Comunicação em Museus de Ciências: Aspectos históricos, pesquisa e prática. In: GOUVEA, G.; MARANDINO, M.; LEAL, M. C. (Org.). Educação e Museu: a Construção Social do Caráter Educativo dos Museus de Ciências. Editora Access/Faperj. Rio de Janeiro, p.83-106. 2003.

COX, A. What are communities of practice? A comparative review of four seminal works. Journal of Information Science, vol. 31, n.6, p. 527-540, UK, 2005.

CYRINO M. C. de C. T.; CALDEIRA, J. S. Processos de negociação de significados sobre pensamento algébrico em uma Comunidade de Prática de formação inicial de professores de matemática. Investigações em Ensino de Ciências, vol.16(3), p.373-401, Porto Alegre, 2011.

GIL, A. C. Métodos e técnicas de pesquisa social. 6ª Edição. Editora Atlas. São Paulo. 2008.

GOHN, M. G. Educação não-formal, participação da sociedade civil e estruturas colegiadas nas escolas. Ensaio: aval. pol. públ. Educ., Rio de Janeiro, v.14, n.50, p. 27-38, jan./mar. 2006.

GOUVÊA, M. T. A. de; PARAnhos, C. ; MOTTA, C. L. R. da. Promovendo o aprendizado organizacional por meio de comunidades de prática. B. Téc. Senac: a R. Educ. Prof., Rio de Janeiro, v. 34, n.3, set/dez. 2008.

KRASILCHIK, M. Reformas e realidade: o caso do ensino de ciências. São Paulo em perspectiva, 14(1), São Paulo, 2000.

LAVE, J. e WENGER, E. Situated Learning: Legitimate Peripheral Participation. Cambridge, UK: Cambridge University Press. 1991.

LÜDKE, M. e ANDRÉ, M. E. D. A. Pesquisa em Educação: Abordagens Qualitativas. Editora Pedagógica e Universitária LTDA. São Paulo -SP. 1986.

MARANDINO, M. A ação educativa, aprendizagem e mediação nas visitas aos museus de ciências. Workshop sul-americano \& escola de mediação em museus e centros de ciência. Rio de Janeiro: Museu da Vida/Casa Oswaldo Cruz/Fiocruz, 2008. 
MARANDINO, M. Museus de Ciências como Espaços de Educação. In: Museus: dos Gabinetes de Curiosidades à Museologia Moderna. Belo Horizonte: Argumentum, p. 165-176. 2005.

MARANDINO, M.; BIZERRA, A.; NAVAS, A. M.; FARES, D. C.; STANDERSKI, L.; MONACO, L. M.; MARTINS, L. C.; SOUZA, M. P. C. de; GARCÍA, V. A. R. Educação em museus: A mediação em foco. São Paulo, SP: Geenf / FEUSP, 2008.

MARANDINO, M.; SILVEIRA, R. V. M.; CHELINI, M. J.; FERNANDES, A. B.; RACHID, V.; MARTINS, L. C.; LOURENÇO, M. F.; FERNANDES, J. A.; FLORENTINO, H. A. A Educação Não Formal e a divulgação científica: o que pensa quem faz? In: IV Encontro Nacional de Pesquisa em Educação em Ciências (IV ENPEC). Bauru, SP. 2003.

MASSARANI, L. e ALMEIDA, C. Apresentação. In: Workshop sul-americano \& escola de mediação em museus e centros de ciência. Museu da Vida/Fundação Oswaldo Cruz (Fiocruz), Rio de Janeiro, 2008.

MELLO, C. de; WILDERMUTH, S.; VAUGHAN, A. G.; CHRISTO-BAKER, E. A. A path to passion: connecting personality, psychological conditions, and emotional engagement. Jornal of Psychological Issues in Organizational Culture, vol.3, n.4, Bridgepoint Education, Inc. and Wiley Periodicals, Inc. Published online in Wiley Online Library, 2013.

MINAYO, M. C. de S. Técnicas de Pesquisa. O Desafio do Conhecimento - Pesquisa Qualitativa em Saúde. 9a Edição. p.261-297. Editora HUCITEC. São Paulo - SP. 2006.

MISKULIN, R. G. S.; SILVA, M. da R. C. e ROSA, M. Formação continuada de professores de matemática: o desenvolvimento de comunidades de prática baseadas na tecnologia. Revista Iberoamericana de Tecnología en Educación em Tecnología, n.3, Argentina, 2009.

MÔNACO, L. M. O setor educativo de um museu de ciências: um diálogo com as comunidades de prática. Tese de doutorado em Educação, Universidade de São Paulo, São Paulo, 2013.

MOREIRA, A. M. Pesquisa básica em educação em ciências: uma visão pessoal. Revista Chilena de Educación Científica, 3(1): 10-17, 2004. Disponível em: http://www.if.ufrgs.br/ moreira/Pesquisa.pdf. Acessado em: 18 de mar. de 2013.

MOSER, A. Formação docente em comunidades de prática. Revista Intersaberes, a.5, n.10, p.210-244, Curitiba, 2010. 
PICCININI, C.; MARTINS, I. Comunicação multimodal na sala de aula de ciências: construindo sentidos com palavras e gestos. Ensaio Pesquisa em Educação em Ciências, América do Norte, 2008.

QUEIRÓZ, G.; KRAPAS, S.; VALENTE, M. E.; DAVID, E.; DAMAS, E. E FREIRE, F. Construindo Saberes da Mediação na Educação em Museus de Ciências: $O$ Caso dos Mediadores do Museu de Astronomia e Ciências Afins/ Brasil. In: I Encontro Iberoamericano sobre Investigação em Educação em Ciências, Burgos, Espanha, 16-21 de set. 2002.

ROCHA, S. C. B. da. A escola e os espaços não-formais: possibilidades para o ensino de ciências nos anos iniciais do ensino fundamental. Dissertação de mestrado em Educação e Ensino de Ciências na Amazônia, Universidade do Estado do Amazonas, Manaus, 2008.

ROGERS, A. Looking again at non-formal and informal education - Towards a new paradigm, 2004. Disponível em: 〈http://www.infed.org/biblio/non_formal_ paradigm.htm> Acessado em: setembro 2007.

SASSERON, L. H. Alfabetização científica no Ensino Fundamental: estrutura e indicadores deste processo em sala de aula. Tese de doutorado em Educação, Universidade de São Paulo, São Paulo, 2008.

SMITH, M. Non formal education. Disponível em < http://www.infed.org/biblio/bnonfor.htm > 1996. Acessado em: agosto 2012.

SONG, J. H.; KOLB, J. A.; LEE, U. H.; KIM, H. K. Role of transformational leadership in effective organizational knowledge creation practices: mediating effects of employees' work engagement. Human resource development quarterly, vol.23, n.1, Wiley Periodicals, Inc. Published online in Wiley Online Library, Spring, 2012.

TEIXEIRA, J. N. Categorização do nível de letramento científico dos alunos de Ensino Médio. Dissertação de mestrado em Ensino de Ciências, Instituto de Física, Instituto de Biociências, Instituto de Química e Faculdade de Educação da Universidade de São Paulo, São Paulo, 2007.

VALENTE, M. E. A. O museu de ciência: espaço da História da Ciência. Ciência e Educação, v.11, n.1, p. 53-62, 2005.

VAN-PRAET, M. e POUCET, B. Les Musées, Lieux de Contre-Éducation et de Partenariat Avec L'École. In: Education \& Pédagogies - dés élèves au musée, n.16, Centre International D’Études Pédagogiques, 1992. 
WENGER, E. Communities of practice: a brief introduction. Jun. 2006. Disponível em: http://www.ewenger.com/theory/. Acessado em: 22 de mar. de 2013.

WENGER, E. Community of practice: Learning, meaning, and identity. Cambridge University Press. Nova York, EUA. 1998.

WENGER, E.; SNYDER, W. M. Communities of practice: the organizational frontier. Cambridge : Harvard Business School Press, Jan.,/Feb., p.139-145, 2000.

WENGER, E. (TEAM B). What is a community of practice? Dez. 2011. Disponível em: http://wenger-trayner.com/resources/what-is-a-community-of-practice/. Acessado em: $06 \mathrm{de}$ jul. de 2014.

YIN, R. K. Estudo de Caso: Planejamento e Métodos. $2^{\text {a }}$ Edição. Editora Bookman. Porto Alegre. 2001. 


\section{ANEXO A - Transcrições das Entrevistas com os Mediadores}

São Paulo, 15 de Junho de 2012.

\section{Entrevista com mediador Veterano 1 (V1) da Estação Biologia.}

Turno 1: [Entrevistador]: Então, hoje é dia 15 de junho. É... Por que escolheu fazer graduação em biologia?

Turno 2: [Mediador V1]:" É... por causa do meu avô. Olha só...o meu avô gostava muito de plantas, ele tinha quintal que eu cuidava dele, o quintal, e eu me interessei. Eu...gosto mais de plantas do que de biologia. (risos) E eu já tinha interesse em ser professor e eu precisava de alguma disciplina né, pra ser professor.

Turno 3: [Entrevistador]: Então você já entrou querendo dar aula?

Turno 4: [Mediador V1]: Sim. Eu achei que biologia poderia ser uma boa disciplina.

Turno 5: [Entrevistador]: E por que escolheu fazer na USP?

Turno 6: [Mediador V1]: É...porque...olha só, porque é perto, né. Porque pelo cursinho que eu fiz eu sabia que tinha condições de fazer, mas eu tinha perspectivas, se eu fosse fazer fora né, daqui de São Paulo, eu ia querer só pela experiência de morar fora. Mas como eu não passei na Unicamp, eu fiquei aqui.

Turno 7: [Entrevistador]: Meio que deu certo.

Turno 8: [Mediador V1]: Exatamente. Eu acho que a universidade é boa em qualquer lugar aqui. Não tem aquele mito né, ah...

Turno 9: [Entrevistador]: Entendi. E você faz licenciatura e bacharelado?

Turno 10: [Mediador V1]: Uhum.

Turno 11: [Entrevistador]: É qual área que tem mais interesse? Botânica?

Turno 12: [Mediador V1]: Botânica e ensino.

Turno 13: [Entrevistador]: E ensino.

Turno 14: [Mediador V1]: Tá meio a meio assim. Tá difícil de escolher. (risos)

Turno 15: [Entrevistador]: Ué, faz ensino de botânica (risos). Antes de entrar na USP ou agora que você está... Você já trabalhou em alguma coisa? Pode ser relacionado à educação ou não.

Turno 16: [Mediador V1]: Humm. Já trabalhei com educação ou não?

Turno 17: [Entrevistador]: É pode ser assim, ah, trabalhei com meu pai em alguma coisa.

Turno 18: [Mediador V1]: Ah, deixa ver então. Trabalhei um tempo de temporário em loja, final de ano, contrato temporário. Só isso. 
Turno 19: [Entrevistador]: $\mathrm{Na}$ área da educação nada.

Turno 20: [Mediador V1]: Não.

Turno 21: [Entrevistador]: Nem aqui durante a USP, não teve nenhum projeto que você foi voluntário? Iniciação científica?

Turno 22: [Mediador V1]: Não. Eu comecei a minha iniciação, comecei a me aproximar do laboratório formal né, em agosto do ano passado. Agosto de 2011 eu comecei na sistemática vegetal.

Turno 23: [Entrevistador]: Humm. Tá lá ainda?

Turno 24: [Mediador V1]: To lá ainda. Mas é que eu não montei meu projeto de iniciação, tô protelando um pouco, vou montar agora né.

Turno 25: [Entrevistador]: Entendi. E você tá quanto tempo na EB?

Turno 26: [Mediador V1]: Desde que eu entrei na bio.

Turno 27: [Entrevistador]: 4 anos?

Turno 28: [Mediador V1]: É. Que é o costume né. Entrar e já...

Turno 29: [Entrevistador]: Quando você entrou tinha já esse aspecto de fazer a semana de treinamento?

Turno 30: [Mediador V1]: (Acena com a cabeça que sim).

Turno 31: [Entrevistador]: E como foi esse processo de formação? Você lembra, uma das primeiras visitas? Como é que foi isso? Você teve a semana de treinamento e depois pra você se tornar o que você é hoje, porque você é praticamente o cabeça né da biologia agora?

Turno 32: [Mediador V1]: É mais ou menos. É... na verdade, esse é um ponto muito mais pra frente né, mas na verdade o cabeça agora é o Mediador V2. Outra pessoa, no caso está no terceiro ano, eu já tenho outra posição né, já virei um membro velho, né (risos). Ele que é o elemento central. Administrativamente ele é central. Se pensar em termos de espírito do grupo, pode ser que eu ainda esteja nessa posição, mas administrativamente é ele. Coitado (risos)! É mais é essa coisa do velho né. O velho tem essa posição, né.

Turno 33: [Entrevistador]: Que posição?

Turno 34: [Mediador V1]: Ah, essa posição central de ah... O que é a EB? Ah... A referência né, cultural e mental assim fica na pessoa velha, né. Quando eu entrei, por exemplo, né, eu tava em 2009, né, e uma veterana de 2006 que estava no quarto ano, né, era a tia M e o tio M, eles eram o espírito do negócio né. Eles não estavam no centro do furacão né. Quem estava no centro do furacão era o pessoal do terceiro ano, mas quando pensava em CV né, nome antigo, 
você pensava neles. Então virei isso agora. E daí meu processo de treinamento... Eu não lembro mais... Deixa eu ver aqui. Vai me perguntando que daí eu lembro.

Turno 35: [Entrevistador]: Você se identifica então como uma referência lá na EB?

Turno 36: [Mediador V1]: Sim.

Turno 37: [Entrevistador]: E como é essa passagem, se é que a gente pode chamar de passagem, mas como é assim essa transposição do que você conhece, do que você entende de EB pros novatos?

Turno 38: [Mediador V1]: Hum... Certo. Isso se dá, principalmente no treinamento, né, ai é um troço muito de pai pra filho assim, é engraçado (risos). Se dá muito no treinamento, mas é como se fosse no papo de tradição assim sabe, que quando os veteranos falavam pra gente, a gente até ficava arrepiado, assim. É como sei lá, se tivesse sei lá, numa roda, assim, família e ai seu avô fala assim né: ah porque no meu tempo né. A gente fala nossa, que legal. Fica arrepiado né. E ai é basicamente assim né. Então, esse momento de transmissão né, ah o que eu entendo por EB rola no treinamento, né que a gente fala. Mas também em certos momentos, sei lá, de repente a gente ta numa reunião né, falando de coisas administrativas, ah a gente tem que comprar tantos borrifadores para semana que vem, mas de repente a reunião entra pra um tema mais polêmico, dai para tudo a reunião e alguém mais velho faz uma fala assim, ah sobre o espírito de $\mathrm{CV}$, né. E dai é nesse momento que acontece né.

Turno 39: [Entrevistador]: O que significa CV mesmo?

Turno 40: [Mediador V1]: Comissão de visitas. Antigo nome. E é isso. Acontece quando está bastante reunido assim e de repente assim.

Turno 41: [Entrevistador]: Então é momentâneo assim. O que acontece no momento é uma brecha para você passar essas coisas?

Turno 42: [Mediador V1]: Sim. É.

Turno 43: [Entrevistador]: E na sua formação, vê se você consegue lembrar assim, como era a relação entre você e o veterano, você tinha um veterano que era a referência, ou você tentava se pautar em vários, pra montar sua fala. Porque quando a gente entrevistou os novatos a gente vê que eles ainda estão naquela fase de observação, né. Poucos têm a coragem e de ir lá falar na frente. E pra que ele fale lá na frente ele tem que montar uma fala e como que, você lembra assim, como é que foi essa construção da sua fala nas primeiras visitas assim? Foi conhecimento seu que você trouxe, foi uma mescla de várias coisas, como é que foi isso? 
Turno 44: [Mediador V1]: Tá. É tinha veteranos de referência, né, por exemplo, esses que eu citei né, tia M., tio M. e a tia N. foi um elemento central na minha formação que a tia N. era do terceiro ano né. Agora, hoje em dia ela é professora da rede pública. E eu me pegava assim, ouvindo o curso deles, eles falando e eu reproduzindo. Não partiam dos conhecimentos meus, de vez em quando né, tinha bicho né, e eu sabia pouca coisa. É... Olhava o que eles falavam e reproduzia.

Turno 45: [Entrevistador]: Mas reproduzia você diz, assim, igual ou você colocava alguma característica tua?

Turno 46: [Mediador V1]: Geralmente... Deixa eu ver. Em termo de conteúdo basicamente eu reproduzia, no máximo eu juntava né, o que o veterano falava com o outro. Mas o que tinha de meu assim, talvez fosse... Não sei como que chama. Talvez a abordagem. Sei lá. A inspiração são os alunos né, é... Não sei como falar isso. Mas, por exemplo, se meu veterano do terceiro ano, pela personalidade dele, ele falava de um jeito mais contido, eu falava de um jeito, sei lá, mais espontâneo, porque é da personalidade né. Mas a forma como eu abordo as coisas né, é praticamente igual, por exemplo, se um veterano meu, sei lá tia M., ela gostava muito de indagar os alunos né. Tipo e fortemente assim, indagar fortemente. Ah, mas porque você acha que essa planta suculenta é assim? Por que... O que você acha né. Eu... Copiava $\operatorname{assim...~}$

Turno 47: [Entrevistador]: E hoje em dia? Como é isso? Isso mudou? Tem coisa que você ainda traz? Como é que é a sua fala hoje em dia?

Turno 48: [Mediador V1]: Deixa eu ver. É minha fala hoje em dia tá influenciada pelas minhas matérias que eu fiz, basicamente.

Turno 49: [Entrevistador]: Então você traz bastante conhecimento teu? Mas você acha que ainda continua alguma coisa do que você fazia lá? Você acha que você mudou completamente o jeito de falar ou você acha que foi só tipo uma evolução? Você foi tipo, transformando pra melhor?

Turno 50: [Mediador V1]: Acho que com o tempo mudaram né, tem mais coisa que vem de mim, né, das minhas matérias. Mas na abordagem assim, acho que manteve muito. Essas raízes assim que eu aprendi com meus veteranos do quarto ano, de perguntar bastante, de instigar bastante, acho que se manteve.

Turno 51: [Entrevistador]: Por que você decidiu entrar na EB?

Turno 52: [Mediador V1]: Antes de eu me matricular na biologia né, eu era pré bicho tinha uma veterana do segundo ano, que é a Ma né, a Ma tava pegando folha de bicho pau. Daí eu 
não era nem matriculado ai ela falou, ah vem me ajudar. Falei, ah que legal né, vamos ver o que é isso ai. E daí na semana do bicho a gente é apresentado aos projetos da bio né, no primeiro dia que você ta aqui, você é apresentado. Ah, vai conhecer a Estação Biologia, vai conhecer a atlética, essas coisas. E dai eu falei, putz, maravilha. Ensino e eu gosto de ensino, então, eu fui. Basicamente.

Turno 53: [Entrevistador]: Legal. Você é bolsista na EB?

Turno 54: [Mediador V1]: Sim.

Turno 55: [Entrevistador]: Eu sei que vocês não tem função fixa lá, mas qual é a sua função assim... Que você mais faz ali, além de ser um ponto de referência pros novatos, o que mais você faz?

Turno 56: [Mediador V1]: Essa questão do bolsista é bem maluca.

Turno 57: [Entrevistador]: Você já é bolsista há quanto tempo lá?

Turno 58: [Mediador V1]: Há dois anos e meio. Inclusive a gente estabelece um regulamento interno, no máximo fica dois anos né. E eu to... (risos)...

Turno 59: [Entrevistador]: No limiar...

Turno 60: [Mediador V1]: É. O bolsista né, eu né, basicamente eu faço, é..., mas isso é meio pela minha personalidade. A gente nunca chegou a um consenso muito grande do que um bolsista faz né. E os nossos veteranos, né, não passaram uma definição muito clara, também. Então, eu acho assim, que algumas dessas definições do que é ser bolsista, meio que eu que inventei e passei pro resto do pessoal (risos). Porque nunca ficou muito claro pra gente né. A gente sabia que o bolsista era o cara que trabalhava mais né, em termos bem simples assim. Ele trabalha quatro horas a mais. Se o voluntário se compromete em fazer um período de visita, o bolsista se compromete a dois, basicamente né. E se um voluntário tem que fazer um determinado número de manutenções de animais, que a gente faz em escala né, num mês a gente tem uma escala, por exemplo, precisa cuidar do bicho pau, sei lá é..., dá quinze vezes por mês né, pra cuidar do bicho pau. Se a gente tiver quinze monitores, uma vez por mês um monitor tem que ir lá cuidar do bicho pau. Isso é um acordo comum. O bolsista tem que fazer, a gente entrou em acordo, mais ou menos o dobro, em termos temporais né, termos oficiais o bolsista tem que trabalhar o dobro do tempo.

Turno 61: [Entrevistador]: E qual a frequência que você vai na EB? Já que você é bolsista você não vai só na sexta?

Turno 62: [Mediador V1]: É, então, eu vou em dois períodos, né, sexta de manhã e sexta a tarde. 
Turno 63: [Entrevistador]: Ah tá.

Turno 64: [Mediador V1]: Mas além dessa coisa formal né, tem a responsabilidade informal né. Pelo que a gente entendeu dos nossos veteranos, a gente entendeu que os bolsistas é que tocam o barco né. Hoje a gente tá vendo que essa não é uma boa abordagem, a gente vê que, inclusive no mês passado né, a gente tava sentado os bolsistas e falou, cara, não é bem assim né, não é só os bolsistas que tocam o projeto né, e isso seria até um pouco injusto né. E eles estavam até, os monitores que são veteranos né, não bolsistas, ou seja, voluntários, eles estavam se sentindo marginalizados (risos). Talvez não seja isso a ideia certa né, a se fazer. Eles estão se sentindo marginalizados e tipo na hierarquia no projeto né. Isso não é legal. Dai a minha definição pessoal de bolsista, não sei até que ponto se eu vou transmitir isso pros outros anos, mas a minha definição pessoal é que o bolsista né, como ele recebe né, ele tem que fazer trabalhos é... Tipo trabalhos que não acrescentam, tipo se houver algum trabalho a ser feito no projeto né, na EB, que não acrescenta nada a ninguém, é... Isso é trabalho do bolsista. Por exemplo, né, é... Porque tem trabalhos que acrescentam e tem trabalhos que não, por exemplo, inventar uma atividade, criar uma atividade didática sobre abelhas, putz, isso traz crescimento pessoal né. Interessante pra caramba né, mas o dia a dia do projeto não é sempre fazer as coisas interessantes né, às vezes, um dos trampos né, um dos trabalhos é, sei lá, escanear questionários.

Turno 65: [Entrevistador]: Esse é o trabalho do bolsista?

Turno 66: [Mediador V1]: É, então, isso não acrescenta nada a ninguém. Não acrescenta em nada fazer isso. Bom, é justo que o bolsista faça isso, já que ele ta recebendo.

Turno 67: [Entrevistador]: Entendi. É... Você já deve ter participado de muitas visitas. Você consegue identificar uma que te marcou mais, uma experiência assim... Primeiro, você gosta de trabalhar mais com público do ensino médio, do fundamental, ou infantil, qual que é sua preferência?

Turno 68: [Mediador V1]: Eu acho que eu prefiro o pessoal do fundamental... É difícil, eu não tenho uma grande preferência assim, eu sempre vejo desafios diferentes assim. É... Parece uma resposta meio de pilantra né (risos), mas é que é muito diferente não tem... E como não é, tem tanta frequência a gente acaba não cansando de um tipo né. Sei lá, não consigo dizer se eu tenho uma preferência.

Turno 69: [Entrevistador]: E teve alguma visita que te marcou assim, e algum motivo especial para ela ter te marcado?

Turno 70: [Mediador V1]: Eu não lembro. Minha memória é muito ruim. 
Turno 71: [Entrevistador]: Ok. (risos). Qual atividade que você mais gosta lá da EB?

Turno 72: [Mediador V1]: Eu gosto de ir pro jardim.

Turno 73: [Entrevistador]: Que é a da biodiversidade né?

Turno 74: [Mediador V1]: É. Eu queria que tivesse mais atividades no jardim. Eu fiquei de inventar uma de botânica, mas não inventei. Mas acho que o jardim é legal, sei lá, porque tem botânica, a minha atividade que eu gosto de fazer sempre é suculentas, de biodiversidade. Eu não acho que ela é uma atividade assim, pedagogicamente interessante. Ela é altamente expositiva né. Tem um pouquinho de investigação, mas é porque é planta. Planta é legal. Pedagogicamente assim né, tipo se a atividade é interessante assim...

Turno 75: [Entrevistador]: Ah, mas por ser em outro espaço né, de repente por a gente estar falando em São Paulo, de repente uma criança não tem tanto acesso a jardins, a planta, a bicho... É uma área diferente, realmente. É... Pra você qual é o objetivo da Estação Biologia?

Turno 76: [Mediador V1]: Olha só (risos). É... Essa é uma boa pergunta. Ano passado eu tava em crise com relação a isso e até convoquei os veteranos de 2006, chamei um de 2004 e... Só os veteranos né, bicho não são a fim de ir. Mas teve uma reunião assim, que eu falei: galera, qual que é o objetivo da EB né? Eu não sei o objetivo, eu to aqui um tempo e não sei. E eu falei: vocês sabem? Eu perguntei pra eles. E foi um dia que nossa, sai de lá arrepiado. Foi bonito. Eu senti que os veteranos tinham esse objetivo na cabeça. Eu que não tinha né. Eles sempre me passaram, mas não me convenciam. Eu perguntei, pô, qual é o público preferencial da EB? A forma que a gente se organiza, ela é boa? Ou seja, entre alunos e tal. A estrutura da EB tipo, é válida para os alunos? Não seria mais fácil fechar a EB e destinar a verba que a gente ganha pra Estação Ciência? Eu perguntei isso, na cara assim né. Qual é que é né? E eu peguei também... Isso foi uma madrugada que eu não dormi. Eu peguei um papel e, eu sou muito cartesiano né, então eu gosto de estabelecer prioridades, se a gente fosse pensar em três objetivos né, da EB, qual seriam eles e tipo ranquear. E depois eu fiz e discuti com o pessoal. Eu cheguei nisso né, objetivo da EB, o primeiro seria atender crianças né, ou seja, atender alunos e com muitas aspas promover crescimento neles, com muitas aspas. O segundo objetivo né, menos importante, tão importante, mas menos do que o primeiro, segundo seria formar monitores, e acho isso... E o terceiro objetivo que é bem obscuro e esse é bem pessoal é ser um núcleo da licenciatura na biologia. Ó que maluco (risos). Mas isso é porque eu gosto de licenciatura né. 
Turno 77: [Entrevistador]: Mas por que você acha isso? Por que você acha que a EB é um centro de formação de mediadores, é um local de formação de mediadores? E por que seria um núcleo da licenciatura? Qual é a conexão ai?

Turno 78: [Mediador V1]: Tá, vamos lá. Essa pergunta faz muito sentido porque, principalmente porque muita gente ta lá como monitor não quer licenciatura, né. E muita gente da licenciatura não quer (risos).

Turno 79: [Entrevistador]: Estar na EB.

Turno 80: [Mediador V1]: É... Não quer ser monitor. Por isso que eu fico falando, cara o porquê né. É... Eu diria que o tema é comum, né. Tipo ah, porque o objetivo é comum né. Por exemplo, se na EB o primeiro objetivo é promover o crescimento dos alunos né, é o objetivo central, isso também é objetivo do pessoal da licenciatura. O cara vai dar aula, vai estar num ambiente formal, mas o objetivo dele é promover crescimento dos alunos né. Então acho que esse objetivo já une né. E... Tem essa relação porque são pessoas né, entendeu. E eu sinto que isso ficou bem claro naquele papo pedagógico da terça-feira. Que é um lugar que tem pessoas né, e como a gente tem certa liberdade, a gente pode ir lá, tirar o sapato e ouvir um rock in roll lá, que não vem ninguém atazanar a gente né. Eu acho que é um lugar pras pessoas se conhecerem né, e ocasionalmente trocar uma ideia. Sei lá, é importante ter esse lugar. De repente... Porque os lugares né, agora que eu to na licenciatura eu vejo, o pessoal que gosta de licenciatura não tem um espaço pra isso né, um espaço informal. No máximo tem aquela aula, é uma aula, sei lá, a aula do Paulo Sano, ela tem bastante discussão né. Ah mas você tá discutindo né, ah, você ta com seu colega que é da licenciatura, que se interessa também, mas você vai falar alguma coisa, vai trocar uma ideia com ele, mas tem um professor te olhando né (risos). Você fica um pouco inibido né. E lá não né. E... Sei lá, até o Labliq, o Labliq existe né, pro gravador, é o laboratório da licenciatura (risos). É... Mas não posso tirar o sapato lá, não posso ouvir um rock in roll lá. É um espaço fechado, tem um professor lá orientador né, e na EB não. É um lugar aberto né, beleza que ele é focado pros monitores né, mas tá aberto lá. Eu posso tirar o sapato, posso ta falando de qualquer coisa né, falando de futebol e de repente eu falo opa, Vygotsky. Falo de Vygotsky no meio de um papo de futebol. E tá ótimo... Eu acho que é isso.

Turno 81: [Entrevistador]: Tem essa descontração e uma coisa mais...

Turno 82: [Mediador V1]: E quando a gente estava discutindo objetivos né, é... Eu cheguei lá na EB com esse papelzinho e falei: oh galera, eu acho que o objetivo primordial é a formação de monitores, e o role dos alunos é secundário. Eles me convenceram que eu tava errado. 
Turno 83: [Entrevistador]: De que primeiro é essa parte dos alunos.

Turno 84: [Mediador V1]: Exato.

Turno 85: [Entrevistador]: Eu já te perguntei isso informalmente, mas é... Você acha, considera a Estação Biologia um espaço de Educação Não Formal ou é só um projeto de extensão universitária?

Turno 86: [Mediador V1]: Tá! Essa foi uma das perguntas da angustia né. (risos). Do nosso papo fumado né, porque é muito maluco assim. Eu perguntei isso pros meus veteranos. Eu falei: pô, a gente, como é que a gente se configura né? Tipo e eu senti muitos problemas quando eu tive que fazer divulgação né. Que eu fiquei responsável pela divulgação e eu não sabia o que falar. Ah, venha para Estação Biologia, nós somos um... Um... Eu não sabia o que dizer (risos). Se era um museu, se era um parque, se era um espaço de ciência. E eu já não sei. Não sei dizer. Eu não sabia né e eu fiquei com a resposta da minha veterana né. Ela que me criou, ela me deu essa resposta e eu anote, é um mosaico né, é uma mistura entre espaço de Educação Não Formal e é uma mistura entre isso e um... Como chama... Um espaço de ciência. E eu não sei exatamente se isso existe né. E é meio maluco assim, às vezes, eu fico meio angustiado.

Turno 87: [Entrevistador]: Como é a relação da Beatriz com vocês? Não só a Beatriz, mas o docente que... Não sei se foi sempre ela, deve ter tido outros professores responsáveis. Mas como que é... Eu vejo que vocês são muito autônomos, como que a relação, essas dúvidas, vocês colocam pra ela?

Turno 88: [Mediador V1]: Não, não.

Turno 89: [Entrevistador]: E porque não?

Turno 90: [Mediador V1]: É... A nossa relação com o professor responsável né, eu peguei a gestão antiga, que era o professor Luiz Fábio, também da zoologia. E eu era bicho né, mas eu sentia que era... Era... Como chama? Administrativa né, a interação né. Ah, a gente precisa de cinco borrifadores novos, compra ai pra nós né. Com a Bia isso mudou um pouco, mas não muito né. A gente discute alguns projetos em comum, mas não. Por que a gente não coloca né, isso pra ela? Primeiro porque a gente tem pouco tempo assim, com ela né. Geralmente a gente marca reunião e não tem hora certa com ela né. Às vezes marca ou tem tipo... A frequência de reuniões com a orientadora é muito pequena. Mesmo quando a gente tinha o Luiz Fábio né, Luiz Fábio também era um cara muito ocupado né, e a gente fazia reunião de quinze minutos. Tinha que ter capacidade de resolver tudo em quinze minutos né. E pra você discutir objetivo do projeto né, você precisa, sei lá, sentar numa mesa de bar né e ficar um tempão discutindo. 
Então, a gente não discuti essas coisas porque ela não apresentou esse tempo pra conversar com a gente e talvez ela não esteja contextualizada pra isso né.

Turno 91: [Entrevistador]: Contextualizada porque ela não é professora de ensino? Ela é professora de que, a Beatriz?

Turno 92: [Mediador V1]: Ela é da fisiologia. Então, é meio que as duas coisas. É porque ela não tá na área de ensino né, mas até tudo bem sabe. Se fosse um cara do segundo ano, que cursa licenciatura ele vai estar contextualizado, porque contextualizado tipo no dia a dia. Os nossos professores orientadores, por exemplo, eles... Hamilton também, por exemplo, nunca acompanhou a visita, por exemplo. O Luiz Fábio anterior acho que também não.

Turno 93: [Entrevistador]: Por isso eles não estão contextualizados, não conhecem o histórico, a rotina da $\mathrm{EB}$ ?

Turno 94: [Mediador V1]: É, não sabe a rotina.

Turno 95: [Entrevistador]: E você acha que seria interessante a presença... Uma maior presença de um docente ou você acha que isso descaracterizaria a EB?

Turno 96: [Mediador V1]: É isso ai... É eu nunca parei pra pensar nisso ai não. Hum... Não sei, não sei. E mesmo sendo uma professora muito gente boa que nem a Bia ou que nem o Luiz Fábio né, que são pessoas superapreensivas, zoo o time dele assim numa boa né, faz piada. Eu não sei. Boa pergunta.

Turno 97: [Entrevistador]: Então tá, vamos partir pra próxima, num próximo momento eu volto nessa pergunta. (risos) Aproveitando que estamos falando de objetivos né, quais são os pontos fortes e fracos da EB pra você?

Turno 98: [Mediador V1]: A auto-organização né, isso eu digo como participante de movimento estudantil né, a auto-organização é uma faca de dois legumes e sai dai o ponto fraco e o ponto forte, basicamente né. O ponto forte é a autonomia. A autonomia e a convivência tranquila né, como é autogestão, então, ta todo mundo bem lá, todo mundo tranquilo, todo mundo é amigo. E o ponto fraco é que a autogestão traz desorganização e descontinuidade também. Isso é um baita problema. Isso tanto no movimento estudantil e também na EB né, oh que maluco.

Turno 99: [Entrevistador]: Descontinuidade você está falando em relação a... Realmente a continuidade do monitor, ou do trabalho?

Turno 100: [Mediador V1]: Não, do trabalho, por exemplo, é... Sei lá... Enfim, coisas que o pessoal tocava em 2007 né, eu não sei qual era o jeitão que eles tocavam as coisas né, eles podem ter tido iniciativas legais em 2007, que em 2009 tinha morrido já. Apesar de ter 
intermediários né, no meio disso ai, perde né. O tempo médio de duração de uma pessoa na EB pelo que eu fui vendo assim é de dois anos e meio assim. Se eu pegar uma média. E não dava continuidade né, mesmo se tiver um gancho ai no meio dá uma baita descontinuidade. Dá uma descontinuidade do trabalho né, coisas que estão sendo tocadas e na noção da coisa né, no espírito da coisa. O cara de 2007 podia ter uma ideia muito diferente dos objetivos da $\mathrm{CV}$, ele nunca quis conversar. Isso é um problema. A gente tá tentando inverter isso, mas é difícil né, tentando trazer o pessoal do passado pra ir lá conversar com a gente né. Tem esse problema né.

Turno 101: [Entrevistador]: Entendi. Ok. E em você, o que você enxerga de qualidade/habilidade tua que você acha que é funcional lá na EB, que ajuda nos trabalhos da EB?

Turno 102: [Mediador V1]: "Tá, deixa eu pensar. É... Eu acho que eu sou bom pra estruturar o negócio. Eu não sou bom pra fazer, mas (risos) pra estruturar, pra organizar "oh pessoal vamos pensar, sentar e pensar...objetivos né tal. Isso acho que é legal. E... É como é autogestão o negócio né, precisa muito de estruturação cuidadosa né. Isso ai acho que eu dou uma ajuda.

Turno 103: [Entrevistador]: O papo pedagógico foi você quem teve a ideia né?

Turno 104: [Mediador V1]: Eu não sei se essa ideia já tinha surgido antigamente né, mas basicamente fui eu.

Turno 105: [Entrevistador]: E o objetivo do papo pedagógico é...?

Turno 106: [Mediador V1]: (risos) Vamos lá... Ele tem os objetivos claros e os ocultos. (risos). O primeiro... O objetivo principal né, é instrumentalizar os monitores né. Porque como o tempo médio de um monitor é muito curto né, dois anos e meio, muita gente sai da EB antes de entrar na licenciatura. E daí eles vão ter que trabalhar com crianças, eles vão ter que inventar atividade, sem ter nenhuma teoria pedagógica por trás. Isso é um problema. Dai a intenção seria trazer isso né. Trazer isso e instrumentalizar o pessoal. E o objetivo oculto (risos) é mostrar pro pessoal que licenciatura é legal, basicamente. (risos) E tem gente né... E... Enfim, tem gente que chega na EB né, quer ser monitor, é um bom monitor e fala assim: "ah, mas eu não vou querer fazer licenciatura não", mas você olha pro cara, você sabe que ele quer licenciatura, mas ele... Só que ele tem uma visão errada da licenciatura. Então esse é meu objetivo oculto assim.

Turno 107: [Entrevistador]: Mas acho que todo mundo, assim, não todo mundo, mas a maioria das pessoas que entra numa faculdade que tem licenciatura também, entra com uma 
ideia da desvalorização do profissional, do educador né. Eu mesmo fui assim né, eu entrei na biologia, achando que eu fosse fazer só o bacharelado e licenciatura pra caso... Mas quando eu tive contato com a licenciatura eu vi que nossa né... Era o que eu sempre quis, isso tava no meu íntimo, mas eu não conseguia colocar isso pra fora porque tinha todo esse preconceito né, esse nome professor. Eu quando falei pra minha mãe: "Olha assumi, oh mãe vou ser professora e ela meu Deus do céu".

Turno 108: [Mediador V1]: (risos) O que é que eu fiz?

Turno 109: [Entrevistador]: Eu acho que isso ronda né, um pouco.

Turno 110: [Mediador V1]: Mas tem o segundo objetivo oculto também né.

Turno 111: [Entrevistador]: Qual?

Turno 112: [Mediador V1]: Que vai muito com aquele meu terceiro objetivo na EB que é a EB ser um núcleo de licenciatura. Que olha só, eu digo isso como centro acadêmico né, como membro do centro acadêmico. É... A licenciatura precisa ser valorizada né, as pessoas precisam se encontrar, mas sei lá, se o centro acadêmico propõe um espaço né, é... De reunir as pessoas, pode ser até que vá né. Mas não tem aquela substância por dentro né. Não tem aquele calor por dentro né, e... Enfim, e também porque tá mal estruturado o centro acadêmico e a gente não consegue fazer nada atualmente né. Mas não tem aquele calor por dentro e se for a EB propondo, é tem um calor por dentro né, tem pessoas que já estão confirmadas que vão porque estão porque estão mais tempo e, enfim... Tem substância, tem pessoas.

Turno 113: [Entrevistador]: É um... Meio né de...?

Turno 114: [Mediador V1]: Por exemplo, se o centro acadêmico propõe ou sei lá se a comissão de graduação do IB, docentes vão lá e propõe um espaço né, ah... Sei lá o professor Paulo Sano propõe uma roda sobre Vygotsky né, beleza quem vai são os conhecidos entre si né, a gente vai lá e conhece na hora né. Mas se é a EB quem propõe, já tem um núcleo já, entendeu? Então é... Por exemplo, o cara vai lá e fala assim: "ah, vai ter essa roda, ah eu sei que o mediador CF é da EB, vai, ele é meu amigo, então eu também vou". Já tem um núcleo de pessoas conhecidas né. Amiguinhos chamam amiguinhos. (risos).

Turno 115: [Entrevistador]: Ah ok. É... Você participa de elaboração de atividade?

Turno 116: [Mediador V1]: Mais ou menos né. Comecei agora assim. Eu não sou muito bom nisso né. Eu sou bom pra cuidar da burocracia da coisa né. Por exemplo, o meu colega de 2009 conseguiu já criar uma atividade tal. Levou lá pro congresso da genética na praça e eu não né. Agora que eu tô começando. 
Turno 117: [Entrevistador]: E você tá fazendo uma atividade, ta tentando elaborar uma atividade de... As meninas falaram, como é o nome?

Turno 118: [Mediador V1]: De ensino infantil.

Turno 119: [Entrevistador]: De ensino infantil.

Turno 120: [Mediador V1]: A gente chamou de "sentindo a vida", né. É... Tô tentando né. Eu particularmente não vou fazer nada na criação dessa atividade né. Eu tô... Eu inventei que eu tinha que criar, mas quem tá criando mesmo são os bichos.

Turno 121: [Entrevistador]: Ah, entendi.

Turno 122: [Mediador V1]: (risos) Tô aproveitando. É bom porque, pra eles tá sendo muito legal né. E ah... Pra mim, se eu criar uma atividade ou não, pode ser legal. Eu queria criar uma atividade em botânica, isso é minha pilha né. Já até tentei criar, mas é difícil arranjar público pra ela né. É... Eu preciso pensar mesmo. Mas essa atividade ai, eu tô estruturando ela, não tô criando. Quem tá criando são eles né.

Turno 123: [Entrevistador]: Entendi, legal. E só pra terminar essa nossa conversa é... Como você se imagina na EB daqui a seis meses?

Turno 124: [Mediador V1]: Seis meses?

Turno 125: [Entrevistador]: Seus planos? Ou mais pra frente. Pretende continuar, mesmo não sendo bolsista?

Turno 126: [Mediador V1]: É... Agora eu largo e em agosto não sou mais bolsista. Eu me vejo como um velho agora né. Um veteranossauro né.

Turno 127: [Entrevistador]: Veteranossauro (risos).

Turno 128: [Mediador V1]: É... Eu me vejo assim né, participando menos do tramite administrativo né. Ah...correr atrás de bolsa e... Trabalhando, dando esse inicial né, pros mais novos, "não...a EB é isso, esse é o nosso objetivo né" papo de velho chato (risos). Mas eu me vejo agora, só que eu não consigo ficar parado né. Se fosse só isso eu achava muito chato né. Eu me vejo agora num papel de mano da licenciatura. Tipo dar um gás nesse negócio dos papos pedagógicos e ai. E quando o pessoal for criar atividade né, dar um pouco mais de subsídio pra galera. Pô você vai criar... E como eu tive matéria da licenciatura que me deram um pouco mais de norte em tudo isso né, eu vou fazer a mesma coisa com eles né. Tipo matéria de instrumentação, matéria de ensino de botânica que pediram pra fazer atividade ou propor uma aula prática pra molecada né. Eu falei: "ah, fácil né, eu sou da CV e sei fazer isso ai vou propor isso ai tranquilo né". Daí o professor chegava e dava um banho de água fria né. 
Chegava a Alessandra e botava: "qual é o seu objetivo? Qual sua metodologia? Qual sua avaliação?" E como eles ainda não estão na licenciatura né, vou fazer isso com eles.

Turno 129: [Entrevistador]: Legal.

Turno 130: [Mediador V1]: Tava brincando disso agora né. Os bichos estavam com as ideias né: "ah, a gente vai pegar os sons dos passarinhos né e dai a gente pode relacionar assim com várias coisas". Ai eu falei: "Tá. Qual seu objetivo com isso? (risos) Não corta isso ai, isso ai não ta fazendo sentido. Qual a metodologia?" Tem que fazer isso. Limar o cara.

Turno 131: [Entrevistador]: Então você pretende continuar na Estação, mas com essa função de estar orientando eles pedagogicamente?

Turno 132: [Mediador V1]: (risos) E já que... E... Isso não... Sei lá. Não sei se tem uma pergunta sobre isso, ta acabando, mas tem um tópico que é legal assim, que eu pessoalmente bolei aqui um método de organização da EB né, que é diferente da estruturação de uma comissão estudantil, por isso que eu achei interessante né. Como ele é, apesar da descontinuidade e tal, mas entre os monitores que são contidos no tempo tem uma continuidade né, e daí eu imagino um troço meio maluco assim. Isso surgiu num papo que a Alessandra falou ai eu ajeitei, é... Que se você pensar, vou falar de um jeito que faça sentindo depois (risos): oh, pensa num gráfico certo, dai no eixo horizontal, no eixo horizontal se chama centralidade, centralidade no projeto e o vertical se chama tempo, tempo ou experiência. E esse gráfico é assim tipo uma ampulheta, oh que maluco, vai imaginando, não vou desenhar porque vai ser difícil lembrar depois no gravador. É... Uma ampulheta ela é larga na base ela afunila no meio e depois fica larga de novo, certo. Mas ela tem embaixo e em cima. Vamos imaginar um monitor né, qual que é o caminho ideal de um monitor que eu vejo né. Eu bolei isso ai no ano passado, quando eu tive o encontro com os veteranos eu disse: "ah, eu acho que isso é uma estrutura legal pros monitores da EB". O cara entra né e não tem experiência e ele é periférico né, ou seja, ele tá na ampulheta na base né, na base da ampulheta na base larga da ampulheta né. Ele é periférico né. O que significa periférico né, ele não atua diretamente nas coisas centrais. Ele vai, sei lá, fazer uma manutenção de bicho-pau, vai botar um folder num envelope, fazer coisas periféricas né, e não tem experiência né. Ele tá no chão da ampulheta. Dai, conforme ele vai passando o tempo, ele vai ganhando experiência e se tornando mais central no projeto. Requer mais responsabilidades, mas tem mais experiências. Dai, chega um momento que este monitor né, se der sorte, esse monitor vai estar no meio da ampulheta, que ele vai ter um tanto de experiência e vai estar no olho do furacão, é o Mediador V2. O monitor que é isso é o Mediador V2, atualmente né. E ele tá no olho do 
furacão né, ele é o elemento central administrativo do negócio, ele tá ferrado (risos) e ele tem experiência pra isso né. Mas muita coisa ele... Mas ele tem tempo ainda pra crescer, daí vai passar o tempo o cara vai pro quarto ano dele né, daí ele vai... Como ele tem mais experiência né, porque ele passa pelo olho do furacão, ele começa a ficar mais periférico. Se eu olhar pra mim assim eu já sai do centro e tô indo para periferia, só que velho e daí a função. Eu não sou o centro administrativo né, mas eu ainda tenho papel de referência, de referência mitológica do negócio (risos). E é isso né, basicamente. Esse é um percurso bom que eu acho no monitor e quando a gente tem desvios dessa rota ai, a gente tem um monitor problemático né.

Turno 133: [Entrevistador]: E o que você considera um desvio de rota?

Turno 134: [Mediador V1]: Por exemplo, um bicho que entra e sem ter experiência, mas já quer ser central no processo, começa a fazer tudo errado ou o veterano que ele nunca foi pro centro do processo né, e sempre ficou periférico.

Turno 135: [Entrevistador]: O que você acha que faz esse veterano sempre ficar periférico, nunca ficar no centro?

Turno 136: [Mediador V1]: Não se identificar com o projeto, não se identificar com o projeto conta muito. Às vezes ele não...

Turno 137: [Entrevistador]: Você acha que esse veterano tem menos experiência do que o que está no centro?

Turno 138: [Mediador V1]: É daí o problema no meu gráfico né. Eu não sei se a experiência se ganha com o tempo ou se na vivência né. Ai fica o mistério no meu gráfico aqui não deu certo. Mas têm veteranos assim que sempre foram periféricos né, mas se você perguntar alguma coisa ele vai saber responder. Mas ele nunca foi central.

Turno 139: [Entrevistador]: E nesse tempo todo que você tá lá na EB você notou muita gente que entrou e não seguiu essa rota, não chegou nem lá no centro, acabou saindo antes. Você consegue identificar por que deles terem saído antes, alguns motivos? Não deve ter um só né.

Turno 140: [Mediador V1]: É... O motivo é porque, é porque ele não se identificou com a causa do projeto né, mas os motivos centrais eu acho que é porque, às vezes o cara não foi muito mais com a cara do pessoal. É um grupo de amigos né, e amigos muito íntimos e deve não ter ido mais com a cara do pessoal. E outro motivo né, é talvez que ele não tenha se adaptado bem a bagunça. Porque é bagunça lá dentro né, e o cara não aguentou mais: "isso aqui tá muito bagunça, eu gosto de educação, mas tá muito bagunça". Tem amigo nosso que saiu e continua trabalhando com monitoria no museu.

Turno 141: [Entrevistador]: Não conseguiu se adaptar a organização de vocês ali. 
Turno 142: [Mediador V1]: Ah, e tem outra coisa também, o problema da bolsa né. Tem gente que tá no momento de começar a ser central, e quando tá no momento de ser central, a gente não ficou com muita gente porque tinha pouca bolsa né. Tem um número limitado né. E, talvez na época né, e talvez isso meio que sempre, não tava definido o papel de voluntário e de bolsista né, o cara falava: "vou embora então. Um cara que é da minha sala pegou bolsa e eu não, então eu não sei o que eu vou fazer aqui, então vou embora".

Turno 143: [Entrevistador]: E as pessoas, os monitores que estão lá e não querem seguir a licenciatura, não gostam. Você acha que eles estão lá mais por conta dos amigos ou rola uma aprendizagem ali também?

Turno 144: [Mediador V1]: Não sei viu, caramba. Não sei, porque na bio né, tem essa coisa forte né, de você participar de um grupo. Não de um "grupo" (ênfase ao falar grupo), mas de um grupo de projeto de extensão.

Turno 145: [Entrevistador]: Que é apresentado na semana do bicho?

Turno 146: [Mediador V1]: É, ah o cara vai ser semana temática, ou o cara vai ficar na CV né, ou pra Atlética, CA, enfim. E à vezes o cara fica lá, acho que pelos amigos também, mas pela necessidade de se enquadrar em um desses grupos. E às vezes sei lá. Eu nunca entendi essa galera. Eu não gosto de licenciatura, mas eu gosto dos bichos-pau, gosto de fazer a manutenção dos bichos. Nunca entendi essa galera (risos), mas beleza (risos).

Turno 147: [Entrevistador]: E você já viu casos de alguém que entrou lá, nesses quatro anos você já deve ter visto, assim, não sei. De alguém que entrou lá falando que não gostava de licenciatura, que não ia fazer de jeito nenhum ou que só pensava primeiro era o bacharelado, e ai quando viu que tava na aula e gostou daquilo?

Turno 148: [Mediador V1]: Ah caramba. Deixa eu pensar. Eu penso que sim, mas eu não tenho exemplo não, mas eu acho que sim. É que o pessoal do meu ano né, que já tá na licenciatura, eles saíram muito cedo da CV, acabou sobrando só eu e o Paulo.

Turno 149: [Entrevistador]: E saíram por quê?

Turno 150: [Mediador V1]: É... Então. Eu não consigo analisar porque eles eram da minha turma. Só consigo analisar os mais novos. E esses mais novos estão no terceiro agora né. Não entraram na licenciatura direito.

Turno 151: [Entrevistador]: Ah, entendi.

Turno 152: [Mediador V1]: Então, não sei. Eu sei lá. Eu sinto que sim. Acho que tinha veterano que falavam isso sim. Mas, ah lembrei... Minha veterana, a D. Famosa D. né, de 
2007, parece que ela não queria ensino e agora curti ensino, por exemplo. Ah, o... É sei lá. Eu sinto, mas não tenho provas.

Turno 153: [Entrevistador]: Tem alguma coisa que você queira acrescentar?

Turno 154: [Mediador V1]: Eu acho que você tem que entrevistar o veterano V2.

Turno 155: [Entrevistador]: O veterano V2, né?

Turno 156: [Mediador V1]: Porque o veterano V2 né, a gente até já sentou pra conversar sobre isso. Ela tá no meio do furacão, mas esse semestre ele ainda aguenta o furacão. Que nem eu fiz no ano passado, mas ele vai sair do furacão e vai botar outro. É então...

Turno 157: [Entrevistador]: Pro semestre que vem você acha?

Turno 158: [Mediador V1]: Não. No semestre que vem ele continua. Ele vai começar a treinar outro maluco, né. E só... Eu acho muito louco essa diferença entre a $\mathrm{CV}$, projeto de extensão né, e o CA, movimento estudantil, que no movimento estudantil você tem ruptura todo ano. E ai não né, ai você tem continuidade eterna. E talvez seja até legal ver a estrutura da semana temática, que é outro projeto de extensão, que as pessoas... É muito maluco, parece muito, é um projeto de extensão, é um grupo autônomo né, é muita gente, eles ficam amigos muito íntimos, não tem bolsa, ai muda mais né, não tem essa dicotomia bolsista, voluntário, eles ficam... Eles têm uma estrutura pré-planejada já de ficar os quatro anos. Então os papéis são bem estabelecidos. O cara que tá no quarto ano ele sabe que dia, ele sabe que no quinto ano ele vai embora. É muito louco. Eu nunca entrei lá. Nunca fiz parte. Mas é interessante.

Turno 159: [Entrevistador]: Legal. Eu vou entrevistar o veterano V2 mesmo. Eu não sabia que ele realmente era o centro. Pra mim você era... Sempre vejo você muito na ativa.

Turno 160: [Mediador V1]: Não, mas quem trabalha mesmo agora é o veterano V2.

Turno 161: [Entrevistador]: É o veterano V2, tá.

Turno 162: [Mediador V1]: Dá dó do menino (risos).

Turno 163: [Entrevistador]: Então acho que é isso. Muito obrigada.

São Paulo, 07 de Novembro de 2012.

\section{Entrevista com mediador Veterano 2 (V2) da Estação Biologia.}

Turno 1: [Entrevistador]: Bom dia. Vamos começar. Porque você escolheu fazer Biologia?

Turno 2: [Mediador V2]: Desde criança eu gostava muito de ciências e eu falava que queria ser cientista assim e eu não sabia o que de fato um cientista fazia e ai quando entrei no ensino médio é que a disciplina de ciências divide naquelas três áreas né Física, Química e Biologia, 
eu me encantei por Biologia. Ai então eu falei é essa área da ciência que eu quero e ai desde o ensino médio eu já tinha sucesso, assim no primeiro ano que queria fazer Biologia.

Turno 3: [Entrevistador]: Sempre gostou disso então?

Turno 4: [Mediador V2]: Aham

Turno 5: [Entrevistador]: E porque que você escolheu fazer na USP?

Turno 6: [Mediador V2]:Olha isso é uma coisa assim, e... O centro Vi que o curso ah, o pessoal eu sentia no passado que tinha um pouco de preconceito, não preconceito assim, mas olha já que você vai fazer Biologia faça lá, entendeu? Porque se você fizer em outro lugar não é tão bem reconhecido e tal, eu acho que isso pegou bastante assim em mim, tanto é que eu nunca prestei outro vestibular além da FUVEST, foi o único, alias prestei três anos só que foi o único que eu prestei, eu falei: então eu quero fazer lá e não me arrependo não da escolha assim em outras situações que eu já conversei com pessoas de outros cursos e tal, eu percebo que questão de infraestrutura e enfim qualidade de curso eu fui certo. E eu boto fé vi que aqui é bem top.

Turno 7: [Entrevistador]: E você já, você vai poder escolher agora licenciatura ou bacharelado.

Turno 8: [Mediador V2]: Sim.

Turno 9: [Entrevistador]: Você vai fazer os dois, escolher um só?

Turno 10: [Mediador V2]: Vou fazer os dois.

Turno 11: [Entrevistador]: Por que essa escolha?

Turno 12: [Mediador V2]: Então, é... Quando entrei na Bio eu não tinha pretensão de ser professor (risos) acho que a maioria não tinha né, e eu falava não educação e tal, mas a questão é que sempre vou ter jeito pra coisa, assim modéstia a parte sempre levei jeito pra coisa, e... Acabei me envolvendo aqui na EB tomando gosto, ai eu falei não... Então eu vou fazer e... É mais uma opção se caso eu desistir realmente da vida acadêmica como pesquisador e tal (risos) que eu ainda nem provei né de verdade, que ainda pretendo andar por este terreno, mas o fato que estou muito envolvido com isso.

Turno 13: [Entrevistador]: E qual era da Biologia que você mais gosta?

Turno 14: [Mediador V2]: Eu gosto muito de zoo e eco, acho que são os dois assim mais... Que mais chama minha atenção.

Turno 15: [Entrevistador]: E na Estação Biologia você está desde quando? 
Turno 16: [Mediador V2]: Desde que eu entrei na bio também, desde o dia do primeiro semestre de 2010, só que no primeiro semestre de 2010 eu fui meio várzea assim (risos)... Eu não aparecia muito, eu não levava muito a sério, mas ai no segundo eu comecei levar mais a sério a EB e daí eu mergulhei de cabeça, inclusive quando eu entrei aqui e... Foi muito assim porque ah... Porque foi um bando de bicho do meu ano também né entrando ai vamos lá conhecer vai ter uma apresentação lá, e eu fui meio que no comboio, tanto é que eu falei assim né eu não tinha intenção de trabalhar com educação, ai eu falei: "Ah eu vou". Ai eu gostei e tal, mas não levei muito a sério assim de cara só que depois comecei a pegar gosto pela coisa e... Já no segundo semestre me identifiquei assim de cabeça.

Turno 17: [Entrevistador]: Legal. E como é que foi seu treinamento? Você teve o treinamento?

Turno 18: [Mediador V2]: Tive. Nossa faz tanto tempo, mas fiz, fiz sim. Foi o pessoal 09 que aplicou o treinamento a gente fez, não lembro quanto tempo exatamente ele durou, mas, deve ter... Eu acho que durou também uma semana, faltei em algumas coisas como disse não estava levando muito a serio quando eu entrei (risos) faltei em algumas coisas, mas eu lembro de ter feito algumas atividades assim...e...era bem interessante assim.

Turno 19: [Entrevistador]: Era Comissão de Visita quando você entrou?

Turno 20: [Mediador V2]: Quando eu entrei era CV (Comissão de Visita).

Turno 21: [Entrevistador]: Tá. Em relação a essa sua mudança de postura, o que você acha que mais te motivou a... Começar a gostar?

Turno 22: [Mediador V2]: O que mais me motivou, eu acho que foi a atuação prática, quando eventualmente tinha uma visita e deste o início que quando você entra você já pode participar de visitas. Eu acho que foi a prática que falou "nossa gente isso é fantástico, sabe?" De você... Vivenciar... A experiência de ser monitor, de ensinar alguma coisa, passar alguma coisa. Acho que foi a atuação em si como monitor embora inexperiente total, isso foi que mudou assim, não o negócio é legal sabe? Vale a pena... Investir assim levar a sério.

Turno 23: [Entrevistador]: Quantas visitas assim... Quantas você... Vai ser difícil e... Qual foi a experiência mais marcante pra você na EB até agora?

Turno 24: [Mediador V2]: Mais marcante... Olha... Em questão de visita né? Você quer disser na atuação assim?

Turno 25: [Entrevistador]: Isso. 
Turno 26: [Mediador V2]: Olha uma bem marcante pra mim que foi a da... Visita Fundação Casa, que é a antiga FEBEM, né? Que foi uma coisa assim pra mim total quebra de paradigma, porque... Na primeira vez que a gente recebeu... Antes a gente, nossa como a gente vai fazer e tal, não sei o quê. Querendo ou não rola um pouco de preconceito isso aqui, tem que ser totalmente diferente não... Às vezes não tem que ser tão diferente assim sabe? E... Eu acho que foi muito marcante assim, até mesmo porque eles tiveram uma resposta, eles nos deram uma resposta que eu não esperava, eles foram superatenciosos, alunos que vieram no começo um pouco tímido, mas depois se soltaram, curiosos e bem participativos, eu... Fiquei surpreso. Essa foi uma experiência muito marcante e... Acho que outra (risos) de um colégio que uma vez veio por uma agência de turismo e meu, tinha uns 70 alunos, houve que marcaram meio que errado, eu liguei pro cara e falei 77 alunos, e dai lhe dar com monte de criança(risos)de uma vez, foi bem complicado, então foi marcante assim.

Turno 27: [Entrevistador]: E era de Ensino Fundamental?

Turno 28: [Mediador V2]: Era de Ensino Fundamental principalmente.

Turno 29: [Entrevistador]: Nossa! (risos) É... Antes de você entrar na USP você trabalhou com alguma coisa?

Pausa para atender o telefone.

Turno 30: [Entrevistador]: E... Antes de você entrar na USP, você já trabalhou com alguma coisa? Como voluntário?

Turno 31: [Mediador V2]: Hum... Olha nessa área assim da educação... Não... Na verdade acho que nada com nada, assim com o voluntário, acho que tenho aqui mesmo o primeiro contato...

Turno 32: [Entrevistador]: E sem ser na educação?

Turno 33: [Mediador V2]: Olha pra não falar que eu nunca trabalhei com nada, houve uma época em quando eu estava no Ensino Fundamental II ainda, eu ia de escola, eu ia de perua para a escola né. O tal daquelas topiques assim. Então eu comecei a trabalhar com a mulher_ de pegar as crianças, cuidar e entregar em casa então ela pegava desde o prezinho até a minha séria que era a oitava séria assim.

Turno 34: [Entrevistador]: Aham.

Turno 35: [Mediador V2]: E daí foi o primeiro contato que eu tive de ser meio que o tio das crianças sabe pô! Algo assim foi o único contato que eu tive antes de entrar na... Na USP. 
Turno 36: [Entrevistador]: Legal! E antes de entrar na EB também, não você falou que entrou na faculdade já entrou na Estação Biologia né? E você me disse que o que te motivou foi seguir outros bichos...

Turno 37: [Mediador V2]: A princípio para entrar sim. Foi muito... Vi os outros indo "ah vamos lá? Vamos".

Turno 38: [Entrevistador]: Pra entrar e pra continuar foi a questão da prática?

Turno 39: [Mediador V2]: Da questão da prática, atuação.

Turno 40: [Entrevistador]: Tá. E... Eu sei que vocês não tem uma função definida aqui na EB, mas assim... Você tem né? Qual é a sua função na Estação Biologia?

Turno 41: [Mediador V2]: (risos) Olha eu não sei... É... Assim... Função definida eu não tenho, eu tenho, por exemplo, como posso dizer um... Um edital assim das funções de cada, de cada monitor, mas acontece que... Isso conversando com os que eram monitores antigos, por exemplo, como mediador V1 que é desde 2009 é uma coisa que aparece que acontece naturalmente existem algumas que acabam que se envolvendo mais e... Meio que acontece essa coisa de algumas responsabilidades caírem pra ele, atualmente assim... Eu diria que minha função assim aqui com o que eu mais trabalho além das práticas nas visitas e tal, é da bastante da parte burocrática assim é... Conversa com o pessoal da administração, é... A organização dos monitores pra tocar uma reunião, pra saber o que prioridade a gente discutir, é...outra coisa também que envolve muito ai, acho que também até pela questão de eu ser representante discente da CCEX, qualquer evento de extensão que a CCEX faça, é impressionante como eles querem a participação do pessoal da EB dando monitoria ou seja na feira de profissões lá no Novos talentos, lá no pessoal, tudo bem novos talentos não é da CCEX mas deve ser da CCEX da Física né? E... Sei lá o pessoal do CIENTEC então acaba que gostam bastante da participação dos monitores da EB e não sei por eu está em contato com eles lá e aqui, acaba que eu faço a ponte, eu que organizo os monitores, "oh vamos nos comportar assim, vamos levar tais atividades, fazer de tal forma... E (risos) eles até brincam as vezes eles falam você não é presidente da EB e não tem isso aqui de verdade, verdade não tem uma divisão de cargos, mas acontece de um se envolverem mais.

Turno 42: [Entrevistador]: Você se identifica como... Entre aspa, o Centro da EB nesse momento?

Turno 43: [Mediador V2]: Sim.

Turno 44: [Entrevistador]: Se identifica? 
Turno 45: [Mediador V2]: Me identifico.

Turno 46: [Entrevistador]: Tá. E você como esse Centro da Estação Biologia, como é cuidar do treinamento dos bichos? O que vocês passam nessa... Qual é a preocupações de vocês de passar, o que vocês passam pros bichos nessa semana de treinamento?

Turno 47: [Mediador V2]: Tá. Ó quanto ao treinamento é uma coisa muito assim, a gente tem preocupação que faça parte do treinamento que você treine outros monitores, então o ano que acabou de entrar, por exemplo, 2012 obrigatoriamente eles vão treinar 2013, a gente deixa o treinamento na mão deles. Obviamente a gente ajuda, com qualquer dúvida, qualquer problema a gente esta lá pra dar opinião, sugestão, fala como foi no passado, como pode ser, mas a gente gosta de deixar na mão deles assim...

Turno 48: [Entrevistador]: Os que eram bicho vão... Treinar os bichos atuais?

Turno 49: [Mediador V2]: Até por uma questão de continuidade, assim de que, porque a atuação de um monitor aqui ela é... Eu diria que é efêmera né? E... Eu acho que isso é uma coisa do universitário participar dos projetos é uma coisa que acaba sendo efêmera, não dá pra durar tanto tempo assim. É um ou outro que tipo Peralta que consegue ficar 4 anos, outro 3 e algo assim. Então por essa questão da continuidade a gente faz sempre fez questão disso e pela experiência de você... Sei lá se você vai ficar um ano na EB você ter a experiência de treinar uma outra pessoa, então eu diria que nesse sentido assim não sou eu por exemplo que centraliza de ensinar o treinamento, vai ser assim, assim assado. Obviamente a gente acaba conduzindo não só eu como os outros monitores mais antigos, mas a gente deixa na mão assim a organização, de entrar em contato com os bichos, bolar uma grade de atividades que vão ser feitas durante o longo da semana de treinamento, de qualquer coisa assim dessa natureza deixa na mão deles.

Turno 50: [Entrevistador]: E como é essa questão de passar e... Como vai ser feito. Não porque sei que tem um protocolo pra ser seguido. Como é passar isso pros bichos é... Pra construção da fala, pra interação na visita, pra eles saberem aonde eles vão entrar né? Como eles vão atuar?

Turno 51: [Mediador V2]: Então né! Esse lance de saber, de passar essas coisas, por exemplo, existe um protocolo, cada atividade tem um protocolo escrito e... O intuito disso é que é mais voltado realmente pro bicho que tá entrando, então ele vai apresentar uma atividade, ele tem algo pra ele ler, eu não sei, parece que isso é muito importante no começo, eu pelo menos achava assim quando eu ia apresentar uma coisa nova, eu realmente ia lá no protocolo lia assim, me preocupava com os detalhes e eu acho que todo mundo deve passar 
por isso assim, pelo que escuto deles falando, as vezes, antes da gente começar a visita você vê aquela lidinha rápida assim: " Ah vou ver se não esqueci nada". Mas a gente deixa sempre muito claro que o protocolo é uma receita de bolo que... Do jeito que está escrito ali a chance de dá errado é muito pequena, mas você não tem que necessariamente seguir aquele protocolo. O importante é você passar os conteúdos importantes agora como você vai fazer isso a gente deixa os monitores bem livres assim pra cada adquirir o seu jogo de cintura, a gente enfatiza muito isso, de que eles não precisam ser como robozinho que... Abre na página 32 e vai até a página 37 e cospe aquilo de uma maneira mecânica, não pensada, não interage com a sala, talvez até uma piada, que vem fazer. Uma piada que ele leu no protocolo (risos) entendeu? A gente enfatiza muito isso, deles se soltarem, de eles terem o próprio jogo de cintura, de criarem sua própria linha de raciocínio desde que passe o conteúdo que tem que ser passado. Então não necessariamente tem que seguir as ordens $\mathrm{ABCDE}$, mas se fizer sentindo do jeito que você passar BCADE passa também dá certo e a gente vai notando que isso acontece só com o tempo assim, a atuação no começo todos os bichos você vê que... Eles sabem o protocolo assim, se você for acompanhar a leitura do protocolo é exatamente aquilo que eles estão fazendo e eu acho que com o tempo ganhando o... Sei lá a confiança, a experiência e tal eles começam a inovar mais e... Acontece naturalmente assim e a gente sempre dando com força mais positiva eu diria assim: "Não... Mandaram muito bem e tal, não sei o quê", corrige talvez algumas coisinhas "Olha você esqueceu disso ou essa parte você podia ter feito assim", mas como sugestão, nada cobrando.

Turno 52: [Entrevistador]: Então! E no caso você, tenta pensar e lembrar um pouquinho como foi a sua... A construção da sua fala? Na sua visita, lá que você tá lá na frente. Como é que você construiu essa fala?

Turno 53: [Mediador V2]: Tá! A princípio é... Quando a gente apresenta uma primeira vez, eu já tinha muitas atividades, já vi os monitores apresentando né? Antes. Então... Eu prestava atenção neles apresentando, eventualmente dependo da atividade no meio de uma visita que eu participei é... Um monitor virou e "falou vai agora tenta ai apresentar". Ai você tenta dá, às vezes dá aquela gaguejada né enfim. Mas assim pessoalmente eu nunca tive muito problema pra falar em público então... Esse problema pelo menos eu não passei, mas obviamente eu tive muitos ganhos na questão de elaborar uma linha de raciocínio e a minha construção assim no começo eu usava protocolo, lia o protocolo e... Eu acho que antes de vir pra EB eu vinha vindo no caminho de casa assim pensando "ah eu vou falar sobre isso" e ficava pensando como se eu estivesse explicando pra alguém, pra uma única pessoa. Eu pensava assim "ah se 
eu fosse explicar isso pra alguém como faria". Então ficava na minha mente que nem que martelando aquilo cerca de uma hora antes da visita pensando ah vou fazer assim assado, falo isso ai chegava aqui eu fazia, acho que eu... Não sei é difícil pensar de como se constrói isso ao longo do tempo.

Turno 54: [Entrevistador]: Você acha que você foi influenciado por algum... Monitor antigo tipo...?

Turno 55: [Mediado V2]: Sim.

Turno 56: [Entrevistador]: Sabe me citar algum assim ah eu gostava do jeito que ele falava ou...

Turno 57: [Mediador V2]: Olha eu gostava muito do... Fui influenciado muito pelo Peralta isso sem dúvida, agora quanto ao jeito de... De falar da apresentação em si... Ah, tinha um monitor que me chamava bastante atenção era Júlio também 09, eu gostava muito da apresentação dele, achava impecável assim, ele tocava em todos os pontos, ele era muito claro e eu acho que me inspirei bastante nele assim, na questão de... Eu gostaria de ser tão claro quando ele durante uma apresentação... Agora tinha uma coisa assim que ele não tinha muito ai eu acho que eu tinha necessidade de colocar é a questão da... Como posso dizer... Da desinibição assim, eu não gosto de uma coisa muito sisuda sabe? Uma apresentação sisuda, tipo séria então eu gosto sei lá, às vezes solto uma piada no meio... Eu gosto de provocar o riso, provocar eu acho que é mais gostoso aprender assim. E durante a apresentação eu tenho um retorno assim que eu percebo que quando um aluno ele se diverte com aquilo ele tende a prestar mais atenção, obviamente bem dosado né? Você não vai também ser um comediante (risos) lá na frente, um palhaço porque dai vira farra e ninguém leva a sério, mas eu acho que assim em certos momentos assim se você dosar um pouco de humor de, de sei lá de diversão ajuda bastante, isso eu acho que ele, por exemplo, não tinha muito, ele sabia muito bem, talvez isso, então isso foi uma coisa que eu incorporei assim, não isso eu acho que é uma coisa que tem que ter, mas eu me espelhei muito nele na questão da clareza, do jeito de apresentar, eu falei "nossa quero ser tão claro quanto ele" porque eu via que o pessoal entendia mesmo assim quando ele falava.

Turno 58: [Entrevistador]: Legal! E o conteúdo da tua fala vinha só do protocolo?

Turno 59: [Mediador V2]: Não. Não vinha só do protocolo, no... Nas primeiras é... O protocolo na verdade eu nunca li muito assim, só li cada atividade mais de três vezes foi muito, mas era uma coisa assim a primeira vez eu li o protocolo e dai sei lá na noite anterior da visita eu dava uma olhada na internet pra ver se eu achava alguma coisa, por uma questão 
assim, é eu notei isso acho que até hoje é muito claro surgem coisas que não estão no protocolo, sempre, na visita. Você está interagindo com pessoas, as pessoas pensam, elas não são (risos)... Elas fazem umas perguntas assim, que deixa você assim: "gente! Nem tinha pensado nisso.” E dai sempre antes de uma atividade, por exemplo, de apresentar sei lá... Fisiologia da visão a primeira vez, a segunda vez que apresentei eu lembro deu sentar em frente do computador sei lá, não precisava ir muito longe assim, Wikipédia mesmo "ou deixa eu dar uma lida assim ver o que tem", às vezes, aparece uma curiosidade alguma coisa assim que é interessante você falar e que o pessoal curtir né? Querendo ou não eles te escutam um pouco assim dá... Momento Discovery sabe?

Turno 60: [Entrevistador]: Claro, verdade. Deixa eu ver que mais... Então assim qual a atividade que você mais gosta da Estação Biologia?

Turno 61: [Mediador V2]: Ahm... Olha eu acho que... Nossa (risos)...é um pouco difícil. Eu poderia citar 3 assim que eu gosto muito. Eu gosto muito de apresentar Biodiversidade, Fisiologia e pra crianças assim as de interação. É mas dessas assim que eu mais gosto mesmo de apresentar... Eu acho que ficaria com Fisiologia. Apesar de eu gostar muito de zoo, por exemplo, (risos) como eu já disse e Ecologia, porque eu acho que a... As atividades assim uma que o público interage muito assim, é interessante ver como desperta a curiosidade neles, eu não sei por ser uma questão assim talvez antropocêntrica sabe? Por ser atividade focal, dar enfoque ao ser humano como: os órgãos do sentido e tal e daí despertar a curiosidade. "Ah, mas e nesse caso o que acontece, e se sou míope, se sou sei lá, se eu tenho problema de surdez ou de equilíbrio ou coisa assim?” É interessante assim... Uma visita de fisiologia se você der corda você perde horário assim, porque eles vão levantando a pergunta assim, eu gosto muito disso, eu acho isso muito legal, acho que é por isso é a área que eu mais gosto de apresentar. Agora Biodiversidades também não fica atrás nesse quesito, na hora que está com os bichos lá mostrando, meu...por exemplo, o bicho-pau, é uma pergunta atrás da outra assim, é um negócio muito diferente assim, tem gente que nunca viu, nunca sabia que existia um inseto tão diferente, desse tamanho, dai as perguntas vão vindos assim, isso é muito gostoso. Eu acho que é por isso são as que mais gosto.

Turno 62: [Entrevistador]: E qual público que você prefere?

Turno 63: [Mediador V2]: Eu prefiro os maiores. Então assim, é... Ensino Médio e Ensino Fundamental assim II (risos)... Eu prefiro os maiores é... Eu acho que sei lá eu julgo assim que eles têm maior facilidade de entender, ai às vezes até me questiono, será que não é uma deficiência minha não saber passar pros menores ou algo assim. É... E eu acho que por eles 
serem mais velhos me permite fazer aquilo que falei que eu gosto de ter tom da brincadeira, o tom da diversão, eu não sei muito bem como aplicar isso com crianças assim, entendeu? E com muitos muito novinhos. E acho que até é uma questão (risos)... Não tenho paciência com os catatauzinhos, mas tem monitor, por exemplo, que adora sabe? Prefere mil vezes numa visita pra fazer abelhudo com criancinhas que às vezes usa chupeta, sabe, do que os mais velhos assim. Eu não sei eu gosto dos mais velhos eu acho que... Nunca tive problemas com eles.

Turno 64: [Entrevistador]: Qual você acha que o objetivo da Estação Biologia?

Turno 65: [Mediador V2]: Hum...essa é uma boa pergunta, por muito tempo eu achava que o objetivo da Estação Biologia era principalmente receber visitas e fazer extensão é...passar conteúdo, mas hoje eu acho que o principal pra mim que eu considero mais importante é formar monitores.

Turno 66: [Entrevistador]: Por quê?

Turno 67: [Mediador V2]: Mas do que você faça isso, por quê? Porque eu acho que é uma coisa assim, aqui é o que você mais faz, entendeu? É a visita é uma coisa muito pontual você passar aquele conhecimento no dia da visita, é uma coisa que você tem três horas, é um momento que você tem com aquela turma de três horas é... Depois você não tem mais contanto a menos que eles retornem aqui, então você não sabe o quão foi o efetivo... A gente tem alguns parâmetros assim, pelo questionário que eles respondem e tal, mas, eu acho que é muito pontual nossa atuação, agora o que... Porque eu acho mais importante a questão da formação do monitor é pela bagagem que a gente sai daqui. Todos os monitores que eu conheço assim, não todos, mas grande parte dos monitores que fizeram aqui Estação Biologia, que foram monitores daqui, tiveram preferência sabe? Pra ser monitor é... No Museu Biológico, no Catavento é... Em monitorias de matérias e monitoria de outros projetos de educação ambiental, eu comecei a perceber o quanto conta isso no currículo assim, e não é só uma coisa assim porque dá no currículo "ah Estação Biologia de Instituto de Biociências da USP" eu acho que pela questão do talvez do examinador, do coordenador de perceber e falar "nossa você tem jeito assim pra coisa" e...é muito legal vê isso assim...acho que nosso ano a gente não percebe quando você entra, o seu crescimento. Você não percebe o quanto é gradual e acontece, mas com os bichos assim você nota muito isso, eles entram às vezes completamente perdidos e você vai vendo que o cara vai tomando uma postura de monitor assim, você fala "meu esse menino é um monitor olha só", é muito legal, então eu acho que é por isso que é a principal função assim, atualmente é a formação de monitor. 
Turno 68: [Entrevistador]: Legal. E... É... Quais são os pontos fortes e os pontos fracos que você enxerga na Estação Biologia?

Turno 69: [Mediador V2]: Os pontos fortes eu diria que... A gente tem uma liberdade muito grande aqui os monitores no gerenciamento da Estação Biologia, embora tem a professora Beatriz seja nossa coordenadora, a professora Alessandra também ela co-coordena junto com a professora Beatriz. Eu acho que ambas, deixam a gente bem à vontade, pra colocar nossas ideias, pra pensar no que fazer, elas não interferem assim megalomaniacamente "ah não vocês vão fazer assim assado" essa burocracia assim assado é... A atividade tem que ser assim assado, eu acho que elas dão muita liberdade, o instituto inclusive dá muita respaldo pra gente nesse sentido, então a gente... Sei lá, a gente pode pegar o telefone aqui ligar lá embaixo "oh estou precisando disso, pra tal atividade tem como vocês conseguirem", eles vão atrás às vezes eles nem questionam assim é... sabe? Pra que atividade que é, ah mais o professor X Y W, tão cientes disso não sei o que. Eu gosto muito disso aqui, eles dão bastante liberdade assim pra gente funcionar do jeito que a gente funciona, só que um ponto fraco, talvez esteja também talvez nessa liberdade assim não sei, isso é uma coisa muito minha assim filosofia é... Às vezes a gente tem tanta liberdade que a gente quer abraçar o mundo, às vezes acontece muito isso assim, surge um projeto a gente "não, vamos pegar, vamos tocar, não sei o que, não sei o que". No final, tudo a gente quer se envolver, tudo a gente quer se enfiar. E daí chega o momento assim que o pessoal nossa tá rolando muita coisa, então eu acho que essa é uma fraqueza que a, por conta dessa liberdade talvez a gente tende a querer abraçar o mundo, a querer se enfiar em tudo e as vezes não fazendo sendo assim, sei lá $50 \%$ das coisas que a gente se propõe a fazer, então acho que isso é ruim assim, nesse ponto.

Turno 70: [Entrevistador]: Legal. É você enxergar a Estação Biologia como espaço de Educação Não Formal, por quê?

Turno 71: [Mediador V2]: Hum... Olha... Assim até hoje, eu passei por várias concepções assim do que é um espaço de educação formal e não formal. Mas... Eu enxergo. Acho que posso dizer que enxergo, até mesmo porque entendo como espaço de educação formal é... Uma escola, obviamente, sala de aula, enxergo inclusive ai não sei se é concepção errada minha, por exemplo, o museu, eu acho que é um espaço de educação que pode se dizer formal, pelo fato dele existir a muito tempo esse negócio de museu e tal, a questão é pode estabelecer ou não considerado formal por uma questão de hábito, as pessoas não tem também tanto hábito de ir ao museu, os professores não sei se tem tanto hábito de levar seus alunos ao museu, a escola pública por exemplo, converso com os professores é bem difícil eles 
conseguirem, embora os professores tenham vontade de levar o aluno no museu por exemplo, é bem difícil ele conseguir respaldo da escola pra isso, o pessoal meio que barra muito e a EB eu considero então um espaço de Educação Não Formal, porque não acho que ela se enquadra no perfil de sala de aula, não acho que ela se enquadra no museu embora tenha elementos que lembre o museu, a gente por exemplo não tem um acervo, não tem um curador do acervo, coisas que são essenciais no museu além disso...o museu que eu saiba também lugar de pesquisa né? Por exemplo, o museu de zoologia, que aqui não acontece uma pesquisa com dados do nosso acervo e... Eu considero que é um espaço de educação informal pela natureza das nossas atividades, era uma coisa assim muito... Parece que surge espontaneamente assim, uma ideia, o monitor tem uma ideia, vou bolar tal atividade, ele bola, dai eventualmente uma escola liga ah você oferece às vezes a atividade "oh tem uma atividade que trata desse assunto, parece ser adequada pra essa turma e tal", surge o interesse, o professor topa, ele vem, e a gente faz. Eu acho isso muito informal. Eu acho que não tem nada formal, não tem assim um... Ah não essa atividade sensacional foi criada pelo doutor fulano de tal e não sei o que, está no nosso site e... Mais de ser informal ainda porque tem muitos professores que ligam às vezes marcando uma visita e fala assim "ah então eu vi que vocês tem atividade tal $\mathrm{XY}$ e blá blá blá, mas eu queria uma atividade XY só que eu queria que vocês dessem enfoque...de tal assunto". Por exemplo, "ah eu vi que vocês atividade de fisiologia, mas queria que vocês dessem enfoque bastante evolutivo nela, tem como?" A gente fala "tem". Ai senta os monitores pensa, vamos mudar isso e tal pra gente é... Bastante plástico né? Eu diria. Então a gente consegue se moldar bastante por isso que acredito que é um espaço bastante informal. Não é nada dentro de caixinhas assim, sabe? É imutável, acho que a gente é bastante mutável. Até atividade nova já aconteceu, professor ligar "Ou queria uma atividade botânica com ênfase ei lá em flores tem como vocês fazerem? A gente tem, ai vai atrás e se vira e faz uma atividade que as vezes você nunca vê na história da EB mas acontece, por isso que acho que é informal.

Turno 72: [Entrevistador]: Você gosta da parte da elaboração da atividade? Você participa?

Turno 73: [Mediador V2]: Já participei mais. Atualmente não tenho participado tanto, mas eu já participei mais. Mas era muito interessante assim porque as vezes parece ser muito simples nas atividades você vê ela pronta fala nossa que ideia simples...você chega até achar genial (simples, barato não usa muita coisa e é genial) mas quando você para pra pensar na elaboração relativa, você vê que não é simples de fazer, pode até ser simples a ideia genial mais ela não é simples de aparecer assim, ai você começa a entrar em conflito assim de pontos 
tocar, de que...sabe? De como proceder, mas é interessante, eu gostei bastante assim de participar, já tive oportunidade de participar de elaboração de algumas atividades e é bem legal. É que atualmente não estou mais tanto nisso.

Turno 74: [Entrevistador]: Você não gosta ou por conta de você está mexendo com outras coisas?

Turno 75: [Mediador V2]:Obviamente por estar mexendo com outras coisas.

Turno 76: [Entrevistador]: Tá. É... Em relação a você o que você enxerga de ponto forte em você, que você acha que auxilia aqui na Estação Biologia?

Turno 77: [Mediador V2]: Hum... Olha acho que isso inclusive foi feito uma pergunta similar quando entrei como bolsista, que os outros bolsista de entrevistam né? Me perguntaram algo assim. É eu diria que assim modéstia parte eu tenho uma habilidade que eu acredito ser bastante forte de falar em público e eu acho que isso ajudou muito assim é... Passar pros outros monitores os objetivos da Estação Biologia, o treinamento pros meus bichos acho que contribui bastante nesse sentido, acho que a eloquência assim com que eu tenho, eles se identificaram bastante, então eles conseguiram pegar bastante coisa, eu sou uma pessoa que me considero bastante organizado com relações em... Sei lá com a burocracia, por exemplo, assim, então eu acho que por isso eu acabei centralizando tanta coisa assim, porque eu me considero bastante organizado e assim eu gosto muito do envolvimento com o público, isso é uma coisa que sempre gostei, sempre gostei de conversar, de falar, de... Sempre fui muito expressivo. Então acho que assim foi, talvez de longe a principal característica assim que contribuiu pra que eu me desse tão bem aqui na Estação Biologia. Por exemplo, é questão de falar em público, de interagir eu sempre gostei desse contato é... E é uma coisa que acontece muito aqui, que é essencial pro monitor que é essencial pra quem tá na burocracia cuidando... De contatos externos é acho que é essencial então acho que essa é principal característica.

Turno 78: [Entrevistador]: E... Pretende continuar sendo monitor? Sei lá sair da Estação Biologia pra outro museu ou continuar na área da educação?

Turno 79: [Mediador V2]: Então... Eu estou no momento da vida que estou pensando muito nisso, como te disse eu nunca tive oportunidade de experimentar a área acadêmica de verdade assim, não que eu nunca tive oportunidade, mas nunca quis assim, não achei que era o momento. Aí eu sempre fiquei pensando assim, ainda mais nesse momento agora né? Eu tô pensando. Acho que está na hora de eu procurar um laboratório, vê se realmente eu não gosto de fazer pesquisa, se eu gosto ou não. Ai eu tinha a pretensão de o ano que vem por exemplo já no primeiro semestre ir atrás disso, mas não tenho pretensão de sair da EB, pretendo 
continuar ano que vem certeza que continuo inteiro, e olha só o que aconteceu, nesses dois ultimas semanas saiu um estágio publicaram ai na no facebook aqui na bio a mobiliss que é o nome da fazendo processo de seleção pra estagiário como auxiliar de professor do Ensino Fundamental II, ai eu olhei e falei "eu acho que vou tentar" e ai acabou que o pessoal ficou sabendo, meu você podia tentar, tem mó perfil não sei o que, ai falei que saber eu vou tentar também não adianta eu lutar tanto contra assim, as coisas que eu aparentemente tenho vocação, dai eu mandei eles vão fazer uma entrevista comigo amanhã, então eu não sei que fim isso vai levar, mas mesmo que eu entre lá eu pretendo continuar como monitor aqui, agora monitoria em outro lugar eu ainda não pensei assim, não cogitei, mas também não... Não descarto essa possibilidade não, por exemplo, tem um projeto que chama Trilhasubi acho que você já tenha ouvido falar, que é daqui do EB professor Flávio da Botânica, é um projeto de educação ambiental muito legal que existe há 10 anos já e acontece... Em regiões costeiras então, por exemplo, acontece no sirimara, acontece lá no Zé Anchieta e ano passado eu fiz a disciplina né? De formação desses monitores e esse ano já me inscrevi de novo porque eu quero nas férias ficar dando monitoria lá, então eu gosto. (Risos).

Turno 80: [Entrevistador]: É... Você já falou que na EB pode ajudar na formação profissional, você falou bastante do objetivo inclusive, ficou legal. É... Como você se vê na Estação Biologia daqui a seis meses?

Turno 81: [Mediador V2]: Daqui a 6 meses...Ah... Daqui a seis meses, pretendo não ser mais bolsista, porque já terei sido bolsista quase 3 anos (risos) e assim como eu disse essas coisas que os universitários se envolvem durante a graduação acaba sendo efêmero, eu acho 3 anos muito pouco, eu acho bastante pouco e assim sabe? Eu tenho que ver o que eu vou fazer da minha vida, porque sei que não vou poder ser monitor da Estação Biologia pelo resto da minha vida então eu pretendo assim deixar de ser bolsista, mas continuar como voluntário seja atuando em visita, o Peralta fala muito isso sendo um monitor sênior né? Dando conselho, ajudando no que for possível, mais deixando de fazer algumas coisas que requer mais energia, que requer mais envolvimento e que até mesmo pelo fato ser você ser um bolsista você se envolve mais, então eu acho que assim, o fato de eu deixar de ser bolsista já vai aliviar bastante coisa assim desse comprometimento né? Embora ainda continuaria comprometido como voluntário e tal certas coisas obviamente vai ser mais função dos bolsistas, acho que você ganha pra isso então.

Turno 82: [Entrevistador]: Ai o centro deixaria de ser você? 
Turno 83: [Mediador V2]: Deixaria de ser eu, exatamente. Isso é uma coisa que eu percebo assim é uma coisa cíclica aqui na EB conversando com os veteranos, com os mais antigos antes de mim era o mediador V1, por exemplo, quando eu entrei ele era o centro tudo girava muito em torno dele e conversando com ele também acho que chegamos a uma conclusão acontece naturalmente assim, alguém parece que leva mais jeito e vai, antes dele era a N. que é nossa monitora girava muito ao redor dela e assim vai indo, então acho que chegou uma hora tem que ir mudar porque se não, você não passa pra frente a ideia e é muito importante aquilo que eu falei no começo do treinamento não só na atuação como monitor lá na frente fazendo atividade, mas o gerenciamento então é importante que uma nova pessoa se envolva nisso ou mais de uma pessoa nova se envolva nisso entendeu e tome ciência de como cuidar, de como se virar pra essas coisas assim.

Turno 84: [Entrevistador]: E já tem alguém em vista, isso é por votação ou a pessoa fala eu quero ser?

Turno 85: [Mediador]: Então é uma coisa muito assim, por exemplo, tenho pessoas em vista sim que acho que tem potencial pra virar o centro e é muito informal assim, você chega na pessoa e "olha tá a fim de... Como a gente fala: de pegar essa p... (risos). De olha eu acho que tu leva jeito e tal e acontece". Eu acho que não é por votação, não é assim alguém que vira e fala eu quero, pelo menos nunca aconteceu, olha eu gostaria de me inteirar mais nisso e tal, eu acho que acontece naturalmente é... Quando a gente tá trabalhando a gente percebe que tem algumas pessoas que destacam também, nossa essa pessoa tem muito perfil assim pra firmar um esquema dá um role assim, vai dar certo. Daí normalmente você chega e fala "e ai?". Foi, por exemplo, que aconteceu comigo assim com o mediador V1. Tipo, ele percebeu que eu levava jeito pra coisa dai meio que sempre foi aconteceu achando tá a fim de me ajudar nisso que eu tô fazendo eu ia lá e ajudava, a tá a fim de me ajudar nisso e quando você vai ver você está envolvido e acho que sempre aconteceu assim e é o que estou fazendo agora com o mediador C (risos). Tipo me ajuda nisso não sei o que, e eu acho que tenho esse potencial pra firmar isso também. É muito informal.

Turno 86: [Entrevistador]: Legal. Quer acrescentar mais alguma coisa?

Turno 87: [Mediador V2]: Olha não sei (risos), acho que já falei tanto, nossa nem sei mais o que acrescentar assim, assim acho que está de bom tamanho.

Turno 88: [Entrevistador]: Tá bom, muito obrigada.

Turno 89: [Mediador V2]: Ah de nada. 
São Paulo, 18 de Maio de 2012.

\section{$1^{\text {a }}$ Entrevista com mediador Novato 1 (N1) da Estação Biologia.}

Turno 1: [Entrevistador]: Entrevista dia 18 de maio com o mediador N1. Mediador N1, quantos anos você tem?

Turno 2: [Mediador N1]: 21

Turno 3: [Entrevistador]: Quanto tempo você tá na biologia?

Turno 4: [Mediador N1]: Eu entrei esse ano.

Turno 5: [Entrevistador]: Por que você escolheu fazer biologia?

Turno 6: [Mediador N1]: Primeiramente, porque eu adoro a área da zoologia e também tive professores muito especiais, assim, de biologia. Tanto que eu queria dar aula também. Me inspirou muito ter professores assim. Por isso que eu estou na EB também para aprender didática.

Turno 7: [Entrevistador]: E por que você escolheu fazer biologia na USP?

Turno 8: [Mediador N1]: Ah, porque é a melhor estrutura né. E também não tenho condições para pagar uma faculdade, então a única solução é uma pública mesmo.

Turno 9: [Entrevistador]: E você vai escolher entre licenciatura e bacharelado ou vai fazer os dois?

Turno 10: [Mediador N1]: Vou fazer os dois. Eu quero ser os dois ao mesmo tempo (risos).

Turno 11: [Entrevistador]: Mas qual a sua preferência a licenciatura ou o bacharelado para atuar profissionalmente, você vai querer ficar na pesquisa ou na área de ensino?

Turno 12: [Mediador N1]: Hum.. Pesquisa, pesquisa. Mas eu não tenho bloqueios para ser professor.

Turno 13: [Entrevistador]: E qual área da biologia que mais te interessa?

Turno 14: [Mediador N1]: Zoologia.

Turno 15: [Entrevistador]: Trabalha ou já trabalhou em alguma coisa antes de entrar aqui na USP?

Turno 16: [Mediador N1]: Sim, já trabalhei como boy interno em uma empresa durante um ano e depois no ano seguinte trabalhei no departamento médico científico como menor aprendiz, na mesma empresa farmacêutica. E atualmente eu sou autônomo, pinto em camisetas. 
Turno 17: [Entrevistador]: Legal!

Turno 18: [Mediador N1]: É assim que eu me viro (risos).

Turno 19: [Entrevistador]: E, então você tá na EB há pouco tempo, também ne?! Alguns meses. Por que você decidiu entrar na Estação Biologia?

Turno 20: [Mediador N1]: É, então. Primeiramente pra aprender a didática pra passar o conhecimento. Eu vejo pessoas que tem um conhecimento muito grande e não sabem repassar isso. E, também, pra eu entrar em alguma entidade da biologia, que não seja só as aulas ne. Eu queria fazer algum projeto fora das aulas. E, também, aprender a falar em público que é bem essencial e, às vezes eu tenho um bloqueio pra isso.

Turno 21: [Entrevistador]: Qual é a sua função lá na Estação Biologia? Você tem uma função específica ou... O que você fez até agora?

Turno 22: [Mediador N1]: Então, nas visitas eu tava controlando o tempo, pelo menos a última eu controlei o tempo em si. Só que pra projetos, por exemplo, eu tô me focando, juntamente com a... Ai eu não sei o nome dela, sei que é o mediador $\mathrm{N} 2$ o apelido dele... A gente tá fazendo um projeto pra poder passar o ensino de cantos de aves pra crianças. Estamos tentando fazer algum projeto assim, com teatro, fantoches. Ainda tá nebulosa a ideia, mas tá surgindo. E eu e outra integrante, a gente tá fazendo, montando uma atividade com... Pra ensinar abelhas pra crianças do ensino... Crianças não, pré adolescentes do Ensino Médio ou do Fundamental II. E também, tô no desafio e tá no começo também. E, o resto é tipo, as atividades do dia a dia, a gente vai preenchendo ne. Mas o principal tá sendo esse.

Turno 23: [Entrevistador]: Entendi. Com qual frequência você vai à Estação Biologia?

Turno 24: [Mediador N1]: Toda sexta-feira de manhã.

Turno 25: [Entrevistador]: De quantas visitas você já participou?

Turno 26: [Mediador N1]: Uma só.

Turno 27: [Entrevistador]: Gostou da experiência? O que você achou?

Turno 28: [Mediador N1]: Gostei muito e achei sensacional. Era o que eu esperava mesmo. A interação com as crianças, ver o desenvolvimento delas fora de sala de aula, ne. Sair daquela coisa chata de professor, giz e lousa.

Turno 29: [Entrevistador]: Você participou da visita que teve qual atividade?

Turno 30: [Mediador N1]: Teve escoisos, que fala um pouquinho sobre genética, e a trilha da biodiversidade. 
Turno 31: [Entrevistador]: Ah, então foi pra Ensino Médio, né?

Turno 32: [Mediador N1]: Sim.

Turno 33: [Entrevistador]: E, a sua função, você falou, foi de contar o tempo.

Turno 34: [Mediador N1]: Uhum.

Turno 35: [Entrevistador]: Você que escolheu isso ou alguém sugeriu que você fizesse?

Turno 36: [Mediador N1]: Não, eu que escolhi, porque eu não queria me expor muito. Eu queria só observar mais e essa é uma função que você mais observa e atua menos.

Turno 37: [Entrevistador]: Por que você queria só observar?

Turno 38: [Mediador N1]: Porque eu tô meio inseguro ainda, por eu estar começando agora. Mas mais pra frente eu vou querer fazer outras coisas.

Turno 39: [Entrevistador]: E pra você qual é o objetivo da Estação Biologia?

Turno 40: [Mediador N1]: Da Estação em si?

Turno 41: [Entrevistador]: É.

Turno 42: [Mediador N1]: Essencialmente é repassar tudo aquilo que a gente tem obrigação de repassar para a sociedade, que elas pagam pra gente todo dia. É, eu acho que todo aluno da USP tem que ter essa noção. Você tá aqui não é simplesmente pra você fazer sua carreira e ganhar seu dinheiro. É você repassar isso de alguma forma pra sociedade. Eu tô fazendo biologia não é simplesmente pra ganhar dinheiro, mas sim porque é uma área que eu adoro e eu posso repassar para as pessoas de certa forma. Dinheiro é consequência. Mas eu já me conformei, não serei rico (risos).

Turno 43: [Entrevistador]: Quais, você acha, que são os pontos fortes e fracos da Estação Biologia?

Turno 44: [Mediador N1]: Fortes e fracos... Hum.

Turno 45: [Entrevistador]: Assim, até agora o que você conviveu, o que você acha que é forte e o que você acha que é fraco?

Turno 46: [Mediador N1]: O forte é que a gente pode explorar muito nossa criatividade e o senso de grupo. Eu acho isso muito legal. Porque não tem um líder, ne. São... É bem espalhado, você tem uma liberdade bem grande pra você expor suas ideias. E se você expõe suas ideias você já começa a fazer que nem essas atividades das abelhas. Eu tô começando a fazer e... Por conta própria. Essa autonomia que você ganha. E... Pontos fracos. Eu ainda não achei um ponto ruim (risos). Eu gosto muito. Eu acho legal também que quem entra, vai por 
pura vontade assim, sabe. Não tem essa de ah, vô pra lá pra ganhar dinheiro. Dinheiro, quem sabe, você ganha depois quando sair da Estação Biologia ne. Esse não é meu foco, pelo menos agora. E ponto fraco... Nossa, eu não... Acho que não faço a mínima ideia. Acho que ainda não achei.

Turno 47: [Entrevistador]: E você, qual você acha que é o seu ponto forte, suas qualidades que você acha que ajudaria lá no trabalho da Estação Biologia ou que tá ajudando já?

Turno 48: [Mediador N1]: Minhas qualidades? É, então, eu tenho uma certa facilidade para ensinar. Eu tenho um irmão mais novo que ele tá no Ensino Fundamental também, ai eu ajudo ele. Tem um primo meu também que eu ajudo ele, dá aula de diversas matérias e... Ah, eu gosto de criar. Essa área de criação eu adoro. E, eu tô tentando inserir alguma coisa com desenho lá no meio. Pra poder conciliar, ne o desenho com... Mas eu acho que minha criatividade assim e minha facilidade de lidar com criança.

Turno 49: [Entrevistador]: E você tá gostando dessa área de monitor, você se vê continuando trabalhando nessa área como mediador e talvez até ir pra um museu, alguma coisa assim?

Turno 50: [Mediador N1]: Sim, sim. Bem prazeroso, assim, você ver o conhecimento se construindo ali na criança e ela entender de fato. Não só tentar decorar para uma prova que vai ter, como acontece na escola, assim.

Turno 51: [Entrevistador]: E você acredita, você já falou algumas coisas disso, mas você acredita que a Estação Biologia vai te ajudar na sua formação profissional?

Turno 52: [Mediador N1]: Uhum. Bastante.

Turno 53: [Entrevistador]: Em que?

Turno 54: [Mediador N1]: Pra dar aula. É... Se eu for escrever algum tipo de livro didático, também, pra eu poder passar a linguagem para as crianças, também. Crianças e outros tipos de alunos. Hum... $\mathrm{Na}$ área de pesquisa... Ah, eu não sei! Eu tô aprendendo bastante quando eu pesquiso sobre abelhas, eu tô aprendendo bastante sobre isso. Acho que é uma carga a mais, fora das aulas ne. Basicamente é isso.

Turno 55: [Entrevistador]: Na área, você falou pra dar aula, no caso, seria o que assim pra dar aula? O que você acha que ajudaria?

Turno 56: [Mediador N1]: Adaptar a linguagem. A linguagem e os métodos de como passar o conhecimento. Entendeu?

Turno 57: [Entrevistador]: E... Você já falou que tá participando da elaboração de atividades. Como você se vê na EB daqui a algum tempo? 
Turno 58: [Mediador N1]: Eu me vejo com uma atividade nova. Essas duas ai, quem sabe?! E talvez como um RD, acho que é esse o nome, pessoa que fica, acho que em seis meses não dá pra fazer isso, pessoa que fica como o mediador V1. Que eles ficam tipo o dia inteiro lá. Tipo uma sexta-feira inteira, por exemplo, ne. E... Mais ativo nas visitas, ne. Não só contando o tempo, mas também apresentando alguma coisa mais ativamente. Um conhecimento maior.

Turno 59: [Entrevistador]: Tem alguma coisa que você queira incluir? Falar sobre a EB, sobre você?

Turno 60: [Mediador N1]: Hum... Não (risos). Acho que não.

Turno 61: [Entrevistador]: Então, tá bom. Muito obrigada.

São Paulo, 18 de Maio de 2012.

\section{$1^{\text {a }}$ Entrevista com mediador Novato 2 (N2) da Estação Biologia.}

Turno 1: [Entrevistador]: Mediador N2, quantos anos você tem?

Turno 2: [Mediador N2]: 19.

Turno 3: [Entrevistador]: Por que você escolheu fazer biologia?

Turno 4: [Mediador N2]: Porque, acho que porque eu ficava meio vidrada assim nas minhas aulas de biologia. Acho que eu era daquelas que não... Ah... Eu gostava mais de ir no colégio mais para ficar com meus amigos, pra ficar tipo assim no sol. Meu colégio tinha bastante espaço verde, sabe. Eu gostava por causa da convivência e tal, das aulas eu gostava, mas o que eu gostava de ir mesmo era mais assim só português e biologia, assim, muito, gostava muito da aula de biologia. E ai, eu tive a chance de fazer uma optativa que era tipo uma aula extra à tarde, assim, chamava biologia experimental. E ai, a gente fazia... Dissecava várias coisas. Tipo no começo era bem... Dissecava, sei lá, fígado de boi. Umas coisas assim mais avulsas. E depois, dissecava rã, galinha e um coelho, que era tipo, o melhor de tudo assim. Era o que o pessoal mais gostava que era o final do curso. E ai foi muito legal fazer esse curso pra mim, achei que centrava um pouco nessa coisa mais prática, além do método também. Porque a gente nunca era cobrado nessa coisa mais de método, dai nessa aula a gente tinha uma professora que era bem... Pegava bastante no pé. Ela mandava a gente fazer relatório, fazer desenhos e dai você tinha que escrever todos os itens bonitinhos no desenho, o que você tava vendo, qual que era o corte que você tava fazendo. Ai eu falei, nossa ne, que diferente, tipo, é difícil, mas ao mesmo tempo é um desafio gostoso, porque a gente trabalhou muito, assim. Porque no começo chegava nessa aula em grupos, eu lembro. Ai meu grupo achava que tava 
arrasando, a gente recebia a nota, 4 (risos). A gente nossa! Ai a gente começou a pegar mais... Morder o bambu que chama ne. Enfim, a gente começou a trabalhar mais, mais forte. Eu gostei bastante. Ai eu ia fazer medicina, tipo, eu prestei medicina logo que eu sai do colégio, ai não passei. Ai eu fui pro cursinho, só que eu tava muito em dúvida. Sei lá. Eu sabia que eu gostava muito dessa área. Mas é que eu sempre tive um pé nas humanas. Fiquei muito tempo em dúvida e ai, eu falei, eu acho que eu não quero trabalhar com pacientes. Eu acho que eu quero ir para essa área mais, eu achava que era muito... Eu ia perder toda essa área de estudar ambiente vai. E eu não queria perder isso, porque eu acho muito legal ir pra campo. Gosto muito. Ai eu pensei assim, biologia é mais abrangente, eu acho que é mais a minha cara. Ai eu fiz biologia.

Turno 5: [Entrevistador]: E por que na USP?

Turno 6: [Mediador N2]: Então... Prestei é... Porque eu pensei assim, eu moro em São Paulo, sempre morei aqui, eu moro do lado da USP e ai eu prestei USP, prestei Unicamp, prestei é... Pelo ENEM eu entrei na São Carlos, em biologia também. Mas ai como eu entrei na USP era minha primeira opção, porque além de ser muito renomada e tudo, é muito perto, muito bom pra mim

Turno 7: [Entrevistador]: E você faz... No caso você tem licenciatura e bacharelado, você quer escolher um ou outro ou vai fazer as duas?

Turno 8: [Mediador N2]: Então, eu não sei ainda o que eu quero fazer. Mas eu acho que faria licenciatura de qualquer modo.

Turno 9: [Entrevistador]: Mas você se vê dando aula?

Turno 10: [Mediador N2]: Mais ou menos (riso). Acho que... Acho que é muito difícil dar aula, assim. Eu não sei se eu sou muito... Ah, eu não sei dizer. Porque acho que é um desafio que você tem que ser um professor muito incisivo pra você conseguir chegar nos alunos. Eu vejo isso pela experiência que eu tive como aluna, sabe. Você tem... Os professores, por mais que eles saibam muito, você precisa saber passar aquilo, senão não adianta nada. E eu não sei se eu lidaria bem com isso, porque eu acho que é... Não sei se é a minha praia. Teria que experimentar. Eu tô meio aberta, mas não é a minha primeira opção, assim, nossa preciso ser professora, sabe.

Turno 11: [Entrevistador]: Então, você vai seguir a área da pesquisa?

Turno 12: [Mediador N2]: Então, na verdade eu não faço a menor ideia.

Turno 13: [Entrevistador]: Não sabe ainda. 
Turno 14: [Mediador N2]: É... eu tô bem assim... Bem perdidona mesmo.

Turno 15: [Entrevistador]: Entendi. E você já trabalhou em alguma coisa antes de entrar aqui na USP?

Turno 16: [Mediador N2]: Não, nunca trabalhei.

Turno 17: [Entrevistador]: Nem informalmente?

Turno 18: [Mediador N2]: Não. É... Só assim, projetos assim, mas é mais ligada a escola mesmo.

Turno 19: [Entrevistador]: E o projeto que mais te chamou atenção foi só esse de biologia ou teve algum outro?

Turno 20: [Mediador N2]: Não. Mas é que é assim, por exemplo, eu faço um projeto no meu antigo colégio que é um projeto de ex-alunos mesmo. E ai é um evento que acontece todo ano, chama encontro de jovens e, alias, é final de semana que vem e é por isso que eu tô meio louca agora. E é assim, nesse final de semana que a gente convida os alunos para irem lá, tem um número certo de alunos, tudo mais. A gente dorme no colégio, faz como se fosse um retiro mesmo, pra discutir várias coisas que a gente já tá discutindo desde março. A gente monta o material, monta um monte de atividade, dá muito trabalho. E assim, só que não ganha nada. É voluntário e o retorno é totalmente...

Turno 21: [Entrevistador]: Mas é sobre o que exatamente?

Turno 22: [Mediador N2]: Então, varia muito. É um tema específico, mas é sempre abrangente. É coisas que... A gente tenta relacionar sempre ao cotidiano das pessoas que estão no colegial agora. Não pode ser algo distante, lógico. Mas assim, varia muito. Falaram já sobre caminhos, tipo escolhas que é um momento que você vai escolher um monte de coisas, escolher os cursos de faculdade. Sobre a relação com o outro sabe você, o outro o grupo. Essas coisas... É bem abrangente assim. Só que tem vários ângulos. Você pode sentar e discutir. Tem umas partes mais assim, sentar e discutir. Tem outras que é assim tipo uma brincadeira, tipo uma gincana assim.

Turno 23: [Entrevistador]: É mais uma ajuda pros alunos?

Turno 24: [Mediador N2]: É... Não sei se é bem uma ajuda. É um momento de você ficar lá, vamos fazer uma coisa diferente. Vamos sair da rotina e pensar numas coisas que você não pensaria todo dia, sabe. Acordar, ir pra escola... Ir pro cinema. Uma rotina assim que o pessoal costuma seguir. É pra propor umas coisas novas. Então, a gente gosta de cutucar eles. Ah, agora você vai fazer essa atividade em dupla com alguém que você nunca viu. Ah, que 
estranho. Mas é bem isso. É pra promover novas trocas, coisas que você não faria numa... Numa situação normal. É isso. Acho que esse é o projeto que eu mais me envolvi. E ai eu fiz pequenos projetos dentro do meu colégio assim.

Turno 25: [Entrevistador]: Entendi. E... Você está quanto tempo na Estação Biologia?

Turno 26: [Mediador N2]: Eu tô desde o começo desse ano.

Turno 27: [Entrevistador]: E você decidiu entrar na Estação Biologia por quê?

Turno 28: [Mediador N2]: Eu olhei no manual dos bichos e falei, nossa eu quero fazer essa ai. Porque achei... Ah, eu queria assim entrar pra... Porque tava falando que trabalha com criança e tal, eu acho que é um desafio legal pra mim. Não me dou particularmente bem com as crianças, mas eu acho muito legal ir lá e falar com elas e ver o que elas tem pra dizer. Eu acho muito interessante ver o jeito que elas entendem o mundo. Eu achei que ia ser um lugar bom pra isso. E... Ah... E é muito bonitinho assim. É muito legal fazer parte disso, cuidar de tudo que tem que cuidar. A estrutura toda. Eu fiquei impressionada de ver como funciona, de como dá certo.

Turno 29: [Entrevistador]: No caso, qual é a sua função na estação biologia? O que você fez até então? Tem alguma função específica?

Turno 30: [Mediador N2]: Não, não tenho função específica ainda. Ainda não fiz nenhuma das manutenções. Eu tô marcada pra fazer isso no final do mês. Ai, eu não tenho uma função assim. Por enquanto, eu só pensei numa atividade ai, dei uma pincelada.

Turno 31: [Entrevistador]: Com que frequência você vai à EB?

Turno 32: [Mediador N2]: Então, oficialmente uma vez por semana. Mas na última semana eu fui bastante, porque eu arranjei um escorpião. O escorpião foi eu quem trouxe do interior. Ai eu fui vários dias pra checar lá como tava o andamento. O pessoal pediu pra eu levar e dai eu fui lá pra ver.

Turno 33: [Entrevistador]: De quantas visitas você já participou?

Turno 34: [Mediador N2]: Uma.

Turno 35: [Entrevistador]: E... Foi pra Ensino Médio, Ensino Fundamental?

Turno 36: [Mediador N2]: Foi pro segundo ano do Ensino Médio.

Turno 37: [Entrevistador]: Segundo ano. Você gostou da experiência?

Turno 38: [Mediador N2]: Gostei. Foi legal participar. É... Eu fiquei numa coisa mais bastidores, mesmo. Eu fiquei contando o tempo. Ai, teve até aquela parte, acho que você tava 
na mesa comigo da parte da genética? Eu tava na mesa ali, dai eu falei um pouco com os alunos, expliquei algumas coisas e achei que foi, assim, um pouco... Ah... Qual a palavra? Foi divertido.

Turno 39: [Entrevistador]: E o que você fez, foi escolha sua ou alguém colocou pra você fazer?

Turno 40: [Mediador N2]: O tempo?

Turno 41: [Entrevistador]: É.

Turno 42: [Mediador N2]: Então, foi escolha minha, mas foi sugestão também. Assim: "Ah, sua primeira visita, é mais legal você ficar observando". Tanto que eu fiquei, quando eu contei o tempo lá fora, eu fiquei ouvindo o que os outros monitores estavam falando pros grupos. Ai eu já tenho uma ideia do que eles costumam falar e como é a dinâmica.

Turno 43: [Entrevistador]: Qual a atividade que você mais gostou da EB? Ou que você participou ou que você viu alguém fazendo?

Turno 44: [Mediador N2]: Eu acho que a dos "escoisos", que é de genética. Gosto bastante dessa atividade. E... A trilha da biodiversidade. Acho que são as mais legais.

Turno 41: [Entrevistador]: Que público você prefere anteder? Eu sei que você só acompanhou ensino médio até agora, mas na sua experiência assim qual você acha que você se daria melhor?

Turno 42: [Mediador N2]: Acho que o que eu prefiro talvez seja ah... Não sei dizer. Não, eu prefiro as crianças assim com sete anos. Eu acho que eu me divirto mais. Mas talvez eu me de melhor com as crianças de colegial. Com as crianças (risos)... Com os adolescentes.

Turno 43: [Entrevistador]: Entendi. E pra você qual é o objetivo da Estação Biologia?

Turno 44: [Mediador N2]: Humm... Acho que... Tanto fazer uma coisa para a comunidade, porque as escolas vem e todos os visitantes vão levar alguma coisa daqui ou pelo menos é o que a gente espera ne. Então uma coisa de divulgar mesmo, mais cultura assim, mais informação. Mas eu acho que é um aprendizado pra todo mundo que participa. Pra todos os monitores. Eu diria que talvez mais do que trazer uma coisa pra sociedade, eu vejo como se fosse um laboratório, fosse um aprendizado pro pessoal que tá aqui. Porque tudo isso que a gente tá fazendo é ganhar experiência. E depois quando sair daqui isso vamos levar com a gente e lógico que tem um retorno pra sociedade. É então eu acho que é meio mútuo (risos).

Turno 45: [Entrevistador]: Então você acha que a Estação Biologia te ajudaria na sua formação profissional? 
Turno 46: [Mediador N2]: Com certeza.

Turno 47: [Entrevistador]: Mas especificamente assim, por quê?

Turno 48: [Mediador N2]: Porque trabalha muito com comunicação e... Tanto entre os monitores quanto informativa mesmo. Você tem que ir lá, tem que explicar uma coisa e você tem que se fazer entender. É bem essa coisa de professor mesmo ne, que também tem que se fazer entender. Lógico que numa escala menor. Mas acho que nesse sentido comunicação, assim, eu colocaria em primeiro lugar, organização e comprometimento.

Turno 49: [Entrevistador]: Certo. E pra você quais são os pontos fortes e fracos da Estação Biologia?

Turno 50: [Mediador N2]: Humm... Eu acho muito difícil dizer isso, porque eu tô muito pouco tempo. É... Não sei responder. Ah... Um ponto forte... Ah, acho que um ponto forte vai é que assim, como as pessoas estão lá por que elas querem, acho que tem muita força de vontade ali. Então, tem essa energia assim: "ah, vamos fazer, vamos fazer dar certo." Acho que bem perceptível isso. E ponto fraco... Ah... Eu não sei. Eu sei que tem alguns problemas aqui e ali ne. Mas acho que são problemas que acontecem. Tipo não ter ninguém pra cuidar de alguma coisa que tem que cuidar. Ai acho que eu não sei responder.

Turno 51: [Entrevistador]: E em relação a você, quais são os seus pontos fortes, as suas qualidades que você acha que ajuda ou que ajudaria na Estação Biologia?

Turno 52: [Mediador N2]: tá. Acho que eu sou uma pessoa comunicativa. Acho que eu tenho facilidade pra isso. É... E acho que eu gosto de por ordem também. E precisa ne. Precisa de gente de todo tipo. Acho que nesse sentido de fazer com que as coisas não desandem muito assim. Tipo, quando eles começam a pirar muito assim, trazer mais pro chão. Acho que eu faço isso também.

Turno 53: [Entrevistador]: E você gosta de trabalhar assim como mediador? Você se enxerga de repente continuando trabalhando nisso? Ou até mesmo ir pra outro local, como um museu, para trabalhar como mediador?

Turno 54: [Mediador N2]: É... É uma possibilidade. Acho que sim.

Turno 55: [Entrevistador]: Tem algum motivo específico?

Turno 56: [Mediador N2]: Ah, eu gosto.

Turno 57: [Entrevistador]: Pretende participar ou já participou de alguma elaboração, criação de atividade na EB?

Turno 58: [Mediador N2]: É, então, eu tô elaborando uma agora e... Então, sim ne. 
Turno 59: [Entrevistador]: Sobre o que?

Turno 60: [Mediador N2]: É... Sobre pássaros. É uma atividade pra trabalhar com diferentes sentidos. Então, a gente tá trabalhando audição, principalmente, pra falar dos cantos dos pássaros e visão. A gente acabou de ter essa ideia assim, uma coisa meio... Mas separar as duas ne. Pra não ficar muito influenciado, porque a visão puxa muito.

Turno 61: [Entrevistador]: E é só você que tá...?

Turno 62: [Mediador N2]: Não. Sou eu... Eu tava trabalhando eu, o mediador N1 e o mediador $\mathrm{N} 3$.

Turno 63: [Entrevistador]: E como você se vê daqui a um tempo na Estação Biologia, daqui há uns 4 ou 5 meses?

Turno 64: [Mediador N2]: Então, acho que vou tá... Eu espero que eu esteja mais familiarizada com tudo, porque eu tô me sentindo meio perdida, assim: "nossa, não sei do que eles estão falando." Então acho que é isso. Mais dinâmica e tal. E... Mais em casa.

Turno 65: [Entrevistador]: Mas o que?

Turno 66: [Mediador N2]: Em casa.

Turno 67: [Entrevistador]: Em casa.

Turno 68: [Mediador N2]:Porque o clima é muito gostoso. Mas, às vezes, eu acho que não tô muito familiarizada com o lugar mesmo. Acho que é isso, assim. Mas autonomia pra pegar e falar: "ah, eu faço isso sozinha" ou "posso ajudar tal pessoa". Mais autonomia.

Turno 69: [Entrevistador]: Tem mais alguma coisa que você queira falar da Estação Biologia? Alguma coisa de você, que você acha importante?

Turno 70: [Mediador N2]: Não. Acho que é isso. É.

Turno 71: [Entrevistador]: Então, tá bom. Então, é isso. Obrigada.

Turno 72: [Mediador N2]: Imagina.

São Paulo, 18 de Maio de 2012.

$1^{\text {a }}$ Entrevista com mediador Novato 3 (N3) da Estação Biologia.

Turno 1: [Entrevistador]: Quantos anos você tem?

Turno 2: [Mediador N3]: 18.

Turno 3: [Entrevistador]: 18 anos. Quanto tempo está na biologia? 
Turno 4: [Mediador N3]: 3 meses.

Turno 5: [Entrevistador]: Mas por que você escolheu fazer biologia?

Turno 6: [Mediador N3]: Ah, isso é desde pequena. É... Eu meio que não sei, porque eu quero isso desde pequena, então, acho que eu até esqueci o motivo. Assim, desde pequena eu sempre queria ser bióloga marinha.

Turno 7: [Entrevistador]: Por que você escolheu fazer biologia na USP?

Turno 8: [Mediador N3]: Porque é uma faculdade boa, com um nome famoso, boas indicações e eu já tinha parentes que já tinham feito já aqui. Então, era a faculdade que pra mim é... é muito...não tenho palavras... grande e legal. Por isso, escolhi ela.

Turno 9: [Entrevistador]: E você faz licenciatura e bacharelado... Na verdade você está no básico agora ne?! Mas você pretende fazer as duas ou vai escolher uma das modalidades?

Turno 10: [Mediador N3]: O curso de biologia, tanto bacharelado quanto a licenciatura, é junto né. A gente não tem escolha.

Turno 11: [Entrevistador]: Ah, aqui não tem escolha, você não pode abandonar uma.

Turno 12: [Mediador N3]: Não.

Turno 13: [Entrevistador]: Mas você pretende focar em que, na pesquisa ou na área de ensino?

Turno 14:[Mediador N3]: Eu sempre ouvi dizer que as pessoas que sempre quiseram pesquisa, uma hora bate a vontade de dar aula. E eu acho que eu não vou ser diferente (risos).

Turno 15: [Entrevistador]: E qual é a área da biologia que mais te interessa? Continua sendo a marinha?

Turno 16: [Mediador N3]: A parte de pesquisa na filogenia também me atrai bastante. Eu não sei... Como eu ainda estou no começo do curso, ainda tem alguns caminhos que eu tenho que saber para...

Turno 17: [Entrevistador]: Então o que te interessa é filogenia e essa parte da marinha?

Turno 18: [Mediador N3]: Isso.

Turno 19: [Entrevistador]: Você já trabalhou com alguma coisa antes de entrar aqui na USP? Ainda trabalha?

Turno 20: [Mediador N3]: Não.

Turno 21: [Entrevistador]: Nem informal, assim?

Turno 22: [Mediador N3]: Não. 
Turno 23: [Entrevistador]: Tá bom. Quanto tempo você esta na Estação Biologia?

Turno 24: [Mediador N3]: Acho que mais ou menos 3 meses também.

Turno 25: [Entrevistador]: E por que você escolheu entrar na Estação Biologia?

Turno 26: [Mediador N3]: Isso é porque eu tenho muita vergonha de falar em público. E eu achei que talvez fosse uma forma de eu começar a me soltar um pouco mais. Pra conseguir falar na frente das pessoas, explicar.

Turno 27: [Entrevistador]: Qual é a sua função? O que você já fez na Estação Biologia?

Turno 28: [Mediador N3]: É... Fiz a manutenção e fiz uma apresentação do aquário.

Turno 29: [Entrevistador]: Humm... Legal. Com que frequência você vai na Estação Biologia?

Turno 30: [Mediador N3]: Uma vez por semana.

Turno 31: [Entrevistador]: Uma vez por semana? Normalmente na sexta-feira, ne?

Turno 32: [Mediador N3]: Isso.

Turno 33: [Entrevistador]: De quantas visitas você já participou?

Turno 34: [Mediador N3]: Uma só.

Turno 35: [Entrevistador]: Que atividade você fez? Você gostou?

Turno 36: [Mediador N3]: Eu apresentei o aquário e... Ah, eu achei legal assim. Achei uma experiência diferente. Foi bom.

Turno 37: [Entrevistador]: Qual atividade que você mais gostou na Estação Biologia? Ou que você fez ou que você viu alguém fazendo?

Turno 38: [Mediador N3]: Humm... A de biodiversidade e atividade de genética e de seleção natural também.

Turno 39: [Entrevistador]: Qual público que você prefere atender, Ensino Médio ou Fundamental? Essa visita (referindo-se a visita que o mediador N3 participou) foi... ?

Turno 40: [Mediador N3]: Ensino Médio.

Turno 41: [Entrevistador]: Ensino Médio. Qual você acha que você se dá melhor?

Turno 42: [Mediador N3]: Ah, como eu ainda não fiz com criança, então, não tenho como comparar. Mas eu gosto de criança, então...

Turno 43: [Entrevistador]: Pra você qual é o objetivo da Estação Biologia? 
Turno 44: [Mediador N3]: Humm... Meio que mostrar pras crianças e adolescentes que vem aqui mais como é a profissão de um biólogo. Porque tem aquela visão muito: mexer só em bicho, ficar se metendo no meio do mato. E não é só isso, ne. Acho que é também, ensinar coisas diferentes com outros meios.

Turno 45: [Entrevistador]: Humm... Legal. E você enxerga a Estação Biologia como um espaço de Educação Não Formal?

Turno 46: [Mediador N3]: Como?

Turno 47: [Entrevistador]: Você acha que a Estação Biologia ela é um espaço de Educação Não Formal?

Turno 48: [Mediador N3]: Não formal?

Turno 49: [Entrevistador]: É.

Turno 50: [Mediador N3]: Não sei responder (risos).

Turno 51: [Entrevistador]: No seu ponto de vista, quais são os pontos fortes e fracos da Estação Biologia?

Turno 52: [Mediador N3]: Pontos fortes eu acho que são... A forma diferente de ensino. Que... Eles usam muitos materiais, outras formas de mostrar o que se passa por trás daquilo que ele vê em livro, ne. E... Ponto fraco... Humm... (risos). Talvez, às vezes, a falta de um professor pra, às vezes, organizar os alunos. Assim... As pessoas que estão lá são só alunos, ne. Então, às vezes, a gente fica meio perdido quanto o nível da escola que vem visitar a gente. Isso, às vezes, atrapalha a apresentação.

Turno 53: [Entrevistador]: E quais são os pontos fortes que você enxerga em você que você acha que contribui ou contribuiria com a Estação Biologia?

Turno 54: [Mediador N3]: Humm...

Turno 55: [Entrevistador]: As suas qualidades?

Turno 56: [Mediador N3]: Ah... Eu acho que criatividade, talvez, pra criar algumas saídas para problemas. Mais isso mesmo, sabe. E o fato de gostar de biologia (risos).

Turno 57: [Entrevistador]: E... Você acredita que a Estação Biologia pode te ajudar na sua formação profissional?

Turno 58: [Mediador N3]: Acho. Por isso mesmo que eu entrei. Porque, além de eu conseguir falar mais em público, conseguir explicar de forma sintetizada e criando um valor de formação. Num curto espaço de tempo. Eu acho que é isso. 
Turno 59: [Entrevistador]: Você participa, já participou ou pretende participar da elaboração, da criação de atividades na Estação Biologia?

Turno 60: [Mediador N3]: Eu já dei ideias. É... Preparar um aquário... O protocolo do aquário. Fazer o canto dos pássaros, eu dei algumas opiniões, mas apenas isso.

Turno 61: [Entrevistador]: Como você se enxerga daqui a um tempo na Estação Biologia? Daqui há um seis, quatro meses?

Turno 62: [Mediador N3]: (Risos) Nunca parei pra pensar. Ah... Não muito diferente, não sei. Talvez um pouco mais solta, talvez um pouco mais... Menos presa nas minhas barreiras de não conseguir falar direito com as pessoas.

Turno 63: [Entrevistador]: E... Você gosta de atuar como mediadora? Você se vê trabalhando em um outro local que não seja a Estação Biologia? Em um museu?

Turno 64: [Mediador N3]: Eu gosto. Eu acho legal dar aula.

Turno 65: [Entrevistador]: Você se vê dando aula, no caso?

Turno 66: [Mediador N3]: Humm... Não. Eu gosto mais da pesquisa e do campo, mas eu não rejeito a hipótese de acabar dentro da área de ensino.

Turno 67: [Entrevistador]: Então, ta bom. Muito obrigada.

São Paulo, 18 de Maio de 2012.

\section{$1^{\text {a }}$ Entrevista com mediador Novato 4 (N4) da Estação Biologia.}

Turno 1: [Entrevistador]: Quantos anos você tem?

Turno 2: [Mediador N4]: 18.

Turno 3: [Entrevistador]: Quanto tempo está na biologia?

Turno 4: [Mediador N4]: Eu entrei em fevereiro. Então, 3 meses.

Turno 5: [Entrevistador]: Por que você escolheu fazer biologia?

Turno 6: [Mediador N4]: Sempre, desde de pequeno eu gostei de biologia. Gostava de pesquisar coisas. Eu sempre gostei de natureza, então, pesquisa e natureza, nada melhor. Encaixou, assim, dois dos meus maiores gostos.

Turno 7: [Entrevistador]: Legal. E por que você escolheu fazer USP?

Turno 8: [Mediador N4]: Porque ela é a... Eu acho que ela é a... Apresentava muitas matérias que eu queria ter. Eu também ouvi que o forte dela é a zoologia, que é o que eu pretendo seguir na biologia. 
Turno 9: [Entrevistador]: Você faz licenciatura e bacharelado?

Turno 10: [Mediador N4]: É, por enquanto a gente não escolheu ainda, mas eu vou fazer os dois.

Turno 11: [Entrevistador]: Vai fazer os dois. E por que você vai fazer os dois?

Turno 12: [Mediador N4]: Ah, porque como os nossos próprios professores falam, é importante mesmo que... Eu quero seguir pesquisa, ne, mas mesmo um pesquisador precisa ter didática pra passar o conhecimento que ele adquiriu. Então... E também, quem sabe um dia... Ser professor. Quanto mais aberto estiver o meu leque de opções melhor, entendeu.

Turno 13: [Entrevistador]: Mas a sua intenção então é ficar na área da pesquisa?

Turno 14: [Mediador N4]: Sim.

Turno 15: [Entrevistador]: Tá. E você já falou zoologia, tem mais alguma outra área que te chama atenção?

Turno 16: [Mediador N4]: Não, mais a zoologia mesmo. Diferentes partes da zoologia, mas nada assim com grandes partes. Zoologia só.

Turno 17: [Entrevistador]: Entendi. Você já trabalhou antes de entrar na USP ou ainda trabalha?

Turno 18: [Mediador N4]: Tipo, só informal, coisas bem leves, mais bicos assim.

Turno 19: [Entrevistador]: Mas o que? Relacionado à que?

Turno 20: [Mediador N4]: Eu ajudava a organizar uma empresa de um amigo meu, ai recebia um trocado. Eu ganhava assim, eu já toquei... Não é um emprego, mas tipo, eu já toquei, minha banda tocava e eu ganhava uma grana com isso.

Turno 21: [Entrevistador]: Ah, você toca? Tem banda?

Turno 22: [Mediador N4]: Sim. Tenho uma banda.

Turno 23: [Entrevistador]: Legal.

Turno 24: [Mediador N4]: E é mais ou menos assim. Nada formal, nada com carteira assinada.

Turno 25: [Entrevistador]: Ah, não. Sem problema. E alguma coisa relacionada à educação, à biologia?

Turno 26: [Mediador N4]: Não. Mas eu ajudava tipo... A coisa mais próxima de ajudar com educação que eu fiz é dar aula de reforço em algumas matérias.

Turno 27: [Entrevistador]: Ah, legal. Você dava aula ou ajudava tipo parente? 
Turno 28: [Mediador N4]: Não, eu dava uma espécie de recuperação, como se fosse uma aula de reforço na minha escola antiga. Só que pros bem mais novos, tipo Ensino Fundamental II.

Turno 29: [Entrevistador]: Ah, entendi. Legal. Quanto tempo você está na EB?

Turno 30: [Mediador N4]: Na EB? Um mês, porque foi quando a gente entrou. A gente teve praticamente um mês de treinamento e assim que acabou o treinamento eu entrei. Então deve dar um mês, um mês e um pouquinho.

Turno 31: [Entrevistador]: Certo. Quando que foi esse treinamento? Você lembra?

Turno 32: [Mediador N4]: Ai... A data exata tá no mural do lado de fora da EB, assim. Mas foi no meio de março até meio de abril, mais ou menos.

Turno 33: [Entrevistador]: Entendi. Por que você decidiu entrar na EB?

Turno 34: [Mediador N4]: Ah, porque eu gostei da proposta da entidade ne, que é educar de uma forma mais lúdica. Que nem tipo, eu gostava muito de biologia, mas no Ensino Médio o que eu gostava caiu bastante, porque eu tinha uma professora que era muito pouco lúdica. Então... E ai, tipo, eu quis ir atrás da formação na biologia, então, eu acabei voltando a gostar por causa disso. Dai eu percebi, tipo, a biologia você tem que mostrar de uma forma mais... É... Não pelo livro, entendeu? Você tem que mostrar o real, assim. Isso que é legal. E na EB a proposta é bem parecida com o que eu pensava. Eu falei: "Não, perfeito. Eu quero fazer parte disso".

Turno 35: [Entrevistador]: Ah, legal. E ai, só pela proposta e a equipe em si isso não...

Turno 36: [Mediador N4]: Não, não influenciou, porque todos eles são meus amigos e tal. Então, tipo, o fato de ser amigo deles não foi tanto, entrei pela proposta da entidade mesmo.

Turno 37: [Entrevistador]: Você tem alguma função assim na EB?

Turno 38: [Mediador N4]: Específica? Não. É... Pessoalmente porque a gente começou agora, a gente não tem muita função específica. A gente faz tudo que cabe a gente.

Turno 39: [Entrevistador]: Mas ai você ajuda em que, assim?

Turno 40: [Mediador N4]: Ah, tipo uma regra ou que eu já fiz até agora?

Turno 41: [Entrevistador]: O que você fez até agora?

Turno 42: [Mediador N4]: Ah, então ajudei nos negócios das cobras que eu estou fazendo inclusive há umas quase duas semanas. Eu tô ajudando a tentar bolar alguma atividade sobre animais peçonhentos com o pessoal da comissão de quinta. É uma coisa paralela. E... também trabalhos de manutenção e conserto de coisas nossas, de material nosso. 
Turno 43: [Entrevistador]: Humm legal.

Turno 44: [Mediador N4]: Só coisa bem básica, por enquanto.

Turno 45: [Entrevistador]: Com que frequência você vai na EB?

Turno 46: [Mediador N4]: Uma vez por semana. Algumas vezes duas vezes por semana, mas nessa segunda vez não passa de uma hora. Só uma passada pra fazer alguma coisa.

Turno 47: [Entrevistador]: Normalmente é na sexta-feira de manhã?

Turno 48: [Mediador N4]: Normalmente.

Turno 49: [Entrevistador]: Tá. De quantas visitas você já participou?

Turno 50: [Mediador N4]: Uma.

Turno 51: [Entrevistador]: Uma? Gostou?

Turno 52: [Mediador N4]: Sim, muito.

Turno 53: [Entrevistador]: Qual foi a atividade que vocês fizeram nessa visita?

Turno 54: [Mediador N4]: Foi do... Foi, ai, esqueci o nome. Foi tipo um debate sobre o novo código florestal. Esqueci o nome da atividade, mas ai, tipo, tinha as crianças e a gente tinha que ajudar elas a pensar em argumentos. Era dividida em quatro grupos e cada grupo, tipo, fazendeiros, políticos pró, políticos contra e ONG, por exemplo. Ai, tinha que fazer todo mundo pensar em argumentos e tal. Eu gostei bastante disso ai. Principalmente porque eu não dei nenhuma informação pra eles. Eu ajudei eles a concluir.

Turno 55: [Entrevistador]: Foi pra Ensino Médio?

Turno 56: [Mediador N4]: Foi.

Turno 57: [Entrevistador]: Certo. Qual atividade que você mais gosta ou gostou até agora na $\mathrm{EB}$ ?

Turno 58: [Mediador N4]: Humm...

Turno 59: [Entrevistador]: Que você já viu alguém aplicando ou que você participou?

Turno 60: [Mediador N4]: Então, eu ainda não participei... Eu não participei, mas eu tenho certeza que vai ser a que eu vou gostar mais, que é o bicho-pau. É o mais próximo o que eu falei sobre deixar lúdico, ai você dá o bicho pra pessoa segurar assim. Então, é o mais próximo possível que eu posso chegar, então, eu acho que é a que eu mais vou gostar, assim. Que é a mais lúdica possível.

Turno 61: [Entrevistador]: Certo. Qual público que você prefere atender, assim? Você ainda não atendeu os dois, ne? 
Turno 62: [Mediador N4]: Sim, sim.

Turno 63: [Entrevistador]: Mas, assim, como você se enxerga?

Turno 64: [Mediador N4]: Eu prefiro criança mais nova assim.

Turno 65: [Entrevistador]: Mais nova, ne? Por quê?

Turno 66: [Mediador N4]: Sei lá. Acho que eu me dou melhor com criança do que com Ensino Médio. Acho que principalmente porque eu até seis meses atrás eu era do Ensino Médio, então, acho que tá muito próximo pra eu saber direito como lidar, numa postura mais de professor assim. Como está muito próximo pra mim, eu não consigo me imaginar ensinando alguém de Ensino Médio. Mas agora os mais novos é mais fácil. Principalmente, porque eu fazia isso na minha escola, onde eu ajudava eles com os trabalhos e tal. Então, eu meio que já estou acostumado.

Turno 67: [Entrevistador]: Entendi. E pra você qual é o objetivo da Estação Biologia?

Turno 68: [Mediador N4]: Educar de forma lúdica (risos) a biologia, assim. Ensinar uma forma diferente do que as crianças aprenderiam em sala de aula.

Turno 69: [Entrevistador]: Uhum. Legal. Você enxerga a Estação Biologia como um espaço de Educação Não Formal?

Turno 70: [Mediador N4]: Não formal? Não sei não formal ainda. Não sei qual é o conceito de formal ou não. Ah, pode ser não formal porque teoricamente nós não somos professores fixos, ne. É como se fosse uma excursão. É... Eu acho que é ensino não formal sim.

Turno 71: [Entrevistador]: Certo. No seu ponto de vista, quais são os pontos fortes e fracos da Estação Biologia?

Turno 72: [Mediador N4]: O forte eu diria que as atividades são muito bem feitas, muito bem conceituadas e, ao meu ver, elas estão muito bem encaixadas na proposta delas. Agora o ponto fraco... Assim, eu não estou há tanto tempo para ver um ponto fraco, assim. Por enquanto pra mim está tudo bem. Talvez, fosse a... Toda a papelada, toda a burocracia que é pra conseguir um pouco de verba. Eu acho que talvez seria isso o ponto fraco.

Turno 73: [Entrevistador]: E em você, quais são os pontos fortes que você enxerga em você que você acha que contribui ou que contribuiria com a Estação Biologia?

Turno 74: [Mediador N4]: Bem, eu tenho toda a... A meu ver, eu tenho toda a... Eu tenho a mesma ideia que eu entendi pra conceito da EB, então, como eu sigo essa ideia, talvez, eu tenha... Combina comigo e eu posso dar o meu melhor e se possível fazer a entidade só melhorar. Como eu estou comprometido com esse negócio de ser lúdico e informativo, talvez, 
eu consiga ir bem pra conseguir pensar numa atividade mais lúdica, assim. É isso que eu penso que eu possa contribuir.

Turno 75: [Entrevistador]: De maneira mais clara, quais seriam as suas qualidades assim? Estaria mais envolvido com a parte de criação, ou com manutenção, ou mesmo com a visita?

Turno 76: [Mediador N4]: Eu gosto dos três, então, eu não sei qual eu estaria mais envolvido.

Turno 77: [Entrevistador]: Você gosta dos três?

Turno 78: [Mediador N4]: Sim.

Turno 79: [Entrevistador]: Tá. Legal. Acredita que a Estação Biologia possa ajudar na sua formação profissional?

Turno 80: [Mediador N4]: Sim. Com certeza.

Turno 81: [Entrevistador]: Por quê?

Turno 82: [Mediador N4]: Por conta disso que eu já falei, que todo pesquisador tem que saber ensinar. E... Também, porque eu estou aprendendo coisas específicas, meio assim, talvez eu aprendesse isso mais pra frente, mas de qualquer forma, eu já estou fazendo na prática coisas que eu vou aprender só lá na frente, por exemplo, os negócios das cobras. Eu já tô ficando craque em taxonomia de cobras no primeiro semestre da graduação de tanto que eu já vi isso. Tem muitos conceitos que eu uso na sala que já estão sendo aplicados. Uma aula que eu tive sexta-feira passada eu vou aplicar hoje quando eu voltar.

Turno 83: [Entrevistador]: Aula de que?

Turno 84: [Mediador N4]: De sistemática.

Turno 85: [Entrevistador]: Ah, legal.

Turno 86: [Mediador N4]: Ensina a fazer uma chave com os animais assim. E eu peguei um livro sobre essa chave hoje, que agora vai ficar um pouco mais fácil de classificar as cobras.

Turno 87: [Entrevistador]: Legal.

Turno 88: [Mediador N4]: Bem interligado assim com a matéria.

Turno 89: [Entrevistador]: Entendi. Você gosta de trabalhar como monitor da Estação Biologia?

Turno 90: [Mediador N4]: Monitor, tipo visita?

Turno 91: [Entrevistador]: É. Na parte de mediação ne, como mediador.

Turno 92: [Mediador N4]: Sim, sim. Gosto. 
Turno 93: [Entrevistador]: Você se vê trabalhando, assim, ou na Estação Biologia, ou indo pra outro local pra continuar trabalhando como mediador? Ou você diria que é só momentâneo?

Turno 94: [Mediador N4]: Por enquanto eu diria que é só momentâneo aqui, mas tá passível de mudança (risos). É isso. Eu não sei. Tem muito tempo ainda e eu vou ficar muito tempo na EB se der certo. Então, tem muito tempo. Mas, tipo, se fosse hoje. Assim que eu terminasse meu curso, eu deixaria a EB pra me focar mais na pesquisa.

Turno 95: [Entrevistador]: Participa ou pretende participar da elaboração de atividades da Estação Biologia?

Turno 96: [Mediador N4]: Sim.

Turno 97: [Entrevistador]: Você já está participando ne?

Turno 98: [Mediador N4]: Então, eu vi que um mediador vai fazer uma atividade sobre animais peçonhentos e como eu sempre me interessei, fiquei sabendo, ai eu falei pro mediador: "oh, deixa que eu ajudo... Não sei o que". Ai dei alguma ideia remota assim, mas a gente tá pensando ainda. A gente tá se comunicando.

Turno 99: [Entrevistador]: Você gosta dessa parte de criação, então, também, ne?

Turno 100: [Mediador N4]: Sim, sim.

Turno 101: [Entrevistador]: Como você se vê daqui a seis meses na Estação Biologia?

Turno 102: [Mediador N4]: Humm... Daqui a seis meses?

Turno 103: [Entrevistador]: Ou menos, uns quatro. Daqui a um tempo, assim.

Turno 104: [Mediador N4]: Ah, como um monitor que já entende bem todos os conceitos já. Já sabe aplicar bem todas as atividades e que se dá melhor, sempre melhorando, com o pessoal que visita.

Turno 105: [Entrevistador]: Uhum. Tá. Tem mais alguma coisa que você queira falar da Estação Biologia? Alguma coisa de você que você acha que você esqueceu de falar, de repente?

Turno 106: [Mediador N4]: Não, não. Acho que foi bem isso. (risos).

Turno 107: [Entrevistador]: É? Então tá bom. É isso ai. Muito obrigada.

São Paulo, 20 de Setembro de 2013.

$2^{a}$ Entrevista com mediador Novato 1 (N1) da Estação Biologia. 
*OBS: Esta entrevista teve um pequeno erro técnico. Eu achei que o gravador estava gravando, mas não estava. Só fui perceber na terceira pergunta. Tive que começar de novo e, em algumas partes da entrevista, o mediador refere-se a esse acontecimento.

Turno 1: [Entrevistador]: Quanto tempo tá na EB?

Turno 2: [Mediador N1]: Tô há um ano e meio, vou fazer dois no fim do ano.

Turno 3: [Entrevistador]: Por que decidiu entrar na EB?

Turno 4: [Mediador N1]: Entrei na EB porque... Esqueci... (risos). Porque... Ah deu um branco agora, desculpa. (risos) ${ }^{*}$. Decidi entrar na EB pra desenvolver a minha didática, ne. Pra eu conseguir transpor o que eu... O conteúdo pra qualquer outro tipo de faixa etária, ne. Buscar falar o mesmo conteúdo, de uma mesma é... Mudar as complexidades dele e poder explicar pra diferentes faixas etárias. E é isso que a EB pode proporcionar pra gente. E porque eu quero seguir a área de professor. Quero dar aula sim e... Estou na biologia por causa de professores e... Eu quero passar pra frente não só... Passar esse conteúdo pra frente, não só ser pesquisador. É isso.

Turno 5: [Entrevistador]: Tá ótimo. E por que você resolveu continuar na EB?

Turno 6: [Mediador N1]: Continuar na EB, porque eu vi os resultados que tavam dando pra mim. E porque é... É... Porque eu tava vendo meu desenvolvimento aqui na EB em relação a transposição desses conteúdos e... Ai meu Deus... Eu esqueci. Não lembro tudo o que eu falei. Acho que eu falei outras coisas completamente diferentes (risos). Não foi isso ai. $\mathrm{E}^{*} \ldots \mathrm{E}$ porque é, é... Pra melhorar meu discurso também como um futuro professor. Eu tenho que perder a vergonha e também é...

Turno 7: [Entrevistador]: Você quer começar de novo?

Turno 8: [Mediador N1]: Ah eu quero (risos).

Turno 9: [Entrevistador]: Então vamos.

Turno 10: [Entrevistador]: Então vamos lá. Nome?

Turno 11: [Mediador N1]: Mediador N1.

Turno 12: [Entrevistador]: Quanto tempo você tá na EB?

Turno 13: [Mediador N1]: Um ano e meio. Vai fazer dois agora no fim do ano.

Turno 14: [Entrevistador]: Por que decidiu entrar na EB?

Turno 15: [Mediador N1]: Eu decidi entrar na EB, porque eu quero sim seguir a carreira de licenciatura e dar aula, ser um bom professor, além de ser um bom pesquisador e... Inspirar mais pessoas a entrar na biologia ne. E passar adiante esse conteúdo. 
Turno 16: [Entrevistador]: E o que te motivou continuar na EB?

Turno 17: [Mediador N1]: Continuar na EB é... Eu percebi a minha evolução como educador. Eu percebi minha evolução no discurso. Comecei a pegar mais firmeza pra falar em público e... Também exercitar mais a transposição do que eu estou pensando de um... Passar um conteúdo de formas diferentes, de linguagens diferentes pra... Tanto para pessoas mais leigas, até pra pessoas que são mais instruídas naquele assunto. E... Eu vendo essa minha evolução eu consegui, eu decidi continuar na EB.

Turno 18: [Entrevistador]: Tá ótimo. A gente conversou um pouco sobre a turma que entrou com você. Você me disse que mais da metade desistiu da EB. Por que você acha que essa maioria desistiu da EB?

Turno 19: [Mediador N1]: Bom, a maioria desistiu da EB eu diria, porque a EB tem um... Por enquanto, pretendo mudar isso (risos). Mas ela tem uma capacidade razoável de pessoas, assim. Não é pequena, mas ela tem uma capacidade é... Média de pessoas organizando ali. E o nível de comprometimento com a EB, tem pessoas que são muito mais comprometidas e também tem uma gradação de pessoas que são muito menos comprometidas. E é essas que são menos comprometidas, elas tendem a deixar a EB, conforme for passando o tempo e forem surgindo novas oportunidades para elas. Então se surge um estágio pra ela, ela começa a dar prioridade ao estágio e não à EB. Agora, aquelas que dão uma prioridade maior à EB, elas procuram... Elas dão prioridade à EB a um estágio. Em comparação a um estágio. E... Eu diria que essa gradação de comprometimento faz as pessoas saírem ne. Conforme for passando o tempo. E eu como um bolsista hoje, eu queria aumentar essa capacidade da EB.

Turno 20: [Entrevistador]: Como você acha que você poderia aumentar essa capacidade?

Turno 21: [Mediador N1]: Humm... Eu diria que aumentando a organização, por exemplo, de criação de novas atividades. Às vezes, as pessoas, elas tem boas ideias pra criação de atividades, mas não sabem ter um, um passo assim, é... Passo a passo de como finalmente aplicar essa atividade ne. Então, a gente tem muitas ideias, por exemplo, de... A gente tá tendo uma atividade de lixo agora, de descarte de lixo, lixo orgânico e inorgânico. É uma ótima ideia, mas as pessoas não estão sabendo levar até que a gente aplique numa visita. Se eu souber fazer uma metodologia de criação de atividade, vai ser um caminho fácil pra todas as pessoas que tem essas ideias boas, entendeu? Ai vai ter mais trabalho, tendo mais trabalho vai caber mais pessoas ali. Né? Acho que é assim. Ter uma organização melhor.

Turno 22: [Entrevistador]: É... Vou repetir uma pergunta. Na verdade, você falou, então, que a capacidade da EB é de manter poucas pessoas na organização, ne? 
Turno 23: [Mediador N1]: É... Manteria numa média 30, 40.

Turno 24: [Entrevistador]: Mas isso é diretamente, vocês falam pra pessoa: "oh, não dá pra você ficar" ou isso acontece indiretamente. Elas vão saindo por motivos...

Turno 25: [Mediador N1]: Não. É indiretamente. O que ocorre é que elas vão saindo por vontade própria. Na EB não tem nada obrigatório.

Turno 26: [Entrevistador]: Entendi. E... Qual é a sua função na EB?

Turno 27: [Mediador N1]: Bom, como bolsista agora, eu tô na função de relações internas, um RH. Então, basicamente eu tento integrar todas as comissões. Integrar as pessoas internamente. Então, eu tô na comissão de quinta e sexta, tento integrar essas duas. Mas também, eu sempre tento estar presente nas outras comissões pra poder saber o que está acontecendo em cada uma, como tá o desenvolvimento pessoal de cada monitor e... Fazer o bate bola entre eles e ter a visão geral do que ocorre dentro da EB. É... Eu também organizo as reuniões, ne, que eu acho que tendo essa visão geral da EB, eu posso organizar as reuniões e, também, apontar os principais defeitos pra poder orientar a galera quais são os próximos passos internos da EB. Relações internas.

Turno 28: [Entrevistador]: Legal. E... Você falou pra mim também que agora a turma de vocês organizou os bolsistas em departamentos.

Turno 29: [Mediador N1]: Sim.

Turno 30: [Entrevistador]: E quais são esses departamentos mesmo?

Turno 31: [Mediador N1]: Bom, vamos lá. Tem esse, relações internas, que eu estou. Tem relações externas que antes era o mediador V2, ai agora tá meio dividido entre eu, o mediador $\mathrm{C}$ e o mediador N2. A gente tem a parte financeira, que é o mediador M, que é bichete. A gente tem a parte de compras, que é o mediador T. Ele organiza o que deve ser comprado, a gente se reporta a ele o que precisa comprar. Tem a parte de divulgação, que é a o mediador To, que também é bichete. E tem... Esqueci de algum.

Turno 32: [Entrevistador]: Tem o mediador C.

Turno 33: [Mediador N1]: E tem o mediador C, que é uma coordenação pedagógica. Então, nesse caso, por exemplo, nesse passo a passo de criação de atividades eu acho que caberia a ele fazer ne. E ele avalia também as visitas e... Vê como pode melhorar as visitas, as atividades. E tá faltando o mediador N2. Eu não lembro o que ela faz (risos). Ai. Eu falei.

Turno 34: [Entrevistador]: Relações internas, externas, coordenador pedagógico, compra, divulgação, manutenção... 
Turno 35: [Mediador N1]: Ah, manutenção, mas não é o mediador N2. Manutenção, que é o mediador Tr, que é um bicho. O mediador N2 tá... Ai (risos). Ela sempre tá.

Turno 36: [Entrevistador]: Na turma anterior, o mediador V2 era identificado como um centro. E nessa turma, quem você identifica como centro da EB?

Turno 37: [Mediador N1]: Eu diria que eu, o mediador N2 e o mediador C, ne. Por a gente ser bolsista e por ser veterano entre os bolsistas ne.

Turno 38: [Entrevistador]: Tá. Ótimo. A frequência que você vem à EB?

Turno 39: [Mediador N1]: É, eu tenho, obrigatoriamente, duas vezes por semana, duas comissões por semana. No meu caso, quinta e sexta, como bolsista. Mas eu também tenho obrigação de fazer três manutenções por mês, como bolsista também. Porém, eu sempre estou por ai. Apareço nas comissões pra conectar. Às vezes, às vezes, eu tento fazer visita em outras comissões, também, e... E fora o trabalho externo que é acompanhar e-mails e tentar fazer criação de atividades por fora ne. Mas, obrigatoriamente, são isso que eu disse.

Turno 40: [Entrevistador]: De quantas visitas... Talvez quantas não, mas você já participou de muitas visitas até então.

Turno 41: [Mediador N1]: Bastante.

Turno 42: [Entrevistador]: É... O que você achou dessas experiências, tem alguma que te marcou que você gostaria de contar?

Turno 43: [Mediador N1]: Ai... No geral, eu sempre dou uma parada assim pra avaliar o impacto que aquilo tá dando pras crianças ne, pros alunos. E eu vejo que eles têm um ganho, além de conteúdo... Eles tem um ganho emocional daquilo ne. Eles ficam fascinados e você um bicho-pau ali na prática. E você tem uma aula de aquário com os bichos ali, ne. Então, eu acho que o ganho emocional deles, o brilho nos olhos que faz a EB ter essa diferença ne. É... Em particular eu lembro que, é... Acho que a primeira escola pública que veio aqui, que eu tive a primeira visita de escola pública, foi um impacto assim pra mim, porque... Eu nunca tive aquilo, eu nunca... Eu sou de escola pública também, ai rolou uma identificação, porque eu nunca tive contato com a biologia, com equipamentos de biologia, com animais, estudar na prática aquilo. Então, eu me via... Eu me olhei neles e falei: "meu, se eu tivesse essa estrutura, se tivesse pelo menos uma visita dessas, sabe, seria um impacto enorme na minha vida". E... É disso que a gente é feito, ne. De pequenas experiências que podem mudar rumos da nossa vida. É... Eu diria isso.

Turno 44: [Entrevistador]: E... Qual atividade que você mais gosta da EB?

Turno 45: [Mediador N1]: Hum... Ah... Eu gosto de todas (risos). 
Turno 46: [Entrevistador]: Não tem nenhuma que você prefere? Que você costuma apresentar?

Turno 47: [Mediador N1]: É... Eu gosto muito, ah... É uma que eu tenho apresentado muito, Esqueletos. Que é você... Você mostra os esqueletos, uma coisa, meu, que não tá viva, não se mexe e você começa a... Você faz aquilo se tornar muito interessante, através de fatos da estrutura óssea daquele bicho. É... Esse seria o meu preferido assim. Você pega dicas dele a partir do esqueleto dele, você consegue descobrir hábito alimentar, é... De que família ele é, se ele é uma ave ou não, se voa ou não, e... E fazer aquilo ficar interessante. Eu acho que isso é uma prova muito viva da transposição ne. Você tornar aquele conhecimento que, se você for pegar um livro pra ler é totalmente chato. Mas você fazer aquilo se tornar legal acho que é um grande ganho, assim. É um grande ganho. Então, eu acho que diria isso. Esse é um bem desafiador assim.

Turno 48: [Entrevistador]: Faz parte da trilha da biodiversidade essa parte dos esqueletos, ne?

Turno 49: [Mediador N1]: Sim.

Turno 50: [Entrevistador]: Você mudaria alguma coisa na atividade de esqueleto ou em alguma outra atividade?

Turno 51: [Mediador N1]: Na atividade de esqueletos, eu colocaria mais. Mais esqueletos ainda pra fazer comparação, por exemplo, é... Estrutura óssea e cartilagem. Colocar uma cartilagem de um tubarão lá pra fazer é... A... A comparação ne. Colocar estrutura de dentes pra tentar mostrar qual é carnívoro ou não a partir dos dentes. Ah, eu diria colocar mais. Mais esqueletos e não só deixar eles de modo expositivo.

Turno 52: [Entrevistador]: Pra você qual é o objetivo da EB?

Turno 53: [Mediador N1]: Tá. São basicamente três objetivos que eu vejo que a EB tem. Eu já esqueci um, mas tá. Primeiramente, é... Formar monitores, fazer futuros educadores. Então, os monitores, os graduandos daqui eles perdem... Aquela questão de perder mais a vergonha de falar em público, ter mais clareza na didática, é... Ser futuros professores, mesmo. Eu diria o segundo objetivo da EB é... Fazer materiais, materiais didáticos. Então, se a gente não tá fazendo visita a gente tá fazendo comissão. Então, na comissão é... Eu acho que a gente tem que trabalhar na criação de atividades e metodologias de ensinar uma coisa que já tem no currículo básico da escola, só que de maneiras diferentes, de maneiras mais práticas, mais divertidas, mais didática. Criação de atividades e materiais de atividades. E o terceiro objetivo seria... A transformação do próprio aluno que vem visitar. Ele ganhar não só uma carga de 
conteúdo quando vem aqui, mas também ganhar uma carga emocional. É... Fazer ele... Criar esses momentos de, de... De visita. Fazer com que eles se vislumbrem com a visita e assim, não, necessariamente, formar novos biólogos ne, a partir dessas crianças, desses adolescentes. Mas formar pessoas que tem noção disso que... Que não ignorem a biologia como uma coisa a parte, como uma coisa chata, uma coisa reservada só para os biólogos ne. E plantar um pouco de biologia neles.

Turno 54: [Entrevistador]: Tá ótimo. No seu ponto de vista, quais são os pontos fortes e os pontos fracos da EB?

Turno 55: [Mediador N1]: Pontos fortes da EB são... A carga prática da coisa ne. Que é uma coisa você se virar lá na frente. Você vai aprender, você vai criar sua própria metodologia mesmo. Nem sempre vai sair a mesma coisa que os outros, mas você vai se desenvolver. É... Criar pessoas mais autônomas, porque a EB tem essa estrutura que parece, parece um pouco pirâmide assim, mas a gente sempre prega pras pessoas elas terem autonomia. Eu sempre falo isso. É... Às vezes, as pessoas me perguntam: "ai, mediador N1, o que eu vou fazer agora? É... Deu tal problema. O que eu faço? "Ai eu falo: "E ai, o que que você acha?", sabe. Sempre pergunto (risos)... Fica na heurística pra própria pessoa ne (risos). Ensinando elas também. É fazer elas criarem essa autonomia. A EB criar... Não ser dividida em sistemas, mas células que sabem se virar ne. Criar sua autonomia. É... E, também, fazer o papel do terceiro tripé da USP que é a extensão. Que é a dívida que a universidade tem com a sociedade. Que é devolver o investimento que a sociedade faz pra... Devolver pra sociedade o investimento que faz na universidade. Que eu acho, eu considero assim muito fraca na USP e eu sinto muito orgulho de estar num projeto assim é... Aumentando esse índice de extensão que tem a USP. Eu diria que basicamente esses... Agora pontos fracos... Pontos fracos da EB? Organização. A gente tem problemas com organização, na nossa administração, assim. Eu tento... A gente tenta fazer essa estrutura de bolsistas é, como administradores assim, mas a gente... Tem coisas que a gente não sabe lidar, ne. É... Como, por exemplo, como, como... Como organizar as visitas... Como organizar as comissões de modo metódico assim. É... A gente tem alguns problemas organizacionais, que talvez isso faça com que as pessoas é, se desanimem mais. Mais facilmente e assim cria aquela taxa de evasão. Outro ponto fraco da EB... (pausa). Às vezes, por parecer uma coisa muito é... Descontraída, feita por alunos é... Fica parecendo que as pessoas tem pouco comprometimento, algumas ne. Uma taxa muito grande de descompromissos assim. E... É... Talvez essa coisa de não parecer uma coisa mais rígida faça com que seja uma coisa menos... Com pouco compromisso. Mas isso eu diria pra alguns ne. 
Ou metade eu diria (risos). Não sei eu não tenho a taxa disso. Mas esse é outro problema da EB.

Turno 56: [Entrevistador]: Entendi. E em você, quais são os pontos fortes que você enxerga em você que contribui pra EB?

Turno 57: [Mediador N1]: Tá. Um ponto forte em mim é que eu tenho uma certa dificuldade de prestar atenção em aula assim. E eu acho que essa minha deficiência faz com que eu consiga enxergar as pessoas que não tão entendendo a explicação. Então, é... É sempre aquela coisa, de voltar pra explicação mais simples sempre. Puxar de novo a explicação mais simples. Porque eu tenho essa dificuldade. É... Eu também tenho experiência em ensinar pra outras pessoas. É... Pessoas mais novas assim, desde sempre eu gosto muito de ensinar e de conversar sobre conteúdos variados com pessoas de categorias variadas. Então, eu acho que meu forte seria na didática assim. Eu acho que eu tenho uma certa clareza no que eu digo, em simplificar as coisas. E ponto fraco foi isso?

Turno 58: [Entrevistador]: Não. Só o ponto forte. É... No caso assim, quando você tá... Você falou que está no RH ne? Dos bolsistas?

Turno 59: [Mediador N1]: Uhum.

Turno 60: [Entrevistador]: Você, você falou que escolheu ficar nessa parte?

Turno 61: [Mediador N1]: Uhum.

Turno 62: [Entrevistador]: E você não enxerga é... Assim... Que característica sua você tem pra ter escolhido essa parte?

Turno 63: [Mediador N1]: Ah então, eu até tava comentando né, esses dias. Assim, é... Eu gosto muito de pessoas ne. Eu gosto muito. Percebo que eu posso estar no ambiente que for assim, eu acabo fazendo amigos. Eu acho pessoas interessantes, a pessoa pode ser um zero a esquerda qualquer dito por outros, eu consigo, sei lá... Explorar as pessoas. E... Eu acho que isso de... Seria uma característica forte. Eu gosto de conhecer pessoas diferentes e tentar estabelecer uma conexão entre essas pessoas diferentes ne. Eu acho que o fato... De eu estar aqui na USP é uma, já é uma vivência assim ne. Da onde eu vim é totalmente diferente desse local. Não fui instruído a entrar na faculdade nem... Minha cultura normal é ter que trabalhar e é isso ai, ne (risos). Fazer uma faculdade paga e é isso ai. De estar inserido nesse contexto aqui diferente, o contexto é... Universitário, já é um exercício pra mim. Então, eu gosto de conhecer pessoas diferentes sempre. É uma característica minha.

Turno 64: [Entrevistador]: Legal. E no mediador N2, o que você acha que é o ponto forte dele que contribui pra EB? 
Turno 65: [Mediador N1]: Ah, ele é... Eu gosto que ele não é... Ele é firme. Ele não é de "ah, faça de qualquer jeito". Não. Ele sabe dar bronca (risos). Ele sabe cobrar e, às vezes... Ele tem uma organização muito boa. Desde administrar as coisas, mas organização de pensamento. Às vezes, eu não consigo resolver uma coisa, ele tem um clique muito simples e resolve aquilo. Humm... Eu diria que é isso. E ele tem um nível de comprometimento alto também.

Turno 66: [Entrevistador]: E o mediador N3, qual o ponto forte dele?

Turno 67: [Mediador N1]: Ai caramba (risos). Ninguém tá vendo ne (risos). Ponto forte do mediador N3? (Pausa) É... Ele é comprometido.

Turno 68: [Entrevistador]: É comprometido?

Turno 69: [Mediador N1]: É... É o que fez ele tá até hoje com a gente ne. Ele é comprometido, bastante. Eu tenho pouca experiência de, de... Visitas com ele. Eu não sei como ele é na didática, na participação da didática. Mas ele tem... Ele é uma pessoa que eu posso contar, entendeu.

Turno 70: [Entrevistador]: E... Mas por que que é... Por exemplo, vocês entraram juntos. Você, o mediador $\mathrm{N} 2$ e o mediador $\mathrm{C}$ viraram bolsistas. E por que o mediador N3 não virou bolsista?

Turno 71: [Mediador N1]: Humm... (Pausa). Ah, eu diria que ele... Que ele... Ele tem o comprometimento devido, adequado de todo monitor, mas eu acho que ele não queria muitas responsabilidades... Perante a EB. É... Eu acho que ele teria... Queria fazer outras coisas também ne. Não ficar tão, tão atolado em cargas ne. E ele também tá... É do integral. Tudo bem, o mediador N2 também é do integral, mas... Se eu fosse do integral, eu pensaria duas vezes antes de ser um bolsista. É... Eu sou do noturno no caso. Então, eu acho que ele tem as prioridades dele ne.

Turno 72: [Entrevistador]: Entendi. É... Você acredita que a EB possa ajudar na sua formação profissional?

Turno 73: [Mediador N1]: Nossa, muito.

Turno 74: [Entrevistador]: Por quê?

Turno 75: [Mediador N1]: Porque se eu for seguir a área da licenciatura... (pausa. Telefone tocou). Continua ne?

Turno 76: [Entrevistador]: Continua, até porque aqui também tá gravando.

Turno 77: [Mediador N1]: Qual é a pergunta mesmo?

Turno 78: [Entrevistador]: Se você acredita que a EB possa te ajudar na formação profissional e por quê? 
Turno 79: [Mediador N1]: Sim, muito. Se eu seguir a área de pesquisador, eu vou ter que dar aula e eu dando aula, eu vou ter uma aula de qualidade...

Turno 80: [Entrevistador]: Por que você vai dar aula?

Turno 81: [Mediador N1]: Porque pesquisador dá aula.

Turno 82: [Entrevistador]: Dá aula em universidade, entendi.

Turno 83: [Mediador N1]: Sim, aham. E... Quando eu for dar aula, eu vou ter uma carga de aula comum com possíveis atividades que eu possa dar (risos). Eu vou ter um acúmulo de possibilidades de dar aula. Ter a didática um pouco mais avançada. E... Ainda como pesquisador é... A gente vai participar de simpósios, eu vou ter que escrever textos ne. Escrever papers e... Isso vai me ajudar a passar informação adiante, nos simpósios e na produção do próprio texto. E quem sabe, trabalhar com pesquisa na educação também ne. E... Beleza. E se eu for só seguir a licenciatura e dar aula, não precisa nem falar (risos). Não precisa nem falar. Eu diria que eu já vou ter... Se um dia eu for dar aula de fisiologia eu já sei o que eu vou fazer. O que eu faço sempre ne. Se eu for dar aula de genética, poxa, escoisos. Não precisa nem pensar. Já tá lá ne. Então, isso vai me ajudar muito assim. Eu queria trabalhar também, quem sabe, na produção de livro didático. De material didático ne. E... Também, vai me ajudar muito assim, a saber quais são as dificuldades maiores das pessoas e quais são as metodologias, a linguagem melhor, a linguagem melhor para falar determinado assunto.

Turno 84: [Entrevistador]: Você já entrou na biologia querendo ser professor ou foi depois que entrou na $E B$ ?

Turno 85: [Mediador N1]: Não. Assim. Não necessariamente. Eu tava com o leque aberto não descartava a hipótese de ser professor. Mas eu entrei mais na biologia pra... Por causa da ecologia. Mas por causa disso. Acho que a essência da ideia é adaptar o homem ao ciclo, mas isso ai é muito filosófico (risos). Mas é ecologia.

Turno 86: [Entrevistador]: Gosta de trabalhar como mediador e pretende continuar nessa área? Vamos supor que você seja convidado pro Instituto Butantã, por exemplo.

Turno 87: [Mediador N1]: Eu queria trabalhar em outros, em outras mediações pra, pra ver se eu, se eu não fico só nessa... A EB ela é uma mediação... (Interrompido pelo telefone). A EB ela é uma mediação só que talvez eu esteja muito viciado no tipo de mediação da EB ne. Talvez trabalhar num museu, trabalhar no Instituto Butantã, talvez seja outra pegada de mediação. E eu sempre gostei de mediação também, enfim. Eu fazia, no cursinho, eu fiz um grupo de discussões assim. 
Turno 88: [Entrevistador]: Ah, que legal.

Turno 89: [Mediador N1]: Toda quinta-feira a gente discutia e eu mediava, sabe. Ah, sei lá. Eu gosto. Eu sou meio filosófico, besta (risos). Mas eu gosto da mediação.

Turno 90: [Entrevistador]: E pra terminar, você participa ou pretende participar da elaboração das atividades da EB?

Turno 91: [Mediador N1]: Participo bastante e... Se eu participo, então, quer dizer que eu pretendo (risos). Participo bastante. A gente tá fazendo uma fisio agora de três horas ne. A gente faz, normalmente, uma hora e meia.

Turno 92: [Entrevistador]: Uma hora e meia.

Turno 93: [Mediador N1]: Que vai ter audição que a gente não tem, por exemplo. E tô participando de uma de lixo também, de... Dessa do descarte e de repensar sobre o consumo de lixo. Lixo orgânico e inorgânico, reciclagem e... Eu pretendo sim, fazer novas atividades e eu quero encher aquele site de atividades e atividades boas, ne. Porque, às vezes, a gente sempre fica naquelas: trilha da biodiversidade, escoisos e fisiologia. Meu vamos além. Vamos colocar ecologia também. Fazer umas coisas diferentes. Falta... Faltam algumas áreas da biologia que tem carros chefes ne, na EB. Então, eu acho que eu pretendo fazer isso.

Turno 94: [Entrevistador]: Legal.

Turno 95: [Mediador N1]: Em criação de atividades.

Turno 96: [Entrevistador]: Legal. Tem alguma coisa que você queira acrescentar?

Turno 97: [Mediador N1]: Humm... Ah, não sei. Acho que eu falei tudo.

Turno 98: [Entrevistador]: Então tá. Obrigada. Desculpa (pelas interrupções).

São Paulo, 20 de Setembro de 2013.

\section{2a Entrevista com mediador Novato 2 (N2) da Estação Biologia.}

Turno 1: [Entrevistador]: Quanto tempo você está na EB?

Turno 2: [Mediador N2]: É... tô desde o começo de 2012, então, são dois anos quase.

Turno 3: [Entrevistador]: Vai fazer dois anos. Por que você decidiu entrar na EB?

Turno 4: [Mediador N2]: Ah, eu decidi entrar na EB porque desde que eu, primeiro, que eu fiquei sabendo que ela existia. Que foi através do manual que você ganha na matrícula, o manual dos bichos que descrevia rapidamente todas as entidades da Bio e eu achei que foi a que mais tinha a ver comigo, porque nem sei, assim, dizer exatamente porque... Não sei se foi a pegada educacional que me puxou porque nunca foi certeza pra mim que eu queria fazer 
isso. Sei lá era só um assunto que me interessava. Não sei. Acho que foi a que eu olhei e falei "ah, eu quero participar disso ai. Achei legal". Entendeu? Me atraiu assim acho que pelo fato de ter o contato com o público é... Acho que foi isso. Acho que foi o contato com o público. Não exatamente por ser num ambiente... Numa... Num âmbito escolar, entende? Acho que... Receber pessoas e... Talvez o negócio da responsabilidade, por querer cuidar do espaço e tudo mais.

Turno 5: [Entrevistador]: E por que você decidiu continuar na EB?

Turno 6: [Mediador N2]: Então, porque eu fui me envolvendo muito, assim, e eu senti que eu estava fazendo parte daquilo e que eu tava gostando do resultado. Eu gosto de ver a EB andar. Eu gosto de ver as coisas acontecendo e você pegar um projeto novo pra fazer e montar atividade e aplicar e ver que ela dá certo, sabe? Acho que é... É por isso, assim. É por ver que você investe o seu tempo e sua energia e o negócio dá certo assim. O negócio sai.

Turno 7: [Entrevistador]: Junto com você entraram muitas pessoas.

Turno 8: [Mediador N2]: Uhum.

Turno 9: [Entrevistador]: Por que você acha que... Bem, eu tava conversando com outro mediador e ele falou que acha que mais da metade saiu, ne?

Turno 10: [Mediador N2]: Uhum. É.

Turno 11: [Entrevistador]: Por que, na sua opinião, por que você acha que essas pessoas saíram?

Turno 12: [Mediador N2]: Ah, porque eu acho que assim, quando você entra na faculdade é o momento de você falar "vou participar desse monte de coisa ai, ne?". É... Tem muita novidade, muitas coisas que você pode fazer e muita gente acaba se envolvendo com várias coisas, mas não é uma coisa fácil. Não é uma coisa óbvia vir aqui sabe. Eu acabo levando muita coisa pra fazer em casa e eu fico pensando, entendeu? Eu acho que vai muito além de você participar de uma comissão e fazer suas manutenções por mês. Se você tá fazendo direito. E depois de um tempo, a coisa acaba ficando meio maçante, se é só isso que... Se você tá aqui só pra fazer isso. Se você tá aqui pra participar de uma visita, ficar costurando cromossomo (risos), entendeu? Ou varrendo a sala. Sei lá. Porque você tem que mudar a sua função aqui. Você tem que ir descobrindo novas coisas pra fazer. Sempre tem coisa pra fazer, mas se você fica no óbvio, fica chato. Então, eu acho que tem muita gente que sai por causa disso. Porque, assim, acaba cansando do que já tava fazendo há muito tempo. E... Eu acho que tem gente que só assim, não é isso, sabe, que a pessoa quer fazer. É... Acho que um misto ne. Porque se você se interessa muito você vai acabar se envolvendo com outras coisas e não vai 
ficar entediante, mas... É... Eu acho que a EB, ela acaba sendo muito diferente do que você imagina no final das contas. Tem muita gente que entra assim pra fazer folia sabe (risos). Tem, eu acho que é ok também, entendeu? Acho que a EB também se constrói disso, assim. De pessoas muito amigas e tal. Mas ai tem uma hora que você fala "ah, tá né. Não vou ficar aqui pra ficar com meus amigos. Se for assim, eu fico lá no CA também e tudo bem". Então, eu acho que tem muita gente que sai por causa disso assim. Por se dar conta do que é e por cansar um pouco. É... Acho que essa é a massa assim.

Turno 13: [Entrevistador]: O que é a EB?

Turno 14: [Mediador N2]: Então, é difícil definir (risos). Normalmente, quando alguém me pergunta eu sempre falo o básico assim: "ah é um projeto de extensão, a gente recebe umas escolas e faz visita com eles e monta as nossas próprias atividades assim". Mas... Ah... Eu acho que... Eu como um... Espaço pra você criar e aprender assim. É um espaço de troca muito rico, assim. E... Ah... Que difícil (risos). É eu acho que assim... No final das contas não dá pra fugir muito dos objetivos da EB, sabe, porque é isso assim. Tá ali na raiz da coisa. Então, é... Criar, como fala? Formar monitores, ne. Afinal de contas, a gente muda muito assim. Eu vejo que eu mudei muito desde que eu entrei até agora. E... Sei lá. Formar... Trocar com o público assim, sabe. Através dessas atividades ne, e bolar atividades novas, passar esse conhecimento. Eu lembro que quando você me perguntou, você até falou assim: "você acha que o objetivo principal da EB é qual? É formar os monitores ou é receber visitas?" E eu acho, eu continuo achando assim, que é formar monitores, entendeu. Porque... Claro que é muito importante uma criança que tá na escola pública e nunca tem laboratório, nunca viu nada. Ai ela vem aqui vê um bicho vivo, um bicho no álcool. Pode pegar. É uma experiência pra vida e tudo mais. Acho que é muito importante, mas... Você entende o que eu quero dizer?

Turno 15: [Entrevistador]: Sim

Turno 16: [Mediador N2]: Tipo, a gente tá aqui, daí a gente vai pra fora, algum dia.

Turno 17: [Entrevistador]: Claro.

Turno 18: [Mediador N2]: E com isso, a gente vai levar essa experiência com a gente. Pelo menos, é isso que eu gostaria. Então, acho que é isso. É um espaço de formação, espaço de troca e... É... (risos).

Turno 19: [Entrevistador]: Qual a sua função na EB agora?

Turno 20: [Mediador N2]: Então, agora eu tô como bolsista né, e ai eu fiquei com o departamento assim. É porque a gente dividiu mais ou menos assim. Não quer dizer que você só faz isso ou que outras pessoas não podem fazer a função do seu departamento também. É... 
Mas eu fiquei com o departamento de coordenadoria pedagógica assim. Então seria mais ou menos o que a pessoa que incentiva o pessoal a produzir novas atividades e ver onde que elas estão ne. Pra não acontecer de uma atividade ficar no limbo. É... Começar fazer e depois todo mundo desistir porque não era uma ideia tão boa assim. Então, saber encaminhar isso ne.

Turno 21: [Entrevistador]: Uhum.

Turno 22: [Mediador N2]: É basicamente essa a minha função.

Turno 23: [Entrevistador]: Na turma anterior, assim, em que vocês eram novatos e tinha os veteranos ne, eles identificavam o mediador V2 como o centro. E na de vocês? Quem é o centro?

Turno 24: [Mediador N2]: Ai... Então, eu acho que assim. Agora a gente tá passando por uma crise, assim. Não sei se isso apareceu na entrevista do mediador N1, mas eu vejo que a EB tá numa ligeira crise aqui. Porque o mediador V2 saiu. Nesse semestre ele não tá mais aqui. Ele ainda é da EB, mas ele não é mais bolsista. Então, a atuação dele caiu mais do que pela metade, porque ele tava muito envolvido e agora ele tem outras coisas ali ne. Cada um tem o seu ciclo e tal. E eu acho que a gente ficou um pouco órfão disso, porque a gente tava muito... Tava tudo muito polarizado nele realmente. E agora a gente tem que aprender a lidar com isso, entendeu? Então, eu acho que, assim, no final das contas as coisas recaíram mais sobre o mediador $\mathrm{C}$ e sobre eu e o mediador N1 também. Acho que vai ser uma coisa meio ai de a gente saber (risos) é... Articular isso e fazer o trabalho que o mediador V2 fazia, entendeu? É difícil, porque não é uma coisa assim de você ler num protocolo "ah, você faz assim", sabe. Não é uma coisa tipo, "ah, você tem que saber o que a mitocôndria faz e saber explicar ali na frente" entendeu? É uma coisa muito mais articulada, de o pessoal te conhecer aqui no instituto de... Saber falar com todo mundo e onde você tem que ir se acontece uma... Um abacaxi do nada (risos), entendeu? Então, é difícil. Mas você perguntou em quem que tava né?

Turno 25: [Entrevistador]: É, não precisa ser uma pessoa específica.

Turno 26: [Mediador N2]: É, não, eu acho que é meio isso assim. Tipo, acho que tá mais no mediador C. Se eu fosse dizer assim, acho que tá mais no mediador C. Porque afinal de contas ele tá aqui há mais tempo ne. Há um ano a mais que a gente. É isso.

Turno 27: [Entrevistador]: Tá ótimo. Com que frequência você vem a EB?

Turno 28: [Mediador N2]: Nossa, acho que eu venho todo dia. Assim, deixa eu ver. Acho que quatro vezes por semana assim. Se eu não venho cinco sabe (risos). Não tem um dia que 
eu não venho porque você tá aqui se tem aula, você passa na EB pra ver se tá tudo certo. Eu venho sempre.

Turno 29: [Entrevistador]: Tá ótimo. É... Você já deve ter participado de várias visitas?

Turno 30: [Mediador N2]: Uhum

Turno 31: [Entrevistador]: Tem alguma experiência que te marcou? Que você gostaria de comentar?

Turno 32: [Mediador N2]: Humm... Deixa eu ver. Ah, eu acho que tem umas visitas assim, visitas muito boas e visitas muito difíceis também que, às vezes, ficam marcadas né. Não sei se eu tenho uma específica pra dizer, mas... Ah, normalmente assim, visita com... De trilha da biodiversidade, que apesar de ser justamente o que a gente mais faz, acho que é sempre que aparece as coisas mais legais, assim, ne? Por que, às vezes, eu fico pensando que evolução é um assunto que você pode ficar falando eternidades. Porque tem muito erro de conceito e também elas falam muitas coisas legais e... Eu gosto de ouvir, sabe, o que elas tem a dizer. E... Assim, aparece muito erro de conceito. Eu ouço assim quando você pergunta o que é evolução, sabe. Eu gosto de ouvir isso, eu gosto desse retorno. Humm... Perguntas difíceis. deixa eu pensar (risos). Não sei. Eu acho que eu tenho que aprender muito, assim, sobre lidar com, com grandes... Tipo, muita quantidade de criança e aquelas que... Mais difíceis de prender a atenção, ne. Porque, sei lá, o que a gente mais sabe ser é estudante. Eu fui estudante a minha vida inteira. E eu posso citar inúmeros professores que eu achei ruins e são muito poucos os nomes, eu consigo contar nos dedos aqueles que realmente fizeram... Realmente me prenderam atenção, que eu consegui... Que eu consegui aprender mais e tipo passa a mais que um professor sabe, assim. Você respeita a pessoa, então você tá ali ouvindo ela e tal. Então é muito difícil você saber fazer isso. É claro que a gente não é professor aqui, mas é que eu sempre me pergunto sabe. Você tá ali na frente e ai sabe. Qual a moral que você vai ter de tipo, prender a atenção deles pra passar algum assunto, às vezes. Eles não... Quem é você sabe? (risos). Então, assim, é difícil achar esse... Essa dosagem assim. Acho que é nesse sentido que eu acho mais difícil de fazer visita às vezes. Conseguir prender a atenção e ser leve, sabe. De ser leve com a classe, mas sem cair numa coisa boba, entendeu? E... É bem isso assim.

Turno 33: [Entrevistador]: Tá ótimo. Qual atividade que você mais gosta da EB?

Turno 34: [Mediador N2]: Hum... Tá é... Acho que...

Turno 35: [Entrevistador]: Ou que costuma apresentar? 
Turno 36: [Mediador N2]: Tá. Então, é uma coisa que é assim engraçada. Eu acho que eu tenho uma tendência sempre de, quando eu coloco... Me ploto pras visitas eu reparo que minha tendência é sempre eu colocar pras coisas de introdução assim, sabe. Eu gosto sempre de introduzir as atividades. Tipo, dar oi pra eles, receber eles, introduzir e dar tchau. É tipo, isso é o que eu mais gosto de fazer entendeu? Não sei porque. Eu acho que eu gosto assim dessa coisa tipo chamar atenção e dai um up e colocar no caminho que eu quero. Entendeu? Mas, acho que a atividade que eu mais gosto, que eu acho mais redondinha, assim, a mais legal é a dos escoisos né. Do de genética. Inclusive agora mudou de nome viu? No nosso site tá chamando laboratório da genética.

Turno 37: [Entrevistador]: Ah, eu vi.

Turno 38: [Mediador N2]: É então. É porque a gente tava achando esse nome meio estranho (risos). Acho que essa atividade é que eu mais gosto porque ela consegue falar sobre coisas muito importante assim, ah... É muito palpável mesmo ne. Aposto que eu respondi a mesma coisa ne? Você me perguntou isso, eu respondi a mesma coisa no ano passado? Eu não lembro.

Turno 39: [Entrevistador]: Eu não vou lembrar agora também (risos).

Turno 40: [Mediador N2]: É... Ah, é muito legal aquilo assim. É muito bem pensado e daí sabe, eles colocarem ali, montarem um cachorro dá uma carinho pessoal. Os alunos eles estão mais interessados naquilo, sabe? Tipo o meu cachorrinho. Ai eles vão lá na frente e mostram. Eu acho que das melhores assim que a gente tem realmente. É... Mas ai, tem aquela coisa. Tem uma angustia assim. Porque eu acho que a EB tá muito tempo sem atividades novas, entendeu? E ai você acaba ficando naquela, naquela angustia mesmo de fazer sempre essa mesma coisa e ficar muito atrelado aquilo que já tá pronto há muito tempo. Você não fez parte da construção daquela atividade. Eu cheguei aqui, as três atividades que mais saem que é fisiologia, os escoisos e biodiversidade, desde que eu entrei já existe. Já existe há muito tempo, então, eu acho que, às vezes, você não tá pegando com as duas mãos assim. Agora a gente tá editando ne, a atividade de fisiologia, o mediador N1 que tá encabeçando isso. Então, tem uma porção de coisas novas lá, eu acho que isso vai ser bom pra dar uma... Uma refrescada na coisa. É... Ah, tem outras que eu gosto também. Assim.

Turno 41: [Entrevistador]: Nessa que você gosta de genética, de escoisos, você mudaria alguma coisa?

Turno 42: [Mediador N2]: Hum.... Não sei. Talvez a introdução dela, mas eu não tenho uma sugestão assim. Só porque a introdução é mais teórica na frente ai eu vejo que, às vezes, puxa 
a classe um pouco pra baixo. E, principalmente, se eles não tiveram genética. Mas ai eu acho que é uma coisa complicada, você falar de genética numa classe que não teve, sendo que você não é professora, não é sua função passar esse assunto pela primeira vez. Então, é... Acho que se eu fosse mudar seria no começo. Mas não que eu tenha uma sugestão.

Turno 43: [Entrevistador]: Já falou dos objetivos ne. Pra você, pontos fortes e fracos da EB?

Turno44: [Mediador N2]: Tá. Acho que ponto forte da EB. Humm... Eu acho que autonomia é um ponto forte porque se a gente ficasse o tempo inteiro, assim, muito atrelado ao que o instituto quer ou ao que a professora disse e tudo mais, eu acho que a gente não sairia daqui tão apropriado do que a gente faz. Entende? É muito claro assim. Você percebe claramente quando alguém tá apropriado do projeto e não. Entendeu? Chega uma hora que você não fica mais esperando assim alguma coisa cair do céu, alguém pedir pra você fazer. Você tá fazendo. Entende? Você tá em casa no sábado as oito horas da noite abrindo e-mail da EB pra responder pra professora, pra mandar o negócio de você mandar. Entendeu? É uma coisa assim, de repente você percebe que você já tá ali no meio do olho do furacão. Então, eu acho que essa... E eu acho que isso em muito se deve ao fato de a gente não tá é... O tempo inteiro prestando contas sabe, pra Bia ne, que nossa coordenadora e tal. É... Mas ao mesmo tempo eu acho isso complicado, entendeu? Porque daí você acaba perdendo a mão, às vezes. Você acaba não sabendo se isso que você tá fazendo condiz com o que o instituto quer que você faça, entendeu. Porque você tá dentro dele. Você tem que fazer o que eles querem. Entendeu? Então, é uma dualidade que é difícil de medir assim. E... Inclusive muito da nossa crise se deve ao fato do mediador V2 ter saído e perdido um pouco essa comunicação entre a Bia entendeu? Então... Porque era ele que falava mais com ela. Ela quase não nos conhece, entendeu. Ai recentemente a gente acabou tendo que correr atrás disso, enfim... E ai você percebe que já era assim, sabe (risos). É tipo um caminho sem volta. Mas é um bom caminho sem volta, entendeu. Eu quero dizer que é legal assim. Eu gosto do comprometimento. Tá, outro ponto positivo da EB é... Ah, não pera. Muito difícil essa pergunta (risos).

Turno 45: [Entrevistador]: Pode pensar com calma.

Turno 46: [Mediador N2]: Tá bom. Ah, eu gosto do fato de as pessoas poderem entrar sem grandes exigências sabe. Você tá aqui porque você quer ne. Ou pelo menos assim deveria ser. Então, eu gosto disso. E gosto porque normalmente é um pessoal com muita garra assim. Você manda uma ideia e tá todo mundo já pirando na ideia e começa a complementar. Então, acho que isso é muito bom. E tudo gira em torno da mesma coisa, essa coisa de autogestão, assim. Então, na verdade a resposta é a mesma, sabe. Os pontos fortes e os pontos fracos eles 
meio que tão muito unidos assim. A raiz é a mesma, entendeu? É muito difícil se auto gerir, é muito fácil perder a mão quando você é... Você tem que cuidar de tudo, entendeu? E, eu acho que por isso também é muito importante que os monitores estejam super articulados, porque, uma das discussões que a gente tava tendo no começo da semana com o mediador V2 e com alguns bolsistas enfim, alguns monitores, é essa coisa assim: o monitor vai ficando mais velho, ele vai ficando mais por dentro de tudo, ele já sabe tudo como ele resolve e... Ninguém mais começa a contestar isso, entendeu? Porque ele é... Afinal de contas ele tá lá há cinco anos, sei lá há quatro, cinco anos, então ele deve tá falando coisa que é real, mas no final das contas é... Quem faz esse projeto são os... O pessoal que acabou de entrar, o pessoal do segundo ano, do terceiro, enfim, mas começa a se afastar e querendo ou não a graduação de puxa a atenção pra algumas coisas e muita gente sai nessa fase ne. O mediador V1 acabou de sair. Ontem foi a última visita dele, não sei se você sabe?

Turno 47: [Entrevistador]: O mediador N1 comentou comigo.

Turno 48: [Mediador N2]: Então. E é assim mesmo, então, eu acho que tem que saber ir passando essa função, sabe, tipo abrir mão do que... É que passou seu tempo e... E tô me perdendo, mas assim, dizer, é... Não deixar tudo isso na mão de uma pessoa só. Entendeu? Porque ai assim, porque fulano decidiu e ai se a ideia, na verdade, for assim nada a ver, se isso não condiz com que o pessoal acha, onde você tá colocando a EB, entendeu? Eu acho que tem que sempre rolar uma coisa assim, porque a gente tem que sempre lembrar que assim, já que a gente tá meio autogestão vamos ficar muito atento ao que a gente tá fazendo. O tempo inteiro sabe. Vamos nos perguntar: "será que é por ai? Será que a gente pode tomar essa decisão?". Entendeu? Porque senão a gente acaba ficando aqui, sabe, tá todo mundo ah, sempre aqui na $\mathrm{EB}$, todo mundo muito amigo, é todo mundo muito tranquilo, é tudo muito fácil, então, ah, dai a gente vê, a gente fez uma besteira enorme. Tipo isso.

Turno 49: [Entrevistador]: E você acha que quem tem essa noção de autogestão é quem está como bolsista?

Turno 50: [Mediador N2]: Não, acho que não. Eu acho que assim, os bolsistas, principalmente, deveriam é... Ter essa noção e ter autonomia, mas você vê muitos monitores que não são bolsistas...

Turno 51: [Entrevistador]: E que tem essa noção?

Turno 52: [Mediador N2]: É. Assim, bem, bem envolvidos. Acho que isso é bom também ne. Tipo não serem só os bolsistas que acaba ficando com aquela cara de chefe ne. Ah, ele recebe pra isso, então deixa que... 
Turno 53: [Entrevistador]: Tá. Então você acabou de falar dos pontos fortes e fracos da EB e de você. Quais são os pontos fortes que você enxerga em você que ajuda, que contribui ne, que você consegue contribuir na EB?

Turno 54: [Mediador N2]: Acho que eu sou muito... Ah, acho que eu levo a sério, entendeu? O que eu faço. Eu gosto de vir aqui, ficar zoando e ficar com meus amigos. Sei lá, meus amigos... Eu tenho amigos de fora da EB, mas eu tenho muitos amigos na EB sabe. Então. É uma relação super íntima aqui e tal. Mas acho que eu sei levar a sério. Na hora que precisa, entendeu. Inclusive eu falei no começo da comissão ne, desse ano, porque chegou uns bichos, eles nem te conhecem ne, e ai sempre ah, vem um bicho "é tão legal a EB, entrem na EB, não sei o que". E... Só que assim, eu falei: "oh gente, é o seguinte assim: eu sou o mediador N2, muito prazer. Eu sou exigente e, às vezes, eu vou virar pra vocês e vou falar assim, oh você fez isso e fez errado, tipo, tem que fazer de novo ou você tem que rever isso ai. Sabe. Fez besteira aqui e ali. Mas nunca é pessoal, não entenda que é pessoal. Eu tô falando porque eu reparei e eu não vou ficar quieta, entendeu?" Então, eu acho que isso assim. Eu não tenho dedo pra falar se alguém tá fazendo alguma coisa errada como função na EB, entendeu?

Turno 55: [Entrevistador]: Uhum.

Turno 56: [Mediador N2]: E ai beleza. Tipo, eu posso dar uma bronca e falar "vamos tomar um café". Entendeu? Então, eu acho que isso é bom. A seriedade é... Ah...

Turno 57: [Entrevistador]: O fato de você estar na... No que você falou do departamento de coordenadora pedagógica ne?

Turno 58: [Mediador N2]: É.

Turno 59: [Entrevistador]: Foi você quem quis ou te colocaram nessa função?

Turno 60: [Mediador N2]: Então, foi mais ou menos assim, a gente sentou todo mundo e falou "acho que são essas as principais funções dos bolsistas". A gente ficou discutindo quais eram as funções. E ai, foi meio por interesse. Quem tem interesse de fazer isso, quem tem interesse de fazer aquilo. É... E assim eu gosto muito dessa parte e tinha interesse em outras áreas também, mas foi assim por combinado mesmo.

Turno 61: [Entrevistador]: E você identifica algum ponto forte seu que ajude nessa área?

Turno 62: [Mediador N2]: É... Então, eu me interesso muito por essa área, entendeu? Eu tô morrendo de vontade de abrir a minha licenciatura, quando eu conseguir eu vou abrir. Mas assim... Acho que nesse sentido assim, eu tenho garra pra levar a parte pedagógica da EB pra frente. Que daí entra também "ah a EB é uma autogestão lá lá lá", mas ai ninguém aqui faz licenciatura, todo mundo na graduação e acha que vai pegar e fazer uma atividade que vai sair 
super bom e as pessoas estudam uma vida inteira pra fazer isso, entendeu? Então, tá vendo? Tudo gira em torno da mesma coisa. Assim, da mesma forma que é muito legal porque a gente faz isso. Tem um monte de problemas porque a gente não tá preparado pra lidar com situações e com lidar com criança, lidar com o ensino. E... Ah... É difícil conseguir material, é difícil conseguir que alguém troque a lâmpada sabe? Então, são essas coisas que me pegam um pouco na EB assim. Que... Não pode deixar isso te puxar pra baixo, do tipo "ai que difícil sabe, tem que ir lá falar com o instituto porque a tomada não tá funcionando e tipo, tem que pegar e tipo, mas é legal, vou lá" (risos). Mas é sobre a coordenadoria, tanto o fato de eu gostar muito dessa parte de pedagogia é... De eu ser exigente, de eu ser comprometida e... Eu gosto de lidar com o público. Entendeu? É por isso que eu tô aqui. É porque eu gosto de receber as pessoas, porque eu gosto de falar com elas, então, essa coisa de eu saber fazer a abordagem entendeu?

Turno 63: [Entrevistador]: Entendi.

Turno 64: [Mediador N2]: É isso assim. Acho que é... É uma coisa que eu acho muito importante porque você vai começar uma visita, se você começa ela mal, por mais que você tente salvar ela depois, pode ser que esteja perdida, entendeu? Entrou alguém aqui com uma cara de sono e falou tipo "ah, então tá, vamos lá". Pronto! Agora a menina que tem 17 anos e não tá nem ai pra nada tipo ela não vai mais te dar moral, entendeu? Então eu acho essa parte importante assim. Ai eu ficaria com outras partes, outras funções na EB também, sabe. Eu ficaria na função de divulgação, ficaria na função mais de RH e... Não sei (risos). Não sei o que é tão forte que me prende lá, entendeu? Acho que foi assim, gosto e faria outras coisas também.

Turno 65: [Entrevistador]: Entendi.

Turno 66: [Mediador N2]: Por enquanto ainda não tô ferrenha numa coisa só, defendendo que eu quero ficar lá. E eu espero que nunca ne, porque o mediador V1 até falou quando ele saiu. Ele falou isso, inclusive que eu falei mais cedo, de você nunca se prender a uma função só. Ele falou que ele entrou, ai primeiro ele tava mais pirando nas plantas e não sei o que e foi aprender tudo as suculentas e sobre as carnívoras pra apresentar na visita ai depois ele queria montar atividade, dai depois é... Cansou disso. Queria aprender as coisas burocráticas, a lidar com o instituto e dai não agora eu quero fazer o papo pedagógico, ne. Não sei se você chegou a vir em algum?

Turno 67: [Entrevistador]: Eu vim em dois. 
Turno 68: [Mediador N2]: Então, sabe, então ele foi mudando assim e não é a toa que ele ficou tanto tempo sabe? É isso, de primeiro ele tava envolvido e ai ele foi se envolvendo com coisas diferentes, por isso que deu certo. Se não você fica batendo sempre na mesma tecla ne. E ai fica veteranossauro chato assim (risos).

Turno 69: [Entrevistador]: E pontos fortes do mediador N3? O que você enxerga de pontos fortes dele?

Turno 70: [Mediador N2]: Hum... Deixa eu ver. É.. Ai é muito difícil responder essa pergunta, acho que eu não conheço ela tão bem. É...

Turno 71: [Entrevistador]: Então, me responda o seguinte: por que que você e o mediador N1 viraram bolsistas e ela não, sendo que vocês entraram na mesma época?

Turno 72: [Mediador N2]: Tá. Então, eu acho que é por causa do envolvimento entendeu? É que nem eu te falei, eu venho aqui cinco vezes por semana, semestre passado eu não era bolsista e parecia que eu estava fazendo duas comissões. Acho que você vai ganhando assim o envolvimento. E ele... Ele decidiu não, entendeu? Acho que foi isso. Ele optou por fazer parte da $\mathrm{EB}$, mas de uma outra maneira, com certeza uma maneira muito diferente da que eu e o mediador N1 fazemos parte. Nem por isso é menos válida, entendeu? A gente precisa de todo tipo de gente aqui. A gente não precisa que todo mundo é... Enfim, esteja o tempo inteiro pensando se fulano se plotou na secretaria, desde que ne, a pessoa esteja envolvida com o que ela se propôs a fazer ali, eu acho que tá bom. O que eu não gosto é de gente que fala assim: "ah, beleza, eu apareço lá" e dai x. A gente nunca mais vê e vai ou não vai, não dá desculpas e tal. Mas acho que foi bem isso. Ela escolheu não se envolver tanto. E é muito diferente. $\mathrm{O}$ mediador N1 e eu, a gente tem características muito semelhantes, assim, no modo de agir assim. Você vê na visita, ai sabe ele é muito tio da visita, mas às vezes eu também sou tio da visita. O mediador N3, por exemplo, nunca assim. Acho que eu nunca vi ela apresentando uma coisa lá na frente. Entendeu, ela é diferente assim. A postura dela. Ela gosta de estar em grupos pequenos, apresentar os esqueletos, apresentar o bicho-pau. É onde ela se sente mais a vontade, entendeu?

Turno 73: [Entrevistador]: Uhum.

Turno 74: [Mediador N2]: Que nem eu te falei, eu não curto tanto. Eu apresento o bicho-pau, beleza, eu gosto de apresentar o bicho-pau, mas o que eu gosto mesmo é de tipo receber e tipo ouvir de todo mundo e estar ali com... Aqui, entendeu? Eu gosto de estar aqui. Sei lá. Não sei se é porque eu me acho enfim (risos), mas eu gosto, entendeu? Eu gosto de um público, sei lá. 
Turno 75: [Entrevistador]: E pontos fortes do mediador N1?

Turno 76: [Mediador N2]: Então, eu acho eu ele lida super bem com a turma. As pessoas gostam dele. Eu não sei o que é. Ele entra aqui, ele dá oi e ai você sempre ouvi assim, sempre nas visitas eu ouço: "ah, eu gostei do mediador N1". Ou as meninas ficam meio "ah ele passou o facebook". Sei lá. Ele chama atenção, entendeu? Ele consegue prender a atenção. É... Isso é muito claro. Isso é muito importante. Tipo, eu vejo muita gente aqui na frente, a pessoa tá falando alto, a pessoa tá falando claro ne, mas ela não consegue passar uma ideia de uma maneira que fique compreensível, entendeu? São pequenos detalhes e que é... Ai, eu fico... Tento prestar muita atenção nisso. Me fazer entender sabe. Se você não se faz entender, não dá. Tipo, você precisa desde o começo, você precisa ter uma linguagem clara. Você precisa ter uma dicção clara. A sua voz tem que estar atingindo todo mundo, tudo mais. Acho que isso dai vem muito, porque eu sou... Eu fiz teatro ai eu piro nesse assunto. Adoro. E ai você vê muita gente aqui explicando e tem gente que tá olhando pela janela já. Não culpo. Olha como é lindo, sabe. E... São pequenas coisas do tipo faz uma pergunta: "ah, quem sabe o que é tal coisa?", ai alguém aqui vira e fala assim: "ah, eu sei. É isso e aquilo. Sabe. Eu sei o que é evolução. É isso". Dai em vez de você falar assim: "pois é, a evolução é como ele disse isso e aquilo", fala assim: "isso tá certo" e continua a explicação, entendeu? Esse tipo de coisa vai perdendo um pouco da atenção assim. E eu acho que o mediador N1 sabe fazer isso muito bem. Ele sabe explicar do começo ao fim. E não deixar as coisas sem amarrar. Você tem estar sempre amarrando tudo. Não pode abrir um monte de questão e dai ok fim. Entendeu?

Turno 77: [Entrevistador]: Entendi. Acredita que a EB possa ajudar na sua formação profissional?

Turno 78: [Mediador N2]: Ah, com certeza ne. Acho que já ajudou bastante.

Turno 79: [Entrevistador]: Deixa eu só colocar ali (referindo-se ao computador) para ele não morrer total?

Turno 80: [Mediador N2]: Ah, tudo bem. Você quer que eu troque de mesa? Eu vou pegar o gravador ta?

Turno 81: [Entrevistador]: Bem, então, é se a EB te... Se você acha que a EB te ajuda na formação profissional e por quê?

Turno 82: [Mediador N2]: Então, acho que muito porque tem a parte prática que você não pode deixar de lado ne. Eu não sei o que eu quero fazer da minha vida, mas assim, acho que fica meio na cara quando se começa pensar a respeito que eu quero mexer com pessoas ne. Que eu quero tipo... Tá sempre me comunicando ou passando alguma coisa, recebendo o 
público e tal. Então, eu penso em ser, talvez professora ou trabalhar em museu. É... E eu acho que tem um ganho de experiência assim prática muito grande. Sabe, são esses: "ah, eu não sei". É muito você tem que saber adequar a sua linguagem à idade que você tá recebendo e se eles não estão prestando atenção, você tem que dar um jeito de eles começarem a prestar atenção. É porque você tá fazendo a coisa de um jeito que não saiu legal ali, entendeu? Não funcionou com essa turma. Cada turma é uma. Dai você tem que ver se você fala de um jeito diferente, se você chama atenção de um ou chama atenção da classe, faz uma brincadeira ou não. Tá precisando de um pulso firme, sabe. Eu acho que essas coisas você só aprende fazendo. E... Mas não só nesse sentido ne. Também na parte burocrática ai de... É... Tá ligado do que você precisa pro projeto continuar em frente, coisas muito básicas, entendeu? Que não é só você vir aqui e marcar sua visita direitinho. Você... Tem que estar tudo nos conformes. Uma coisa que pode parecer mais chata, mas que alguém tem que fazer e ai você pega e faz e fala: "nossa, oh que bom. Alguém tem que resolver, vou eu então". Sei lá. Ou vai o mediador N1, enfim. É... eu acho que é isso assim. Ai, fica meio igual ne? Isso eu já falei, mas é isso assim (risos). Acho que pela... Pela experiência de você saber ter jogo de cintura e de você ter a... Não é coragem assim a palavra é... De ter o pulso de falar assim "ah, vou lá, vou fazer, eu cuido disso, vou correr atrás". Não faço ideia de que precisa do termo não sei qual pra poder ser... Pra poder receber a visita, não sei qual é, eu vou atrás, vou procurar. Um exemplo x, enfim.

Turno 83: [Entrevistador]: Tá ótimo. Bem, acho que você já respondeu as outras duas que é se você gosta de trabalhar como mediador e pretende continuar trabalhando na área, de repente ir pra um museu ne, um Instituto Butantã, não sei, e se você pretende trabalhar na elaboração de atividade. Como você tá como coordenadora pedagógica ne (risos).

Turno 84: [Mediador N2]: É então, mas assim, eu acho que... Acho que muito provavelmente eu vou acabar indo pra esse lado, mas eu fico sempre pensando ne. Sempre fico repensando o que eu quero. E mesmo que eu não vá fazer nada disso, sabe. Mesmo que eu não vá nem trabalhar com biologia e nem trabalhar com... Em museu, professora, eu acho que ainda assim você leva experiência sabe. Porque... Porque no final das contas é tudo... É muito a ver com o modo como você se relaciona na vida, entendeu? Se você tem uma boa relação aqui com seu... Com os monitores, com a visita que chega, sabe, saber fazer uma brincadeira e não ser desrespeitoso, saber lidar com a professora de uma maneira tipo prática, entendeu. Você leva isso pra vida. Você tá ai fora, você tá se relacionando com as pessoas o tempo inteiro. Então é 
isso. Eu não sei o que quero fazer, mas com certeza a EB vai me ajudar. Eu gosto muito daqui.

Turno 85: [Entrevistador]: Bom, você quer completar alguma coisa com o que não foi falado?

Turno 86: [Mediador N2]: Acho que não. Você tem alguma outra pergunta?

Turno 87: [Entrevistador]: Então, é só isso mesmo.

Turno 88: [Mediador N2]: Então tá bom.

Turno 89: [Entrevistador]: Muito obrigada.

São Paulo, 04 de Novembro de 2013.

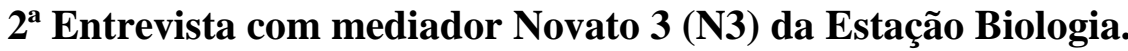

Turno 1: [Entrevistador]: Quanto tempo você tá na EB?

Turno 2: [Mediador N3]: Vai fazer dois anos.

Turno 3: [Entrevistador]: Dois anos.

Turno 4: [Mediador N3]: Isso.

Turno 5: [Entrevistador]: E por que que decidiu ficar? Por que decidiu entrar e por que decidiu ficar?

Turno 6: [Mediador N3]: Eu decidi entrar porque achei um projeto muito legal e eu queria melhorar a minha habilidade de falar com o público. E eu decidi ficar porque eu gostei muito da EB ne, tanto do modo como ela funciona, como também das pessoas que convivem aqui. Então, eu acho que eu tenho muito a melhorar, não só a EB, como eu também. Então, eu gosto daqui, pretendo ficar mais tempo (risos).

Turno 7: [Entrevistador]: Legal. E... Qual sua função na EB?

Turno 8: [Mediador N3]: Eu sou monitora. Eu não sou bolsista.

Turno 9: [Entrevistador]: E o que um monitor faz na EB?

Turno 10: [Mediador N3]: Ah, a gente tem que manter a entidade. A gente faz a conservação dela, cuida dela, cuida dos materiais que a gente tem aqui. Além de fazer as próprias visitas.

Turno 11: [Entrevistador]: Tá. E com que frequência você vem a EB?

Turno 12: [Mediador N3]: Uma vez por semana.

Turno 13: [Entrevistador]: Uma vez por semana. De quantas... Isso não dá pra responder, mas tem alguma visita que te marcou, alguma coisa que fica bem marcada assim das visitas? 
Turno 14: [Mediador N3]: Sempre tem as visitas que te marcam mais. Não por um todo, mas são por um ou dois alunos que te marcam mais. Não só com coisas boas, como com coisas ruins, às vezes. Às vezes, você encontra alunos que tem a mentalidade muito diferente da que você esperava. Isso pode ser bom, por exemplo, uma criança que já entende muito melhor das coisas do mundo do que você imaginaria assim pra idade dela. E isso eu acho interessante.

Turno 15: [Entrevistador]: Legal. E... Qual atividade que você mais gosta da EB?

Turno 16: [Mediador N3]: A trilha da biodiversidade.

Turno 17: [Entrevistador]: E... O que você costuma apresentar na trilha da biodiversidade?

Turno 18: [Mediador N3]: Eu apresentava muito o aquário, no entanto o aquário entrou em reforma e, então, eu passei a apresentar bastante os esqueletos.

Turno 19: [Entrevistador]: E é essa parte da apresentação do início da visita, você já fez alguma vez?

Turno 20: [Mediador N3]: A introdução da...

Turno 21: [Entrevistador]: É da visita, o início mesmo que eles falam das cinco áreas?

Turno 22: [Mediador N3]: Não.

Turno 23: [Entrevistador]: Não ne. E pra você, qual é o objetivo da EB?

Turno 24: [Mediador N3]: É retribuir um pouco daquilo que a gente recebe da sociedade. Como a gente sempre diz aqui. A gente recebe os impostos, então é uma forma de retribuir, além de mostrar um... Um lado diferente da biologia pros alunos ne. Porque na sala de aula eles têm muito daquela coisa de só matéria, só matéria e lousa ne. Às vezes, passa pro vídeo, mas é muito rara as vezes. E aqui você tem uma forma mais lúdica ne. Uma forma mais pegável assim da biologia. E... Geralmente, eles acabam gostando mais. Alunos que tem desempenho muitas vezes ruim na sala, as professoras falam que aqui eles mostram um conhecimento que elas não esperavam que eles tivessem. Devido ao... À forma como eles se comportam na sala de aula.

Turno 25: [Entrevistador]: No seu ponto de vista, quais são os pontos fortes e fracos da EB?

Turno 26: [Mediador N3]: Um ponto que eu acho forte e fraco ao mesmo tempo é que a EB é comandada pelos próprios alunos ne. Ela é direcionada pelos próprios alunos. Uma coisa boa disso é que ela ganha uma certa liberdade, de fazer as atividades e a gente acabou de sair do colégio, assim. Então, a gente tem uma ideia mais de aluno mesmo assim, do que se fosse uma coisa mais professor vendo isso. E... O ruim é que eu acho que, às vezes, a gente acaba se desorganizando um pouco, dispersa. São muitas ideias é... Não tem um centro assim do 
comando, então, eu acho importante ter um professor, que a gente tem professores ne, uma professora que coordena a EB. Coordena todas as cabecinhas aqui da EB pra uma direção.

Turno 27: [Entrevistador]: E em você? O que você enxerga de ponto forte que contribui pra EB?

Turno 28: [Mediador N3]: Humm... Ah, sei lá. Criatividade talvez um pouco e... Não sei. Gostar da EB.

Turno 29: [Entrevistador]: E do mediador N2? O que você enxerga de ponto forte dele?

Turno 30: [Mediador N3]: Ah, ele é bem entusiasmado, ele tem uma... Carisma. Ele consegue falar com voz alta assim, ele tem uma boa dicção e, acho que o fato de ele falar com tanta convicção assim acho que ajuda a pessoa a meio que... Entender as coisas. Seguir o que foi dito assim.

Turno 31: [Entrevistador]: E o mediador N1? O que você acha de ponto forte dele?

Turno 32: [Mediador N3]: Ele também é muito entusiasmado, ele é... Tem uma boa dicção também. Ele é empolgado pra fazer as coisas e, além do mais, ele é criativo também. Isso ajuda bastante.

Turno 33: [Entrevistador]: E... Acredita que a EB possa ajudar na sua formação profissional? Turno 34: [Mediador N3]: Sim.

Turno 35: [Entrevistador]: Por quê?

Turno 36: [Mediador N3]: Ah, é uma forma de você já ter contato com os alunos. Ver qual a realidade assim de estar na frente daquele monte de alunos, porque na faculdade você tem as matérias de licenciatura e você aprende como lidar com o aluno. Mas e se o aluno não agira da forma como você espera ne? Então, aqui é meio que já um... Um início assim desse contato e... É uma experiência.

Turno 37: [Entrevistador]: Legal. Gosta de trabalhar como mediador e pensa continuar nessa área? Ir pra um museu?

Turno 38: [Mediador N3]: Humm... Não penso pra vida inteira, mas como uma forma de experiência assim... Por um tempo pode ser interessante.

Turno 39: [Entrevistador]: Participa ou pretende participar da elaboração das atividades da $\mathrm{EB}$ ?

Turno 40: [Mediador N3]: Eu participo da elaboração de atividades. Eu participei da elaboração da fisio de três horas. 
Turno 41: [Entrevistador]: Legal. E... Tem alguma coisa que você queira acrescentar de como você começou na EB e como tá agora?

Turno 42: [Mediador N3]: É... Eu acho que é muito diferente quando você entra na EB, como bicho ne, como iniciante na EB, quando você tem um veterano ali pra te ajudar, pra te falar "ah, faz isso, isso e isso." e depois quando você é o veterano. Que ai não tem mais ninguém pra falar: "ah, faz isso." É você que tem que comandar todo aquele monte de aluno que tá novo ali confuso e você tem que dar um jeito de organizar eles assim.

Turno 43: [Entrevistador]: Como foi na formação? Você participou da formação dos seus calouros, dos seus bichos?

Turno 44: [Mediador N3]: Formação?

Turno 45: [Entrevistador]: Formação daqui da EB?

Turno 46: [Mediador N3]: Ah, ajudando eles?

Turno 47: [Entrevistador]: É isso.

Turno 48: [Mediador N3]: Hum... No começo, você vê que eles são bem dependentes de alguém pra comandar eles ne. Eles, às vezes ficam parados assim, e perguntam: "o que é pra fazer agora?" sabe. Tá as coisas na lousa, mas parece que eles têm um receio assim. Eles até mesmo não têm a iniciativa de colocar coisas na lousa. E... Agora, eu sinto que eles estão um pouco mais proativos assim. Tem a coisa na lousa, ninguém fez ele vai lá e... Pergunta: "ah, ninguém vai fazer, então eu vou fazer". É mais assim.

Turno 49: [Entrevistador]: E pra terminar, você enxerga algum centro da Estação Biologia? Alguma pessoa como centro ou algumas pessoas como centro da Estação Biologia?

Turno 50: [Mediador N3]: Bem, acho que os RDs sempre acabam sendo um centro assim, mesmo que eles tentem não ser, eles acabam sendo, porque são pessoas que estão mais inteiradas aqui dentro ne. Elas participam de duas comissões, elas fazem a parte burocrática daqui, então acaba ficando um pouco mais...

Turno 51: [Entrevistador]: Os RDs são os bolsistas?

Turno 52: [Mediador N3]: Isso.

Turno 53: [Entrevistador]: Ah, tá.

Turno 54: [Mediador N3]: Sem contar que os professores, os professores que comandam aqui que são a Bia e a Alê, elas também acabam sendo uma forma de centro assim pra EB. Porque elas é... Coordenam assim e tratam de partes burocráticas pra gente também. Elas são... Meio 
que a nossa consultoria. A gente pergunta as coisas pra elas, se a gente tá fazendo certo. Acho que é isso.

Turno 55: [Entrevistador]: Entendi. Tem alguma coisa que você queira acrescentar?

Turno 56: [Mediador N3]: Não. Acho que tá certo.

Turno 57: [Entrevistador]: Tá bom. Obrigada.

São Paulo, 04 de Novembro de 2013.

\section{2a Entrevista com mediador Novato 4 (N4) da Estação Biologia.}

Turno 1: [Entrevistador]: Quanto tempo você ficou na EB?

Turno 2: [Mediador N4]: Fiquei um ano e meio.

Turno 3: [Entrevistador]: E o que motivou permanecer por esse tempo?

Turno 4: [Mediador N4]: Ah, porque eu gostava do projeto em si ne. Da forma que todo mundo acredita, que a gente tem que passar o conhecimento na EB. Dessa maneira lúdica, dessa maneira mais é... Não sei. Mão na massa mesmo ne. Pegar as coisas, ver o material ou se não brincar com o "escoiso", eu acredito que isso é uma ótima forma de ensinar. E... Que o projeto na $\mathrm{EB}$, ele vale a pena por causa disso e, além disso, eu gostava, eu me divertia lá, me divertia ajudando pro projeto continuar é... Por exemplo, é... Até nas partes mais chatas ne, que a gente tinha que, às vezes, identificar uma vidraria, por exemplo, é... Pra falar, ah... Perguntavam assim: essa espécie de cobra, que espécie é essa? Até pra correr a chave e encontrar a espécie eu gostava. Sabe, de participar, de pensar é... Em atividades novas. Eu gostava do projeto como um todo, assim. Desde a parte de comissão até a parte de visita, eu gostava bem. Por isso eu fiquei tanto tempo.

Turno 5: [Entrevistador]: Legal. Qual era a função no momento da saída?

Turno 6: [Mediador N4]: Por que que eu sai?

Turno 7: [Entrevistador]: Não, sua função. Na época que você saiu?

Turno 8: [Mediador N4]: Eu era monitor.

Turno 9: [Entrevistador]: Monitor voluntário?

Turno 10: [Mediador N4]: Monitor voluntário isso.

Turno 11: [Entrevistador]: E com que frequência você vinha à EB?

Turno 12: [Mediador N4]: Quando eu sai?

Turno 13: [Entrevistador]: É.

Turno 14: [Mediador N4]: Hum... Uma, ah... Duas vezes por semana coloca ai. 
Turno 15: [Entrevistador]: Como voluntário você vinha duas vezes por semana?

Turno 16: [Mediador N4]: É. Não. Eu vinha na minha comissão ou visita, mas acabava vindo mais vezes na semana porque... Pra fazer uma coisa x ou só pra ficar lá e ajudar em alguma coisa.

Turno 17: [Entrevistador]: Teve alguma experiência de visita que te marcou?

Turno 18: [Mediador N4]: Humm.

Turno 19: [Entrevistador]: Alguma visita assim.

Turno 20: [Mediador N4]: Que ficou assim... Não uma visita em especial, mas foram coisas pontuais de visitas diferentes que ficou assim pra mim. Mas uma em especial assim não. Talvez uma que eu fiquei... Me deu nos nervos, que tinha um moleque muito pentelho (risos). Ai ficou marcada, mas no mau sentido assim (risos).

Turno 21: [Entrevistador]: Entendi. Qual atividade que você mais gostava de apresentar na EB?

Turno 22: [Mediador N4]: De apresentar... Ah... Eu acho que a trilha da biodiversidade. Eu acabei ajudando bastante, assim, na parte de montar uma das etapas dela, que a dos animais peçonhentos. É... E ai, no fundo ninguém queria apresentar aquilo, porque mexia com cobra, aranha e todo mundo tem medo, todo mundo tem asco e, no começo, ninguém achou que ia ser tão legal assim. Mas ai eu fui botando umas coisas de é... Profilaxia ne. Como o que reagir pra não ser picado por esses bichos. O que fazer se você for picado. Fui botando essas... E, além disso, eu falava do... Papel ecológico desses bichos ne. Que não adianta você matar todo mundo senão... Toda aquela coisa. E no fim acabei que aquilo ficava muito mais do que a ideia central da atividade que era mostrar as adaptações evolutivas ne. E no fim eu gostei de fazer aquilo, porque era um... era um... Parênteses ne, que valia muito mais pras pessoas, principalmente, quando vinha uma escola mais do interior assim. Valia muito mais aquilo do que atividade... Tipo pra vida cotidiana deles. Do que pela atividade... Vamos falar sobre evolução. Caia muito mais pra eles, falar é... Ver tipo ah, "não adianta você matar todas as cobras, senão vai vir um monte de rato, ou senão tipo, ah é... Não adianta você ficar cutucando a cobra, senão ela vai te picar e você corre o risco dela ser venenosa ou não. Muito difícil de separar as venenosas, das não venenosas. E aquilo, acho, que ficava muito mais. Eu via isso até como feedback na aula deles ne. Porque eles sempre falam: "Não, porque um tio meu foi picado e não sei o que..." Ficava muito mais pra eles como algo que eles iam usar de útil na vida deles do que ah... Evolução.

Turno 23: [Entrevistador]: Entendi. Legal. Pra você, qual é o objetivo da EB? 
Turno 24: [Mediador N4]: Objetivo da EB? É... Ensinar de uma maneira... Ensinar as mesmas coisas que eles poderiam aprender na sala de aula só que de uma maneira diferente. E, portanto, essa... Esse diferencial, de não estar na sala lendo livro, isso torna eles mais propensos a aprender ou a... Principalmente, acho que isso se enquadra mais no caso de criança mais nova. Eles divertindo, enquanto eles aprendem, eles podem associar essa parte boa de brincar onde... Ou de mexer com as coisas com o aprender. Isso pode fazer com que no futuro eles estejam mais é... Abertos a aprender. Isso é o que eu acho que é o objetivo da EB. Propiciar essa diferença e, ao mesmo tempo, essa... É... Criar esse sentimento bom de aprender algo. Acho que esse é o objetivo.

Turno 25: [Entrevistador]: E pra você, quais são os pontos fortes e fracos da EB?

Turno 26: [Mediador N4]: Tá. Os pontos... O ponto forte da EB é porque... É que a gente sempre repensa as coisas, a todo momento. Tipo, por exemplo, a cada visita a gente pensa, principalmente no caso de atividades novas ne. A gente pensa: "ah, mas isso foi bom, isso foi ruim. Ah, vamos contar isso, vamos não sei o que, vamos..." E também da dentro dessa mentalidade de repensar, mas toda hora a gente busca marcar alguma coisa com uma das professoras daqui mais, por exemplo, a Alessandra ou a Bia que tão mais voltadas pra educação. Marcar uma coisa pra elas, pra darem um papinho sobre Educação Não Formal, é... Tem esse sentimento constante de ficar se reinventando. Agora, um ponto negativo. Eu não sei. Mas eu diria que, às vezes... É... sei lá. A EB tem alguns vícios em que ela... Ao mesmo tempo em que ela se mostra é... Permissiva pra tentar coisas novas em relação as atividades, ela, às vezes, não quer mudar a estrutura dela. Por exemplo, um pouco antes de eu sair tinha... Teve reuniões gerais em que a gente propôs reinventar o sistema de manutenções e tal. E ai o pessoal não quis mudar. Simplesmente porque ah, não vai dar certo. Tipo, não quis nem tentar. E ai... Eu senti isso pô, mas se vocês querem experimentar nas atividades, não querem experimentar na estrutura do negócio ne? Então, tem uma certa rigidez assim. E isso em parte é porque, acho que o pessoal cria as hierarquias baseada em que é bolsista e quem não é. Tipo, as pessoas que são bolsistas são mais ouvidas na reunião. Eu percebi isso assim. Por mais que esse não tenha sido o intuito, inclusive os bolsistas vivem falando que isso não procede, o pessoal não tá nem aí. Eles criam essa hierarquização na cabeça deles.

Turno 27: [Entrevistador]: Você acha que os bolsistas, então, eles estão num patamar acima do que aqueles que são voluntários?

Turno 28: [Mediador N4]: Então, não é que eles estão num patamar acima. O pessoal que não é bolsista bota eles lá, entendeu? Tipo, com o tempo, como eles vão fazendo mais coisas, 
eles estão mais por dentro, eu acho que acaba criando esse negócio de que, mesmo que eles não queiram, eles são botados como... Numa hierarquia, pra cima assim, entendeu? E ai, tipo exemplo, é... E também esse negócio também acontece com quem tá muito tempo. O mediador V1 uma vez me comentou isso. Que só pelo fato de ele estar lá na EB há 4, 5 anos, ele era mais ouvido. E por mais que ele faça uma besteira, todo mundo ia ouvir ele. Só porque é velho. Entendeu? (risos). Então, claro que isso é meio que inerente a EB ne. Das pessoas, mas... Esse, eu acho que esse é o maior problema de lá. De ficar dando é... Hierarquizando demais as coisas, no fim a opinião pessoal de um acaba sobressaindo sobre o que a gente deveria ou não tentar.

Turno 29: [Entrevistador]: Entendi. E... Quais são os pontos fortes que você enxerga em si que contribuiu, na época que você estava participando na EB? Pontos fortes em você? Qualidades...

Turno 30: [Mediador N4]: Ah, eu tentava ser proativo. (risos) Eu tentei. Claro que, às vezes, tem aqueles dias que você tá de saco cheio (risos) e não faz nada, mas eu tentei ser bastante na época em que eu tava. Afinal, tipo, esse negócio ai do peçonhentos, nem tinha, nem me pediram e eu fui lá e fiz. É, antes de eu sair também, tinha pouca que sabia fazer a atividade de peçonhentos. Eu fui lá, montei uns power points e fiz uma apresentação de conteúdo é... Conteúdo mesmo teórico pra apresentar em peçonhentos. E alguém tomar as rédeas e, por exemplo, me substituir como uma pessoa que mais entende de peçonhentos da $\mathrm{EB}$, entendeu?

Turno 31: [Entrevistador]: Legal.

Turno 32: [Mediador N4]: Tem... Eu criei esse negócio de: "ah, eu vou passar isso".

Turno 33: [Entrevistador]: E... Você acha que trabalhar na EB te ajudou na formação profissional?

Turno 34: [Mediador N4]: Ah, sim.

Turno 35: [Entrevistador]: Por quê?

Turno 36: [Mediador N4]: Uma, eu aprendi a criar jogo de cintura, principalmente, com criança mais nova. Que, às vezes, eu falava, falava, falava e você via que eles não te entendiam. Ai você tem que repensar o que você disse.. É... Você tem também que... Uma coisa que também foi boa, foi o lance de falar em público ne, eu fiquei menos tímido. É... Mas eu acho que a maior contribuição foi mesmo nesse jogo de cintura. Se não quando você fala uma coisa nada a ver e ai você precisa reescrever tudo o que você tinha pensado mentalmente pra compensar isso e refazer. É... acho que isso ajudou bastante assim.

Turno 37: [Entrevistador]: Legal. Por que você saiu da EB? 
Turno 38: [Mediador N4]: Sai por duas coisas. Uma porque... Ia começar a apertar meu horário. Eu decidi, por isso, "ah, eu vou ficar mais no estudo em... No que eu quero, que é seguir em ciência mesmo. Por mais que eu tenha adorado a EB, eu gosto muito de educação, eu gosto de ciência (risos). Ai, eu decidi focar mais nisso a partir de agora e eu no fundo eu tinha refletido que se eu fizesse um bom esforço eu conseguiria continuar na EB, só que ai eu saia fazendo isso em detrimento do que eu poderia fazer, largando a EB e ao mesmo tempo eu tava já naquele negócio de... Eu tava meio crica já com esse negócio que eu apontei de que a EB tem essas rigidezes ai e eu já tava começando a ficar cansado disso. De pô, fulano...

Turno 39: [Entrevistador]: E por que você não quis tentar ser bolsista? Como isso funciona?

Turno 40: [Mediador N4]: Então, num momento eu quis, mas eu não passei na entrevista e depois dessa primeira tentativa eu não tentei mais ser bolsista porque eu fiquei "ah, dane-se". Vou ficar aqui na minha.

Turno 41: [Entrevistador]: Quem faz a entrevista?

Turno 42: [Mediador N4]: Os bolsistas.

Turno 43: [Entrevistador]: Os bolsistas antigos entrevistam os novos?

Turno 44: [Mediador N4]: Isso. E ai, é... O pouco que eu sei de como isso acontece é que eles procuram... Eles têm perfis, ne, de pessoas. Por exemplo, precisa de uma pessoa sistemática pra ser a pessoa que vai cuidar do patrimônio, entendeu? Eles vão vindo por perfis de pessoa ai se sai uma pessoa de patrimônio, tem que ter uma pessoa com mesmo perfil que ela. Mas... Eu não sei direito (risos).

Turno 45: [Entrevistador]: Entendi.

Turno 46: [Mediador N4]: Afinal quem faz os critérios são eles (risos).

Turno 47: [Entrevistador]: Entendi. Tá fazendo alguma coisa de iniciação científica?

Turno 48: [Mediador N4]: Ainda não, mas eu tô falando com os professores. Eu tô com uns dois e eu tô tentando fazer os meus caminhos... O meu caminho com um dos dois.

Turno 49: [Entrevistador]: Tem vontade de voltar pra EB?

Turno 50: [Mediador N4]: Olha... No futuro visível que é um ano, um ano e meio não. Mas... Quem sabe. Principalmente porque eu tô querendo ir pro Ciência sem Fronteiras ne. E ai não dá pra planejar muito ne.

Turno 51: [Entrevistador]: Entendi.

Turno 52: [Mediador N4]: Mas... Por enquanto, num ano e meio, assim, eu acho que não.

Turno 53: [Entrevistador]: Legal. Tem alguma coisa que você queira acrescentar sobre a Estação Biologia? Sobre a sua experiência lá? 
Turno 54: [Mediador N4]: Hum... É... Calma. Eu tinha pensado em uma coisa no meio da entrevista e agora sumiu (risos). É...

Turno 55: [Entrevistador]: Você acha que outras pessoas que são voluntárias, elas sentem essa mesma... Essa mesma coisa que você colocou aqui dessa hierarquização?

Turno 56: [Mediador N4]: Então, o que eu vejo em muita gente é que eles não percebem que eles estão fazendo isso. Tipo, por exemplo, é comum todo mundo esperar o bolsista da comissão chegar pra botar ordem na casa, tal. Sendo que isso não tinha nada a ver. As pessoas esperavam, porque esperavam. E ai, tipo exemplo, se você tinha alguém que era um bolsista que ele era responsável e chegava atrasado, a comissão começava atrasada. E ai, as pessoas não percebiam isso, entendeu? Elas estavam só indo no fluxo e... Tava inconsciente. E ai você não chega em ninguém e fala "ou, você tá sendo bobo" (risos). É... você não... Ai, eu notei que isso tá muito internalizado em algumas pessoas, mas... Não sei se é todo mundo que percebe. Apesar de, inclusive, os próprios bolsistas falarem isso nas reuniões, principalmente ne. Que "não, gente, a gente não é patrão de ninguém, você tem que tirar isso da cabeça". O pessoal, tava intrínseco já no pensamento deles, entendeu?

Turno 57: [Entrevistador]: Aham.

Turno 58: [Mediador N4]: Eles... Ai, isso foi uma das coisas. Eu cansei disso. "Ah, eu não vou me sacrificar, pra continuar nisso" (risos). Mas... Principalmente, porque eu tive azar, no meu último semestre eu fui a comissão, foi a... O horário que tinha menos visitas, ne. Então, era o horário que mais tinha comissão, mais ficar debatendo, mais vendo isso. E sem as visitas pra aliviar esse estresse todo. Ai, eu cansei. Não, não chega. É... Uma coisa que, talvez, eu não tenha... Eu gostaria de ter conseguido na $E B$, mas eu não consegui, acho que foi até por falta de oportunidade disso. Foi que eu não aprendi a fazer um link emocional com a pessoa que você tá passando o conteúdo. Isso eu vi que é muito importante, por exemplo, nessa própria visita que eu tinha falado, que tinha um moleque pirralho... Por mais que, eu tentei explicar pra ele "não olha como são legais". Ele não tava nem ai. Ai um outro mediador pegou, ele... Deu... Fez o menino dar um giro assim no ar, ele ficou hiper feliz e ai, do nada ele começou a se comportar porque... Ele sabia o jeito de lidar com cada perfil de criança. Isso eu não ganhei assim. Principalmente, porque eu peguei maior parte das minhas visitas foram de Ensino Médio ne. Então, não tinha muito o que você ganhar com isso. Ai... Mas eu queria ter conseguido essa... Essa experiência até ne. Não, não digo nem só o jogo de cintura, mas tipo, saber identificar o perfil de uma pessoa e saber como trabalhar o conteúdo com esses 
tipos diferentes de pessoa. Eu aprendi de uma forma geralzona que a média ai. A média não diz nada.

Turno 59: [Entrevistador]: Entendi..

Turno 60: [Mediador N4]: Então, enfim, acho que fiquei bem deficiente nisso. Queria ter aprendido isso.

Turno 61: [Entrevistador]: Entendi. Mais alguma coisa?.

Turno 62: [Mediador N4]: Acho que não (risos).

Turno 63: [Entrevistador]: Acho que é isso.

Turno 64: [Mediador N4]: Beleza.

Turno 65: [Entrevistador]: Obrigada. 


\author{
ANEXO B - Roteiros das Entrevistas \\ Roteiro para $1^{\text {a }}$ Entrevista - Mediadores Estação Biologia \\ Pesquisadora: Luana Biasutti \\ Orientadora: Alessandra Bizerra
}

Data da entrevista:

1. Nome:

2. Idade:

3. Quanto tempo está na Biologia?

4. Por que escolheu fazer graduação em Biologia?

5. Por que escolheu fazer Biologia na USP?

6. Faz licenciatura e/ou bacharelado? Se só faz licenciatura ou bacharelado, por quê?

7. Qual área da biologia mais te interessa (ou gostaria de atuar)?

8. Trabalha ou trabalhou em algo antes de entrar na USP? Algo vinculado à educação?

9. Quanto tempo está na EB?

10. Por que decidiu entrar na EB? (O que motivou entrar na EB?) E o que motivou continuar (veteranos)?

11. Qual sua função na EB?

12. Com que frequência vem à EB? (Qual sua escala?)

13. De quantas visitas já participou? O que achou dessas experiências?

14. Qual atividade que mais gosta da EB?

15. Qual público prefere atender: EM ou EF?

16. Para você, qual o objetivo da EB? 
17. Enxerga a EB como um espaço de Educação Não Formal? Por quê?

18. No seu ponto de vista, quais são os pontos fortes e fracos da EB?

19. Quais são os pontos fortes que você enxerga em si mesmo que contribuiria (contribui) com a EB?

20. Acredita que a EB possa ajudar na sua formação profissional? Por quê?

21. Gosta de trabalhar como mediador? Pensa em continuar nessa área?

22. Participa ou pretende participar da elaboração das atividades da EB?

23. Como você acha que contribuiria para a elaboração das atividades (pontos fortes do mediador)?

24. Como você se vê na EB daqui a 6 meses?

\author{
Roteiro para $2^{\mathrm{a}}$ Entrevista- Mediadores Estação Biologia \\ Pesquisadora: Luana Biasutti \\ Orientadora: Alessandra Bizerra
}

Data da entrevista:

25. Nome:

26. Quanto tempo está na EB?

27. Por que decidiu entrar na EB? (O que motivou entrar na EB?) E o que motivou continuar (veteranos)?

28. Qual sua função na EB? Ou Quais são as funções de um mediador na EB?

29. Com que frequência vem à EB? (Qual sua escala?)

30. De quantas visitas já participou? O que achou dessas experiências?

31. Qual atividade que mais gosta da EB? Costuma ou prefere apresenta-las durante as visitas? 
32. Para você, qual o objetivo da EB?

33. No seu ponto de vista, quais são os pontos fortes e fracos da EB?

34. Quais são os pontos fortes que você enxerga em si mesmo que contribuiria (contribui) com a EB?

Perguntas extras relacionadas às visitas:

35. Como é escolhido o que cada mediador irá fazer durante a visita?

36. O que eles entendem por engajamento?

37. Quando se pode considerar que um mediador está engajado na EB?

38. O que torna um mediador mais engajado do que o outro para eles? 


\section{ANEXO C - Modelo das Autorizações}

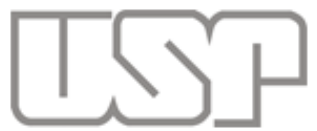

engajamento mútuo como elemento formativo de mediadores de espaços de educação não formal' a realizar coleta de imagens, áudios e depoimentos que se façam necessários, sem quaisquer ônus financeiros a nenhuma das partes, para fins unicamente de pesquisa. Salientando que o foco dessa pesquisa são os mediadores da Estação Biologia e que a imagem do sujeito de pesquisa será preservada e utilizada somente para análise do objetivo proposto pelo projeto de pesquisa.

\section{TERMO DE AUTORIZAÇÃO DE USO DE IMAGEM, ÁUDIO E DEPOIMENTOS}

$\mathrm{Eu}$ CPF

RG estudante do curso de Ciências Biológicas da Universidade de São Paulo, autorizo, através do presente termo, a pesquisadora Luana Dalmaschio Biasutti, $n^{\circ}$ USP 7058925 , do projeto de pesquisa intitulado "O engajamento mútuo como elemento formativo de mediadores em espaços de educação não formal a realizar coleta de imagens, áudios e depoimentos que se façam necessários, sem quaisquer ônus financeiros a nenhuma das partes, para fins unicamente de pesquisa. Salientando que o foco dessa pesquisa são os mediadores da Estação Biologia e que a imagem do sujeito de pesquisa será preservada e utilizada somente para análise do objetivo proposto pelo projeto de pesquisa. 
